\title{
PALEOCLIMATE CONSTRAINTS ON TERRESTRIAL HYDROCLIMATE, SILICATE WEATHERING, AND THE CARBON CYCLE
}

\author{
A DISSERTATION \\ SUBMITTED TO THE DEPARTMENT OF EARTH SYSTEM SCIENCE \\ AND THE COMMITTEE ON GRADUATE STUDIES \\ OF STANFORD UNIVERSITY \\ IN PARTIAL FULFILLMENT OF THE REQUIREMENTS \\ FOR THE DEGREE OF \\ DOCTOR OF PHILOSOPHY
}

DANIEL ENRIQUE IBARRA

APRIL 2018 
(C) 2018 by Daniel Enrique Ibarra. All Rights Reserved.

Re-distributed by Stanford University under license with the author.

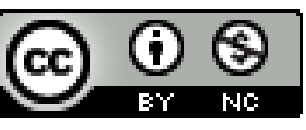

This work is licensed under a Creative Commons AttributionNoncommercial 3.0 United States License.

http://creativecommons.org/licenses/by-nc/3.0/us/

This dissertation is online at: http://purl.stanford.edu/bs206bw9349

Includes supplemental files:

1. Chapter 1 Lake Model Example Code (Ibarra_Chapter1_ExampleCode.zip)

2. Chapter 2 Lake Model Example Code (Ibarra_Chapter2_ExampleCode.R)

3. Chapter 2 Compilation Tables (Ibarra_Chapter2_Tables.xlsx)

4. Chapter 3 Concentration-Discharge Example Code (Ibarra_Chapter3_ExampleCode.zip)

5. Chapter 3 Results Tables (Ibarra_Chapter3_Tables.xlsx)

6. Chapter 4 Data Tables (Ibarra_Chapter4_Tables.xlsx) 
I certify that I have read this dissertation and that, in my opinion, it is fully adequate in scope and quality as a dissertation for the degree of Doctor of Philosophy.

Page Chamberlain, Primary Adviser

I certify that I have read this dissertation and that, in my opinion, it is fully adequate in scope and quality as a dissertation for the degree of Doctor of Philosophy.

Scott Fendorf

I certify that I have read this dissertation and that, in my opinion, it is fully adequate in scope and quality as a dissertation for the degree of Doctor of Philosophy.

Kate Maher

Approved for the Stanford University Committee on Graduate Studies.

Patricia J. Gumport, Vice Provost for Graduate Education

This signature page was generated electronically upon submission of this dissertation in electronic format. An original signed hard copy of the signature page is on file in University Archives. 


\begin{abstract}
Maintenance of a habitable planet requires connections and balance among Earth's biogeochemical cycles. Further, the strength of the feedbacks and couplings determines the stability of conditions in the surface climate system necessary for the evolution of life. Records of Earth's past climate, paleoclimate records, provide constraints beyond the reach of the instrumental record on the directionality, strength and co-evolution of key Earth system cycles. This includes the geologic carbon cycle, the water cycle and the planet's energy balance.

Crucially, the geography, topography and lithology of Earth's continents have two important features that are the focus of this dissertation. First, the continents provide boundary conditions that determine global circulation and hydroclimate patterns that couple Earth's water and carbon cycles (Chapters 1 and 2). Second, the land surface provides a stabilizing negative feedback in the form of silicate weathering fluxes (Chapters 3 and 4, and Appendix E), balancing the long-term carbon cycle through alkalinity and solute delivery to the oceans, and subsequent carbonate burial. In this dissertation I use data, observations and modeling to place mechanistic constraints on how interactions between Earth's surface and long-term biogeochemical cycles maintain balance and habitable conditions in our climate system conducive for the evolution of life.
\end{abstract}

Fundamental to understanding our climate system is predicting the anticipated sign of terrestrial hydroclimate change during periods of climatic change. To this end I have investigated the regional response of hydroclimate change using paleoclimate records from mid-latitude lake systems. First, in Chapter 1, I have developed an inverse 
model to quantify how a mid-latitude lake system in Asia, the Songliao Basin, responded to a transient warming event during the Cretaceous. This model was also applied to a Holocene ostracod record from Lake Miragoane, Haiti. Second, in Chapter 2, I compile spatial distributions and size estimates of pluvial lake systems in western North America during the Pliocene-Pleistocene. By imposing mass and energy balance constraints (sensu Budyko) I forward modeled lake area distributions to demonstrate that now-arid western North America was wetter during both past colder and warmer periods during the Pliocene-Pleistocene, a result not predicted for future warming scenarios. Geologic observations primarily suggest wetter conditions globally during warmer-than-present periods. Importantly, this observation is a requirement for the operation of the stabilizing negative feedback between silicate weathering and climate.

Understanding the factors that control silicate weathering rates is fundamental to constraining the evolution of Earth's carbon cycle over geologic timescales. One challenge for reconstructing past weathering rates is determining the reactivity of Earth's surface. In Chapter 3 I have quantified the reactivity of modern basalt and granite catchments using a process-based solute production model and concentration-discharge weathering relationships. This approach provides mechanisms that link runoff (i.e., terrestrial hydroclimate changes that were the focus of Chapters 1 and 2) with the distribution of global sub-aerial silicate lithologies. In Chapter 4 I utilize an emerging metal isotope system, lithium isotopes, to investigate the terrestrial weathering response to a large perturbation in the carbon cycle during the Cretaceous. We determine that the background-state of the Cretaceous weathering system was more congruent and, hence, more sensitive to perturbations in the carbon cycle than during the Neogene. Finally, in 
Appendix E I have quantified how step-wise geologic evolution of land plants strengthened the silicate weathering feedback over the Phanerozoic. I have developed a new reactive transport framework for evaluating the relative plant-controlled roles of hydrologic versus thermodynamic mechanisms that influence the coupling between the water cycle and silicate weathering fluxes on a continental scale.

The results described in this dissertation constrain links between two connected portions of the exogenic Earth system. I have provided constraints for how the land surface records past changes in regional atmospheric circulation patterns, as well as regional water and energy balances. Further, using reactive transport modeling, I have placed new constraints on the role of plants and lithology in determining the coupling between terrestrial hydroclimate and weathering. Collectively these results suggest that the surface Earth system, our planet's fluid envelope, has been progressively tuned by the advent of continents and the evolution of life. 


\section{ACKNOWLEDGEMENTS}

Having spent a decade at Stanford University I have many individuals to thank for their mentorship, support, inspiration and encouragement over the course of my undergraduate and graduate scientific training. The people of Stanford are what make it such a wonderful, dynamic and enriching educational institution. I am honored to have spent so much time interacting with the many talented scientists at Stanford.

I owe much of where I am today to my $\mathrm{PhD}$ advisor, C. Page Chamberlain, who has unconditionally supported me throughout my training to become a research scientist. I met Page as a rising sophomore on his field course in the Greater Yellowstone Area. This experience sparked an interest in the geosciences that eventually resulted in my pursuit of geochemistry. Page lives life to the fullest in an inspiring way. Whether engaged in scientific inquiry, hunting ungulates, musical expression, or carrying out fieldwork, Page always brings an animated and unique approach to problem solving. I will look fondly back on the time spent with Page carrying out research, teaching in the field, and traveling to remote corners of the world for fieldwork.

Kate Maher, my BS and MS advisor, has been an integral part of my scientific training at Stanford. I joined Kate's research group as a junior and, along with Jessica Oster, she quickly immersed me into the wonderful world of isotope geochemistry and paleoclimate. Kate was an incredibly patient mentor, allowing me space to find my scientific voice, and providing me the resources to carry out science. With a steady hand she guided me through the publication process for the first time and spent many long hours teaching me fundamental geochemistry concepts. Collaborating with Kate on many different scientific problems over my time at Stanford has been truly inspirational. 
I am extremely grateful to the faculty on my PhD committee: 1) Stephan Graham has been a driving force throughout my studies at Stanford, facilitating fieldwork and sample collection in China, and setting up collaborations for me via his broad research network; 2) Scott Fendorf, has been a steadfast supporter, mentor and educator since I took his soil science course as an undergraduate; 3) Jonathan Payne, has provided great insights and detailed comments through the dissertation process; and 4) C. Kevin Boyce, my dissertation defense chair, whom I have had the pleasure of frequently interacting with over the last few years, has inspired new approaches and thinking in my research.

Other faculty members and collaborators at Stanford and at external institutions were integral in my scientific training and contributed directly to the contents of this dissertation. I owe much of my education to the teaching efforts of the faculty, which include: Wendy Mao, Dennis Bird, Karen Casciotti, Elizabeth Miller, Richard Nevle, Gordon Brown, Leif Thomas, Noah Diffenbaugh and Simon Klemperer. I would especially like to thank Wendy Mao and Dennis Bird who have given me advice and mentorship throughout my studies. Jessica Oster (Vanderbilt University), a co-author of Chapter 2, has been one of my closest collaborators, has taught me important lessons in combining creativity and interdisciplinarity, and I look forward to collaborating with her in the years to come. Friedhelm von Blanckenburg (GFZ Potsdam), a co-author of Chapter 4, introduced me to the complexities of metal isotope geochemistry, hosted me for several months at his lab in Germany, and has been integral in developing my geochemical intuition over the past several years through our collaborations.

One of the joys of pursuing my PhD at Stanford has been collaborating with other students on research projects. In our research group I have been honored and inspired to 
work with incredible individuals: Jeremy Caves Rugenstein, Matt Winnick, Hari Mix, Tyler Kukla, Annie Ritch and Yadi Ibarra. I'm thankful to have had the opportunity to do fieldwork, publish papers and collaborate on interesting problems collectively. Jeremy, Hari and Matt challenged me intellectually early in my $\mathrm{PhD}$, supported me immensely throughout my time at Stanford, and provided perspective when things have not turned out as expected. Within the Earth history and geochemistry groups at Stanford I have been grateful to participate in many discussions as part of EHGoS, the Earth History Group of Support, spearheaded initially by Kimberly Lau and Jeremy Caves Rugenstein. Long discussions and debates late into the evenings at Geocastle with Kimberly Lau, Adam Jost, Andres Baresch, Jeremy Caves Rugenstein, Matt Winnick, Hari Mix, Tyler Kukla, Annie Ritch, Mike D’Antonio, Sandra Schachat, Callum Bobb and Tom Boag has spawned many exciting ideas, including some of the modeling results presented in this dissertation and several other ongoing studies.

I am grateful for the mentorship from and collaborations with Aviv Bachan, Kimberly Lau, Andres Baresch (all Stanford, coauthors of Appendix E), Dana Thomas (co-author of Chapter 3 and Appendix E), Jeremy Caves Rugenstein (co-author of Chapters 2-4 and Appendix E), Matthew Winnick (co-author of Chapter 2), Seulgi Moon (UCLA, co-author of Chapter 3), Matt Jones, Brad Sageman (both Northwestern University, co-authors of Chapter 4), Anne Egger (Central Washginton University), Yuan Gao (China University of Geosciences, Beijing), and Jorge Vazquez (USGS, second reader for my M.S. work). None of the geochemistry work carried out in our laboratories happens without the efforts of dedicated laboratory managers Karrie Weaver, Peter Blisniuk, David Mucciarione, Guangchao Li, Juan Lezama Pacheco (all Stanford), 
Geerke Floor and Jan Schuessler (both GFZ Potsdam). Karrie Weaver in the ICP-MS lab has patiently taught me laboratory skills and Peter Blisniuk is always eager to help make measurements happen in the stable isotope facility. I am thankful for the student and administrative support from both the ESS and GS departments over the years, including the efforts of Kristin Tewksbury, Alyssa Ferree, Vanessa Bravo, Robin Maslin, Siegrid Munda, Javier Illueca, Maureen Sullivan, Rebecca Tran, Arlene Abucay and Yvonne Lopez. Additionally, much of my work involved discovering un-digitized maps and doing spatial analyses aided by the Branner Library and geospatial staff, thank you to David Medeiros, Hannah Winkler, Julie Sweetkind-Singer and Jane Ingalls.

Thank you to the extended Chamberlain group past and present, including, Sam Kramer, Christine Cavallo, Elif Tasar, Stephen Spears, Jim Sweeney, Danielle Moragne, Charlie Olson, Will Geier and Susanah Poland, for the late-night jam sessions, comradery and support. I'd also like to thank past and present members of the Maher and Bird groups, Cynthia McClain, Kimberly Lau, Dana Thomas, Joey Nelson, Pablo Garcia del Real, Miguel Cruz, Valerie Rosen, Perach Nuriel, Jennie Druhan, and Callum Bobb, for inspiring me early on and encouraging me to pursue a Ph.D. With fellow colleagues in GS and ESS, Danielle Touma, Ellen Ward, Hannah Joy-Warren, Elsa Ordway, Ginny Selz, Sarah Fakhreddine, Neil Tangri, Heidi Hirsch, David Koweek, Brian Peters, Taylor Martin, Sverre LeRoy, Jared Gooley, James Dennedy-Frank, Emily Cardarelli, Nora Nieminski, Kat Gonzales, Shersingh Tumber-Davila, and Kate Turner, I have enjoyed my time outside exploring the Bay Area, getting together to celebrate milestones and interacting scientifically. I would especially like to thank Danielle Touma for being my fellow GSAC representative and Ellen Ward for being the best office comrade anyone 
could ask for. Special mentions goes to Callum Bobb, whom I have carpooled with from Santa Cruz for almost two years. Cal has become a confidant and challenged me with new ways of thinking about science and life.

Just as important as the academic support has been the personal support I have received from my friends and family along the way. My friends in the Bay Area and beyond have been enormously helpful in maintaining my sanity, providing perspective and providing words of encouragement when research got tough. Thank you to the inspirational Trideuce gang, friends from Montana and Hong Kong, and friends from my undergraduate years: Zach Ming, Kaz Gunning, Krystina Tran, Vincent Chen, Jason Gonzalez, Angela Chu, Chris Geddes, Amanda Lee, Erin Ladd, Andrew Ladd, Ishan Nath, Julia Nath, Cameron Webster, Elif Tasar, Fannie Watkinson, Pedro Gonzalez, Poncie Rutsch, Allison Fink, Rowena Myrans, Autumn Burnes and Brian Louie. From Tahoe ski trips, to friends Christmas parties, to cheering on Stanford football, I have loved spending time with all of you and can't wait for our future adventures together.

My family has been steadfast in their support of my scientific training. I'd like to thank the Lummis family (Patty, John, Jennie and James) for embracing me into their family, teaching me to value the important things in life, and hosting numerous graduate students at their home in Wyoming and letting them do laundry on days off from fieldwork. Special thanks goes to my brother, "hurricane" Eric Ibarra, for always being the fun sibling, teaching me how to tell a story, embracing my science-y quirks and humbling me along the way.

None of this would have happened without the love, support and encouragement from my mom, Diana Ibarra. Seeing her career in environmental engineering and 
sustainability education flourish and impact the lives of many students has been truly inspirational. I'd be remiss not to thank my mom for signing me up for endless science, nature and outdoor activities growing up. Somehow perhaps she knew, before I did, that I would end up an Earth scientist. Thank you also for providing Sarah and me with an endless supply of Asian tea, contact lenses and allergy medicine.

Lastly I owe a huge thank you to my partner and wife Sarah Lummis. You challenge me every day and I'm inspired by your ambitions, passion for marine biology and eagerness to educate others. Thank you also for your love and support throughout the dissertation process. I'm excited to see where your $\mathrm{PhD}$ takes you and excited about seeing where our life together takes us. 


\section{TABLE OF CONTENTS}

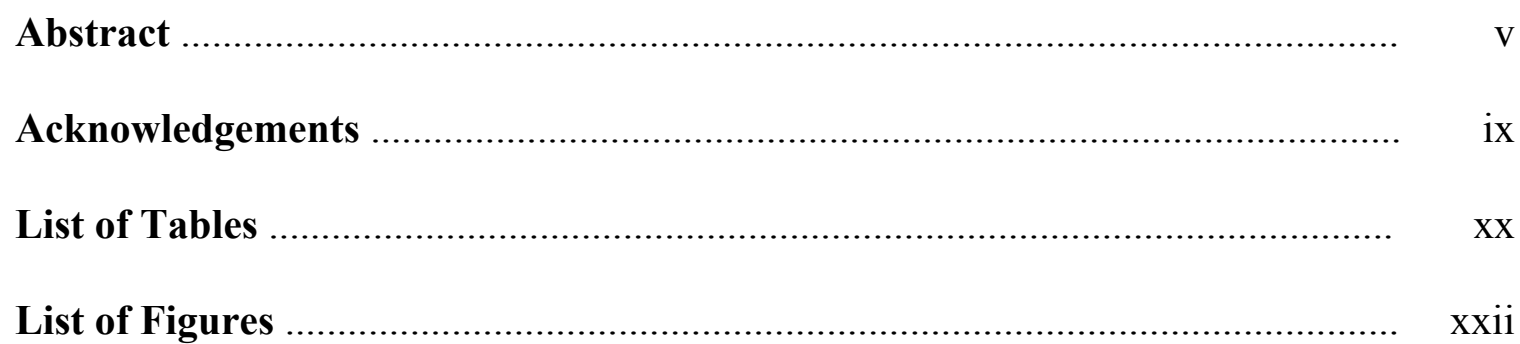

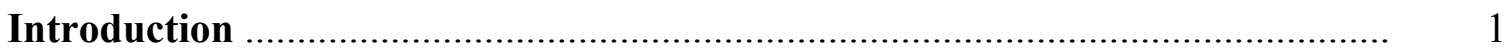

Contribution Statements and Scientific Result Dissemination .................... 8

Introductory References .............................................................. 17

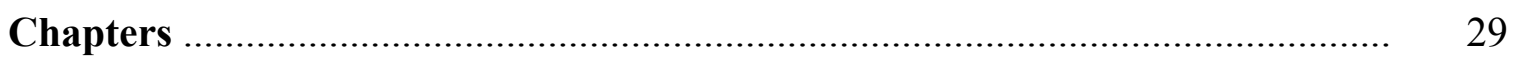

Chapter 1. Quantifying closed-basin lake temperature and hydrology by inversion of oxygen isotope and trace element paleoclimate records (Ibarra and Chamberlain, 2015, American Journal of Science) ............................................... 29

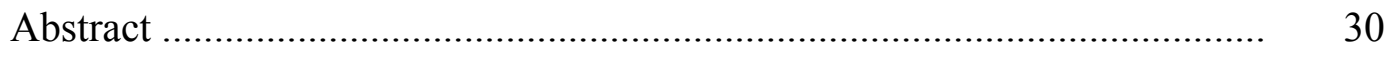

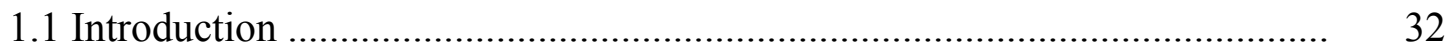

1.2 Model Development ...................................................................... 35

1.3 Example Applications ................................................................. 50

1.4 Limitations and Guidelines ............................................................ 54

1.5 Conclusions and Future Model Refinement ........................................... 56

1.6 Acknowledgements ..................................................................... 59 


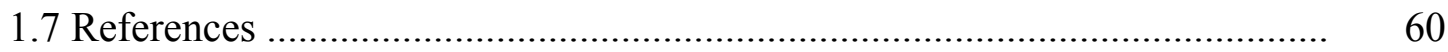

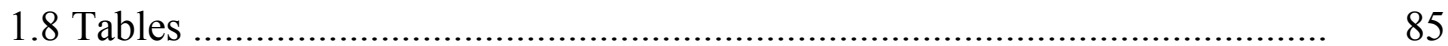

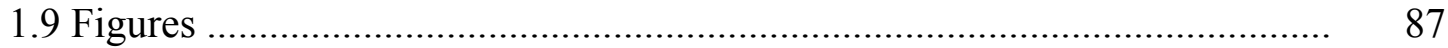

Chapter 2. Warm and cold wet-states in the western United States during the Pliocene-Pleistocene (Ibarra et al., 2018, Geology) ................................................ 91

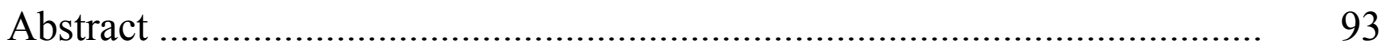

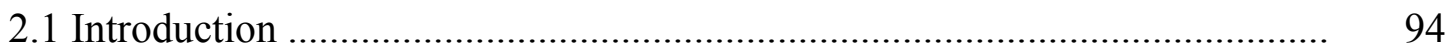

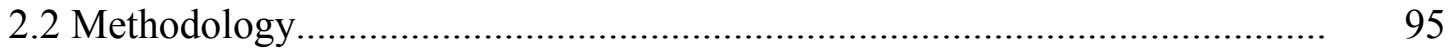

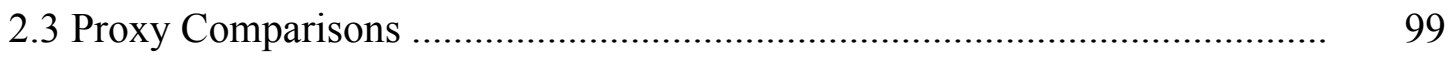

2.4 Hydrologic Modeling .............................................................................. 100

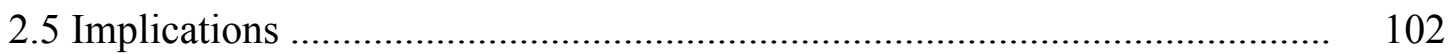

2.6 Acknowledgements ............................................................................... 103

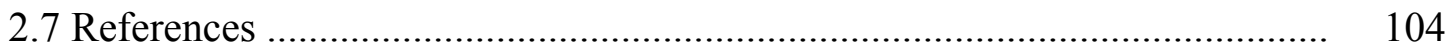

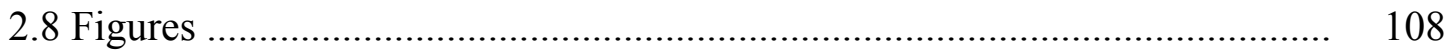

Chapter 3. Concentration-discharge relationships of monolithologic catchments

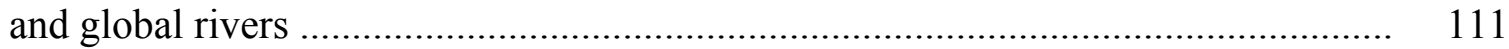

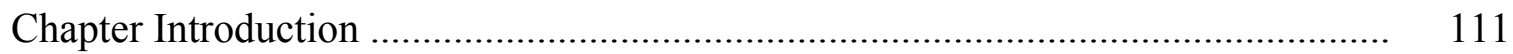

Chapter 3.1 Differential weathering of basaltic and granitic catchments from concentration-discharge relationships (Ibarra et al., 2016, Geochimica et Cosmochimica Acta) ……............................................................................ 113 


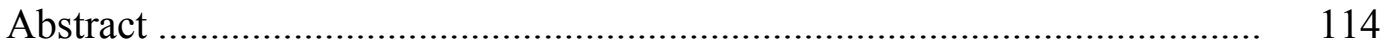

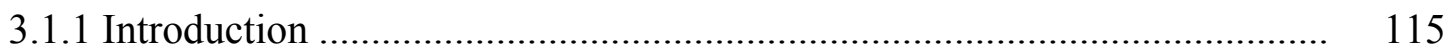

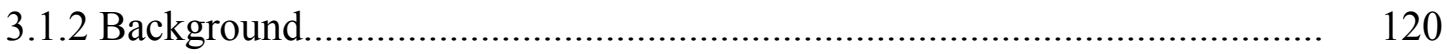

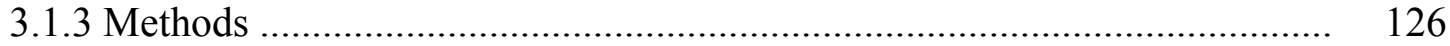

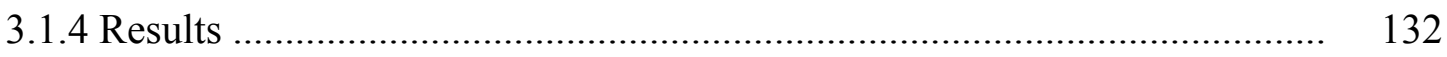

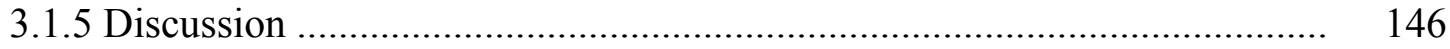

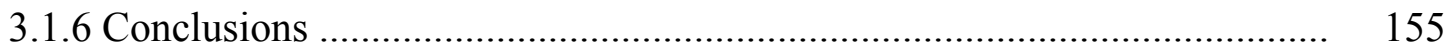

3.1.7 Acknowledgements ............................................................................. 156

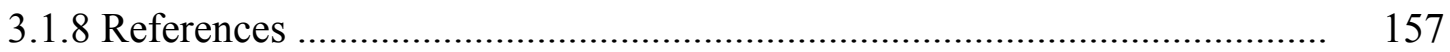

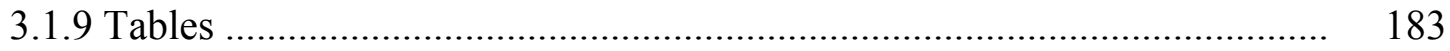

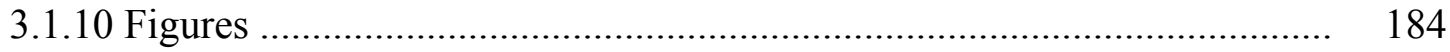

Chapter 3.2 Concentration-discharge patterns of weathering prodcuts from global rivers (Ibarra et al., 2017, Acta Geochimica) …………….................................... 209

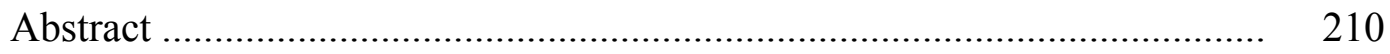

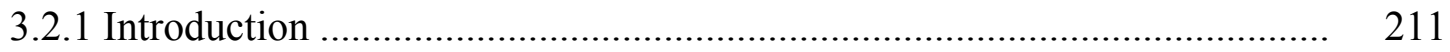

3.2.2 Framework and Methods …………………….................................... 211

3.2.3 Results and Discussion .................................................................... 214

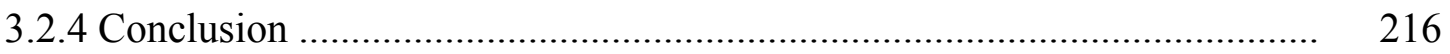

3.2.5 Acknowledgements ....................................................................... 216

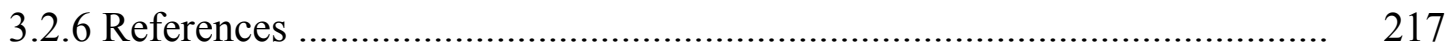

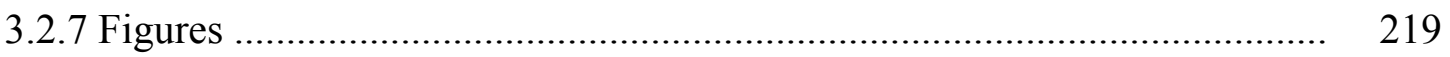


Chapter 4. Quantifying weathering intensity of North America across

Oceanic Anoxic Event 2 (Ibarra et al., In Preparation) ........................................ 223

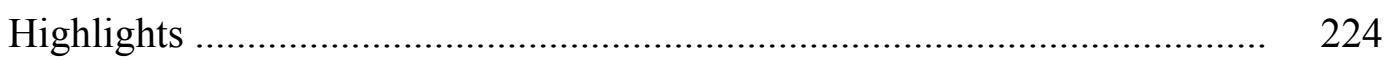

Abstract ................................................................................ 225

4.1 Introduction ................................................................................. 227

4.2 Geologic Materials and Setting ............................................................ 231

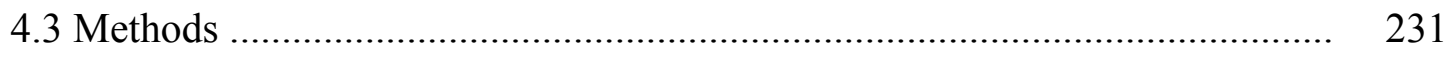

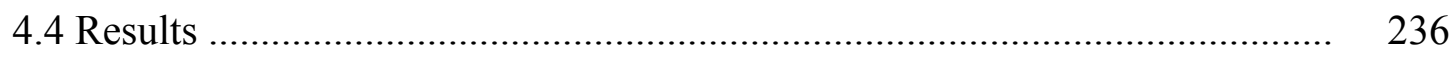

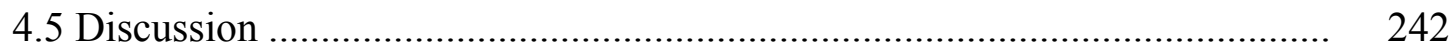

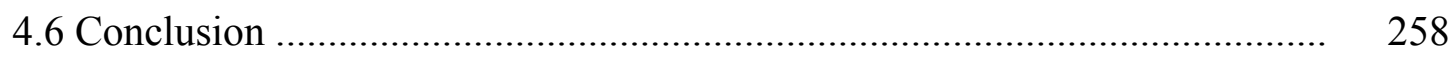

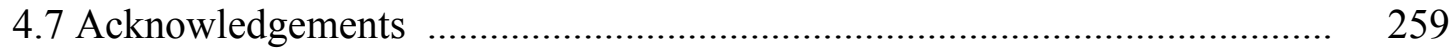

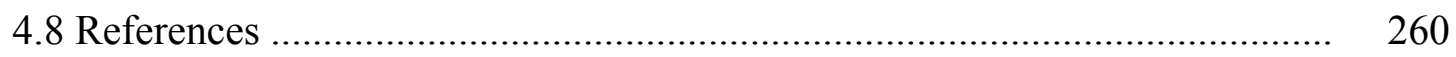

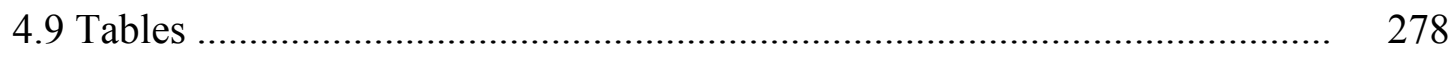

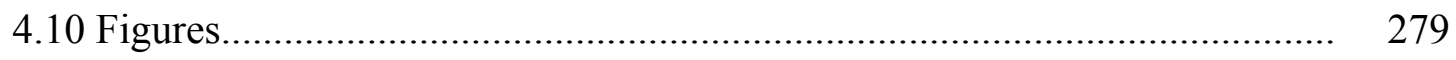

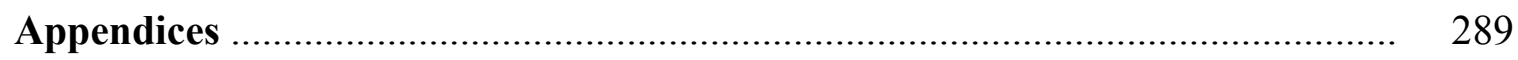

Appendix A. Supplemental Figures for Chapter 1 ........................................... 289

Appendix B. Supplemental Text, Figures and Tables for Chapter 2 .................... 292

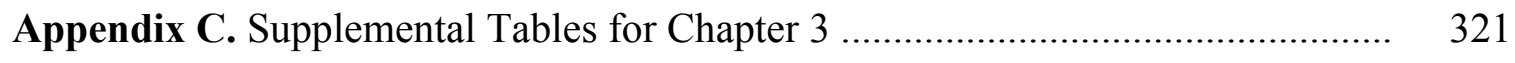

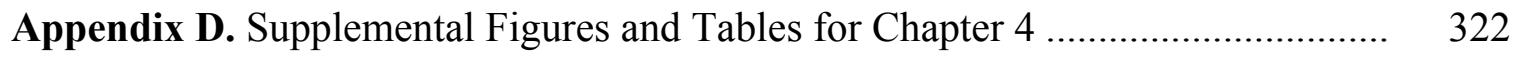


Appendix E. Modeling the consequences of land plant evolution on silicate weathering (Ibarra and others, Accepted, American Journal of Science)

Abstract

E.1 Introduction

E.2 Modeling Framework

E.3 Model Results

E.4 Discussion

E.5 Implications

E.6 Conclusion

E.7 Acknowledgements

E.8 References

E.9 Tables 385

E.10 Figures. 389

E.11 Additional Material 401 


\section{LIST OF TABLES}

\section{Chapter 1}

Table 1. Definition of model parameters for HyBIM as used in the text .................. 85

Table 2. Details of input dataset and input parameters for HyBIM application to

Lake Miragoane and Songliao Basin ................................................................ 86

\section{Chapter 3}

\section{Chapter 3.1}

Table 1. Summary statistics for concentration-runoff fits and flux-weighted data ....

\section{Chapter 4}

Table 1. Aristocrat Angus Core Lithium Isotope, Lithium Concentration and Bulk

Geochemistry Results

\section{Appendix B (Chapter 2)}

Table DR1. Compilation of late Pleistocene lake areas and modern watershed

areas

Table DR2. Area of modern lakes found in terminal watersheds

Table DR3. Compilation of mid-Pliocene lake deposits

Table DR4. Climate models used in this study

Table DR5. Regional fitted Budyko parameters 


\section{Appendix C (Chapter 3)}

\section{Chapter 3.1}

Table A1. Summary of compiled datasets

Tables A2-A8 $\mathrm{SiO}_{2}(\mathrm{aq}), \mathrm{Mg}^{2+}, \mathrm{Ca}^{2+}, \mathrm{Na}^{*}, \mathrm{HCO}_{3}{ }^{-}$, Catio-equivalent, TDS

concentration-runoff results

Table A9. Flux weighted concentrations and $D w$ values

\section{Chapter 3.2}

Table S1. Average concentraiton-runoff pair and full concentration-runoff fitted

parameters

\section{Appendix D (Chapter 4)}

Table S1. Aristocrat Angus core carbon and oxygen isotope data by depth

Table S2. Aristocrat Angus core X-ray diffraction and coulometric results

\section{Appendix E}

Table 1. Definition and units of model variables

Table 2. Variable constraints for input parameters

Table 3. Summary of model results and GEOCARBSULF parameters based on Berner (2006) and Royer and others (2014)

Table A1. Possible combinations of Robin, Neumann, and Dirichlet boundary conditions on the left and right sides 


\section{LIST OF FIGURES}

\section{Chapter 1}

Figure 1. Illustration of evaporation relationships ........................................... 87

Figure 2. Illustration of mixing relationships ................................................. 88

Figure 3. Illustrative Application of HyBIM to Lake Miragoane ........................... 89

Figure 4. Illustrative Application of HyBIM to the Songliao Basin ....................... 90

\section{Chapter 2}

Figure 1. Maps of lakes and hydroclimate-sensitive proxies, western United States 108

Figure 2. Climatic forcing and lake area changes, western United States

109

\section{Chapter 3}

\section{Chapter 3.1}

Figure 1. Location of datasets and conceptual model for concentration-runoff

processes

Figure 2. Framework for evaluating catchment solute production

Figure 3. Illustrative correction of concentration-runoff relationship for non-zero

$\mathrm{C}_{0}$ within the solute production framework

Figure 4. Concentration-runoff fits for catchments

Figure 5. $C_{0}$-corrected concentration-runoff fits and $C_{\max }$ distributions

Figure 6. Flux-weighted concentration pairs 
Figure 7. Concentration-runoff derived maximum concentration $\left(C_{\max }\right)$ vs. water

temperature

Figure 8 . Histograms of saturation indices for select primary and secondary

minerals

Figure 9. Activity diagrams of the smectite-kaolinite system

Figure 10. Concentration-runoff derived Damköhler coefficient $(D w)$ cross-plots ... 200

Figure 11. Concentration-runoff derived Damköhler coefficients $(D w)$ vs. water

temperature

Figure 12. Weathering potential

Figure 13. $\mathrm{SiO}_{2}(\mathrm{aq})$ and $\mathrm{HCO} 3-$ fluxes

Figure 14. Weatherability of basalt vs. granite catchments

206

\section{Chapter 3.2}

Figure 1. Example $C-q$ fits for two global rivers

Figure 2. Results of $C-q$ analysis

\section{Chapter 4}

Figure 1. Chemostratigraphic records from the Aristocrat Angus core spanning the Cenomanian-Turonian (OAE2) interval

Figure 2. Scatter plots of $\delta^{7} \mathrm{Li}_{\text {carb }}$, carbonate $\delta^{18} \mathrm{O}$ and $\delta^{13} \mathrm{C}$, and $\delta^{7} \mathrm{Li}_{\text {res }}$ versus ancillary geochemical measurements 


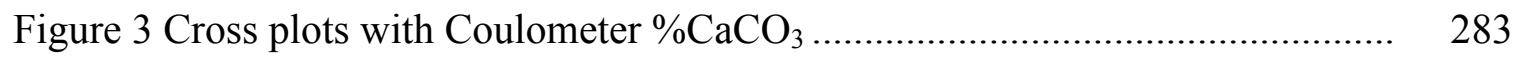

Figure 4. Scatter plots of $\delta^{7} \mathrm{Li}_{\text {carb }}$ versus $\mathrm{Li} / \mathrm{Ca}$ and $\mathrm{Sr} / \mathrm{Ca}$ from OAE 2 interval ........ 284

Figure 5. Illustration of lithium solid-to-dissolved export flux determination and comparison of $\delta^{7} \mathrm{Li}_{\text {res }}$ to modern river sediments .................................................. 285

Figure 6. Selected idealized forward modeling results for OAE2 using the

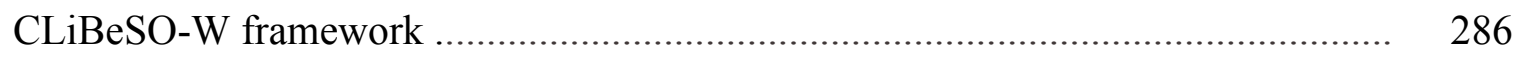

\section{Appendix A (Chapter 1)}

Figure A1. Schematic of HyBIM model structure ………..................................... 289

Figure A2. Annual weighted precipitation $\delta^{18} \mathrm{O}$ and mean annual temperature ........ 291

\section{Appendix B (Chapter 2)}

Figure DR1. Empirical scaling of potential evapotranspiration with surface temperature based on PMIP3, PlioMIP and CMIP5 simulations ............................. 299

Figure DR2. Budyko framework ………...................................................... 300

Figure DR3. Effect of adjusting northern Great Basin lake areas ............................. 301

\section{Appendix D (Chapter 4)}

Figure S1. X-ray diffraction (XRD) patterns ………………………………........ 323

Figure S2. Compilation of strontium isotope datasets across OAE2 …………….... 325

Figure S3. Chemical Index of Alteration Ternary Plot ………............................... 326 


\section{Appendix E}

Figure 1. Schematic of physical set-up of modeling approach ............................. 389

Figure 2. Determination of the effect of plants on water fluxes in Budyko space ..... 390

Figure 3. Results of GWB titration experiments ............................................... 392

Figure 4. Summary of stream concentration data ............................................ 393

Figure 5. Water fluxes simulated by Model 1 ..................................................... 394

Figure 6. Solute fluxes simulated by Model 2 ................................................. 396

Figure 7. Contour plots of weathering concentration (flux weighted) for varying

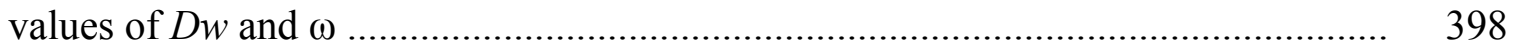

Figure 8. Sensitivity of weathering fluxes (Fsil) to perturbations in climate,

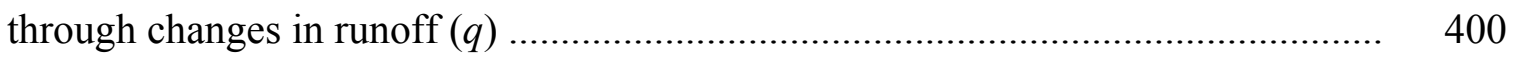

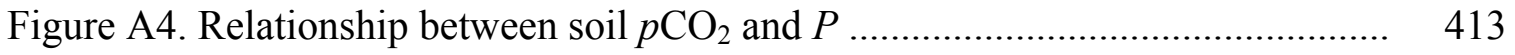

Figure A5. Water and solute fluxes simulated using constant flux to constant flux boundary conditions 
xxvi 


\section{PALEOCLIMATE CONSTRAINTS ON TERRESTRIAL HYDROCLIMATE, SILICATE WEATHERING, AND THE CARBON CYCLE}

\section{INTRODUCTION}

Maintaining habitable conditions in the exogenic Earth system over geologic time requires balance and feedbacks among Earth's biogeochemical cycles (e.g., Urey, 1952; Walker et al., 1981; Berner and Caldeira, 1997; Sleep and Zahnle, 2001; Payne and Kump, 2007; Caves et al., 2016; Bachan et al., 2017). Further, the establishment of subaerial continents, a bimodal hypsometry and an oxidized crust (e.g., Holland, 2002; Hayes and Waldbauer, 2006; Lee et al., 2018), as well as the evolution of life (e.g., Volk, 1987; Knoll, 2003; Sleep and Bird, 2008; Lenton et al., 2014; Boyce and Lee, 2017), has likely stabilized the climate system over geologic time. In this dissertation I have investigated how the geography, topography and lithology of Earth's continents provide boundary conditions and couplings that have progressively tuned and stabilized the Earth surface. The introduction to this dissertation includes: 1) a brief historical perspective on the use of geologic observations to infer past climatic conditions and links to the biosphere; and 2) a discussion of how modern scientific methods, such as advances in isotope geochemistry, have enhanced our ability to quantitatively trace surface Earth system processes over geologic time.

In this dissertation I have sought to investigate the Earth system in the spirit of previous scientific advances by using first-order observations of modern and past terrestrial systems to reconstruct key relationships that influence the co-evolution of 
Earth's biosphere, hydrosphere and lithosphere. Specifically, I have focused on using the water balance recorded by terminal lake systems to reconstruct past changes in hydroclimate (Chapters 1 and 2), and used modeling approaches to investigate the influence of land plants and lithology on silicate weathering fluxes (Chapter 3 and Appendix E). Additionally, I have also investigated the response of terrestrial weathering systems to a large carbon cycle perturbations $\sim 94$ millions years ago in the Cretaceous using new isotope measurements (Chapter 4).

Examination of the landforms and sediments that cover Earth's continents today suggests considerable environmental change over geologic time. While the terrestrial paleoclimate record is fragmentary and incomplete, it provides direct evidence for changes in climate and environmental conditions. Earth scientists have long made observations suggesting dynamic changes in Earth's past climate, and recognized the influence of continental paleogeography and paleotopography in shaping terrestrial environmental conditions. Many of these inferences were established long before the advent of modern mass spectrometers, satellite imagery and coring technologies.

An example pertinent to Chapter 2 of this dissertation (Ibarra et al., 2018) is the geologic exploration of western North America in the $18^{\text {th }}$ and $19^{\text {th }}$ centuries. Early explorers of the American west documented lacustrine shorelines in the terminal basins of the Great Basin (see review by Orme, 2008). Study of these shorelines was subsequently first formally documented in detail by pioneering American geologists, J.W. Powell, G.K. Gilbert and I.C. Russell (e.g., Gilbert, 1875; 1884; 1890; Russell, $1884 ; 1885 ; 1889)$, who in doing so contributed to many classic Earth science concepts such as uniformitarianism, isostasy and diastrophism, and documentation of glacial- 
interglacial cycles (Hunt, 1980; Orme, 2008). These and other Quaternary lakes, and the subsequent documentation of older Cenozoic lake systems in the American west and elsewhere, remain an active avenue of research to this day (e.g., Antevs, 1925; 1948; Hubbs and Miller, 1948; Broecker and Kaufman, 1965; Mifflin and Wheat, 1979; Benson and Paillet, 1989; Carroll and Bohacs, 1999; Hudson and Quade, 2013; Munroe and Laabs, 2013; Pound et al., 2014; Reheis et al., 2014; Ibarra et al., 2014).

Study of Earth's past climate was transformed by the development of isotope measurements and theory following World War II (Urey, 1974; Bigeleisen and Mayer, 1947). The use of isotope systems, as demonstrated in Chapters 1 and 4 of this dissertation, are now commonplace for reconstructing past climate states. Beginning with the measurement of oxygen, hydrogen and carbon isotopes pioneering geochemists, including Harold Urey and Harmon Craig, made the first measurements on mineral and water samples to make paleoenvironmental reconstructions using both marine and terrestrial materials (e.g., Urey, 1947; 1948; Urey et al., 1951; Craig, 1953; Epstein and Mayeda, 1953; Dansgaard, 1954; 1964; Craig and Gordon, 1965). Simultaneously radiometric age determination, primarily using radiocarbon dating, was developed and applied to terrestrial and marine carbonates (e.g., Arnold and Libby, 1951; Libby, 1952; 1954; Antevs, 1955; Broecker and Orr, 1958), allowing for absolute age determinations to test concepts such as Milankovitch theory (Milankovitch, 1920; see review by Berger, 1988). In combination with the expansion of ocean drilling efforts in the subsequent decades these isotope measurements lead to the establishment of seminal marine isotope records covering the Pliocene-Pleistocene (e.g., Hays et al., 1976; Shackleton and Opdyke, 1977; Lisiecki and Raymo, 2005), Mesozoic and Cenozoic (e.g., Zachos et al., 
2001; 2008; Payne et al., 2004; Friedrich et al., 2012), and the entire Phanerozoic (e.g., Veizer et al., 1999; Saltzman and Thomas, 2012). However, a key challenge of paleoclimatology has been to produce spatially resolved and temporally constrained changes in past climate from the more fragmentary terrestrial geologic record. Despite the potential for directly reconstructing atmospheric circulation changes and climate using terrestrial sediments (e.g., Mifflin and Wheat, 1979; Chamberlain et al., 1999; Reheis, 1999; Mulch et al., 2006; Ibarra et al., 2014; Maher et al., 2014; Oster et al., 2015), fundamental knowledge advances from the terrestrial realm have been much more limited thus far.

Reconstructing terrestrial climates in the past may also help refine the predicted impacts of anthropogenic climate change on the terrestrial hydrosphere. This is an important avenue of inquiry because the sensitivity and uncertainty of the terrestrial water cycle to hydrologic cycle intensification under warmer conditions (e.g., Huntington, 2006; Huntington et al., 2018), and the potential impacts of this intensification to human and natural systems, is still actively debated (Hoekstra and Mekonnen, 2012; Scheff and Frierson, 2014; Sherwood and Fu, 2014). For example, a long-standing paradigm proposed that "dry regions get drier and wet regions get wetter" in response to future warming (for further discussion see Greve et al., 2014). However recent historical studies have demonstrated mixed global and regional contrasting responses (e.g., Seager et al., 2007; Dai, 2011; Greve et al., 2014). Similarly, paleoclimate reconstructions have demonstrated a varied regional response to climatic changes over many different timescales caused by changes in moisture delivery mechanisms and recycling over continents (e.g., Munroe and Laabs, 2013; Chamberlain et al., 2014; Ibarra et al., 2014; 
Oster et al., 2015; Caves et al., 2015; 2017). Most significantly, the mid-latitude desert regions, such as the western United States, have been observed to be wetter during both hotter (mid-Pliocene) and colder (Pleistocene glacial periods) periods of Earth's recent history (Reheis, 1999; Winnick et al., 2013; Pound et al., 2014; Oster et al., 2015; Burls and Federov, 2017; Ibarra et al., 2018).

These hydrologic cycle changes at local, regional and continent scales are the focus of Chapters 1 and 2, and Appendix $\mathbf{E}$ of this dissertation (Ibarra and Chamberlain, 2015; Ibarra et al., 2018; Ibarra et al., Accepted). Further, changes in the terrestrial water balance also influence the distribution of the regional to continental scale weathering response (e.g., Gibbs and Kump, 1994; von Blanckenburg et al., 2015), the focus of Chapters 3 and 4, and Appendix $\mathbf{E}$ of this dissertation (Ibarra et al, 2016; Ibarra et al., 2017; Ibarra et al., Accepted). This weathering response to hydroclimate changes directly links the Earth's water and carbon cycles through the silicate weathering negative feedback (Urey, 1952; Walker et al., 1981; Berner and Caldeira, 1997; Kump and Arthur, 1997; Kump et al., 2000; Maher and Chamberlain, 2014).

This dissertation uses the terrestrial geologic record and process-based modeling to understand how feedbacks and forcings have operated over long timescales $(\sim 10,000$ to 100,000 years). Paleoclimate records and modeling approaches that I have used have allowed me to provide constraints beyond the reach of the instrumental record and test hypotheses for how the Earth system operates where the signal to noise is large and the sign of change is unequivocal. The following is a brief summary of the chapter contributions that make up this dissertation. 
1. In Chapter 1 (Ibarra and Chamberlain, 2015, American Journal of Science) I have developed a new inverse modeling framework to quantify how a midlatitude lake system in Asia, the Songliao Basin, responded to a transient warming event during the Cretaceous, Oceanic Anoxic Event 3. This work builds on a previous dataset published by Chamberlain et al. (2013). This model was also applied for illustrative purposes to a previously published Holocene record from Lake Miragoane, Haiti.

2. In Chapter 2 (Ibarra et al., 2018, Geology) I compile spatial distributions and size estimates of pluvial lake systems in western North America during the PliocenePleistocene. I forward modeled lake area distributions to demonstrate that nowarid western North America was wetter during past colder and warmer periods during the Pliocene-Pleistocene, a result not predicted for future warming scenarios. Geologic observations primarily suggest wetter conditions globally during warmer-than-present periods; and importantly, this observation is a requirement for the operation of the stabilizing negative feedback between silicate weathering and climate. This analysis was inspired by feedback received on my previous work on Pleistocene Lake Surprise (California) carried out during my undergraduate and masters in Geological \& Environmental Sciences (Ibarra et al., 2014, Geological Society of America Bulletin).

3. In Chapter 3 (Ibarra et al., 2016, Geochimica et Cosmochimica Acta; Ibarra et al., 2017, Acta Geochimica) I have quantified the reactivity of modern basalt and granite catchments using a process-based solute production model and concentration-discharge weathering relationships. I expand on the process-based 
solute production model from Maher and Chamberlain (2014) by applying their model to concentration-discharge relationships (see also additional prior and subsequent work: Maher et al., 2009; Maher, 2010; 2011; Maher and Druhan, 2014; von Blanckenburg et al., 2015; Wymore et al., 2017; Winnick and Maher, 2018). The approach and framework we use provides process-based mechanisms that link runoff and hydroclimate changes with the distribution of global subaerial silicate lithologies.

4. In Chapter 4 I utilize a metal isotope system, lithium isotopes, to investigate the terrestrial weathering response to a large perturbation in the carbon cycle during the Cretaceous. I determine that the background-state of the Cretaceous weathering system was more congruent and, hence, more sensitive to perturbations in the carbon cycle than during the Neogene.

5. In Appendix E (Ibarra et al., Accepted, American Journal of Science) I have quantified how step-wise geologic evolution of land plants strengthened the silicate weathering feedback over the Phanerozoic. I have developed a new reactive transport framework for evaluating the relative plant-controlled roles of hydrologic versus thermodynamic mechanisms that influence the coupling between the water cycle and silicate weathering fluxes on a continental scale.

In sum, the contributions described herein constrain links between two crucial and connected portions of the exogenic Earth system, the water and carbon cycles. Collectively, they suggest that the exogenic Earth system has been progressively tuned by the advent of continents and the evolution of life. 


\section{Contribution Statements and Scientific Result Dissemination}

The mansucripts presented here reflect the collaborative nature of Earth science research and were not solely undertake by myself. In the following section I describe the contributions to each chapter made by the co-authors for each chapter. Further, I state the publication status of each peer-reviewed manuscript and the peer-reviewers, if self identified during the peer-review process. For each chapter I also describe which scientific conferences the material was presented at prior to and/or subsequent to publication. Following my first-author work I also list all co-authored manuscripts published during my time as $\mathrm{PhD}$ student in Earth System Science (encompassing September 2013 to June 2018).

\section{Chapter 1}

This chapter was published at the American Journal of Science (Ibarra and Chamberlain, 2015). Formal peer-reviews were received from Byron Steinman (University of Minnesota, Duluth) and Jay Quade (University of Arizona). Editor Danny M. Rye (Yale University) handled the peer-review of the manuscript.

C. Page Chamberlain conceived the study and selected the ostracod datasets from previously published literature. Together we co-designed the modeling and mathematical framework, and co-wrote the paper. I implemented the modeling in R, incorporated the Monte Carlo uncertainty propogation and produced all figures. A version of the model presented in this chapter was originally included into NSF Grant EAR-1423967 "Collaborative Research: High-resolution Cretaceous terrestrial climate records of temperature, weathering and hydrologic response to hyperthermals in the Songliao 
Basin, China" (PI: C. Page Chamberlain; co-PIs: Stephan A. Graham, Bradley B.

Sageman, Alan R. Carroll, Bradley S. Singer).

Prior to publication this chapter was presented at the 2014 Geological Society of America Annual Meeting. Following publication this model was updated for the Songliao Basin using new age constraints and presented at the 2015 Geological Society of America Annual Meeting.

\section{Chapter 2}

This chapter was published in Geology (Ibarra et al., 2018). Peer-reviews were received from Alan Carroll (University of Wisconsin, Madison) and three anonymous reviewers. Science Editor Mark C. Quigley (University of Melbourne) handled the peerreview of the manuscript. NSF Grant EAR-1450357 to C. Page Chamberlain funded this chapter.

I designed the study in collaboration with the co-authors, carried out the proxy dataset compilation, conducted the quantitative analysis and wrote the manuscript. Jessica L. Oster helped design the study, contributed to the proxy dataset compilation, and assisted in manuscript preparation and editing. Matthew J. Winnick helped design the study, helped conduct the quantitative analysis, and assisted in manuscript preparation and editing. Jeremy K. Caves Rugenstein helped design the study, helped conduct the quantitative analysis, and assisted in manuscript preparation and editing. Michael P. Byrne helped conduct the quantitative analysis and assisted in manuscript editing. C. Page Chamberlain guided the design the study and assisted in manuscript editing. 
This chapter was presented at the 2015 American Geophysical Union Annual Meeting, and as an invited talk at both the 2016 Geological Society of America Annual Meeting and the 2016 American Geophysical Union Fall Meeting.

\section{Chapter 3}

This chapter was published in two parts, following suggestion by the original reviewers of the first aprt to remove the analysis of the global rivers dataset from the monolithologic datasets. The primary contribution of this chapter was published in Geochimica et Cosmochimica Acta (Ibarra et al., 2016). The formal peer-reviewers were Lee Kump (Pennsylvania State University), Julien Bouchez (Institut de Physique du Globe de Paris) and an anonymous reviewer. The manuscript was handled by Associate Editor Anthony Dosseto (University of Wollongong). The remaining analysis was published and expanded upon in an extended abstract for the $11^{\text {th }}$ Symposium of the Geochemistry of the Earth's Surface in Acta Geochimica (Ibarra et al., 2017). This chapter was primarily funded by NSF CAREER Grant EAR-1254156 to Kate Maher, and was also supported during a visit to UCLA to visit co-author Seulgi Moon by the California Alliance Research Exchange program NSF HRD-1306595 to C. Page Chamberlain.

I co-designed the study, compiled the monolithologic catchment datasets, carried out the bulk of the quantitative analysis, produced all figures, and wrote the manuscript. Jeremy K. Caves helped design the study, carry out the analysis and wrote portions of the manuscript. Seulgi Moon provided the global rivers dataset, which were originally compiled in Moon et al. (2014), helped with the quantitative analysis, and edited the 
manuscript. Dana L. Thomas helped carry out the quantitative analysis and thermodynamic calculations, co-designed several of the figures, and edited the manuscript. Jens Hartmann provided additional monolithologic catchment datasets and edited the manuscript. C. Page Chamberlain helped design the study, edited the manuscript and provided editorial guidance. Kate Maher co-designed the study, provided quantitative analysis tools, wrote portions of the manuscript, and provided editorial guidance.

Components of this chapter were presented at the 2014 American Geophysical Union Fall Meeting, a Critical Zone Observatory Workshop at University of New Hampshire in 2015, the $11^{\text {th }}$ Symposium of the Geochemistry of the Earth's Surface (GES-11) in Guiyang, China in 2017, and as an invited talk at the 2017 American Geophysical Union Fall Meeting.

\section{Chapter 4}

This chapter is being prepared for submission. I co-designed the study, wrote the manuscript, carried out the lithium isotope and trace metal concentration measurements, XRD measurements and co-developed the modeling framework. Matthew M. Jones selected the samples from the Aristocrat Angus core, carried out the weight percent carbonate, organic content analyses, measured the carbonate oxygen and carbon isotopes, re-calibrated the depth and age model for the core, and helped design the study. Geerke Floor helped carry out the lithium isotope and trace metal concentration measurements. Jeremy K. Caves Rugenstin helped developed the modeling framework. Bradley B. Sageman provided access to the samples from the Aristocrat Angus core and guided the 
study design. Stephan A. Graham co-funded the project, and guided the study design. Friedhelm von Blanckenburg provided funding and facilities for the lithium isotope measurements, and helped conceive and design the study. C. Page Chamberlain helped conceive and design the study, co-funded the project and helped with dataset interpretation. This paper was part of a series of collaborative projects between Northwestern University and Stanford University that also involved the publication of an Oceanic Anoxic Event 3 record from the Songliao Basin, China (Jones et al., 2018).

NSF Grants EAR-1450357 to C. Page Chamberlain and Stephan A. Graham and EAR-1424474 to Bradley B. Sageman funded this chapter. Support for travel to Germany was partially covered by the Stanford EDGE-STEM Fellowship. This work will be presented at the 2018 Goldschmidt Conference.

\section{Appendix $E$}

This appendix manuscript has been accepted to American Journal of Science and is currently being revised. Formal peer-reviews have been received by Nathan Sheldon (University of Michigan) and Yves Goddéris (Géosciences Environnement Toulouse). Editor Danny M. Rye (Yale University) handled the peer-review of the manuscript. The idea for this work was originally conceived collectively among the coauthors as part of class, Evolution of Earth Systems, at Stanford Unviersity. Jeremy K. Caves Rugenstein, Aviv Bachan, and myself contributed equally to the final completion of this manuscript. I co-wrote the manuscript, co-developed the quantitative analysis, helped carry out the thermodynamic calculations, and designed and produced all figures. Jeremy K. Caves Rugenstein co-wrote the manuscript, co-developed the quantitative analysis and helped 
design figures. Aviv Bachan co-developed the quantitative analysis, helped design figures and edited the manuscript. Andres Baresch compiled the paired catchment datasets and edited the manuscript. Kimberly V. Lau helped develop the quantitative analysis, helped design figures and edited the manuscript. Dana L. Thomas carried out the thermodynamic calculations, helped design figures, and edited the manuscript. Jung-Eun Lee provided climate model output and edited the manuscript. C. Kevin Boyce helped develop the modeling framework, helped design figures and co-wrote the manuscript. C. Page Chamberlain compiled the original version of the manuscript, helped design figures and helped design the quantitative analysis.

I presented this chapter at the 2017 American Geophysical Union Fall Meeting. It was also presented by co-author Jeremy K. Caves Rugenstein at Goldschmidt 2017 in Paris, France, and by co-author C. Page Chamberlain at the University of Washington Earth and Space Sciences Seminar in 2018 and the 2017 Senckenberg Geobiodiversity meeting in Frankfurt, Germany.

\section{First-Author Conference Contributions}

DE Ibarra, S Moon, M Winnick, A Wymore, JK Caves, CP Chamberlain, WH McDowell, K Maher, 2017, Partitioning Concentration-Discharge Patterns of Weathering Products from Monolithologic Catchments to Global Rivers. Invited Oral Presentation B54D-08, 2017 AGU Fall Meeting.

DE Ibarra, JK Caves Rugenstein, A Bachan, A Baresch, KV Lau, D Thomas, J-E Lee, CK Boyce, CP Chamberlain, 2017, The Evolution of Land Plants and the Silicate Weathering Feedback. Abstract PP41B-1300, 2017 AGU Fall Meeting. 
DE Ibarra, S Moon, JK Caves, CP Chamberlain, K Maher, 2017, Concentrationdischarge patterns of weathering products from global rivers. Abstract P-S02-21, $11^{\text {th }}$ Symposium of the Geochemistry of the Earth's Surface (GES-11).

DE Ibarra, JL Oster, MJ Winnick, JK Caves, AJ Ritch, CP Chamberlain, K Maher, 2016, Drivers of pluvial lake distributions in western North America. Invited Oral presentation PP51F-01, 2016 AGU Fall Meeting.

DE Ibarra, JL Oster, MJ Winnick, AJ Ritch, CP Chamberlain, K Maher, 2016, Climatological drivers of Plio-Pleistocene pluvial lake distributions in western North America. Invited Oral presentation 30-9, 2016 GSA Annual Meeting.

DE Ibarra, JL Oster, MJ Winnick, AJ Ritch, CP Chamberlain, K Maher, 2015, Climatological Conditions Driving Lake Levels During Past Cold and Warm Periods in Western North America. Abstract PP13B-2275, 2015 AGU Fall Meeting.

DE Ibarra, MM Jones, SA Graham, BB Sageman, CP Chamberlain, 2015, Investigating the Coniacian-Santonian in the Songliao Basin and possible links to Oceanic Anoxic Event 3. Oral presentation 53-13, 2015 GSA Annual Meeting.

DE Ibarra, JK Caves, S Moon, CP Chamberlain, K Maher, 2015, Constraining silicate weathering efficiency using concentration-discharge relationships of basaltic and granitic catchments. Critical Zone Observatory (CZO) Concentration-Discharge Workshop.

DE Ibarra, JK Caves, DL Thomas, CP Chamberlain, K Maher, 2014, Quantifying the Chemical Weathering Efficiency of Basaltic Catchments, Abstract EP23B-3602, 2014 AGU Fall Meeting. 
DE Ibarra and CP Chamberlain, 2014, Modeling terminal lake temperature and runoff using ostracod paleoclimate records. Oral presentation 80-3, 2014 GSA Annual Meeting.

\section{Co-authored Peer-Review Manuscript Contributions}

The following are the published peer-reviewed papers I contributed to during my time in the Earth System Science PhD program. This encompasses published work undertaken between September 2013 and June 2018.

AE Egger, DE Ibarra, R Weldon, RM Landgridge, B Marion, J Hall, In Press, The influence of pluvial lake cycles on earthquake recurrence in the northwestern Basin and Range, USA. In Starratt, S.W., Rosen M.R., (Editors), From Saline to Freshwater: The Diversity of Western Lakes in Space and Time, Geological Society of America Special Paper Series.

NW Hermann, JL Oster, DE Ibarra, 2018, Spatial Patterns and Driving Mechanisms of Mid-Holocene Moisture in Western North America, Journal of Quaternary Science, 33 (4), 421-434.

MM Jones, DE Ibarra, Y Gao, BB Sageman, D Selby, CP Chamberlain, SA Graham, 2018, Evaluating Late Cretaceous OAEs and the influence of marine incursions on organic carbon burial in an expansive East Asian paleo-lake, Earth and Planetary Science Letters, 484, 41-52.

AS Wymore, RL Brereton, DE Ibarra, K Maher, WH McDowell, 2017, Critical zone structure controls concentration-discharge relationships and solute generation in 
forested tropical montane watersheds, Water Resources Research, 53 (7), 62796295.

JK Caves, BU Bayshashov, A Zhamangara, AJ Ritch, DE Ibarra, DJ Sjostrom, HT Mix, MJ Winnick, CP Chamberlain, 2017, Late Miocene uplift of the Tian Shan and Altai and reorganization of Central Asia climate, GSA Today, 17 (2).

Y Tong, DE Ibarra, JK Caves, T Mukerji, SA Graham, 2017, Constraining basin thermal history and petroleum generation using paleoclimate data in the Piceance Basin, Colorado, Basin Research, 29 (4), 542-553.

JK Caves, DY Moragne, DE Ibarra, BU Bayshashov, Y Gao, MM Jones, A Zhamangara, AV Arzhannikova, SG Arzhannikov, CP Chamberlain, 2016, The Neogene degreening of Central Asia, Geology, 44 (11), 889-890.

HT Mix, DE Ibarra, SA Graham, A Mulch, CP Chamberlain, 2016, A Hot and High Eocene Sierra Nevada, Geological Society of America Bulletin, 128 (3-4), 531542.

Y Gao, DE Ibarra, JK Caves, CS Wang, CP Chamberlain, SA Graham, HC Wu, 2016, Mid-latitude terrestrial climate of East Asia linked to global climate in the Late Cretaceous: REPLY, Geology, 44 (2), e379.

JL Oster, DE Ibarra, MJ Winnick, K Maher, 2015, Steering of the westerly storm track over western North America at the Last Glacial Maximum, Nature Geoscience, 8 (3), 201-205.

F von Blanckenburg, J Bouchez, DE Ibarra, K Maher, 2015, Stable runoff and weathering fluxes into the oceans over Quaternary climate cycles, Nature Geoscience, 8 (7), $538-542$. 
Y Gao, DE Ibarra, CS Wang, JK Caves, CP Chamberlain, SA Graham, HC Wu, 2015, Mid-latitude terrestrial climate of East Asia linked to global climate in the Late Cretaceous, Geology, 43 (4), 287-290.

Y Gao, CS Wang, ZF Liu, XJ Du, DE Ibarra, 2015, Diagenetic and paleoenvironmental controls on Late Cretaceous clay minerals in the Songliao Basin, northeast China, Clays and Clay Minerals, 63 (6), 469-484.

\section{Introductory References}

Antevs, E.V., 1925. On the Pleistocene history of the Great Basin. In Jones, J.C., Antevs E.V., Huntington, E. (Editors), Quaternary Climates, Carnegie Institution Monograph Series 352, 51-114.

Antevs, E., 1955. Geologic-Climatic Dating in the West. American Antiquity 20, $317-$ 335.

Arnold, J.R., Libby, W.F., 1951. Radiocarbon Dates. Science 113, 111-120.

Bachan, A., Lau, K.V., Saltzman, M.R., Thomas, E., Kump, L.R., Payne, J.L., 2017. American journal of science: A model for the decrease in amplitude of carbon isotope excursions across the phanerozoic. American Journal of Science 317, $641-676$.

Benson, L.V., Paillet, F.L., 1989. The use of total lake-surface area as an indicator of climatic change: Examples from the Lahontan basin. Quaternary Research 32, $262-275$.

Berger, A., 1988. Milankovitch Theory and climate. Reviews of Geophysics 26, 624657. 
Berner, R.A., Caldeira, K., 1997. The need for mass balance and feedback in the geochemical carbon cycle. Geology 955.

Bigeleisen, J., Mayer, M.G., 1947. Calculation of equilibrium constants for isotopic exchange reactions. The Journal of Chemical Physics 15, 261.

Boyce, C.K., Lee, J.-E., 2017. Plant Evolution and Climate Over Geological Timescales. Annual Review of Earth and Planetary Sciences 45, 61-87.

Broecker, W.S., Kaufman, A., 1965. Radiocarbon Chronology of Lake Lahontan and Lake Bonneville II, Great Basin. Geological Society of America Bulletin 76, 537566.

Broecker, W.S., Orr, P.C., 1958. Radiocarbon chronology of Lake Lahontan and Lake Bonneville. Geological Society of America Bulletin 69, 1009-1032.

Burls, N.J., Fedorov, A.V., 2017. Wetter subtropics in a warmer world: Contrasting past and future hydrological cycles. PNAS 114, 12888-12893.

Carroll, A.R., Bohacs, K.M., 1999. Stratigraphic classification of ancient lakes: Balancing tectonic and climatic controls. Geology 27, 99-102.

Caves, J.K., Bayshashov, B.U., Zhamangara, A., Ritch, A.J., Ibarra, D.E., Sjostrom, D.J., Mix, H.T., Winnick, M.J., Chamberlain, C.P., 2017. Late Miocene Uplift of the Tian Shan and Altai and Reorganization of Central Asia Climate. GSAT 27, 1-7.

Caves, J.K., Jost, A.B., Lau, K.V., Maher, K., 2016. Cenozoic carbon cycle imbalances and a variable weathering feedback. Earth and Planetary Science Letters 450, $152-163$.

Caves, J.K., Winnick, M.J., Graham, S.A., Sjostrom, D.J., Mulch, A., Chamberlain, C.P., 2015. Role of the westerlies in Central Asia climate over the Cenozoic. Earth and 
Planetary Science Letters 428, 33-43.

Chamberlain, C.P., Poage, M.A., Craw, D., Reynolds, R.C., 1999. Topographic development of the Southern Alps recorded by the isotopic composition of authigenic clay minerals, South Island, New Zealand. Chemical Geology 155, 279-294.

Chamberlain, C.P., Winnick, M.J., Mix, H.T., Chamberlain, S.D., Maher, K., 2014. The impact of neogene grassland expansion and aridification on the isotopic composition of continental precipitation. Global Biogeochemical Cycles 28, 992 1004.

Craig, H., 1953. The geochemistry of the stable carbon isotopes. Geochimica et Cosmochimica Acta 3, 53-92.

Craig, H., Gordon, L.I., 1965. Deuterium and oxygen 18 variations in the ocean and the marine atmosphere. In Tongiori, E. (Editor), Stable Isotopes in Oceanographic Studies and Paleotemperatures, Pisa Consiglio Nazionale delle Riche, Laboratorio de Geologia Nucleare, 1-122.

Dai, A., 2011. Drought under global warming: A review. Wiley Interdisciplinary Reviews: Climate Change 2, 45-65.

Dansgaard, W., 1964. Stable isotopes in precipitation. Tellus 16, 436-468.

Dansgaard, W., 1954. The O18-abundance in fresh water. Geochimica et Cosmochimica Acta 6, 241-260.

Druhan, J.L., Maher, K., 2014. A Model Linking Stable Isotope Fractionation to Water Flux and Transit Times in Heterogeneous Porous Media. Procedia Earth and Planetary Science 10, 179-188. 
Epstein, S., Mayeda, T., 1953. Variation of $\mathrm{O}^{18}$ content of waters from natural sources. Geochimica et Cosmochimica Acta 4, 213-224.

Friedrich, O., Norris, R.D., Erbacher, J., 2012. Evolution of middle to Late Cretaceous oceans-A 55 m.y. record of Earth's temperature and carbon cycle. Geology 40, $107-110$.

Gilbert, G.K., 1875. Report on the geology of portions of Nevada, Utah, California and Arizona. United States Geographic and Geological Explorations and Surveys West of the One Hundredth Meridian (Wheeler Survey) 3, 17-187.

Gilbert, G.K., 1885. The topographic features of lake shores. United States Geological Survey $5^{\text {th }}$ Annual Report, 69-123.

Gilbert, G.K., 1890. Lake Bonneville. United States Geological Survey Monograph 1, 438.

Greve, P., Orlowsky, B., Mueller, B., Sheffield, J., Reichstein, M., Seneviratne, S.I., 2014. Global assessment of trends in wetting and drying over land. Nature Geoscience 7, 716-721.

Hayes, J.M., Waldbauer, J.R., 2006. The carbon cycle and associated redox processes through time. Philosophical Transactions of the Royal Society of London B: Biological Sciences 361, 931-950.

Hays, J.D., Imbrie, J., Shackleton, N.J., 1976. Variations in the Earth's Orbit: Pacemaker of the Ice Ages. Science 194, 1121-1132.

Hoekstra, A.Y., Mekonnen, M.M., 2012. The water footprint of humanity. Proceedings of the National Academy of Sciences, U.S.A. 109, 3232-3237.

Holland, H.D., 2002. Volcanic gases, black smokers, and the great oxidation event. 
Geochimica et Cosmochimica Acta 66, 3811-3826.

Hubbs, C.L., Miller, R.R., 1948. The zoological evidence: Correlation between fish distribution and hydrographic history in the desert basins of western United States. In, The Great Basin with emphasis on glacial and postglacial times, Bulletin of the University of Utah, 38 (20), 17-166.

Hudson, A.M., Quade, J., 2013. Long-term east-west asymmetry in monsoon rainfall on the Tibetan Plateau. Geology 41, 351-354.

Hunt, C.B., 1980. G.K. Gilbert's Lake Bonneville studies. Geological Society of America Special Paper 183, 45-59.

Huntington, T.G., 2006. Evidence for intensification of the global water cycle: Review and synthesis. Journal of Hydrology 319, 83-95.

Huntington, T.G., Weiskel, P.K., Wolock, D.M., McCabe, G.J., 2018. A new indicator framework for quantifying the intensity of the terrestrial water cycle. Journal of Hydrology 559, 361-372.

Ibarra, D.E., Chamberlain, C.P., 2015. Quantifying closed-basin lake temperature and hydrology by inversion of oxygen isotope and trace element paleoclimate records. American Journal of Science 315, 781-808.

Ibarra, D.E., Egger, A.E., Weaver, K.L., Harris, C.R., Maher, K., 2014. Rise and fall of late Pleistocene pluvial lakes in response to reduced evaporation and precipitation: Evidence from Lake Surprise, California. Bulletin of the Geological Society of America 126, 1387-1415.

Ibarra, D.E., Caves, J.K., Moon, S., Thomas, D.L., Hartmann, J., Chamberlain, C.P., Maher, K., 2016. Differential weathering of basaltic and granitic catchments from 
concentration-discharge relationships. Geochimica et Cosmochimica Acta 190, 265-293.

Ibarra, D.E., Moon, S., Caves, J.K., Chamberlain, C.P., Maher, K., 2017. Concentrationdischarge patterns of weathering products from global rivers. Acta Geochimica 36 (3), 405-409.

Ibarra, D.E., Oster, J.L., Winnick, M.J., Caves Rugenstein, J.K., Byrne, M.P., Chamberlain, C.P., 2018. Warm and cold wet states in the western United States during the Pliocene-Pleistocene. Geology 46, 355-358.

Ibarra, D.E., Caves Rugenstein, J.K., Bachan, A., Baresch, A., Lau, K.V., Thomas, D.L., Lee, J.E., Boyces, C.K., Chamberlain, C.P., Accepted, Modeling the consequences of land plant evolution on silicate weathering. American Journal of Science

Jones, M.M., Ibarra, D.E., Gao, Y., Sageman, B.B., Selby, D., Chamberlain, C.P., Graham, S.A., 2018. Evaluating Late Cretaceous OAEs and the influence of marine incursions on organic carbon burial in an expansive East Asian paleo-lake. Earth and Planetary Science Letters 484, 41-52.

Knoll, A.H., 2003. The geological consequences of evolution. Geobiology 1, 3-14.

Kump, L.R., Arthur, M.A., 1997. Global Chemical Erosion during the Cenozoic: Weatherability Balances the Budgets, in: Tectonic Uplift and Climate Change. Springer US, Boston, MA, pp. 399-426.

Kump, L.R., Brantley, S.L., Arthur, M.A., 2000. Chemical weathering, atmospheric $\mathrm{CO}_{2}$, and climate. Annual Review of Earth and Planetary Sciences 28, 611-667.

Lee, C.-T.A., Caves, J., Jiang, H., Cao, W., Lenardic, A., McKenzie, N.R., Shorttle, O., 
Yin, Q.-Z., Dyer, B., 2018. Deep mantle roots and continental emergence: implications for whole-Earth elemental cycling, long-term climate, and the Cambrian explosion. International Geology Review 60, 431-448.

Lenton, T.M., Boyle, R.A., Poulton, S.W., Shields-Zhou, G.A., Butterfield, N.J., 2014. Co-evolution of eukaryotes and ocean oxygenation in the Neoproterozoic era. Nature Geoscience 7, 257.

Libby, W.F., 1954. Chicago Radiocarbon Dates V. Science 120, 733-742.

Libby, W.F., 1952. Chicago Radiocarbon Dates, III. Science 116, 674-681.

Lisiecki, L.E., Raymo, M.E., 2005. A Pliocene-Pleistocene stack of 57 globally distributed benthic $\delta 180$ records. Paleoceanography $20, \mathrm{n} / \mathrm{a}-\mathrm{n} / \mathrm{a}$.

Maher, K., 2011. The role of fluid residence time and topographic scales in determining chemical fluxes from landscapes. Earth and Planetary Science Letters 312, 48-58.

Maher, K., 2010. The dependence of chemical weathering rates on fluid residence time. Earth and Planetary Science Letters 294, 101-110.

Maher, K., Chamberlain, C.P., 2014. Hydrologic regulation of chemical weathering and the geologic. Science 343, 1502-1504.

Maher, K., Druhan, J., 2014. Relationships between the Transit Time of Water and the Fluxes of Weathered Elements through the Critical Zone. Procedia Earth and Planetary Science 10, 16-22.

Maher, K., Ibarra, D.E., Oster, J.L., Miller, D.M., Redwine, J.L., Reheis, M.C., Harden, J.W., 2014. Uranium isotopes in soils as a proxy for past infiltration and precipitation across the western United States. American Journal of Science 314, $821-857$. 
Maher, K., Steefel, C.I., White, A.F., Stonestrom, D.A., 2009. The role of reaction affinity and secondary minerals in regulating chemical weathering rates at the Santa Cruz Soil Chronosequence, California. Geochimica et Cosmochimica Acta 73, 2804-2831.

Mifflin, M.D., Wheat, M.M., 1979. Pluvial lakes and estimated pluvial climates of Nevada. Nevada Bureau of Mines and Geology Bulletin 95, 57.

Milankovitch, M., 1920, Théorie mathématique des phénomènes thermiques produits par la radiation solaire. Paris, Gautheir-Vallars et Cie, 340.

Mulch, A., Graham, S.A., Chamberlain, C.P., 2006. Hydrogen Isotopes in Eocene River Gravels and Paleoelevation of the Sierra Nevada. Science 313, 87-89.

Munroe, J.S., Laabs, B.J.C., 2013. Temporal correspondence between pluvial lake highstands in the southwestern US and Heinrich Event 1. Journal of Quaternary Science 28, 49-58.

Orme, A.R., 2008. Pleistocene pluvial lakes of the American West: a short history of research. Geological Society, London, Special Publications 301, 51-78.

Oster, J.L., Ibarra, D.E., Winnick, M.J., Maher, K., 2015. Steering of westerly storms over western North America at the Last Glacial Maximum. Nature Geoscience 8, 201-205.

Payne, J., Kump, L., 2007. Evidence for recurrent Early Triassic massive volcanism from quantitative interpretation of carbon isotope fluctuations. Earth and Planetary Science Letters 256, 264-277.

Payne, J.L., Lehrmann, D.J., Wei, J., Orchard, M.J., Schrag, D.P., Knoll, A.H., 2004. Large perturbations of the carbon cycle during recovery from the end-permian 
extinction. Science 305, 506-509.

Pound, M.J., Tindall, J., Pickering, S.J., Haywood, A.M., Dowsett, H.J., Salzmann, U., 2014. Late Pliocene lakes and soils: a global data set for the analysis of climate feedbacks in a warmer world. Climate of the Past 10, 167-180.

Reheis, M., 1999. Highest pluvial-lake shorelines and Pleistocene climate of the western Great Basin. Quaternary Research 52, 196-205.

Reheis, M.C., Adams, K.D., Oviatt, C.G., Bacon, S.N., 2014. Pluvial lakes in the Great Basin of the western United States-a view from the outcrop. Quaternary Science Reviews 97, 33-57.

Russell, I.C., 1884. A geological Reconnaissance in Southern Oregon. Annual Report of the Director of the United States Geological Survey, 4, 431-464.

Russell, I.C., 1885. Geological history of Lake Lahontan: a Quaternary lake of northwestern Nevada. United States Geological Survey Monograph, 11 (1885), 288.

Russell, I.C., 1889, Quaternary history of Mono Valley, California. United States Geological Survey $8^{\text {th }}$ Annual Report, 261-394.

Saltzman, M.R., Thomas, E., 2012. Carbon Isotope Stratigraphy, in: The Geologic Time Scale. Elsevier, pp. 207-232.

Scheff, J., Frierson, D.M.W., 2014. Scaling potential evapotranspiration with greenhouse warming. http://dx.doi.org/10.1175/JCLI-D-14-00153.1 27, 1539-1558.

Seager, R., Ting, M., Held, I., Kushnir, Y., Lu, J., Vecchi, G., Huang, H.-P., Harnik, N., Leetmaa, A., Lau, N.-C., Li, C., Velez, J., Naik, N., 2007. Model projections of an imminent transition to a more arid climate in southwestern North America. 
Science 316, 1181-1184.

Shackleton, N.J., Opdyke, N.D., 1977. Oxygen isotope and palaeomagnetic evidence for early Northern Hemisphere glaciation. Nature 270, 216.

Sherwood, S., Fu, Q., 2014. Climate change. A drier future? Science 343, 737-739.

Sleep, N.H., Bird, D.K., 2008. Evolutionary ecology during the rise of dioxygen in the Earth's atmosphere. Philosophical Transactions of the Royal Society of London B: Biological Sciences 363, 2651-2664.

Sleep, N.H., Zahnle, K., 2001. Carbon dioxide cycling and implications for climate on ancient Earth. Journal of Geophysical Research: Solid Earth (1978-2012) 106, $1373-1399$.

Urey, H.C., 1952. On the Early Chemical History of the Earth and the Origin of Life. PNAS 38, 351-363.

Urey, H.C., 1948. Oxygen isotopes in nature and in the laboratory. Science 108, 489496.

Urey, H.C., 1947. The thermodynamic properties of isotopic substances. Journal of the Chemical Society $562-581$.

Urey, H.C., Lowenstam, H.A., Epstein, S., McKinney, C.R., 1951. Measurements of paleotemperatures of the Upper Cretaceous of England, Denmakr and the southeastern United States. Geological Society of America Bulletin 62, 399-416.

Veizer, J., Ala, D., Azmy, K., Bruckschen, P., Burhn, F., Carden, G.A.F., Diener, A., Ebneth, S., Goddéris, Y., Jasper, T., Korte, C., Pawellek, F., Podlaha, O.G., Strauss, H., $1999 .{ }^{87} \mathrm{Sr} /{ }^{86} \mathrm{Sr}, \delta^{13} \mathrm{C}$ and $\delta^{18} \mathrm{O}$ evolution of Phanerozoic seawater. Chemical Geology 161, 59-88. 
Volk, T., 1987. Feedbacks between weathering and atmospheric $\mathrm{CO}_{2}$ over the last 100 million years. America Journal of Science 287, 763-779.

von Blanckenburg, F., Bouchez, J., Ibarra, D.E., Maher, K., 2015. Stable runoff and weathering fluxes into the oceans over Quaternary climate cycles. Nature Geoscience 8, 538-542.

Walker, J.C.G., Hays, P.B., Kasting, J.F., 1981. A negative feedback mechanism for the long-term stabilization of Earth's surface temperature. Journal of Geophysical Research 86, 9776-9782.

Winnick, M.J., Maher, K., 2018. Relationships between $\mathrm{CO}_{2}$, thermodynamic limits on silicate weathering, and the strength of the silicate weathering feedback. Earth and Planetary Science Letters 485, 111-120.

Winnick, M.J., Welker, J.M., Chamberlain, C.P., 2013. Stable isotopic evidence of El Niño-like atmospheric circulation in the Pliocene western United States. Climate of the Past 9, 903-912.

Wymore, A.S., Brereton, R.L., Ibarra, D.E., Maher, K., McDowell, W.H., 2017. Critical zone structure controls concentration-discharge relationships and solute generation in forested tropical montane watersheds. Water Resources Research $53,6279-6295$.

Zachos, J., Pagani, M., Sloan, L., Thomas, E., Billups, K., 2001. Trends, Rhythms, and Aberrations in Global Climate 65 Ma to Present. Science 292, 686-693.

Zachos, J.C., Dickens, G.R., Zeebe, R.E., 2008. An early Cenozoic perspective on greenhouse warming and carbon-cycle dynamics. Nature 451, 279. 


\title{
CHAPTER 1
}

Quantifying closed-basin lake temperature and hydrology by inversion of oxygen isotope and trace element paleoclimate records

\author{
Daniel E. Ibarra and C. Page Chamberlain
}

Department of Earth System Science, Stanford University, Stanford, CA 94305, USA

\footnotetext{
Reproduced with permission from Ibarra, D.E., and Chamberlain, C.P., American Journal of Science. Copyright 2015, HighWire Press.
}

Licensed under the Creative Commons Attribution-NonCommercial 3.0 http://creativecommons.org/licenses/by-nc/3.0 


\section{Abstract}

Lake systems are important paleoclimate archives that preserve ecosystem and hydrologic responses to critical periods in Earth history, such as carbon cycle perturbations and glacial-interglacial cycles. Geochemical measurements of biogenic carbonate (for example, $\delta^{18} \mathrm{O}, \delta^{13} \mathrm{C},{ }^{87} \mathrm{Sr} /{ }^{86} \mathrm{Sr},[\mathrm{Li}]$, [U], [Sr], and [Mg]) are indicators of hydrologic variability in lake systems throughout the geologic record. In this study, we present a new closed-basin lake modeling approach, HyBIM (the Hydrologic Balance Inverse Model) that employs a system of total differential equations and uses the measured $\delta^{18} \mathrm{O}, \mathrm{Sr} / \mathrm{Ca}$, and $\mathrm{Mg} / \mathrm{Ca}$ of biogenic carbonate to determine changes in temperature, runoff, and lake evaporation. Using equally-spaced time steps, these equations are simultaneously solved to constrain the hydrologic parameters of the lake as recorded in biogenic carbonate. We use a Monte Carlo approach to account for uncertainty in the input parameters, such as $\delta^{18} \mathrm{O}$ temperature relationships, partition coefficient uncertainty, and watershed solute chemistry.

For illustrative purposes, we apply the model to two ostracod valve datasets covering different timescales: (1) the Cretaceous Songliao Basin, northeast China, and (2) Holocene Lake Miragoane, Haiti. Modern water measurements of water isotopes and cation concentrations from each location are required as model inputs. We compare our modeling results with author interpretations and geologic observations. The modeling approach presented in this study can be applied to other closed-basin lake records, can be modified for other calcifying species (for example, gastropods or mollusks) or with calibration to inorganic lacustrine carbonate. In addition, this approach holds promise for extension with additional proxy measurements (that is, $\delta \mathrm{D}, \mathrm{U} / \mathrm{Ca}$ or $\mathrm{Li} / \mathrm{Ca}$ ) and changing 
source area on tectonic timescales using proxies that reflect changing source lithology

(that is, $\mathrm{Sr}$ and $\mathrm{Pb}$ isotopes). Future incorporation of age model uncertainty in the Monte Carlo approach will also provide utility by quantifying temporal uncertainty on the hydrologic response recorded by lake sediments.

Keywords: lakes, paleohydrology, inverse model, trace elements, oxygen isotopes 


\subsection{Introduction}

Lake systems provide valuable paleoclimate archives as natural integrators of terrestrial processes. Lake deposits from hydrologically closed basins or terminal lakes record important changes in climate, human activity, hydrology, ecology, and tectonics (Antevs, 1948; Eugster and Jones, 1979; Currey, 1990; Binford and others, 1997; Carroll and Bohacs, 1999; Reheis, 1999; Demko and others, 2005; Horton and Chamberlain, 2006; Davis and others, 2009; Reheis and others, 2014; Hillman and others, 2014; Smith and others, 2014). Additionally, lake sediments provide the most widely available and continuous records of terrestrial climate available to reconstruct past climate (for example, Oviatt and McCoy, 1992; Colman and others, 1995; Williams and others, 1997; Bohacs and others, 2003; Melles and others, 2012). Accurate estimates of past precipitation, runoff, and/or temperature are important for studying the evolution of landscapes and the diversification and migration of species, as well as to test climate model predictions of past climate (for example, Rozanski and others, 1997; Partridge and others, 1997; Steinman and others, 2012; Ibarra and others, 2014).

Studies of ancient lake systems have long sought to infer climate conditions leading to the existence and persistence of lakes in terrestrial settings. Inferring the climatic setting and the open versus closed hydrology of a lake system using facies identification has been extensively investigated (for example, Nilsson, 1931; Eugster and Kelts, 1983; Kelts, 1988; Talbot, 1990; Carroll and Bohacs, 1999). Within the Carroll and Bohacs (1999) framework, closed-basin lakes are of two types: balanced-fill and underfilled. Underfilled lake systems are identified by evaporative facies (Jones and others, 1977; Eugster and Jones, 1979; Horita, 1990) and are typical of many Quaternary 
playa-lake systems found in semi-arid regions of the mid-latitudes, such as the western United States (Mifflin and Wheat, 1979; Reheis and others, 2014). In contrast, balancedfilled lake systems are typical of freshwater to saline conditions with mixed carbonate and siliciclastic sediments (for example, Carrol, 1998; Kempf and others, 2009; Doebbert and others, 2014).

For closed-basin Quaternary lake systems, in which tectonic rearrangement is negligible, climatic conditions have been quantified using measures of lake surface area and tributary size (Snyder and Langbein, 1962; Mifflin and Wheat, 1979; Bowler, 1981; Benson and Paillet, 1989; Bengtsson and Malm, 1997; Reheis, 1999; Sack, 2009; Broecker, 2010; Munroe and Laabs, 2013; Hudson and Quade, 2013; Ibarra and others, 2014; Huth and others, 2015; Hudson and others, 2015). Additionally, recent work modeling stable isotopes in closed-basin balance-filled lakes takes advantage of longer (relative to overfilled/open lakes) residence times to infer climatic conditions by relating the $\delta^{18} \mathrm{O}$ or $\delta \mathrm{D}$ to the hydrologic balance (Horita, 1990; Hostetler and Benson, 1994; Benson and White, 1994; Gibson and others, 2002; Gibson and Edwards, 2002; Benson and Paillet, 2002; Russell and Johnson, 2006; Jones and others, 2007; Jones and Imbers, 2010; Doebbert and others, 2010; Steinman and others, 2010a, 2010b, 2012, 2013;

Steinman and Abbott, 2013; Jasechko and others, 2013; Stansell and others, 2013; Ibarra and others, 2014; Jasechko and others, 2014; Gibson and others, 2015). Fundamental to applying an isotopic modeling approach are assumptions concerning the watershed precipitation-runoff relationships (Jones and others, 2007; Ibarra and others, 2014), mixing or stratification of the lake (Imberger and Ivey, 1991), basin-scale and regional vapor recycling (Gat and Matsui, 1991; Gat and others, 1994; Burnett and others, 2003; 
Winnick and others, 2014), and groundwater influences (Krabbenhoft and others, 1990a, 1990b; Shapley and others, 2005; Guay and others, 2004; Steinman and others, 2013). While these models offer powerful methods to reconstruct the hydrology of lake systems they are limited by the numerous input parameters required that are difficult to constrain in ancient lake systems. Another approach, outlined here, is to use additional measurements, such as trace elements, that can be meaningfully related to climatic conditions and will reduce the assumptions necessary for accurate, quantitative climatic reconstructions. Using trace element and oxygen isotope measurements it is then possible to tightly constrain the system using far fewer input parameters.

In this paper, we develop a new modeling framework exploiting variations in $\delta^{18} \mathrm{O}$ and trace elements ( $\mathrm{Mg}$ and $\mathrm{Sr}$ ) measured in lacustrine carbonates and utilizing a series of total differential equations. We apply this model to previously published ostracod paleoclimate records for closed basins. Lacustrine ostracod records are used here for illustrative purposes because of their broad paleoclimate applications in historical (for example, Engstrom and Nelson, 1991; Holmes and others, 2007a; Zhang and others, 2009), Quaternary (for example, Edney and others, 1990; Hodell and others, 1991; Curtis and Hodell, 1993; Lamb and others, 1999; Cohen and others, 2000; Holmes and others, 2007b; Gouramanis and others, 2010), and deep-time (for example, Forester, 1991; Chamberlain and others, 2013) settings. Extensive work has also been carried out on the ecology, taphonomy, and taxonomy of ostracod species (for example, Horne and others, 2002; Frogley and others, 2002; Bennett and others, 2011; Blome and others, 2014), and modern ostracod datasets have been extensively studied and provide the necessary empirical calibrations of trace element distribution coefficients and vital effects (for 
example, Engstrom and Nelson, 1991; Xia and others, 1997a, 1997b; Wansard and others, 1998; De Deckker and others, 1999; Dettman and others, 2002; Holmes and Chivas, 2002; Dwyer and others, 2002; Ito and Forester, 2009; Gouramanis and others, 2010; Marco-Barba and others, 2012; Börner and others, 2013) necessary to constrain our model. The modeling framework presented in this paper applies, given the existence of relevant and accurate calibrations, to any biogenic carbonate records from a closed-basin lake setting.

\subsection{Model Development}

We present the Hydrologic Balance Inversion Model (HyBIM), an inverse model using a system of total differential equations that are inverted to solve for the extensive variables in lake chemistry. The structure of the model is similar to models that quantify changes in the global carbon cycle and/or other biogeochemical cycles as recorded in marine sediments (for example, Goddéris and François, 1996; Derry and France-Lanord, 1996; François and Goddéris, 1998; Li and others, 2009; Li and Elderfield, 2013). We solve for the relative changes in temperature and lake volume, and thus rely only on the first derivative of the input dataset and not the absolute value of the isotopic and trace element measurements. Because of this formulation order of magnitude fluctuations in lake volume cannot be modeled by this approach. Fundamentally, this model quantifies the observations made by previous studies that qualitatively employed end-member mixing (from a fresh source to an evaporative lake) in closed-basin lacustrine deposits based on the covariance of $\mathrm{Sr} / \mathrm{Ca}, \mathrm{Mg} / \mathrm{Ca}, \delta^{18} \mathrm{O}$ and $\delta^{13} \mathrm{C}$ (for example, Müller and others, 1972; Eugster and Kelts, 1983; Talbot, 1990; Li and Ku, 1997; Garnett and others, 2004; 
Davis and others, 2009; Horton and Oze, 2012; McGee and others, 2012; Chamberlain and others, 2013; Horton and others, 2015). We do not incorporate variations in $\delta 13 \mathrm{C}$ in this initial iteration of HyBIM; however, evaporative processes and lake residence times should also control the systematics of the $\delta 13 \mathrm{C}$ of carbonates from terminal lake systems (see discussion in Horton and others, 2015).

First, we establish the modeling framework using a system of total differential equations. Second, we describe the Monte Carlo routine used to account for parameter and input data uncertainty (for example, Fantle, 2010; Royer and others, 2014). Third, we discuss the input dataset (the time series of measurements) and necessary input parameters. Finally, we describe the quantification of the partial derivatives necessary to constrain the model and necessary input parameters. This model is available as an example R code for modification at:

http://earth.geology.yale.edu/ ajs/SupplementaryData/2015/Ibarra/. For illustrative purposes, we apply HyBIM to two ostracod valve datasets covering different timescales: (1) the Cretaceous Songliao Basin, northeast China, and (2) Holocene Lake Miragoane, Haiti. All model parameters are summarized in table 1 and a schematic of the model structure is presented in figure A1.

\section{Model Framework}

Here, we present a modeling framework that produces a time series of temperature changes, effects of evaporation, and relative volume estimates for runoff for carbonate-bearing (here ostracods) paleolake records. Chivas and others (1986) previously suggested a quantitative framework by which a unique solution for 
paleotemperature and paleosalinity could be calculated using paired $\mathrm{Mg} / \mathrm{Ca}$ and $\delta^{18} \mathrm{O}$ measurements. Following this observation, we write three total differential equations for lake water that describe the effects of temperature, evaporation, and runoff/precipitation on the oxygen isotopic and trace element concentration of ostracods in a hydrologically closed lake. The three total differential equations (for lake water $\delta^{18} \mathrm{O},[\mathrm{Mg}]$, and [Sr]) are:

$$
\begin{aligned}
& d\left(\delta^{18} O\right)=\left(\frac{\partial\left(\delta^{18} O\right)}{\partial T}\right) d T+\left(\frac{\partial\left(\delta^{18} O\right)}{\partial F_{\text {evap }}}\right) d F_{\text {evap }}+\left(\frac{\partial\left(\delta^{18} O\right)}{\partial F_{\text {input }}}\right) d F_{\text {input }} \\
& d[S r]=\left(\frac{\partial[S r]}{\partial T}\right) d T+\left(\frac{\partial[S r]}{\partial F_{\text {evap }}}\right) d F_{\text {evap }}+\left(\frac{\partial[S r]}{\partial F_{\text {input }}}\right) d F_{\text {input }} \\
& d[M g]=\left(\frac{\partial[M g]}{\partial T}\right) d T+\left(\frac{\partial[M g]}{\partial F_{\text {evap }}}\right) d F_{\text {evap }}+\left(\frac{\partial[M g]}{\partial F_{\text {input }}}\right) d F_{\text {input }}
\end{aligned}
$$

where $\delta^{18} \mathrm{O}$ is the oxygen isotopic composition of the lake water determined from biogenic carbonate measurements corrected for species-specific vital effects, $[\mathrm{Mg}]$ and [Sr] are the lake water concentrations of $\mathrm{Mg}^{2+}$ and $\mathrm{Sr}^{2+}$ determined from the $\mathrm{Sr} / \mathrm{Ca}$ and $\mathrm{Mg} / \mathrm{Ca}$ ratios measured in the biogenic carbonate, $\mathrm{T}$ is mean annual surface air temperature $(\mathrm{K})$ for the lake basin, $\mathrm{F}_{\text {evap }}$ is the fraction of the lake evaporation, and $\mathrm{F}_{\text {input }}$ is the fractional lake volume increase due to changes in runoff and precipitation (see table 1).

We treat equations $1-3$ as a system of total differential equations that can be solved for each time step of the first derivative of the $[\mathrm{Mg}],[\mathrm{Sr}]$, and $\delta^{18} \mathrm{O}$ time series [that is, $\mathrm{x}=\mathrm{A}-1 \mathrm{~b}$, where matrix $\mathrm{A}$ is composed of the partial derivatives, the $\mathrm{b}$ vector is the first derivative of the input dataset (left side of eqs 1 to 3 ) and $\mathrm{x}$ is the solution vector of $\left(\mathrm{dT}, \mathrm{dF}_{\text {evap }}\right.$, and $\left.\left.\mathrm{dF}_{\text {input }}\right)\right]$. We do so by determining the partial derivatives for a specific 
lake system, calibrated using modern watershed/lake chemistry data and knowledge of the specific ostracod species. Interpolation to an evenly spaced time series is required, which we accomplish using an Epanechnikov kernel smoother applied to the input data. We assume that within each time step, lake evaporation and/or lake volume change does not change more than 20 percent, and we approximate all derivatives according to this assumption (that is at $10 \%)$. The model output is a time series of the solution vector ( $\mathrm{dT}$, $\mathrm{dF}_{\text {evap }}$, and $\left.\mathrm{dF}_{\text {input }}\right) . \mathrm{dF}_{\text {evap }}$ and $\mathrm{dF}_{\text {input }}$ are combined to give the fractional net volume increase for each time-step (see fig. A1). We use a Monte Carlo approach to account for uncertainty in the input parameters and in the input dataset, which we derive from kernel smoothing.

\section{Monte Carlo Routine for Uncertainty Quantification}

Given the assumptions that underlie the input parameters and data set for this model it is critical to quantitatively assess the errors associated with the calculated runoff input, temperature changes, and evaporative effects. Thus, we use a Monte Carlo routine to account for two types of uncertainty. The first is uncertainty in the input dataset. Since most paleoclimate records display uneven variance and non-uniform sampling density, it is necessary to account for this by producing datasets for each iteration based on the statistics (time series of the mean and residuals) derived from kernel smoothing of the dataset (see below). To do so, for each Monte Carlo iteration we implement a bootstrapping method whereby we account for input dataset uncertainty by re-sampling residuals. The second type of uncertainty accounted for by our model is the uncertainty in the input parameters. The input parameters are best determined by modern watershed and 
lake chemistry (when available) and knowledge of the species precipitating the biogenic carbonate (described below). Within each Monte Carlo iteration, we derive a time series of partial derivatives based on the input parameters. Input parameter uncertainty distributions are assumed to be normal distributions, requiring that uncertainty is quantified by as many modern measurements of watershed chemistry as possible. The partial derivatives are substituted into the A matrix at each time step.

\section{Input Dataset Requirements and Interpolations}

There are two requirements for the input dataset that need to be met for this model. First, the modeled $\mathrm{Mg} / \mathrm{Ca}, \mathrm{Sr} / \mathrm{Ca}$, and $\delta^{18} \mathrm{O}$ time series must be of sufficient resolution to resolve climatic events of interest and the time step must be greater than the residence time of these elements in a lake. Thus, in order to use the dataset in the system of equations (left side of eqs $1-3$ ), the time series must be interpolated to even time steps, requiring a sufficiently resolved age model for the $\mathrm{Mg} / \mathrm{Ca}, \mathrm{Sr} / \mathrm{Ca}$, and $\delta^{18} \mathrm{O}$

measurements. Smoothing of each time series $\left(\mathrm{Mg} / \mathrm{Ca}, \mathrm{Sr} / \mathrm{Ca}\right.$, and $\left.\delta^{18} \mathrm{O}\right)$ is performed using an Epanechnikov kernel and interpolated to an even time step following a data driven least squares cross-validation to select the appropriate kernel bandwidth (Hayfield and Racine, 2008). The Epanechnikov kernel (Epanechnikov, 1969) is used because it has finite boundaries (instead of Gaussian kernel) and is smooth (compared to a triangle or uniform kernel) (see Fan, 1992; Danese and others, 2014). Kernel smoothing of the time series is implemented using the 'np' package in R (Hayfield and Racine, 2008). The additional advantage of using a kernel smoother is that uncertainty of the interpolated 
dataset can be quantified along the time series (mean and residuals) and input into the Monte Carlo routine.

While high-resolution interpolation of the smoothed dataset is desirable to resolve climatic events of interest, linear interpolation of the input dataset to an even time step ( $\Delta \mathrm{t}$ ) must be such that $\Delta \mathrm{t}>>\tau_{\text {res }}$, where $\tau_{\text {res }}$ is the residence time (inferred from lake geometry and average input or evaporative fluxes, for example Gibson and others, 2002; Jasechko and others, 2014). For lakes with no modern analogue (see Cretaceous Songliao Basin example), first-order estimates for $\tau_{\text {res }}$ can be approximated using scaling relationships between outcrop size and basin geometry (Hendriks and others, 2012), which in combination with facies identification can be used to determine estimates of the relationship between potential accommodation and basin average precipitation/evaporation (Carroll and Bohacs, 1999). Thus, due to the formulation and assumptions of the mixing and mass conservation relationships derived below, resolving hydrologic or climatic events over intervals equal to or shorter than $\tau_{\text {res }}$ is not possible within this modeling framework. This implies that, given the 'water equivalency rule' for a region of interest (Hendriks and others, 2012), paleoclimate records from small lake systems, which integrate smaller watersheds and have shorter residence times, provide the highest fidelity temporal records of hydrologic cycle changes. Furthermore, determination of the lake hypsometry and/or outcrop extent (for example, Reheis 1999; Sack, 2009; Steinman and others, 2013; Smith and others, 2014; Doebbert and others, 2014) ensures that the modeling assumptions outlined above are met.

The second requirement for the model is that all of the input data need to be placed in terms of lake composition. Although we use measured values of $\mathrm{Mg} / \mathrm{Ca}, \mathrm{Sr} / \mathrm{Ca}$, 
and $\delta^{18} \mathrm{O}$ of ostracods, these values need to be corrected so that they represent the values of these elements and isotopes in the lake water. To make this correction one must correct for "vital effects" and temperature. Correcting for vital effects is relatively straightforward as the measured vital effect is simply subtracted from the measured ostracod values. Vital effects associated with the calcification of biogenic carbonate are observed because shell carbonate is not precipitated in isotopic equilibrium with water (Holmes and Chives, 2002). Vital effects observed in ostracod $\delta^{18} \mathrm{O}$ are positive (0.3$2.5 \%$ ) and have been observed to be constant within individual genera (Xia and others, 1997a, 1997b; von Grafenstein and others, 1999; Chivas and others, 2002; Didie and Bauch, 2002). Since vital effects are not temperature-dependent, data from a variety of different modern species fall on slopes close to the inorganic calcite equilibrium slope $(-0.250 \% / \mathrm{K})$ of Kim and O'Neill (1997) (see compilation by Marco-Barab and others, 2012). Our model ideally should be used with a time series produced by a single ostracod species or genera. Although, if multiple species are measured (for example, Lister and others, 1991) this could be accounted for using vital effect offsets.

In contrast, correcting for temperature effects is less straightforward and could, if done incorrectly, lead to "circular reasoning" since we are attempting to constrain temperature changes in the model. We assume temperature could vary from 10 to $35^{\circ} \mathrm{C}$ (uniform distribution). For each Monte Carlo iteration we select a starting temperature and assume that $\delta^{18} \mathrm{O}$ of the lake water is in equilibrium with the measured $\delta^{18} \mathrm{O}$ of ostracods using the temperature-dependent fractionation relationship of Kim and O'Neill (1997) corrected for vital effects. We avoid "circular reasoning" since our system of linear equations calculates the relative changes in temperature, $\mathrm{dT}$ (in the $\mathrm{x}$ vector), using 
the first derivative of the $\delta^{18} \mathrm{O}$ of the lake water (in the $\mathrm{b}$ vector), not the absolute temperature.

Distribution coefficients $\left(\mathrm{K}_{\mathrm{D}}\right.$-values) relating trace element to calcium ratios are commonly determined for biogenic carbonates through modern and/or culturing studies. The distribution (or partition) coefficient is defined as:

$$
\mathrm{K}_{\mathrm{D}}[\mathrm{M}]=\frac{\mathrm{M} / \mathrm{Ca}_{\text {water }}}{\mathrm{M} / \mathrm{Ca}_{\text {shell }}}
$$

where $\mathrm{M}$ is the trace metal, such as $\mathrm{Sr}, \mathrm{Mg}$, or $\mathrm{U}$, and $\mathrm{M} / \mathrm{Ca}$ are molar ratios. $\mathrm{K}_{\mathrm{D}^{-}}$-values for $\mathrm{Mg}$ and $\mathrm{Sr}$ are both less than one, meaning that both trace metals are actively excluded during calcification. Additionally, Chivas and others (1986) demonstrated that $\mathrm{K}_{\mathrm{D}}$-values are similar among members of the same or closely related genera.

In many species, $\mathrm{K}_{\mathrm{D}}$ has been shown to be temperature-dependent. In most ostracod species, there is little or no temperature effect on $\mathrm{Sr} / \mathrm{Ca}$ (Chivas and others, 1986; Holmes and Chivas, 2002, Marco-Barab and others, 2012), but the $\mathrm{Mg} / \mathrm{Ca} \mathrm{K}_{\mathrm{D}}$ in ostracods is temperature-dependent (Engstrom and Nelson, 1991; DeDeckker and others, 1999; Holmes and Chivas, 2002). For the example datasets used in this paper, we use species-specific $\mathrm{K}_{\mathrm{D}}$-values (or from related genera when not available), and uncertainties are obtained from regression statistics of the original datasets (table 2). To place the input data $[\mathrm{Mg}]$ and $[\mathrm{Sr}]$ in terms of lake composition (b vector) we calculate the $\mathrm{Mg} / \mathrm{Ca} \mathrm{K}_{\mathrm{D}}$ (and $\mathrm{Sr} / \mathrm{Ca} \mathrm{K}_{\mathrm{D}}$ if necessary) using the temperature and lake water [Ca] selected for each Monte Carlo iteration. 


\section{Determining Partial Derivatives}

In the following sections each of the partial derivatives are derived or determined using either mass conservation (for example, $\frac{\partial[\mathrm{Mg}]}{\partial \mathrm{F}_{\text {evap }}}$ ) and mixing (for example, $\frac{\partial[\mathrm{Mg}]}{\partial \mathrm{F}_{\mathrm{vol}}}$ ), or empirical relationships from environmental and/or laboratory measurements (for example, $\left.\frac{\partial\left(\delta^{18} \mathrm{O}\right)}{\partial \mathrm{T}}\right)$

\section{Temperature Partial Derivatives}

To solve for the oxygen isotope partial derivative $\frac{\partial\left(\delta^{18} \mathrm{O}\right)}{\partial \mathrm{T}}$ requires knowing how $\delta^{18} \mathrm{O}$ of meteoric water (precipitation and runoff) varies as a function of temperature. We recognize that there are numerous factors affecting the $\delta^{18} \mathrm{O}$ of precipitation beyond that of temperature, which include seasonality, vapor recycling, moisture source et cetera. However, the commonly held assumption that underpins terrestrial paleoclimate studies is the well-known positive correlation between $\delta^{18} \mathrm{O}$ values of precipitation and temperature for temperate and high latitude areas (Dansgaard, 1964). For the mid-latitude site (Songliao Basin) we use the observed relationship between temperature and precipitation Rozanksi and others (1993) of $0.58 \%$ o/K, as has been used in numerous studies to calculate the temperature for paleoclimate archives in mid- to high-latitude sites, such as paleosols (for example, Koch and others, 2003), paleolakes (for example, Anderson and others, 2001), and ice cores (see Jouzel and others, 1997 and references therein). For the low latitude site (Lake Miragoane, Haiti) it is unlikely that the correlations of Rozanksi and others (1993) apply as these are for mid- to high-latitudes. Although it is not ideal to use the approach we outline in this paper to low latitudes 
because temperature is not as well correlated to the $\delta^{18} \mathrm{O}$ of precipitation, we use this site only as an example of how this approach can be used in lakes because this record offers the type of data that are necessary for these calculations. Recognizing these limitations we use a slope of $0.26 \% / \mathrm{K}$ for the tropical sites (see fig. A2). For both cases we incorporate the error associated with the empirical temperature versus $\delta^{18} \mathrm{O}$ correlation in the Monte Carlo.

In our model, thus, one of the assumptions inherent in our calculations is that temperature is the primary driver of $\delta^{18} \mathrm{O}$ value of water input to the lake. Note that since the slope between temperature and $\delta^{18} \mathrm{O}$ of precipitation can and does vary geographically, more accurate approaches can be tailored for individual sites by measurements of site-specific correlations between temperature and $\delta^{18} \mathrm{O}$ of precipitation. In addition, to the partial $\frac{\partial\left(\delta^{18} \mathrm{O}\right)}{\partial \mathrm{T}}$ discussed above it is necessary to place the ostracod values as the $\delta^{18} \mathrm{O}$ of lake water for these calculations (b vector of eqs 1 to 3 ). To do this we need to account for both vital effects and the temperature-dependent isotopic fractionation (see above).

In addition, there are minor temperature effects on the $\mathrm{Sr} / \mathrm{Ca}$ (typically none) and $\mathrm{Mg} / \mathrm{Ca}$ (see above discussion). Since the inputs (b vector of eqs 1 to 3 ) are placed in terms of lake composition, after accounting for the $\mathrm{Mg} / \mathrm{Ca}$ or $\mathrm{Sr} / \mathrm{Ca}$ of the lake water and selected temperature for the Monte Carlo iteration the temperature partial derivatives ( $\frac{\partial[\mathrm{Mg}]}{\partial \mathrm{T}}$ and $\frac{\partial[\mathrm{Sr}]}{\partial \mathrm{T}}$ ) are equal to zero. 


\section{Evaporation Partial Derivatives}

To account for the evaporative concentration of trace elements, we assume mass conservation of $\mathrm{Sr}$ and $\mathrm{Mg}$. Thus, this model is not applicable to brine or saline environments (see Jones and others, 1977; Eugster and Jones, 1979) nor is it applicable to systems that form large deposits of chemical sediments with high $\mathrm{Mg}$ and/or $\mathrm{Sr}$ concentrations. For biogenic carbonates, we apply the applicable distribution coefficient $\left(\mathrm{K}_{\mathrm{D}}\right)$ and take the first derivative. In doing so, we assume that the $\mathrm{Sr} / \mathrm{Ca}$ and $\mathrm{Mg} / \mathrm{Ca}$ measured in the biogenic carbonates are faithfully recording changes in the $\mathrm{Sr}$ and $\mathrm{Mg}$ concentrations of the lake water. Assuming mass conservation, the change in solute $\mathrm{M}$ concentration (from the initial concentration to an increased concentration at time 2) during fractional lake evaporation $\left(\mathrm{F}_{\mathrm{evap}}\right.$, fraction remaining, from 0 to 1 , where 1 is fully evaporated) is given by the equation (fig. 1):

$$
[\mathrm{M}]_{2}=\frac{[\mathrm{M}]_{\text {initial }}}{\left(1-\mathrm{F}_{\text {evap }}\right)}
$$

Solving for the partial derivative of equation 5 has the analytical solution:

$$
\frac{\partial[M]}{\partial F_{\text {evap }}}=\frac{[M]_{\text {initial }}}{\left(1-F_{\text {evap }}\right)^{2}}
$$

This relationship is non-linear; thus, to provide a linear slope for $\frac{\partial[\mathrm{M}]}{\partial \mathrm{F}_{\text {evap }}}$ we assume that for any given time step, the lake does not evaporate more than 20 percent by volume. By inspection of equation 6 , the average evaporation between 0 to 20 percent, given by Fevap $=0.1$, yields a slope of $\frac{[\mathrm{M}]_{\text {initial }}}{(0.9)^{2}}$. Therefore, the initial trace element concentration (that is, the $\mathrm{Mg}$ and $\mathrm{Sr}$ concentrations), which we assume to be approximated using the 
observed distribution of trace element measurements, is important for setting $[\mathrm{M}]_{\text {initial }}$ at each time step.

The evaporative enrichment of lake water $\delta^{18} \mathrm{O}$ with progressive evaporation was originally parameterized by Craig and Gordon (1965). The limitation of applying the Craig and Gordon (1965) evaporation model to lacustrine paleoclimate records, as outlined in detail by Gonfiantini (1986), is the large number of input parameters and the difficulty in constraining the isotopic composition of the evaporated water vapor (see discussion in Jones and Imbers, 2010). Recent work has attempted to simplify evaporative assumptions (Benson and White, 1994; Jones and others, 2007; Jones and Imbers, 2010; Placzek and others, 2011), but numerous input parameters are still required, making the generic application of these lake water evaporation models to paleoclimate records challenging.

Central to the difficulties encountered by previous researchers is the influence of humidity on the evolution of the isotopic composition of an evaporating water body (Gonfiantini, 1986). This is due to changes in the kinetic enrichment factor due to changes in humidity (Gat, 1970; Merlivat, 1978; Merlivat and Jouzel, 1979). However, if within a given time step lake evaporation does not exceed $\sim 25$ percent total lake volume and humidity is $<90$ percent, the isotopic evolution of an evaporating water body can be approximated by a Rayleigh relationship (Gonfiantini, 1986). Thus, we derive the partial derivative for $\delta^{18} \mathrm{O}$ and fractional lake evaporation as the first derivative of the Rayleigh equation (fig. 1):

$$
\frac{\partial\left(\delta^{18} \mathrm{O}\right)}{\partial \mathrm{F}_{\text {evap }}}=(\alpha-1)\left(\delta^{18} \mathrm{O}_{1}+1000\right)\left(1-\mathrm{F}_{\text {evap }}\right)^{(\alpha-2)}
$$


where $\alpha$ is the combined fractionation factor of the temperature-dependent equilibrium fractionation factor (Horita and Weslowski, 1994) and humidity-dependent kinetic fractionation factor (Gonfiantini, 1986), Fevap is the fraction of the lake evaporation (as above) and $\delta^{18} \mathrm{O}_{\text {initial }}$ is the initial isotopic composition of the lake from the measured $\delta^{18} \mathrm{O}$ of the biogenic carbonate corrected for vital effects (see below). While a simplification of evaporative processes, assuming a Rayleigh relationship and a combined fractionation factor in this manner has successfully been applied to both surface soil reservoir and lake system modeling (for example, Chamberlain and others, 2014; Caves and others, 2015). We assume that relative humidity for each Monte Carlo iteration can vary from 50 to 90 percent (uniform distribution), and temperature varies from 5 to $35^{\circ} \mathrm{C}$ (uniform distribution) as determined for each iteration (as described above). By doing so we calculate the combined fractionation factor, $\alpha$, using the equations of Horita and Weslowski (1994) and Gonfiantini (1986) (see fig. 1). The humidity and temperature ranges selected here are conservative and broadly apply to both illustrative lake systems used in the examples below. The relevant latitude and geographic setting of the lake system being modeled should inform the humidity and temperature ranges chosen as model input.

\section{Lake Input Partial Derivatives}

Determination of the lake input partial derivatives is similar for both trace elements and oxygen isotopes. We rely on binary mixing equations assuming that the isotopic and chemical composition of water entering the lake is sufficiently well characterized and relatively invariant (relative to the lake water). Water in terminal lakes is sufficiently evaporatively enriched relative to the input $\delta^{18} \mathrm{O}$ that in most examples, the 
input water $\delta^{18} \mathrm{O}$ composition is typically statistically distinguishable from the lake water $\delta^{18} \mathrm{O}$ composition (see for example compilation by Horton and Oze, 2012). This is similar for trace elements in terminal lake systems, such that the input concentration of $\mathrm{Sr}$ and $\mathrm{Mg}$ in terminal lakes is typically more dilute than the lake water.

Given these principles, we define the partial derivative relating increased lake volume, from the addition of source water $\left(\mathrm{F}_{\text {input }}\right.$, which varies from 1 to infinity, where 1 is the original lake volume) and variations in $\delta^{18} \mathrm{O}$ as the first derivative of a binary mixing relationship (fig. 2):

$$
\frac{\partial\left(\delta^{18} \mathrm{O}\right)}{\partial \mathrm{F}_{\text {input }}}=\frac{\left(\delta^{18} \mathrm{O}\right)_{\text {source }}-\left(\delta^{18} \mathrm{O}\right)_{\text {initial }}}{\left(\mathrm{F}_{\text {evap }}\right)^{2}}
$$

where $\delta^{18}$ Osource is the meteoric water composition and $\delta^{18} \mathrm{O}_{\text {initial }}$ is determined as previously described. The meteoric water $\delta^{18} \mathrm{O}$ composition should be determined by direct observation, by upstream fluvial carbonates (for example Ibarra and others, 2015) or by assuming an empirical relationship related to the amount of annual rainfall (amount effect), as observed in many tropical systems (Risi and others, 2008). Similarly for trace element concentrations:

$$
\frac{\partial[\mathrm{M}]}{\partial \mathrm{F}_{\text {input }}}=\frac{[\mathrm{M}]_{\text {source }}-[\mathrm{M}]_{\text {initial }}}{\left(\mathrm{F}_{\text {evap }}\right)^{2}}
$$

where $\mathrm{M}$ is the $\mathrm{Sr}$ or $\mathrm{Mg}$ concentration, $[\mathrm{M}]$ source refers to the runoff water concentrations, and $[\mathrm{M}]_{\text {initial }}$ is determined as previously described from the measured $\mathrm{Mg} / \mathrm{Ca}$ and $\mathrm{Sr} / \mathrm{Ca}$ of the biogenic carbonate. 


\section{Input Parameter Requirements}

There are several input parameter requirements that need to be satisfied for robust use of this model. First, measurements of solute chemistry $([\mathrm{Sr}],[\mathrm{Mg}]$, and $[\mathrm{Ca}]$ from lake water and/or runoff) and $\delta^{18} \mathrm{O}$ of meteoric water are necessary to constrain the mixing equation end-members. This can best be done by measuring the elemental and isotopic composition of modern rivers and precipitation in the lake to be studied or the site of the ancient lake as is done here in the Songliao Basin (table 2). There are obvious complications to this approach since the drainage basin may have changed through time as well as the isotopic composition of precipitation - for example by a change in moisture source. In addition, the uncertainty (standard deviation) of the end-members is required. This can be quantified through repeat measurements of stream water/subsurface runoff chemistry.

Second, empirical relationships for temperature effects on the species-specific partition coefficient (for $\mathrm{Mg} / \mathrm{Ca}$ ) are required; such as those fit by Engstrom and Nelson (1991) and DeDeckker and others (1999). As discussed above, species-specific vital effects for $\delta^{18} \mathrm{O}$ offsets are applied uniformly prior to derivation of the partial derivatives from the mixing and mass conservation equations. Input parameters are supplied to HyBIM as the mean and standard deviation, assuming a normal distribution. However, implementation of other probability distributions (such as uniform distributions) is possible. The probable temperature and relative humidity ranges (used for the $\delta^{18} \mathrm{O}$ equilibrium fractionation equations and $\mathrm{Mg} / \mathrm{Ca} \mathrm{K}_{\mathrm{D}}$ values), which are treated as uniform distributions, are specified by the user and should be informed by paleoenvironmental, latitudinal, climate modeling, and/or modern observations. 


\subsection{Example Applications}

We apply HyBIM to two lacustrine paleoclimate records covering differing timescales, geochemical conditions, ostracod species, and dataset resolutions (figs. 3 and 4). We chose these two data sets because: (1) they had the elemental and isotopic measurements necessary for using this model and; (2) they represent two very different cases that demonstrate the utility and flexibility and limitations of the HyBIM for a variety of biogenic carbonate paleoclimate records. In each case, the original age model is used for all datasets and input parameters are constrained using modern catchment and lake chemistry and species-specific partition coefficient calibrations. Sampling resolution, the least squares cross-validated kernel bandwidths, length of the paleoclimate record, and input parameter sources are listed in table 2.

\section{Lake Miragoane, Haiti (Hodell and others, 1991; Curtis and Hodell, 1993)}

The paleoclimate records from Holocene Lake Miragoane in Haiti (Hodell and others, 1991; Curtis and Hodell, 1993; Higuera-Gundy and others, 1999) were one of the first to use detailed, high-resolution stable isotope and trace element measurements on lacustrine ostracods. This hydrologically closed lake provides a complete record of the Holocene at high resolution (see age resolutions for $\delta^{18} \mathrm{O}, \mathrm{Mg} / \mathrm{Ca}$ and $\mathrm{Sr} / \mathrm{Ca}$ records in table 2). Two cores were recovered and sampled at fine $(\sim 10 \mathrm{~cm})$ resolution for $\delta^{18} \mathrm{O}$ and coarser $(\sim 150 \mathrm{~cm})$ resolution for $\mathrm{Mg} / \mathrm{Ca}$ and $\mathrm{Sr} / \mathrm{Ca}$ (Curtis and Hodell, 1993). The discrepancy in sample resolution results in the cross-validated kernel bandwidth for $\delta^{18} \mathrm{O}$ (bandwidth $=39$ years) to be much shorter than the $\mathrm{Mg} / \mathrm{Ca}$ and $\mathrm{Sr} / \mathrm{Ca}$ records (422 and 
440 years, respectively) (fig. 3A). Data from both cores were combined and kernel smoothed using the original age model.

The elemental and isotopic data for these studies were from ostracods identified as Candona sp., by R. Forester (see discussion in Curtis and Hodell, 1993), which is an ostracod species closely related to Candona rawsoni. See table 2 for detailed model input parameters, including the partition coefficients for Candona rawsoni as determined by Engstrom and Nelson (1991).

The modeled temperature and lake volume changes for the Lake Miragoane record are largely in accordance with the expected response (see interpretation in Curtis and Hodell, 1993, their fig. 8). These authors suggested based on the isotopic and elemental data that lake levels were highest and climate was "mesic" (wetter and hotter) during the early Holocene, peaking between 7,000 and 4,000 years BP (Hodell and others, 1991; Curtis and Hodell, 1993). In the late Holocene they suggest that between $\sim 4,000$ and $\sim 2,500$ years BP there was a two-step increase in aridity towards lower lake level and increased salinity, based primarily on the oxygen isotopes (Hodell and others, 1991), followed by wetter conditions beginning at 1,000 year BP based on additional evidence from the trace element measurements (Curtis and Hodell, 1993).

Our model agrees with this interpretation and shows that modeled temperature and lake volume covary. Lake volume and temperature increase to a peak at $~ 6300$ years BP, decline to a minimum at 2000 years BP, and increase again nearing present day. The deglacial warming $(\sim 10,000-7,000$ years BP), and increasing aridity (from $\sim 4,000$ - 1,000 years BP) are captured by the predicted temperature fluctuations. Driven by the covariation in the input datasets, the modeled temperature is substantially different than 
that expected from just using the $\frac{\partial\left(\delta^{18} \mathrm{O}\right)}{\partial \mathrm{T}}$ empirical relationship of $0.26 \%{ }^{\circ} \mathrm{C}$ (thin red line of fig. 3B; relationship derived in fig. A2). In addition, while the higher resolution $\delta^{18} \mathrm{O}$ record determines the sub-1000-year variations in temperature, the long-term trends largely reflect the trace element records. The sampling resolution discrepancy of the trace elements (low resolution) and $\delta^{18} \mathrm{O}$ records (high resolution) is not necessarily ideal, but our results demonstrate that, by kernel smoothing the records and interpolating to even time-steps, the problem of differing sampling resolution can be resolved.

\section{Songliao Basin, China (Chamberlain and others, 2013)}

The Songliao Basin is a Cretaceous terrestrial lake basin that contains up to 10,000 $\mathrm{m}$ of fluvial-lacustrine, volcaniclastic and alluvial sediments (Feng and others, 2010; Wang and others, 2013). During the first phase (SK-1) of the International Continental Scientific Drilling Project's (ICDP) efforts to recover strata covering the entire Cretaceous, a total of 2,486 m of core were recovered that span the late Turonian to the end Cretaceous (Wan and others, 2013; Deng and others, 2013; Wu and others, 2014). Recent paleoclimate reconstruction efforts have used a variety of proxies, including ostracods from lacustrine facies (Chamberlain and others, 2013) and paleosol carbonate nodules (Huang and others, 2013; Gao and others, 2015). We model the $\mathrm{Sr} / \mathrm{Ca}, \mathrm{Mg} / \mathrm{Ca}$ and $\delta^{18} \mathrm{O}$ ostracod record originally published by Chamberlain and others (2013) spanning 84 to $88 \mathrm{Ma}$ (fig. 4A). Data is kernel smoothed on the original age model (Wan and others, 2013; Wang and others, 2013; Chamberlain and others, 2013), and this portion of the record was selected because of the high density sampling through this period, relatively stable source area (based on ${ }^{87} \mathrm{Sr} /{ }^{86} \mathrm{Sr}$ ), and the likely existence of 
Ocean Anoxic Event 3 (OAE 3 at 85.5 Ma; Wagreich, 2012). Because the ostracod genus Cypridea sampled by Chamberlain and others (2013) is extinct, we use partition coefficient and vital effect calibrations for the extant genus Cyprideis, a closely related genus also of the Cyprididae family (table 2). See table 2 for detailed model input parameters.

The relatively invariant (kernel smoothed) $\mathrm{Mg} / \mathrm{Ca}$ and $\mathrm{Sr} / \mathrm{Ca}$ records (fig. 4A) result in several interesting observations when HyBIM is applied to the Songliao Basin ostracod record. The $\mathrm{Mg} / \mathrm{Ca}$ and $\mathrm{Sr} / \mathrm{Ca}$ records demonstrate much greater spread around the mean kernel-smoothed values and, due to slightly lower sampling density, have a greater cross-validated kernel bandwidth than the $\delta^{18} \mathrm{O}$ record (62 kyrs vs. 241 kyrs and 219 kyrs; fig. 4A). Because of the relatively invariant $\mathrm{Mg} / \mathrm{Ca}$ and $\mathrm{Sr} / \mathrm{Ca}$ record, the modeled temperature is similar to the result expected if a $\frac{\partial\left(\delta^{18} \mathrm{O}\right)}{\partial \mathrm{T}}$ empirical relationship of $0.58 \% /{ }^{\circ} \mathrm{C}$ is applied to the kernel smoothed mean of the $\delta^{18} \mathrm{O}$ record (red line in fig. 4B), unlike the Lake Miragoane record.

We applied the HyBIM to a portion of the Songliao record given in Chamberlain and others (2013) from 88 to 84 Ma because this time interval captures a portion of the Oceanic Anoxic Event 3 (OAE 3) during a time of global warming. Moreover, we have excellent oxygen and trace element data for this time range in the Songliao Basin. It is recognized that unlike earlier OAEs, OAE 3, may be a series of events distributed over longer time frames and is recorded predominantly in the western hemisphere (Wagreich, 2012). Thus, we are interested in how the temperature record in the Songlia Basin recorded this "event". Our results show peaks of warming of $\sim 6^{\circ} \mathrm{C}$ between 86 and 85 
Ma and again between 85 and 84 Ma. These two warm periods are consistent with multiple events defining OAE 3, but cannot be correlated with those in marine sections because: 1) the age constraints in the Songlia Basin lack the necessary time resolution; and 2) there are multiple carbon isotope excursions during OAE 3 that vary both temporally and spatially across the globe (Wagreich, 2012). Nevertheless, our results do show multiple warming events during this time interval of OAE 3. In addition, the HyBIM results agree with the interpretation of increasing lake size, based on outcrop extent, during this time interval (Feng and others, 2010), suggesting that over this interval lake volume increased by $\sim 10$ percent. However, we point out that due to the large spread in the measured $\mathrm{Sr} / \mathrm{Ca}$ and $\mathrm{Mg} / \mathrm{Ca}$, the modeled volume changes are not particularly robust.

\subsection{Limitations and Guidelines}

The modeling framework presented in this paper represents a new approach to quantitatively constraining the hydrologic balance and temperature fluctuations as recorded by the trace elements and stable isotopes of biogenic lacustrine carbonate. Inherently the modeling of paleoclimate records requires simplifying assumptions. As

such, we provide several guidelines for assessing the potential application of HyBIM to a lake system:

1. Lake systems with highly variable (inorganic) chemical sedimentation, typically driven by order of magnitude changes in lake level, cannot be modeled using HyBIM. A fundamental assumption of the evaporation partial derivatives is that we assume mass conservation of the trace elements within each time step. In 
addition, we assume that within each time step lake volume does not change by more than 10 percent (see derivation of partial derivatives). Thus, HyBIM solutions should be limited to "balanced-filled" (Caroll and Bohacs, 1999) lake systems with biogenic carbonate from periods of similar lithologic deposition.

2. Many large lakes break up into smaller lakes during desiccation due to complex hypsometric basin geometries and watersheds (for example Quaternary Lake Lahontan; Reheis and others, 2014). While this is not readily assessed from sediment cores alone, we emphasize the need for determination of the lake hypsometry via shoreline and/or outcrop extent (for example, Reheis, 1999; Sack, 2009; Zimmerman and others, 2011; Steinman and others, 2013; Ibarra and others, 2014; Smith and others, 2014; Doebbert and others, 2014). HyBIM should not be applied to these systems over intervals of breakup, as the river chemistry of the smaller lake basins within a large system may differ due to bedrock heterogeneity and catchment weathering processes.

3. Well-constrained partition coefficients are necessary to place the measured $\mathrm{Mg} / \mathrm{Ca}$ and $\mathrm{Sr} / \mathrm{Ca}$ (or other trace element measurements) in terms of lake water concentrations. Presently modern studies of terrestrial biogenic carbonates from ostracods (for example, Engstrom and Nelson, 1991; Xia and others, 1997a, 1997b; Wansard and others, 1998; De Deckker and others, 1999; Dettman and others, 2002; Holmes and Chivas, 2002; Dwyer and others, 2002; Ito and Forester, 2009; Gouramanis and others, 2010; Marco-Barba and others, 2012; Börner and others, 2013) represent some of the only calibrated partition coefficients available for use in the HyBIM modeling framework outlined here. 
Future application of this modeling framework to inorganic carbonate or other types of biogenic carbonate from lake systems will require further measurement of trace elements and calibration of partition coefficients.

4. We assume that lake water temperature and the basin average air temperature are directly proportional. HyBIM solves for temperature changes $(\Delta \mathrm{T})$, not absolute values of temperature, but selects an absolute temperature for each Monte Carlo iteration used for placing the measured $\mathrm{Mg} / \mathrm{Ca}$ and $\delta^{18} \mathrm{O}$ into lake water composition (see previous discussion). For the lake systems with mean annual air temperature greater than $0{ }^{\circ} \mathrm{C}$ included in a recent global lake temperature compilation the slope between the mean annual water temperature and mean annual surface air temperature is indistinguishable from 1 (slope $=1.02 \pm 0.03$ $(1 \sigma), r^{2}=0.94, n=81$, mean annual air temperatures from 0 to $27^{\circ} \mathrm{C}$; see dataset from Appendix A of Hren and Sheldon, 2012), suggesting that this assumption of proportionality is valid.

\subsection{Conclusions and Future Model Refinement}

In this paper, we develop and apply a new modeling framework using variations in $\delta^{18} \mathrm{O}$ and trace elements ( $\mathrm{Mg}$ and $\mathrm{Sr}$ ) measured in biogenic lacustrine carbonates for closed basin lacustrine paleoclimate records. By applying this modeling approach to two ostracod records, we demonstrate the utility of HyBIM to quantify paleoenvironmental changes across different timescales. Due to a lack of significant variation in the (kernel smoothed) $\mathrm{Mg} / \mathrm{Ca}$ and $\mathrm{Sr} / \mathrm{Ca}$ records from the Songliao Basin, the $\delta^{18} \mathrm{O}$ record primarily controls the predicted temperature fluctuations and the volume changes are minimal. 
Additionally, the Lake Miragoane results demonstrate how the combination of highresolution and low-resolution datasets are accounted for by HyBIM via kernel smoothing and interpolation to even time steps. Future application of HyBIM to a high-resolution historical record from a small, constrained terminal lake system will provide the best independent validation of this modeling methodology.

Two additions could provide further extensions to this modeling approach. First, over-determination of the A matrix by adding a fourth equation to the system of equations describing additional trace elements (such as $\mathrm{U}$ or $\mathrm{Li}$; for example Holmes and others, 1995), $\delta \mathrm{D}$ (for example Tierney and others, 2008; Feakins and others, 2014; Kirby and others, 2014) or $813 \mathrm{C}$ (controlled by similar processes described in $\mathrm{Li}$ and $\mathrm{Ku}, 1997$; Horton and Oze, 2012; Horton and others, 2015) would provide greater control on the partitioning of salinity changes due to evaporation and dilution by volumetric increases. Second, additional isotope systems, such as $\mathrm{Sr}$ or $\mathrm{Pb}$ isotopes, could be included as a fourth equation (the A matrix would be $4 \times 4$ ) and would extend the function of HyBIM to also de-convolve other possible variables, such multiple riverine inputs, rearrangement of the drainage basin, et cetera. For example, assuming different watershed source regions have different $\mathrm{Sr}$ or $\mathrm{Pb}$ isotope signatures (and also trace element concentrations and/or meteoric water $\delta^{18} \mathrm{O}$ inputs), a fourth set of partial derivatives can be derived to define the relationship between two distinct end-members. This approach could be applied to the full Songliao Basin record (lower resolution) presented in Chamberlain and others (2013), or to basins with sufficient data and known tectonic changes, such as Cenozoic basins in the western United States (for example, Davis and others, 2009; Smith and others, 2014; Doebbert and others, 2014). 
The application of this modeling framework is not limited solely to lake systems. For example, recently published speleothem records have measured $\delta^{18} \mathrm{O}, \mathrm{Mg} / \mathrm{Ca}$, and $\mathrm{Sr} / \mathrm{Ca}$, in addition to other trace elements (such as $\mathrm{U} / \mathrm{Ca}, \mathrm{Ba} / \mathrm{Ca}$ ) and isotope systems (such as $\left({ }^{234} \mathrm{U} /{ }^{238} \mathrm{U}\right.$ ) and ${ }^{87} \mathrm{Sr} /{ }^{86} \mathrm{Sr}$ ) (for example, Oster and others, 2009; Steponaitis and others, 2015). By modifying the modeling framework presented here the relative influence of temperature and vadose zone residence times (influenced by prior carbonate precipitation) on the stable isotope and trace element measurements could be quantitatively deconvolved. However, modern cave monitoring studies to assess the variability and controls on the stable isotope and trace element variations in cave drip water (for example, Fairchild and others, 2000; Musgrove and Banner, 2004; Wong and others, 2011; Oster and others, 2012a), would be necessary for calibration. Similarly, trace element and stable isotope measurements on pedogenic soil minerals and the associated soil pore water in arid soil systems (for example Amundson and others, 1996; Oster and others, 2012b; Maher and others, 2014) may provide an additional avenue for quantitative paleoclimate reconstruction using a similar modeling framework.

Finally, the Monte Carlo approach presented in this paper only includes uncertainty in the input parameters and input dataset. However, age-models in sedimentary settings, and many terrestrial paleoclimate archives, including lakes, can be highly uncertain due to sedimentation rate changes, hiatuses and a lack of dateable material (for example, Huybers and Wunsch, 2004; Blaauw and Christen, 2011). Further extension of HyBIM to include incorporation of age model uncertainty would provide added utility by including temporal uncertainty quantification of the hydrologic response to climatic events and trends recorded by the lake carbonate geochemistry. Recent work 
has included this type of Monte Carlo age model uncertainty into paleoclimate reconstructions for individual records and large paleoclimate compilations (for example, Shakun and others, 2012; Anchukaitis and Tierney, 2012; Tierney and others, 2013; Marcott and others, 2013; Steinman and others, 2014). Ultimately paleoclimate proxy modeling efforts, such as those illustrated in this paper, are only valuable if the uncertainty of the timing and magnitude of climatic changes is robustly quantified.

\subsection{Acknowledgements}

We thank Jay Quade and Byron A. Steinman for thorough and thoughtful reviews. We also thank Yuan Gao and Stephan A. Graham for discussing the Songliao Basin stratigraphy and age model, Kate Maher, Jeremy K. Caves, Sarah C. Lummis, Andreas Mulch and Andrea J. Ritch for thorough discussions and comments, and Bala Rajaratnam for discussing the Monte Carlo and kernel smoothing methods. We would like to thank Sherman Rothe-Maher for his insightful comments on the formulation of this model. Daniel E. Ibarra is partially supported by a Stanford EDGE-STEM Fellowship. The Songliao Basin drilling project was supported by the National Basic Research Program of China (2012CB822000) and the China Geological Survey. This research was supported by a National Science Foundation grant (EAR-1423967) to C. Page Chamberlain. 


\subsection{References}

Amundson, R., Chadwick, O., Kendall, C., Wang, Y., and DeNiro, M., 1996, Isotopic evidence for shifts in atmospheric circulation patterns during the late Quaternary in mid-North America: Geology, v. 24, n. 1, p. 23-26.

Anchukaitis, K. J., and Tierney, J. E., 2012, Identifying coherent spatiotemporal modes in time-uncertain proxy paleoclimate records: Climate dynamics, v. 41, n. 5-6, p. $1291-1306$.

Anderson, L., Abbott, M. B., and Finney, B. P., 2001, Holocene climate inferred from oxygen isotope ratios in lake sediments, Central Brooks Range, Alaska: Quaternary Research, v. 55, n. 3, p. 313-321.

Antevs, E. V., 1948, The Great Basin, with emphasis on glacial and postglacial times; climatic changes and pre-white man: Bulletin of the University of Utah, v. 38, p. $168-191$.

Bengtsson, L., and Malm, J., 1997, Using rainfall-runoff modeling to interpret lake level data: Journal of Paleolimnology, v. 18, n. 3, p. 235-248.

Bennett, C. E., Williams, M., Leng, M. J., Siveter, D. J., Davies, S. J., Sloane, H. J., and Wilkinson, I. P., 2011, Diagenesis of fossil ostracods: Implications for stable isotope based palaeoenvironmental reconstruction: Palaeogeography, Palaeoclimatology, Palaeoecology, v. 305, n. 1-4, p. 150-161.

Benson, L., and Paillet, F., 2002, HIBAL: A hydrologic-isotopic-balance model for application to paleolake systems: Quaternary Science Reviews, v. 21, n. 12-13, p. $1521-1539$. 
Benson, L. V., and Paillet, F. L., 1989, The use of total lake-surface area as an indicator of climatic change: Examples from the Lahontan basin: Quaternary Research, v. 32, n. 3, p. 262-275.

Benson, L. V., and White, J. W. C., 1994, Stable isotopes of oxygen and hydrogen in the Truckee River-Pyramid Lake surface-water system. 3. Source of water vapor overlying Pyramid Lake: Limnology and Oceanography, v. 39, n. 8, p. 19451958.

Binford, M. W., Kolata, A. L., Brenner, M., Janusek, J. W., Seddon, M. T., Abbott, M., and Curtis, J. H., 1997, Climate Variation and the Rise and Fall of an Andean Civilization: Quaternary Research, v. 47, n. 2, p. 235-248.

Blaauw, M., and Christen, J. A., 2011, Flexible paleoclimate age-depth models using an autoregressive gamma process: Bayesian Analysis, v. 6, n. 3, p. 457-474.

Blome, M. W., Cohen, A. S., and Lopez, M. J., 2014, Modern distribution of ostracodes and other limnological indicators in southern Lake Malawi: implications for paleocological studies: Hydrobiologia, v. 728, n. 1, p. 179-200.

Bohacs, K. M., Carroll, A. R., and Neal, J. E., 2003, Lessons from large lake systemsthresholds, nonlinearity, and strange attractors, in Chan, M. A., and Archer, A. W., editors, Extreme depositional environments: mega end members in geologic time: Geological Society of America Special Paper 370, p. 75-90.

Bowen, G. J., and Revenaugh, J., 2003, Interpolating the isotopic composition of modern meteoric precipitation: Water Resources Research, v. 39, n. 10, p. SWC91SWC913. 
Bowler, J. M., 1981, 30. Australian salt lakes - A palaeohydrologic approach: Hydrobiologia, v. 81-82, n. 1, p. 431-444.

Börner, N., De Baere, B., Yang, Q., Jochum, K. P., Frenzel, P., Andreae, M. O., and Schwalb, A., 2013, Ostracod shell chemistry as proxy for paleoenvironmental change: Quaternary International, v. 313-314, p. 17-37.

Broecker, W., 2010, Long-term water prospects in the Western United States: Journal of Climate, v. 23, n. 24, p. 6669-6683.

Burnett, A. W., Kirby, M. E., Mullins, H. T., and Patterson, W. P., 2003, Increasing Great Lake-effect snowfall during the twentieth century: A regional response to global warming?: Journal of Climate, v. 16, n. 21, p. 3535-3542.

Carroll, A. R., 1998, Upper Permian lacustrine organic facies evolution, Southern Junggar Basin, NW China: Organic Geochemistry, v. 28, n. 11, p. 649-667.

Carroll, A. R., and Bohacs, K. M., 1999, Stratigraphic classification of ancient lakes: Balancing tectonic andclimatic controls: Geology, v. 27, n. 2, p. 99-102.

Caves, J. K., Winnick, M. J., Graham, S. A., Sjostrom, D. J., Mulch, A., and Chamberlain, C. P., 2015, Role of the westerlies in Central Asia climate over the Cenozoic: Earth and Planetary Science Letters, v. 428, p. 33-43.

Chamberlain, C. P., Wan, X., Graham, S. A., Carroll, A. R., Doebbert, A. C., Sageman, B. B., Blisniuk, P., Kent-Corson, M. L., Wang, Z., and Chengshan, W., 2013, Stable isotopic evidence for climate and basin evolution of the Late Cretaceous Songliao basin, China: Palaeogeography, Palaeoclimatology, Palaeoecology, v. 385 , p. $106-124$. 
Chamberlain, C. P., Winnick, M. J., Mix, H. T., Chamberlain, S. D., and Maher, K., 2014, The impact of neogene grassland expansion and aridification on the isotopic composition of continental precipitation: Global Biogeochemical Cycles, v. 28, n. 9, p. 992-1004.

Chivas, A. R., De Deckker, P., and Shelley, J. M. G., 1986, Magnesium content of nonmarine ostracod shells: A new palaeosalinometer and palaeothermometer: Palaeogeography, Palaeoclimatology, Palaeoecology, v. 54, n. 1-4, p. 43-61.

Chivas, A. R., De Deckker, P., Wang, S. X., and Cali, J. A., 2002, Oxygen-Isotope Systematics of the Nektic Ostracod Australocypris Robusta, in Holmes, J. A., and Chivas, A. R., editors, The Ostracoda: Applications in Quaternary Research: Geophysical Monograph Series, American Geophysical Union, Washington, D. C., $13 \mathrm{p}$.

Cohen, A., Palacios-Fest, M., Negrini, R., Wigand, P., and Erbes, D., 2000, A paleoclimate record for the past 250,000 years from Summer Lake, Oregon, USA: II. Sedimentology, paleontology and geochemistry: Journal of Paleolimnology, v. 24, n. 2, p. 151-182.

Colman, S. M., Peck, J. A., Karabanov, E. B., Carter, S. J., Bradbury, J. P., King, J. W., and Williams, D. F., 1995, Continental climate response to orbital forcing from biogenic silica records in Lake Baikal: Nature, v. 378, p. 769-771.

Craig, H., and Gordon, L. I., 1965, Deuterium and oxygen 18 variations in the ocean and the marine atmosphere, in Tongiorgi, E., editor, Stable Isotopes in Oceanographic Studies and Paleotemperatures: Pisa, Consiglio Nazionale delle Riche, Laboratorio de Geologia Nucleare, p. 1-122. 
Currey, D. R., 1990, Quaternary palaeolakes in the evolution of semidesert basins, with special emphasis on Lake Bonneville and the Great Basin, U.S.A:

Palaeogeography, Palaeoclimatology, Palaeoecology, v. 76, n. 3-4, p. 189-214.

Curtis, J. H., and Hodell, D.A., 1993, An Isotopic and Trace Element Study of Ostracods from Lake Miragoane, Haiti: A 10,500 Year Record of Paleosalinity and Paleotemperature Changes in the Caribbean, in Swart, P. K., Lohmann, K. C., Mckenzie, J., and Savin, S., editors, Climate Change in Continental Isotopic records: American Geophysical Union, Geophysical Monograph 78, p. 135-152.

Danese, M., Masini, N., Biscione, M., and Lasaponara, R., 2014, Predictive modeling for preventive Archaeology: overview and case study: Central European Journal of Geosciences, v. 6, n. 1, p. 42-55.

Dansgaard, W., 1964, Stable isotopes in precipitation: Tellus, v. 16, n. 4, p. 436-468.

Davis, S. J., Mix, H. T., Wiegand, B. A., Carroll, A. R., and Chamberlain, C. P., 2009, Synorogenic evolution of large-scale drainage patterns: Isotope paleohydrology of sequential Laramide basins: American Journal of Science, v. 309, n. 7, p. 549602.

De Deckker, P., Chivas, A. R., and Shelley, J. M. G., 1999, Uptake of Mg and Sr in the euryhaline ostracod Cyprideis determined from in vitro experiments: Palaeogeography, Palaeoclimatology, Palaeoecology, v. 148, n. 1-3, p. 105-116.

Demko, T. M., Nicoll, K., Beer, J. J., Hasiotis, S. T., and Park, L. E., 2005, Mesozoic lakes of the Colorado Plateau: Field Guides, v. 6, p. 329-356. 
Deng, C. L., He, H. Y., Pan, Y. X., and Zhu, R. X., 2013, Chronology of the terrestrial Upper Cretaceous in the Songliao Basin, northeast Asia: Palaeogeography, Palaeoclimatology, Palaeoecology, v. 385, p. 44-54.

Derry, L. A., and France-Lanord, C., 1996, Neogene growth of the sedimentary organic carbon reservoir: Paleoceanography, v. 11, n. 3, p. 267-275.

Dettman, D. L., Palacios-Fest, M., and Cohen, A. S., 2002, Comment on G. Wansard and F. Mezquita, The response of ostracode shell chemistry to seasonal change in a Mediterranean freshwater spring environment: Journal of Paleolimnology, v. 27, n. 4, p. 487-491.

Doebbert, A. C., Carroll, A. R., Mulch, A., Chetel, L. M., and Chamberlain, C. P., 2010, Geomorphic controls on lacustrine isotopic compositions: Evidence from the Laney Member, Green River Formation, Wyoming: Geological Society of America Bulletin, v. 122, n. 1-2, p. 236-252.

Doebbert, A. C., Johnson, C. M., Carroll, A. R., Beard, B. L., Pietras, J. T., Rhodes Carson, M., Norsted, B., and Throckmorton, L. A., 2014, Controls on Sr isotopic evolution in lacustrine systems: Eocene Green River formation, Wyoming: Chemical Geology, v. 380, p. 172-189.

Dwyer, G. S., Cronin, T. M., and Baker, P. A., 2002, Trace Elements in Marine Ostracods, in Holmes, J. A., and Chivas, A. R., editors, The Ostracoda: Applications in Quaternary research: American Geophysical Union, Geophysical Monograph Series, v. 131, p. 205-225.

Edney, P. A., Kershaw, A. P., and De Deckker, P., 1990, A late Pleistocene and Holocene vegetation and environmental record from Lake Wangoom, Western Plains of 
Victoria, Australia: Palaeogeography, Palaeoclimatology, Palaeoecology, v. 80, n. 3-4, p. 325-343.

Engstrom, D. R., and Nelson, S. R., 1991, Paleosalinity from trace metals in fossil ostracodes compared with observational records at Devils Lake, North Dakota, USA: Palaeogeography, Palaeoclimatology, Palaeoecology, v. 83, n. 4, p. 295312.

Epanechnikov, V. A., 1969, Non-Parametric Estimation of a Multivariate Probability Density: Theory of Probability \& Its Applications, v. 14, n. 1, p. 153-158.

Eugster, H. P., and Jones, B. F., 1979, Behavior of major solutes during closed basinlakes brine evolution: American Journal of Science, v. 279, n. 6, p. 609-631.

Eugster, H. P., and Kelts, K., 1983, Lacustrine chemical sediments, in Goudie, A., and Pye, K., editors, Chemical sediments and Geomorphology: London, Academic Press, p. 321-368.

Fairchild, I. J., Borsato, A., Tooth, A. F., Frisia, S., Hawkesworth, C. J., Huang, Y., McDermott, F., and Spiro, B., 2000, Controls on trace element (Sr-Mg) compositions of carbonate cave waters: implications for speleothem climatic records: Chemical Geology, v. 166, n. 3-4, p. 255-269.

Fan, J., 2012, Design-adaptive Nonparametric Regression: Journal of the American Statistical Association, v. 87, n. 420, p. 998-1004.

Fantle, M. S., 2010, Evaluating the Ca isotope proxy: American Journal of Science, v. 310, n. 3, p. 194-230.

Feakins, S. J., Kirby, M. E., Cheetham, M. I., Ibarra, Y., and Zimmerman, S. R. H., 2014, Fluctuation in leaf wax $\mathrm{D} / \mathrm{H}$ ratio from a southern California lake records 
significant variability in isotopes in precipitation during the late Holocene: Organic Geochemistry, v. 66, p. 48-59.

Feng, Z. Q., Jia, C. Z, Xie, X. N., Shun, Z., Feng, Z. H., and Cross, T. A., 2010, Tectonostratigraphic units and stratigraphic sequences of the nonmarine Songliao basin, northeast China: Basin Research, v. 22, n. 1, p. 79-95.

Forester, R. M., 1991, Pliocene-climate history of the western United States derived from lacustrine ostracodes: Quaternary Science Reviews, v. 10, n. 2-3, p. 133-146.

Franc, ois, L. M., and Godde'ris, Y., 1998, Isotopic constraints on the Cenozoic evolution of the carbon cycle: Chemical Geology, v. 145, n. 3-4, p. 177-212.

Frogley, M. R., Griffiths, H. I., and Martens, K., 2002, Modern and Fossil Ostracods From Ancient Lakes, in Holmes, J. A., and Chivas, A. R., editors, The Ostracoda: Applications in Quaternary research: American Geophysical Union, Geophysical Monograph Series, v. 131, p. 167-184.

Gao, Y., Ibarra, D. E., Wang, C., Caves, J. K., Chamberlain, C. P., Graham, S. A., and Wu, H., 2015, Mid-latitude terrestrial climate of East Asia linked to global climate in the Late Cretaceous: Geology, v. 43, n. 4, p. 287-290.

Garnett, E. R., Andrews, J. E., Preece, R. C., and Dennis, P. F., 2004, Climatic change recorded by stable isotopes and trace elements in a British Holocene tufa: Journal of Quaternary Science, v. 19, n. 3, p. 251-262.

Gat, J. R., 1970, Environmental isotope balance of Lake Tiberias: Vienna, Austria Isotope Hydrology, 1970, Proceedings of a Symposium 9-13 March 1970, International Atomic Energy Agency, p. 109-128. 
Gat, J. R., and Matsui, E., 1991, Atmospheric water balance in the Amazon basin: An isotopic evapotranspiration model: Journal of Geophysical Research: Atmospheres, v. 96, n. D7, p. 13179-13188.

Gat, J. R., Bowser, C. J., and Kendall, C., 1994, The contribution of evaporation from the Great Lakes to the continental atmosphere: estimate based on stable isotope data: Geophysical Research Letters, v. 21, n. 7, p. 557-560.

Gibson, J. J., and Edwards, T. W. D., 2002, Regional water balance trends and evaporation-transpiration partitioning from a stable isotope survey of lakes in northern Canada: Global Biogeochemical Cycles, v. 16, n. 2, p. 10-1-10-14.

Gibson, J. J., Prepas, E. E., and McEachern, P., 2002, Quantitative comparison of lake throughflow, residency, and catchment runoff using stable isotopes: modelling and results from a regional survey of Boreal lakes: Journal of Hydrology, v. 262, n. $1-4$, p. $128-144$.

Gibson, J. J., Birks, S. J., and Yi, Y., 2015, Stable isotope mass balance of lakes: a contemporary perspective: Quaternary Science Reviews, v. 131, n. , p. 316-328.

Godde'ris, Y., and Franc,ois, L. M., 1996, Balancing the Cenozoic carbon and alkalinity cycles: Constraints from isotopic records: Geophysical Research Letters, v. 23, n. 25 , p. $3743-3746$.

Gonfiantini, R., 1986, Environmental isotopes in lake studies, in Fritz, P., and Fontes, J. Ch., editors, Handbook of Environmental Isotope Geochemistry, The Terrestrial Environment, B: Amsterdam, Elsevier, p. 113-168.

Gouramanis, C., Wilkins, D., and De Deckker, P., 2010, 6000 years of environmental changes recorded in Blue Lake, South Australia, based on ostracod ecology and 
valve chemistry: Palaeogeography, Palaeoclimatology, Palaeoecology, v. 297, n. 1, p. 223-237.

Grafenstein, von, U., Erlernkeuser, H., and Trimborn, P., 1999, Oxygen and carbon isotopes in modern fresh-water ostracod valves: assessing vital offsets and autecological effects of interest for palaeoclimate studies: Palaeogeography, Palaeoclimatology, Palaeoecology, v. 148, n. 1-3, p. 133-152.

Guay, B. E., Eastoe, C. J., Bassett, R., and Long, A., 2004, Identifying sources of groundwater in the lower Colorado River valley, USA, with 18O, D, and $3 \mathrm{H}$ : implications for river water accounting: Hydrogeology Journal, v. 14, n. 1-2, p. $146-158$.

Han, Y., and Huh, Y., 2009, A geochemical reconnaissance of the Duman (Tumen) River and the hot springs of Mt. Baekdu (Changbai): Weathering of volcanic rocks in mid-latitude setting: Chemical Geology, v. 264, n. 1-4, p. 162-172.

Hayfield, T., and Racine, J. S., 2008, Nonparametric econometrics: The np package: Journal of statistical software, v. 27, n. 5, p. 1-32.

Hendriks, A. J., Schipper, A. M., Caduff, M., and Huijbregts, M. A. J., 2012, Size relationships of water inflow into lakes: Empirical regressions suggest geometric scaling: Journal of Hydrology, v. 414-415, p. 482-490.

Higuera-Gundy, A., Brenner, M., Hodell, D. A., Curtis, J. H., Leyden, B. W., and Binford, M. W., 1999, A 10,300 14C yr Record of Climate and Vegetation Change from Haiti: Quaternary Research, v. 52, n. 2, p. 159-170. 
Hillman, A. L., Yu, J., Abbott, M. B., Cooke, C. A., Bain, D. J., and Steinman, B. A., 2014, Rapid environmental change during dynastic transitions in Yunnan Province, China: Quaternary Science Reviews, v. 98, p. 24-32.

Hodell, D. A., Curtis, J. H., Higuera-Gundy, A., Brenner, M., Jones, G. A., Binford, M. W., and Dorsey, K. T., 1991, Reconstruction of Caribbean climate change over the past 10,500 years: Nature, v. 352, n. 6338, p. 790-793.

Holmes, J. A., and Chivas, A. R., 2002, Ostracod Shell Chemistry-Overview, in Holmes, J. A., and Chivas, A. R., editors, The Ostracoda: applications in Quaternary research: American Geophysical Union, Geophysical Monograph Series, v. 131, p. 185-204.

Holmes, J. A., Street-Peffott, F. A., Ivanovich, M., and Peffott, R. A., 1995a, A late Quaternary palaeolimnological record from Jamaica based on trace-element chemistry of ostracod shells: Chemical Geology, v. 124, n. 1-2, p. 143-160.

Holmes, J. A., Street-Perrott, F. A., Heaton, T. H. E., Darbyshire, D. P. F., Davies, N. C., and Hales, P. E., 1995b, Chemical and isotopic composition of karstic lakes in Jamaica, West Indies: Hydrobiologia, v. 312, n. 2, p. 121-138.

Holmes, J. A., Zhang, J., Chen, F., and Qiang, M., 2007a, Paleoclimatic implications of an 850-year oxygen-isotope record from the northern Tibetan Plateau: Geophysical Research Letters, v. 34, n. 23.

Holmes, J. A., Darbyshire, D. P. F., and Heaton, T. H. E., 2007b, Palaeohydrological significance of late Quaternary strontium isotope ratios in a tropical lake: Chemical Geology, v. 236, n. 3-4, p. 281-290. 
Horita, J., 1990, Stable isotope paleoclimatology of brine inclusions in halite: Modeling and application to Searles Lake, California: Geochimica et Cosmochimica Acta, v. 54, n. 7, p. 2059-2073.

Horita, J., and Wesolowski, D. J., 1994, Liquid-vapor fractionation of oxygen and hydrogen isotopes of water from the freezing to the critical temperature: Geochimica et Cosmochimica Acta, v. 58, n. 16, p. 3425-3437.

Horne, D. J., Cohen, A., and Martens, K., 2002, Taxonomy, Morphology and Biology of Quaternary and Living Ostracoda, in Holmes, J. A., and Chivas, A. R., editors, The Ostracoda: Applications in Quaternary research: American Geophysical Union, Geophysical Monograph Series, v. 131, p. 5-36.

Horton, T. W., and Chamberlain, C. P., 2006, Stable isotopic evidence for Neogene surface downdrop in the central Basin and Range Province: Geological Society of America Bulletin, v. 118, n. 3-4, p. 475-490.

Horton, T. W., and Oze, C., 2012, Are two elements better than one? Dual isotope-ratio detrending of evaporative effects on lake carbonate paleoelevation proxies: Geochemistry, Geophysics, Geosystems, v. 13, n. 6.

Horton, T. W., Defliese, W. F., Tripati, A. K., and Oze, C., 2015, Evaporation induced $18 \mathrm{O}$ and $13 \mathrm{C}$ enrichment in lake systems: A global perspective on hydrologic balance effects: Quaternary Science Reviews.

Hostetler, S. W., and Benson, L. V., 1994, Stable isotopes of oxygen and hydrogen in the Truckee River-Pyramid Lake surface-water system. 2. A predictive model of 180 and 2H in Pyramid Lake: Limnology and Oceanography, v. 39, n. 2, p. 356-364. 
Hren, M. T., and Sheldon, N. D., 2012, Temporal variations in lake water temperature: Paleoenvironmental implications of lake carbonate 180 and temperature records: Earth and Planetary Science Letters, v. 337-338, n. C, p. 77-84.

Huang, C., Retallack, G. J., Wang, C., and Huang, Q., 2013, Paleoatmospheric pCO2 fluctuations across the Cretaceous-Tertiary boundary recorded from paleosol carbonates in NE China: Palaeogeography, Palaeoclimatology, Palaeoecology, v. 385, p. 95-105.

Hudson, A. M., and Quade, J., 2013, Long-term east-west asymmetry in monsoon rainfall on the Tibetan Plateau: Geology, v. 41, n. 3, p. 351-354.

Hudson, A. M., Quade, J., Huth, T. E., Lei, G., Cheng, H., Edwards, L. R., Olsen, J. W., and Zhang, H., 2015, Lake level reconstruction for 12.8-2.3ka of the Ngangla Ring Tso closed-basin lake system, southwest Tibetan Plateau: Quaternary Research, v. 83, n. 1, p. 66-79.

Huth, T., Hudson, A. M., Quade, J., Guoliang, L., and Hucai, Z., 2015, Constraints on paleoclimate from 11.5 to $5.0 \mathrm{ka}$ from shoreline dating and hydrologic budget modeling of Baqan Tso, southwestern Tibetan Plateau: Quaternary Research, v. 83 , n. 1, p. 80-93.

Huybers, P., and Wunsch, C., 2004, A depth-derived Pleistocene age model: Uncertainty estimates, sedimentation variability, and nonlinear climate change: Paleoceanography, v. 19, n. 1, 24 p.

Ibarra, D. E., Egger, A. E., Weaver, K. L., Harris, C. R., and Maher, K., 2014, Rise and fall of late Pleistocene pluvial lakes in response to reduced evaporation and 
precipitation: Evidence from Lake Surprise, California: Bulletin of the Geological Society of America, v. 126, n. 11-12, p. 1387-1415.

Ibarra, Y., Corsetti, F. A., Feakins, S. J., Rhodes, E. J., and Kirby, M. E., 2015, Fluvial tufa evidence of Late Pleistocene wet intervals from Santa Barbara, California, U.S.A.: Palaeogeography, Palaeoclimatology, Palaeoecology, v. 422, p. 36-45.

Ito, E., and Forester, F. M., 2009, Changes in continental ostracode shell chemistry; uncertainty of cause: Hydrobiologia, v. 620, n. 1, p. 1-15.

Imberger, J., and Ivey, G. N., 1991, On the nature of turbulence in a stratified fluid. Part II: Application to lakes: Journal of Physical Oceanography, v. 21, n. 5, p. 659680.

Jasechko, S., Sharp, Z. D., Gibson, J. J., Birks, S. J., Yi, Y., and Fawcett, P. J., 2013, Terrestrial water fluxes dominated by transpiration: Nature, v. 496, n. 7445, p. $347-350$.

Jasechko, S., Gibson, J. J., and Edwards, T. W. D., 2014, Stable isotope mass balance of the Laurentian Great Lakes: Journal of Great Lakes Research, v. 40, n. 2, p. 336346.

Jones, B. F., Eugster, H. P., and Rettig, S. L., 1977, Hydrochemistry of the Lake Magadi basin, Kenya: Geochimica et Cosmochimica Acta, v. 41, n. 1, p. 53-72.

Jones, M. D., and Imbers, J., 2010, Modeling Mediterranean lake isotope variability: Global and Planetary Change, v. 71, n. 3-4, p. 193-200.

Jones, M. D., Roberts, C. N., and Leng, M. J., 2007, Quantifying climatic change through the last glacial-interglacial transition based on lake isotope palaeohydrology from central Turkey: Quaternary Research, v. 67, n. 3, p. 463-473. 
Jouzel, J., Alley, R. B., Cuffey, K. M., Dansgaard, W., Grootes, P., Hoffmann, G., Johnsen, S. J., Koster, R. D., Peel, D., Shuman, C. A., Stievenard, M., Stuiver, M., and White, J., 1997, Validity of the temperature reconstruction from water isotopes in ice cores: Journal of Geophysical Research-Oceans, v. 102, n. C12, p. $26471-26487$.

Keatings, K. W., ms, 1999, The Basis for Ostracod Shell Chemistry in Palaeoclimate Reconstruction: London, England, Kingston University, Ph. D. thesis.

Kelts, K., 1988, Environments of deposition of lacustrine petroleum source rocks: an introduction: Geological Society, London, Special Publications, v. 40, p. 3-26.

Kempf, O., Blisniuk, P. M., Wang, S., Fang, X., Wrozyna, C., and Schwalb, A., 2009, Sedimentology, sedimentary petrology, and paleoecology of the monsoon-driven, fluvio-lacustrine Zhada Basin, SW Tibet: Sedimentary Geology, v. 222, n. 1-2, p. $27-41$.

Kim, S. T., and O’Neil, J. R., 1997, Equilibrium and nonequilibrium oxygen isotope effects in synthetic carbonates: Geochimica et Cosmochimica Acta, v. 61, n. 16, p. $3461-3475$.

Kirby, M. E., Feakins, S. J., Hiner, C. A., Fantozzi, J., Zimmerman, S. R. H., Dingemans, T., and Mensing, S. A., 2014, Tropical Pacific forcing of Late-Holocene hydrologic variability in the coastal southwest United States: Quaternary Science Reviews, v. 102, p. 27-38.

Koch, P. L., Clyde, W. C., Hepple, R. P., Fogel, M. L., Wing, S. L., and Zachos, J. C., 2003, Carbon and oxygen isotope records from paleosols spanning the PaleoceneEocene boundary, Bighorn Basin, Wyoming, in Wing, S. L., Gingerich, P. D., 
Schmitz, B., and Thomas, E., editors, Causes and consequences of globally warm climates in the early Paleogene: Geological Society of America Special Paper 369, p. 49-64.

Krabbenhoft, D. P., Anderson, M. P., and Bowser, C. J., 1990a, Estimating groundwater exchange with lakes: 2. Calibration of a three- dimensional, solute transport model to a stable isotope plume: Water Resources Research, v. 26, n. 10, p. 24552462.

Krabbenhoft, D. P., Bowser, C. J., Anderson, M. P., and Valley, J. W., 1990b, Estimating groundwater exchange with lakes: 1 . The stable isotope mass balance method: Water Resources Research, v. 26, n. 10, p. 2445-2453.

Lamb, H., Roberts, N., Leng, M., Barker, P., Benkaddour, A., and van der Kaars, S., 1999, Lake evolution in a semi-arid montane environment: response to catchment change and hydroclimatic variation: Journal of Paleolimnology, v. 21, n. 3, p. 325-343.

Li, G., and Elderfield, H., 2013, Evolution of carbon cycle over the past 100 million years: Geochimica et Cosmochimica Acta, v. 103, p. 11-25.

Li, G., Ji, J., Chen, J., and Kemp, D. B., 2009, Evolution of the Cenozoic carbon cycle: The roles of tectonics and $\mathrm{CO} 2$ fertilization: Global Biogeochemical Cycles, v. 23, n. 1 .

Li, H. C., and Ku, T. L., 1997, 13C-18C covariance as a paleohydrological indicator for closed-basin lakes: Palaeogeography, Palaeoclimatology, Palaeoecology, v. 133, n. $1-2$, p. $69-80$. 
Lister, G. S., Kelts, K., Zao, C. K., Yu, J.-Q., and Niessen, F., 1991, Lake Qinghai, China: closed-basin like levels and the oxygen isotope record for ostracoda since the latest Pleistocene: Palaeogeography, Palaeoclimatology, Palaeoecology, v. 84, n. $1-4$, p. $141-162$.

Liu, B., Liu, C.-Q., Zhang, G., Zhao, Z.-Q., Li, S.-L., Hu, J., Ding, H., Lang, Y.-C., and Li, X.-D., 2013, Chemical weathering under mid- to cool temperate and monsooncontrolled climate: A study on water geochemistry of the Songhuajiang River system, northeast China: Applied Geochemistry, v. 31, p. 265-278.

Maher, K., Ibarra, D. E., Oster, J. L., Miller, D. M., Redwine, J. L., Reheis, M. C., and Harden, J. W., 2014, Uranium isotopes in soils as a proxy for past infiltration and precipitation across the western United States: American Journal of Science, v. 314 , n. 4 , p. $821-857$.

Marco-Barba, J., Ito, E., Carbonell, E., and Mesquita-Joanes, F., 2012, Empirical calibration of shell chemistry of Cyprideis torosa (Jones, 1850) (Crustacea: Ostracoda): Geochimica et Cosmochimica Acta, v. 93, p. 143-163.

Marcott, S. A., Shakun, J. D., Clark, P. U., and Mix, A. C., 2013, A reconstruction of regional and global temperature for the past 11,300 years: Science, v. 339, n. 6124, p. 1198-1201.

McGee, D., Quade, J., Edwards, R. L., Broecker, W. S., Cheng, H., Reiners, P. W., and Evenson, N., 2012, Lacustrine cave carbonates: Novel archives of paleohydrologic change in the Bonneville Basin (Utah, USA): Earth and Planetary Science Letters, v. 351-352, p. 182-194. 
Melles, M., Brigham-Grette, J., Minyuk, P. S., Nowaczyk, N. R., Wennrich, V., DeConto, R. M., Anderson,

P. M., Andreev, A. A., Coletti, A., Cook, T. L., Haltia-Hovi, E., Kukkonen, M., Lozhkin, A. V., Rose'n, P., Tarasov, P., Vogel, H., and, Wagner, B., 2012, 2.8 million years of Arctic climate change from Lake El'gygytgyn, NE Russia: Science, v. 337, n. 6092, p. 315-320.

Merlivat, L., 1978, The dependence of bulk evaporation coefficients on air-water interfacial conditions as determined by the isotopic method: Journal of Geophysical Research-Oceans, v. 83, n. C6, p. 2977-2980.

Merlivat, L., and Jouzel, J., 1979, Global climatic interpretation of the deuterium-oxygen 18 relationship for precipitation: Journal of Geophysical Research-Oceans, v. 84, n. C8, p. 5029-5033.

Mifflin, M. D., and Wheat, M. M., 1979, Pluvial Lakes and Estimated Pluvial Climates of Nevada: Nevada Bureau of Mines and Geology Bulletin, v. 94, 57 p.

Moon, S., Huh, Y., and Zaitsev, A., 2009, Hydrochemistry of the Amur River: Weathering in a Northern Temperate Basin: Aquatic Geochemistry, v. 15, n. 4, p. $497-527$.

Mu“ller, G., Irion, G., and Förstner, U., 1972, Formation and diagenesis of inorganic CaMg carbonates in the lacustrine environment: Naturwissenschaften, v. 59, n. 4, p. $158-164$.

Munroe, J. S., and Laabs, B. J. C., 2013, Latest Pleistocene history of pluvial Lake Franklin, northeastern Nevada, USA: Geological Society of America Bulletin, v. 125 , n. 3-4, p. 322-342. 
Musgrove, M., and Banner, J. L., 2004, Controls on the spatial and temporal variability of vadose dripwater geochemistry: Edwards aquifer, central Texas: Geochimica et Cosmochimica Acta, v. 68, n. 5, p. 1007-1020.

Nilsson, E., 1931, Quaternary glaciations and pluvial lakes in British East Africa: Geografiska Annaler, v. 13, p. 249-349.

Oster, J. L., Montañez, I. P., Sharp, W. D., and Cooper, K. M., 2009, Late Pleistocene California droughts during deglaciation and Arctic warming: Earth and Planetary Science Letters, v. 288, n. 3-4, p. 434-443.

Oster, J. L., Montan ez, I. P., and Kelley, N. P., 2012a, Response of a modern cave system to large seasonal precipitation variability: Geochimica et Cosmochimica Acta, v. 91, p. 92-108.

Oster, J. L., Ibarra, D. E., Harris, C. R., and Maher, K., 2012b, Influence of eolian deposition and rainfall amounts on the U-isotopic composition of soil water and soil minerals: Geochimica et Cosmochimica Acta, v. 88, p. 146-166.

Oviatt, C. G., and McCoy, W. D., 1992, Early Wisconsin lakes and glaciers in the Great Basin, U.S.A, in Clark, P. U., and Lea, P. D., editors, The Last InterglacialGlacial Transition in North America: Geological Society of America Special Paper 270, p. 279-288.

Partridge, T. C., Demenocal, P. B., Lorentz, S. A., Paiker, M. J., and Vogel, J. C., 1997, Orbital forcing of climate over South Africa: A 200,000-year rainfall record from the Pretoria Saltpan: Quaternary Science Reviews, v. 16, n. 10, p. 1125-1133. 
Placzek, C. J., Quade, J., and Patchett, P. J., 2011, Isotopic tracers of paleohydrologic change in large lakes of the Bolivian Altiplano: Quaternary Research, v. 75, n. 1, p. $231-244$.

Poulsen, C. J., Pollard, D., and White, T. S., 2007, General circulation model simulation of the 180 content of continental precipitation in the middle Cretaceous: A model-proxy comparison: Geology, v. 35, n. 3, p. 199-202.

Reheis, M., 1999, Highest pluvial-lake shorelines and Pleistocene climate of the western Great Basin: Quaternary Research, v. 52, n. 2, p. 196-205.

Reheis, M. C., Adams, K. D., Oviatt, C. G., and Bacon, S. N., 2014, Pluvial lakes in the Great Basin of the western United States-a view from the outcrop: Quaternary Science Reviews, v. 97, p. 33-57.

Royer, D. L., Donnadieu, Y., Park, J., Kowalczyk, J., and Godde'ris, Y., 2014, Error analysis of $\mathrm{CO} 2$ and $\mathrm{O} 2$ estimates from the long-term geochemical model GEOCARBSULF: American Journal of Science, v. 314, n. 9, p. 1259-1283.

Rozanski, K., Aragua's-Aragua's, L., and Gonfiantini, R., 1993, Isotopic patterns in modern global precipitation, in Swart, P. K., Lohmann, K. C., McKenzie, J., and Savin, S., editors. Climate Change in Continental Isotopic Records: Washington D. C., American Geophysical Union Geophysical Monograph 78, p. 1-36.

Rozanski, K., Johnsen, S. J., Schotterer, U., and Thompson, L. G., 1997, Reconstruction of past climates from stable isotope records of palaeo-precipitation preserved in continental archives: Hydrological Sciences Journal, v. 42, n. 5, p. 725-745. 
Russell, J. M., and Johnson, T. C., 2006, The Water Balance and Stable Isotope Hydrology of Lake Edward, Uganda-Congo: Journal of Great Lakes Research, v. 32, n. 1, p. $77-90$.

Sack, D., 2009, Evidence for climate change from desert basin palaeolakes, in Parsons, A. J., and Abrahams, A. D., editors, Geomorphology of Desert Environments: Netherlands, Springer, chapter 25, p. 743-756.

Shakun, J. D., Clark, P. U., He, F., Marcott, S. A., Mix, A. C., Liu, Z., Otto-Bliesner, B., Schmittner, A., and Bard, E., 2012, Global warming preceded by increasing carbon dioxide concentrations during the last deglaciation: Nature, v. 484, n. 7392, p. 49-54.

Shapley, M. D., Ito, E., and Donovan, J. J., 2005, Authigenic calcium carbonate flux in ground water controlled lakes: Implications for lacustrine paleoclimate records: Geochimica et Cosmochimica Acta, v. 69, n. 10, p. 2517-2533.

Smith, M. E., Carroll, A. R., Jicha, B. R., Cassel, E. J., and Scott, J. J., 2014, Paleogeographic record of Eocene Farallon slab rollback beneath western North America: Geology, v. 42, n. 12, p. 1039-1042.

Snyder, C. T., and Langbein, W. B., 1962, The Pleistocene Lake in Spring Valley, Nevada, and its climatic implications: Journal of Geophysical Research, v. 67, n. 6, p. 2385-2394.

Stansell, N. D., Steinman, B. A., Abbott, M. B., Rubinov, M., and Roman-Lacayo, M., 2013, Lacustrine stable isotope record of precipitation changes in Nicaragua during the Little Ice Age and Medieval Climate Anomaly: Geology, v. 41, n. 2, p. $151-154$. 
Steinman, B. A., and Abbott, M. B., 2013, Isotopic and hydrologic responses of small, closed lakes to climate variability: Hydroclimate reconstructions from lake sediment oxygen isotope records and mass balance models: Geochimica et Cosmochimica Acta, v. 105, p. 342-359.

Steinman, B. A., Rosenmeier, M. F., Abbott, M. B., and Bain, D. J., 2010a, The isotopic and hydrologic response of small, closed-basin lakes to climate forcing from predictive models: Application to paleoclimate studies in the upper Columbia River basin: Limnology and Oceanography, v. 55, n. 6, p. 2231-2245.

Steinman, B. A., Rosenmeier, M. F., and Abbott, M. B., 2010b, The isotopic and hydrologic response of small, closed-basin lakes to climate forcing from predictive models: Simulations of stochastic and mean-state precipitation variations: Limnology and Oceanography, v. 55, n. 6, p. 2246-2261.

Steinman, B. A., Abbott, M. B., Mann, M. E., Stansell, N. D., and Finney, B. P., 2012, 1,500 year quantitative reconstruction of winter precipitation in the Pacific Northwest: Proceedings of the National Academy of Sciences of the United States of America, v. 109, n. 29, p. 11619-11623.

Steinman, B. A., Abbott, M. B., Nelson, D. B., Stansell, N. D., Finney, B. P., Bain, D. J., and Rosenmeier, M. F., 2013, Isotopic and hydrologic responses of small, closed lakes to climate variability: Comparison of measured and modeled lake level and sediment core oxygen isotope records: Geochimica et Cosmochimica Acta, v. 105 , p. $455-471$.

Steinman, B. A., Abbott, M. B., Mann, M. E., Ortiz, J. D., Feng, S., Pompeani, D. P., Stansell, N. D., Anderson, L., Finney, B. P., and Bird, B. W., 2014, Ocean- 
atmosphere forcing of centennial hydroclimate variability in the Pacific Northwest: Geophysical Research Letters, v. 41, n. 7, p. 2553-2560.

Steponaitis, E., Andrews, A., McGee, D., Quade, J., Hsieh, Y.-T., Broecker, W. S., Shuman, B. N., Burns, S. J., and Cheng, H., 2015, Mid-Holocene drying of the U.S. Great Basin recorded in Nevada speleothems: Quaternary Science Reviews, v. 127 , p. $174-185$.

Talbot, M. R., 1990, A review of the palaeohydrological interpretation of carbon and oxygen isotopic ratios in primary lacustrine carbonates: Chemical Geology: Isotope Geoscience Section, v. 80, n. 4, p. 261-279.

Tierney, J. E., Russell, J. M., Huang, Y., Damste', J. S. S., Hopmans, E. C., and Cohen, A. S., 2008, Northern hemisphere controls on tropical southeast African climate during the past 60,000 years: Science, v. 322, n. 5899, p. 252-255.

Tierney, J. E., Smerdon, J. E., Anchukaitis, K. J., and Seager, R., 2013, Multidecadal variability in East African hydroclimate controlled by the Indian Ocean.: Nature, v. 493, n. 7432, p. 389-392.

Wagreich, M., 2012, “OAE 3" - Regional Atlantic organic carbon burial during the Coniacian-Santonian: Climate of the Past, v. 8, n. 5, p. 1447-1455.

Wan, X., Zhao, J., Scott, R. W., Wang, P., Feng, Z., Huang, Q., and Xi, D., 2013, Late Cretaceous stratigraphy, Songliao Basin, NE China: SK1 cores: Palaeogeography, Palaeoclimatology, Palaeoecology, v. 385, p. 31-43.

Wang, B., Lee, X.-Q., Yuan, H.-L., Zhou, H., Cheng, H.-G., Cheng, J.-Z., Zhou, Z.-H., Xing, Y., Bin Fang, Zhang, L.-K., and Yang, F., 2012, Distinct patterns of chemical weathering in the drainage basins of the Huanghe and Xijiang River, 
China: Evidence from chemical and Sr-isotopic compositions: Journal of Asian Earth Sciences, v. 59, n. C, p. 219-230.

Wang, C., Feng, Z., Zhang, L., Huang, Y., Cao, K., Wang, P., and Zhao, B., 2013, Cretaceous paleogeography and paleoclimate and the setting of SKI borehole sites in Songliao Basin, northeast China: Palaeogeography, Palaeoclimatology, Palaeoecology, v. 385, p. 17-30.

Wansard, G., De Deckker, P., and Julia`, R., 1998, Variability in ostracod partition coefficients $\mathrm{D}(\mathrm{Sr})$ and $\mathrm{D}(\mathrm{Mg})$ : Chemical Geology, v. 146, n. 1-2, p. 39-54.

Williams, D. F., Peck, J., Karabanov, E. B., Prokopenko, A. A., Kravchinsky, V., King, J., and Kuzmin, M. I., 1997, Lake Baikal Record of Continental Climate Response to Orbital Insolation During the Past 5 Million Years: Science, v. 278, n. 5340, p. 1114-1117.

Winnick, M. J., Chamberlain, C. P., Caves, J. K., and Welker, J. M., 2014, Quantifying the isotopic "continental effect": Earth and Planetary Science Letters, v. 406, p. $123-133$.

Wong, C. I., Banner, J. L., and Musgrove, M., 2011, Seasonal dripwater $\mathrm{Mg} / \mathrm{Ca}$ and $\mathrm{Sr} / \mathrm{Ca}$ variations driven by cave ventilation: Implications for and modeling of speleothem paleoclimate records: Geochimica et Cosmochimica Acta, v. 75, $\mathrm{n}$. 12, p. 3514-3529.

Wu, H., Zhang, S., Hinnov, L. A., Jiang, G., Yang, T., Li, H., Wan, X., and Wang, C., 2014, Cyclostratigraphy and orbital tuning of the terrestrial upper SantonianLower Danian in Songliao Basin, northeastern China: Earth and Planetary Science Letters, v. 407, p. 82-95. 
Xia, J., Ito, E., and Engstrom, D. R., 1997a, Geochemistry of ostracode calcite: Part 1. An experimental determination of oxygen isotope fractionation: Geochimica et Cosmochimica Acta, v. 61, n. 2, p. 377-382.

Xia, J., Engstrom, D. R., and Ito, E., 1997b, Geochemistry of ostracode calcite: Part 2. The effects of water chemistry and seasonal temperature variation on Candona rawsoni: Geochimica et Cosmochimica Acta, v. 61, n. 2, p. 383-391.

Zhang, J., Holmes, J. A., Chen, F., Qiang, M., Zhou, A., and Chen, S., 2009, An 850-year ostracod-shell trace-element record from Sugan Lake, northern Tibetan Plateau, China: Implications for interpreting the shell chemistry in high- $\mathrm{Mg} / \mathrm{Ca}$ waters: Quaternary International, v. 194, n. 1-2, p. 119-133.

Zimmerman, S. R. H., Hemming, S. R., Hemming, N. G., Tomascak, P. B., and Pearl, C., 2011, Highresolution chemostratigraphic record of late Pleistocene lake-level variability, Mono Lake, California: Geological Society of America Bulletin, v. 123 , n. 11-12, p. 2320-2334. 


\subsection{Tables}

Table 1. Definition of model parameters for HyBIM as used in the text

\begin{tabular}{|c|c|}
\hline Parameter & Description \\
\hline $\mathrm{dT}, \partial \mathrm{T}$ & $\begin{array}{l}\text { Change in basin air temperature (mean annual surface } \\
\text { temperature) }\end{array}$ \\
\hline $\mathrm{dF}_{\text {evap }}, \partial \mathrm{F}_{\text {evap }}$ & $\begin{array}{l}\text { Change in amount of lake water (volumetrically) evaporated, } \\
\text { where } F_{\text {evap }}=1 \text { is fully evaporated and } F_{\text {evap }}=0 \text { is no } \\
\text { evaporation }\end{array}$ \\
\hline $\mathrm{dF}_{\text {input }}, \partial \mathrm{F}_{\text {input }}$ & $\begin{array}{l}\text { Change in volumetric increase in lake water, where } F_{\text {input }}=1 \text { is } \\
\text { no change }\end{array}$ \\
\hline$\Delta \mathrm{t}$ & Time step of model \\
\hline$\tau_{\text {res }}$ & Residence time of lake water \\
\hline$\alpha$ & $\begin{array}{l}\text { Combined fractionation factor for Rayleigh equation (kinetic and } \\
\text { equilibrium) }\end{array}$ \\
\hline $\begin{array}{l}\mathrm{d}\left(\delta^{18} \mathrm{O}\right) \\
\partial\left(\delta^{18} \mathrm{O}\right)\end{array}$ & Change in oxygen isotopic composition of lake water \\
\hline$\left(\delta^{18} \mathrm{O}\right)_{\text {source }}$ & Oxygen isotopic composition of incoming meteoric water \\
\hline$\left(\delta^{18} \mathrm{O}\right)_{\text {initial }}$ & $\begin{array}{l}\text { Oxygen isotopic composition of lake water for a given time step, } \\
\text { derived from the measured } \delta^{18} \mathrm{O} \text { in biogenic carbonate, corrected } \\
\text { for vital effects }\end{array}$ \\
\hline $\mathrm{Sr} / \mathrm{Ca}$ & Strontium to calcium ratio measured in biogenic carbonate \\
\hline $\mathrm{Mg} / \mathrm{Ca}$ & Magnesium to calcium ratio measured in biogenic carbonate \\
\hline $\mathrm{d}[\mathrm{Sr}], \partial[\mathrm{Sr}]$ & Change in strontium concentration of lake water \\
\hline $\mathrm{d}[\mathrm{Mg}], \partial[\mathrm{Mg}]$ & Change in magnesium concentration of lake water \\
\hline $\mathrm{d}[\mathrm{M}], \partial[\mathrm{M}]$ & Change in magnesium or strontium concentration of lake water \\
\hline$[\mathrm{M}]_{\text {source }}$ & $\begin{array}{l}\text { Magnesium or strontium concentration of incoming meteoric } \\
\text { water (weighted stream water and rainwater) }\end{array}$ \\
\hline$[\mathrm{M}]_{\text {initial }}$ & $\begin{array}{l}\text { Magnesium or strontium concentration of lake water for a given } \\
\text { time step, derived from the measured } \mathrm{Sr} / \mathrm{Ca} \text { and } \mathrm{Mg} / \mathrm{Ca} \text { in } \\
\text { biogenic carbonate using the appropriate partition coefficient and } \\
\text { calcium concentration. }\end{array}$ \\
\hline $\mathrm{K}_{\mathrm{D}}[\mathrm{M}]$ & Partition coefficient for $\mathrm{Sr} / \mathrm{Ca}$ or $\mathrm{Mg} / \mathrm{Ca}$ \\
\hline
\end{tabular}


Table 2. Details of input dataset and input parameters for HyBIM application to Lake Miragoane and Songliao Basin

\begin{tabular}{|c|c|c|c|c|c|c|c|c|}
\hline Record & Age Range & Original References & $\begin{array}{l}\delta^{18} \mathrm{O} \\
\text { Average } \\
\text { Resoluti } \\
\text { on } \\
\end{array}$ & $\begin{array}{l}\mathrm{Mg} / \mathrm{Ca} \\
\text { Average } \\
\text { Resoluti } \\
\text { on } \\
\end{array}$ & $\begin{array}{l}\mathrm{Sr} / \mathrm{Ca} \\
\text { Average } \\
\text { Resoluti } \\
\text { on }\end{array}$ & $\begin{array}{l}\delta^{18} \mathrm{O} \\
\text { Kernel } \\
\text { Bandwid } \\
\text { th }\end{array}$ & $\begin{array}{l}\mathrm{Mg} / \mathrm{Ca} \text { Kernel } \\
\text { Bandwidth } \\
\end{array}$ & $\begin{array}{l}\text { Sr/Ca Kernel } \\
\text { Bandwidth }\end{array}$ \\
\hline $\begin{array}{l}\text { Lake } \\
\text { Miragoane, } \\
\text { Haiti }\end{array}$ & $\begin{array}{l}\text { Holocene } \\
(10.56-0.05 \mathrm{ka} \\
\mathrm{BP})\end{array}$ & $\begin{array}{l}\text { Hodell and others } \\
\text { (1991); Curtis and } \\
\text { Hodell (1993) }\end{array}$ & $\begin{array}{c}16.9 \\
\text { years }\end{array}$ & $\begin{array}{l}176.5 \\
\text { years }\end{array}$ & $\begin{array}{l}173.5 \\
\text { years }\end{array}$ & $\begin{array}{c}38.9 \\
\text { years }\end{array}$ & 422.6 years & 440.1 years \\
\hline $\begin{array}{l}\text { Songliao } \\
\text { Basin, China }\end{array}$ & $\begin{array}{l}\text { Cretaceous } \\
(88.04-84.02 \mathrm{Ma})\end{array}$ & $\begin{array}{l}\text { Chamberlain and } \\
\text { others (2013) }\end{array}$ & 24.4 kyrs & 27.9 kyrs & 27.9 kyrs & 61.7 kyrs & 240.9 kyrs & 219.0 kyrs \\
\hline Record & Ostracod Genus & Partition Coeff & ient & Vital & Effect & Input Soll & ite Concentrations & Input $\delta^{18} \mathrm{O}$ \\
\hline $\begin{array}{l}\text { Lake } \\
\text { Miragoane, } \\
\text { Haiti }\end{array}$ & $\begin{array}{l}\text { Candona genus } \\
\text { (identified by R. } \\
\text { Forester, see } \\
\text { details in Curtis } \\
\text { and Hodell, 1993) }\end{array}$ & \multicolumn{2}{|c|}{$\begin{array}{l}\text { As determined for Candona } \\
\text { rawsoni by Engstrom and } \\
\text { Nelson }(1991) \text {. Temperature } \\
\text { effect for } \mathrm{Mg} / \mathrm{Ca} \text { only. }\end{array}$} & \multicolumn{2}{|c|}{$\begin{array}{l}+2.5 \pm 0.2 \% \text { based } \\
\text { on Candona candida. } \\
\text { (Keatings, 1999) }\end{array}$} & \multicolumn{2}{|c|}{$\begin{array}{l}\text { Average of watershed [Sr] } \\
\text { and }[\mathrm{Mg}], \text { and lake }[\mathrm{Ca}] \text { from } \\
\text { Holmes and others }(1995 \mathrm{a}, \mathrm{b})\end{array}$} & $\begin{array}{l}-8 \pm 2 \% \\
\text { (OIPC; } \\
\text { Bowen and } \\
\text { Revenaugh, } \\
2003 \text { ) }\end{array}$ \\
\hline $\begin{array}{l}\text { Songliao } \\
\text { Basin, China }\end{array}$ & $\begin{array}{l}\text { Sampled extinct } \\
\text { Cypridea genus, } \\
\text { closely related to } \\
\text { extant genus } \\
\text { Cyprideis }\end{array}$ & \multicolumn{2}{|c|}{$\begin{array}{l}\text { As determined for Cyprideis by } \\
\text { DeDeckker and others (1999). } \\
\text { Temperature effect for both } \\
\text { Sr/Ca and } \mathrm{Mg} / \mathrm{Ca} \text {. }\end{array}$} & $\begin{array}{l}\text { Assumed } \\
0.2 \% \text { (A) } \\
\text { compilatic } \\
\text { Holmes ar } \\
2002)\end{array}$ & $\begin{array}{l}\text { be } 1.3 \pm \\
\text { erage of } \\
\text { in } \\
\text { d Chivas, }\end{array}$ & \multicolumn{2}{|c|}{$\begin{array}{l}\text { Average of watershed [Sr] } \\
\text { and [Mg], and lake [Ca] from } \\
\text { Han and Huh (2009), Wang } \\
\text { and others (2012), Liu and } \\
\text { others, (2013), Moon and } \\
\text { others (2009) }\end{array}$} & $\begin{array}{l}-18 \pm 2 \% \\
\text { (estimated } \\
\text { from Poulsen } \\
\text { and others, } \\
\text { 2007) }\end{array}$ \\
\hline
\end{tabular}




\subsection{Figures}

Figure 1. Illustration of evaporation relationships used to parameterize the partial derivatives. Inset plots show regions of linear approximation assuming Fevap $<0.2$ within each time step gray shading. Dashed lines are uncertainty. See text for equations describing relationships. (A) Rayleigh evaporation of $\delta^{18} \mathrm{O}$, total (kinetic and equilibrium) fractionation, $\varepsilon$, is $13.5+4.7 /-3.6 \%$ ( $5-35{ }^{\circ} \mathrm{C}$ and $50-90 \%$ humidity). (B) Mass conservation of solute, $\mathrm{M}$ (that is, $\mathrm{Mg}$ or $\mathrm{Sr}$ ), with an initial lake concentration of $10 \pm 2$ mmol.
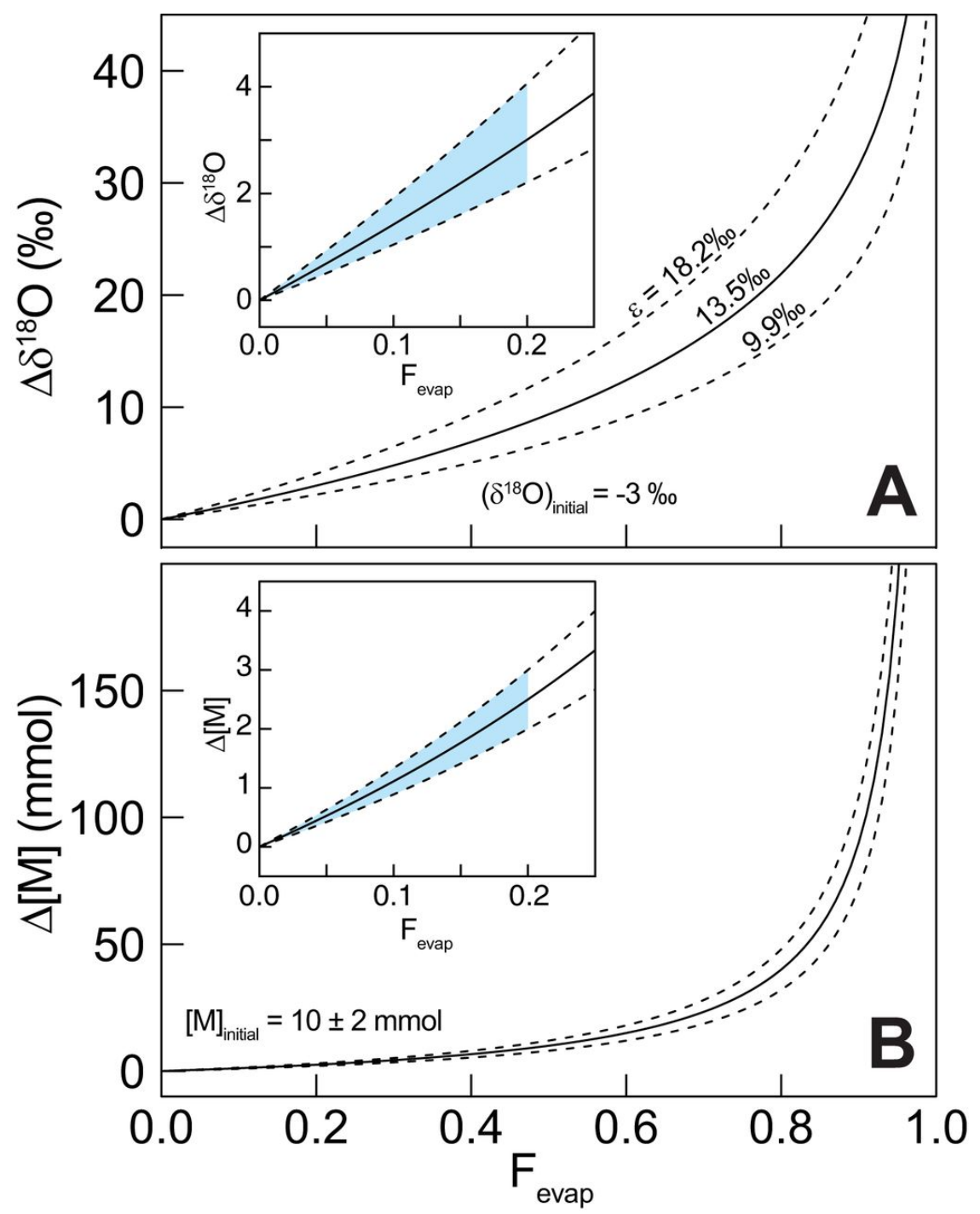
Figure 2. Illustration of mixing relationships used to parameterize the partial derivatives for volume increase. Inset plots show regions of linear approximation assuming Finput $<1.2$ within each time step. Dashed lines are uncertainty. See text for equations describing relationships. (A) $\delta^{18} \mathrm{O}$ mixing (input water of $-15 \pm 2 \%$, initial lake water of $-3 \%$ ). (B) Mixing of initial concentration $(10 \pm 2 \mathrm{mmol})$ with a dilute input solute concentration of $3 \mathrm{mmol}$.

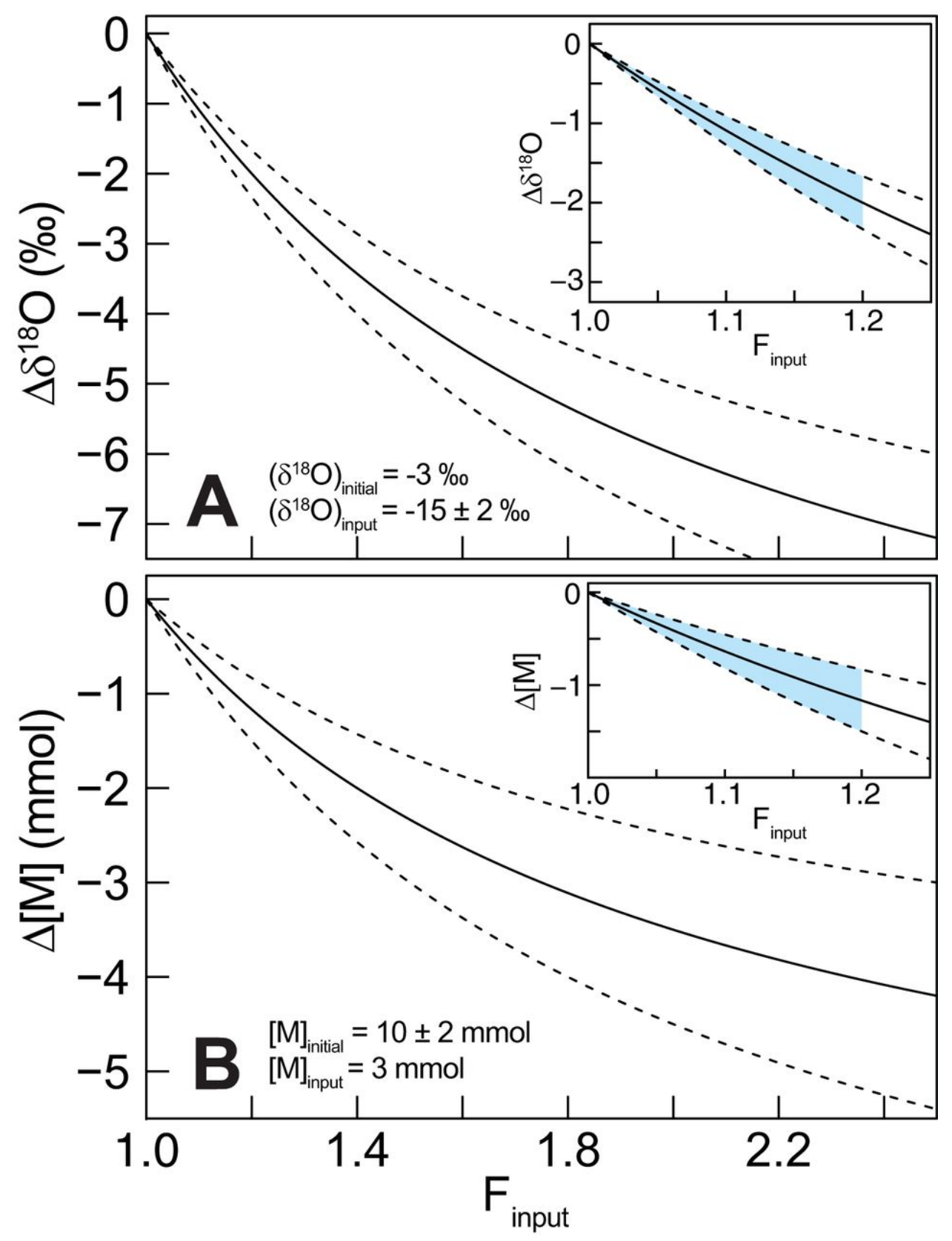


Figure 3. Illustrative Application of HyBIM to the Lake Miragoane Ostracod (Candona sp.) record. (A) Original $\delta^{18} \mathrm{O}, \mathrm{Mg} / \mathrm{Ca}$ and $\mathrm{Sr} / \mathrm{Ca}$ records (gray dots) from Hodell and others (1991) and Curtis and Hodell (1993). Data are plotted on the original age model. For model input the data are kernel smoothed using an Epanechnikov kernel. The cross validated bandwidth (BW; see text for explanation) is listed for each record $\left(\delta^{18} \mathrm{O}, \mathrm{Mg} / \mathrm{Ca}\right.$ and $\mathrm{Sr} / \mathrm{Ca}$ ). The solid black line is the mean and the dashed black lines (dashed blue lines) are the $1 \sigma$. (B) HyBIM results for the Lake Miragoane records using partition coefficient and vital effect data from Engstrom and Nelson (1991) and Keatings (ms, 1999) derived for Candona sp. The thin gray line (thin red line) is the empirical relationship for isotopes in precipitation $\left(0.26 \% /{ }^{\circ} \mathrm{C}\right)$ derived from empirical tropical GNIP stations (fig. A2; after Rozanski and others, 1993).
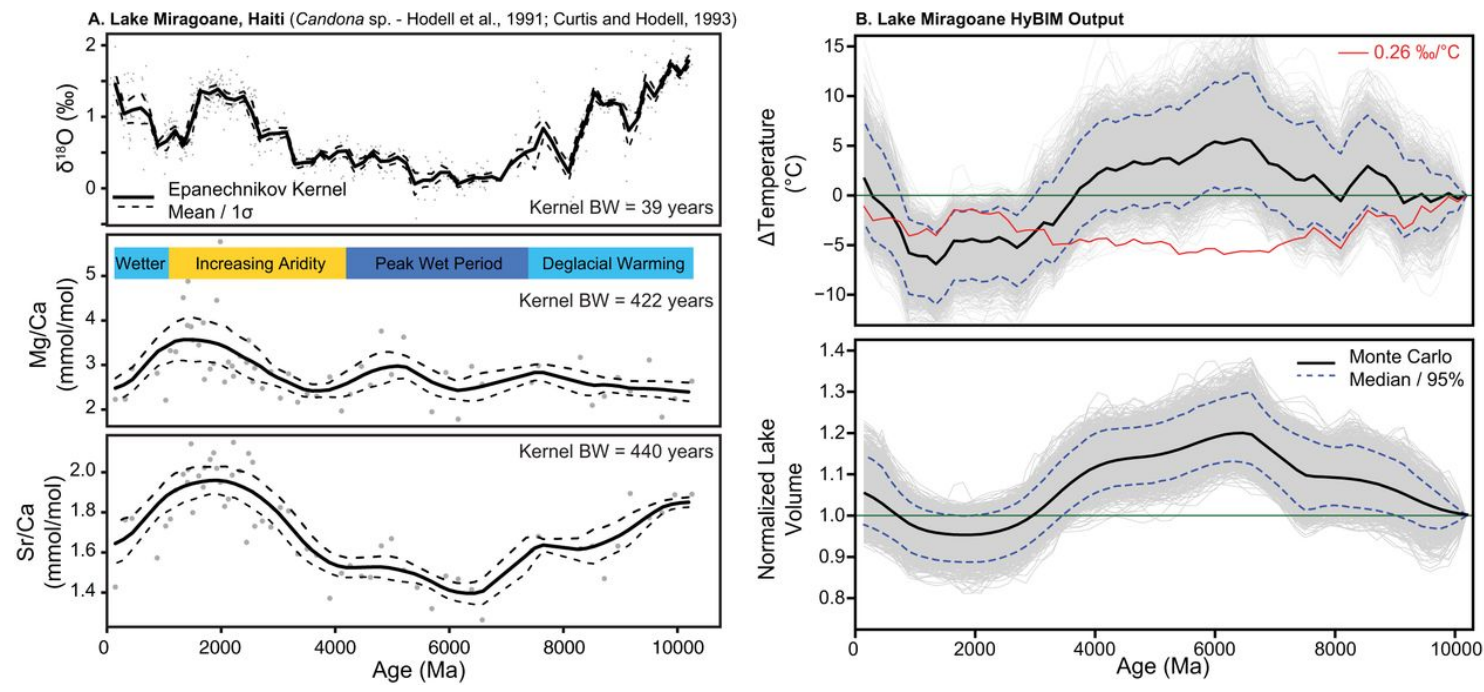
Figure 4. Illustrative Application of HyBIM to the Songliao Basin Ostracod (Cypridea sp.) Record. (A) Original $\delta^{18} \mathrm{O}, \mathrm{Mg} / \mathrm{Ca}$ and $\mathrm{Sr} / \mathrm{Ca}$ records (gray dots) from Chamberlain and others (2013). Data are plotted on the original age model of Wan and others (2013). For model input the data are kernel smoothed using an Epanechnikov kernel from 84 to $88 \mathrm{Ma}$ (densely sampled portion of the record). The cross validated bandwidth (BW; see text for explanation) is listed for each record $\left(\delta^{18} \mathrm{O}, \mathrm{Mg} / \mathrm{Ca}\right.$ and $\left.\mathrm{Sr} / \mathrm{Ca}\right)$. The solid black line is the mean and the dashed black lines are the $1 \sigma .(\mathrm{B})$ HyBIM results for the Songliao Basin record using partition coefficient data from DeDeckker and others (1999) derived for Cyprideis sp., the extant, closely related genus of Cypridea sp. The solid line is the median and the dashed black lines (dashed blue lines) are the $95 \%$ confidence interval of the Monte Carlo estimation. The approximate position of OAE 3 is denoted by the red bar, which corresponds to a peak the predicted temperature. The light gray line (red line) is the empirical relationship of Rozanski and others (1993) for isotopes in precipitation $\left(0.58 \% /{ }^{\circ} \mathrm{C}\right)$ derived from mid-latitude Global Network of Isotopes in Precipitation (GNIP) stations.
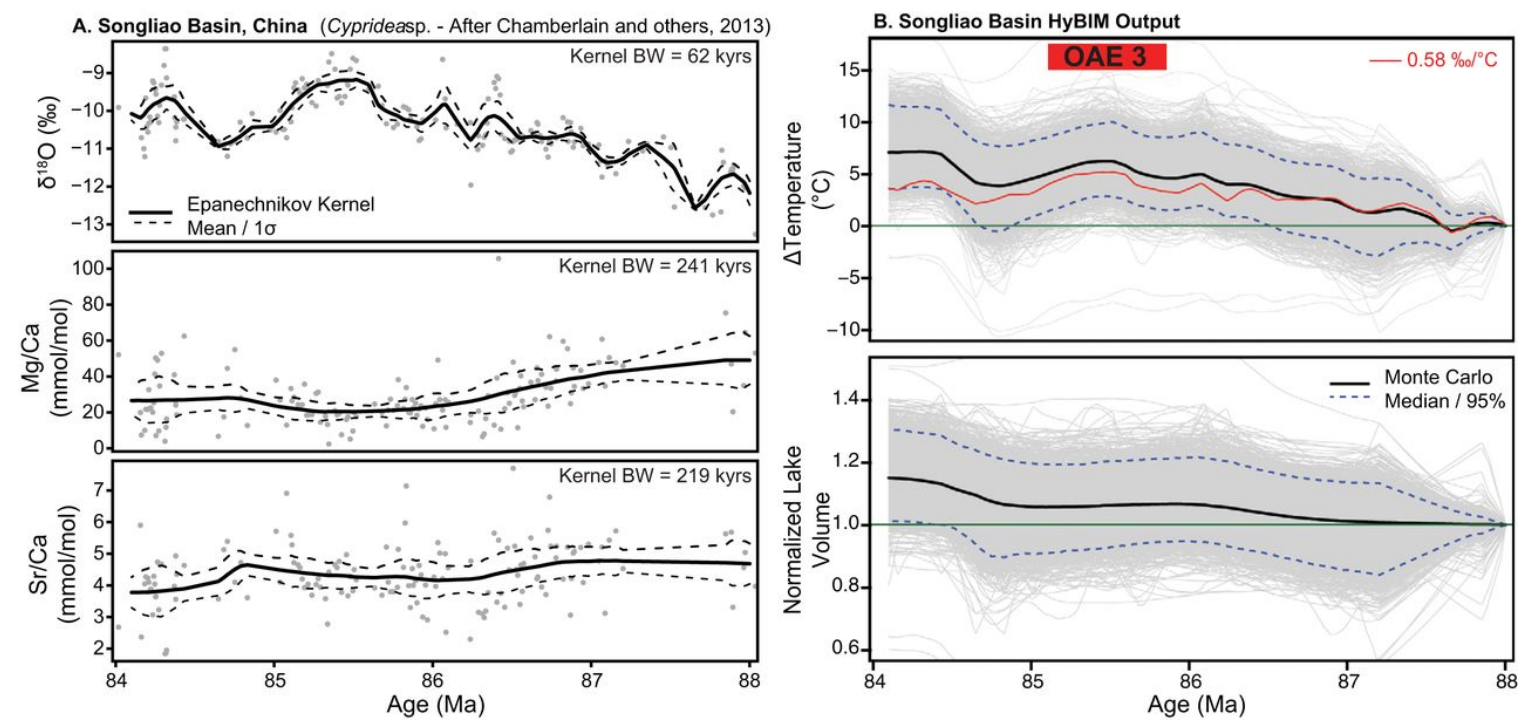


\section{CHAPTER 2}

\section{Warm and cold wet states in the western United States during the Pliocene-Pleistocene}

Daniel E. Ibarra ${ }^{1}$, Jessica L. Oster ${ }^{2}$, Matthew J. Winnick ${ }^{3}$, Jeremy K. Caves Rugenstein ${ }^{1,4}$, Michael P. Byrne $e^{5,6}$ and C. Page Chamberlain ${ }^{1}$

${ }^{1}$ Department of Earth System Science, Stanford University, Stanford, California 94305, USA

${ }^{2}$ Department of Earth and Environmental Sciences, Vanderbilt University, Nashville, Tennessee 37240, USA

${ }^{3}$ Department of Geological Sciences, Stanford University, Stanford, California 94305 USA

${ }^{4}$ Department of Earth Sciences ETH Zürich, 8092 Zürich, Switzerland

${ }^{5}$ Institute for Atmospheric and Climate Science, Department of Environmental Systems Science, ETH Zürich, 8092 Zürich, Switzerland

${ }^{6}$ Space and Atmospheric Physics Group, Department of Physics, Imperial College London, London SW7 2AZ, UK 
Reproduced with permission from Ibarra, D.E., Oster, J.L., Winnick, M.J., Caves

Rugenstein, J.K., Byrne, M.P., Chamberlain, C.P., Geology. Copyright 2018, Geological Society of America.

Licensed under the Creative Commons Attribution-NonCommercial 3.0 http://creativecommons.org/licenses/by-nc/3.0 


\begin{abstract}
The size distribution of lakes records the competition between precipitation delivery and evaporation. Lakes were abundant in the terminally draining basins of the western United States (USA) during both the colder-than-preindustrial latest Pleistocene glacial period (ca. 14-29 ka) and the warmer-than-preindustrial mid-Pliocene (ca. 2.9-3.3 Ma). To understand the hydroclimatic conditions that permitted lakes, we couple lake mass balance equations with a water and energy balance framework (sensu Budyko). Further, we compare paleo-lake area distributions to forward-modeled lake areas using climate model simulations of the Last Glacial Maximum (LGM, 19-26 ka) and midPliocene. We conclude that both warmer- and colder-than-modern periods of the Pliocene-Pleistocene resulted in wetter-than-modern conditions in the terminally draining basins of the western USA through similar mechanisms. Specifically, the presence of lakes during the LGM reflects increased precipitation in addition to decreased evaporative demand. In the southern Great Basin, LGM lakes require large increases in precipitation across the region. During the mid-Pliocene, increased evaporative demand necessitated increased precipitation to maintain lakes. Further, the increase in precipitation and dominantly southwestern distribution of mid-Pliocene lake deposits is consistent with proposed mean "El Niño-like" conditions altering regional hydroclimate during this period. These observations suggest that during interglacial periods, the western USA resides within a local aridity maximum, and both long-term increases and decreases in global temperatures have been associated with wetter conditions across much of the western USA in the past.
\end{abstract}




\subsection{Introduction}

The presence and size of lakes reflects the balance between moisture delivery and evaporative demand. Mid-latitude regions, such as the western United States (USA), exhibit evidence of large lake-level fluctuations during the Pliocene-Pleistocene in underfilled to balance-filled basins (Benson et al., 1990; Reheis et al., 2014; Pound et al., 2014). Barring large changes in rates of potential accommodation (i.e., tectonics), these fluctuations reflect changes in climate that control water and sediment supply to each basin's termini (cf. Carroll and Bohacs, 1999). Lacustrine deposits and paleo-shorelines

found throughout the terminally draining (closed) basins of the western USA (Mifflin and Wheat, 1979; Reheis et al., 2014; Pound et al., 2014) suggest a hydrologic balance dramatically different from that of the present during intervals of the PliocenePleistocene (Matsubara and Howard, 2009; Ibarra et al., 2014; Oster et al., 2015; Barth et al., 2016; Putnam and Broecker, 2017).

We compile observations of lake presence and extent during the Last Glacial Maximum (LGM) and the mid-Pliocene. To understand what hydroclimatic factors controlled lake extents during these two periods, we use a framework that enforces mass and energy balance on precipitation-runoff relationships. We compare observations of the distributions of basin area-normalized lake areas to scaling of modern climatological distributions and climate model simulations. 


\subsection{Methodology}

\section{Compilation of Geologic Observations}

We compile lake distributions for the LGM and mid-Pliocene in the western USA along with hydroclimate-sensitive proxies from previous studies (Dowsett et al., 1994; Molnar and Cane, 2007; Winnick et al., 2013; Oster et al., 2015) (Fig. 1). For the LGM, we use maps and tables of pluvial lake extent during the end of the last glacial cycle (ca. 14-29 ka; Fig. 1A; see Table DR1 in the GSA Data Repository). Because terminally draining basin areas have not significantly shifted since the LGM (e.g., Benson et al., 1990; Reheis et al., 2014), we directly compare surface area estimates. Basin areas were derived from modern watersheds using the HydroSHEDS mapping product (http://www.hydrosheds.org). We also account for shoreline geochronology that has demonstrated that lakes in the northern Great Basin (GB) reached maximum levels after the LGM, with LGM lake levels (stillstands) covering $\sim 50 \%-75 \%$ of their maximum areas (Benson et al., 1990; Ibarra et al., 2014; Reheis et al., 2014).

Pound et al. (2014) compiled the spatial distribution and estimated size of lakes during the mid-Pliocene warm period (defined as ca. 2.9-3.3 Ma for climate model simulations; Fig. 1B) within the chronostratigraphically defined Late Pliocene (Piacenzian; 2.58-3.6 Ma), which we pair with modern drainage areas only in cases where the lake was terminal and drainage divides have not been greatly influenced by major tectonic drainage reconfiguration processes (see the Data Repository, and Table DR3 therein). Their lake size compilation is largely based on mapping and fish genetics work in Southern California and southwestern Nevada, and other documented outcrops of Pliocene lacustrine sediments. Given that structural basin configurations are mostly 
unchanged since the Pliocene, it is possible that lakes filled the terminally draining basins in the GB during the late Pliocene. As supporting evidence for lake presence, we also conduct a search for 2.9-3.3 Ma strata in the Macrostrat platform (https://macrostrat.org/). We identify lacustrine strata that overlapped this range with sufficient thickness ( $>10 \mathrm{~m}$ of sedimentation) to indicate a possible long-lived lake system (Fig. 1B). Tectonic and drainage capture processes may have influenced basin boundaries since the Pliocene, introducing potential uncertainties in quantitative comparisons; however, we note that the presence of lakes in terminally draining regions indicates a hydrologic balance wetter than modern.

\section{Lake Areas and Hydroclimate Changes}

We combine a water and energy balance model with climate variables to forward model lake areas. We extend a framework proposed by Broecker (2010) by combining the commonly used basin area-normalized mass balance (cf. the pluvial hydrologic index of Mifflin and Wheat [1979]) with a Budyko framework (cf. Broecker, 2010; Greve et al., 2015) to determine changes in precipitation-runoff scaling. For a terminally draining basin, the steady-state water balance (Mifflin and Wheat, 1979; Broecker, 2010; Ibarra et al., 2014) is:

$$
\mathrm{Pk}_{\text {run }}\left(A_{B}-A_{L}\right)+P A_{L}=E_{L} A_{L},
$$

where $\mathrm{P}$ is precipitation, krun is a coefficient that determines the fraction of $\mathrm{P}$ converted to runoff, $\mathrm{A}$ is area (subscripts: $\mathrm{B}$ - terminal basin area, $\mathrm{L}$-lake area), and $\mathrm{E}_{\mathrm{L}}$ is lake evaporation. Rearranging, the proportional surface area of the lake relative to the basin area (Hudson and Quade, 2013) is: 


$$
\frac{A_{L}}{A_{B}}(\%)=\frac{P_{\text {run }}}{E_{L}-P+P k_{\text {run }}} \times 100
$$

We relate EL to net radiation $(\mathrm{RN})$ and temperature using the Priestley-Taylor equation (see the Data Repository). To directly quantify the precipitation-runoff relationship under different climatic conditions, we impose a Budyko curve (cf. Broecker, 2010; Greve et al., 2015). We determine $\mathrm{k}_{\text {run }}$ as:

$$
1-\mathrm{k}_{\mathrm{run}}=\frac{\mathrm{ET}}{\mathrm{P}}=1+\frac{\mathrm{E}_{\mathrm{p}}}{\mathrm{P}}-\left(1+\left(\frac{\mathrm{E}_{\mathrm{p}}}{\mathrm{P}}\right)^{\omega}\right)^{1 / \omega}
$$

where $E_{p}$ is potential evapotranspiration, ET is evapotranspiration, and $\omega$ is a free parameter that integrates the hydroclimatic properties of a watershed (Roderick et al., 2014; Greve et al., 2015). This framework ensures that lake water balance calculations are constrained to realistic bounds, and imposes a nonlinear response of runoff to changes in precipitation. Previous modeling for terminally draining basins in the GB (Matsubara and Howard, 2009; Barth et al., 2016) shows that, for determining firstorder trends in terminally draining basins, more complex hydrologic simulations follow the precipitation-runoff relationship imposed by the Budyko framework.

We populate the parameters $\mathrm{P}$ and $\mathrm{E}_{\mathrm{p}}$, and assume $\omega$ values (see below), in Equation 3 to solve for krun, and populate P, EL and krun in Equation 2 to solve for $A_{L} / A_{B}$. We use the energy, evapotranspiration, and precipitation fields from the North American Regional Reanalysis (NARR, https://www.esrl.noaa.gov/psd/data/gridded/data.narr.html) for the modern sensitivity analysis, the Paleoclimate Modelling Intercomparison Project 3 (PMIP3, https://pmip3.1sce.ipsl.fr/; Braconnot et al., 2012) ensemble for the LGM (ca. $21 \mathrm{ka}$ ), and the Pliocene Model Intercomparison Project (PlioMIP, https://geology .er.usgs.gov/egpsc/prism/prism_1_23/prism_pliomip.html; Haywood et al., 2013) 
ensemble for the mid-Pliocene (defined as 2.9-3.3 Ma). This analysis is implemented over model land grid cells across the western USA $\left(30^{\circ}-45^{\circ} \mathrm{N}, 102^{\circ}-121^{\circ} \mathrm{W}\right)$. For a subset of the analysis, we use a smaller region representing the southern GB $\left(34^{\circ}-39^{\circ} \mathrm{N}\right.$, $\left.114^{\circ}-119^{\circ} \mathrm{W}\right)$. Potential evapotranspiration $\left(\mathrm{E}_{\mathrm{p}}\right)$ is approximated as the liquid water equivalent of the net downward radiation at the surface $\left(\mathrm{R}_{\mathrm{N}}\right)$, which is balanced by the sensible $(\mathrm{H})$ and latent $(\mathrm{LE})$ heat fluxes:

$$
E_{p}=\frac{R_{N}}{L}=\frac{R_{S, i}-R_{S, o}+R_{L, i}-R_{L, 0}}{L}=\frac{L E+H}{L},
$$

where $\mathrm{L}$ is the latent heat of evaporation, and radiation (R) subscripts denote incoming (i) and outgoing (o), and long-wave (L) and short-wave (S), radiation (Roderick et al., 2014). These variables are taken as average annual sums from climate model simulations and NARR data for the domains in Figure 1.

We also forward model lake areas using climate model output. Using the climate model- derived $\mathrm{E}_{\mathrm{p}}$ and $\mathrm{P}$ values, along with domainwide $\omega$ values derived from the climate model's individual output (see the Data Repository), we calculate the runoff coefficient $\left(k_{\text {run }}\right)$ and forward model normalized lake areas $\left(A_{L} / A_{B}\right)$.

To analyze the sensitivity of the regional water balance, we use the distribution of the variables in Equations 2 and 4 from NARR (see the Data Repository). Using changes in temperature of $-15 \mathrm{~K}$ to $+10 \mathrm{~K}$ relative to modern, we scale potential evapotranspiration $\left(\mathrm{E}_{\mathrm{p}}=\mathrm{R}_{\mathrm{N}} / \mathrm{L}\right)$ by $1.6 \% / \mathrm{K}$ and lake evaporation $\left(\mathrm{E}_{\mathrm{L}}\right)$ using the PriestleyTaylor equation (see the Data Repository). We scale precipitation from $0.2 \times$ to $3.25 \times$ of modern. For the sensitivity analysis, $\omega=2.6$, following Greve et al. (2015) (see the Data Repository for further discussion). These ranges encapsulate proxy-derived precipitation and temperature estimates for the mid-Pliocene and LGM intervals (Dowsett et al., 1994; 
Molnar and Cane, 2007; Matsubara and Howard, 2009). This normalization is consistent with other approaches that assess hydroclimate change relative to modern observations (e.g., Ibarra et al., 2014; Barth et al., 2016).

\subsection{Proxy Comparisons}

The spatial distributions of lakes and moisture proxies during the LGM and midPliocene (Fig. 1) were similar despite different climate states. During the LGM, most terminally draining basins in the western USA contained lakes covering $\sim 9.2 \%(4.6 \%-$ $19.2 \%$, median and interquartile range [IQR]) of their basin areas, with the largest basin area-normalized lake areas located in the northern GB (up to 49.0\%). During the midPliocene, early Piacenzian lake sediment areas compiled by Pound et al. (2014) are proportionally smaller, and primarily located in the modern-day southwest GB and Mojave Desert region (Fig. 1B). These lakes cover $\sim 4.8 \%(1.2 \%-6.5 \%)$ of their basin areas, though we note large potential uncertainties in determining basin areas. Extant (playa) lakes in the dry western GB (Table DR2) cover 1.0\% (0.3\%-3.2\%) of modern terminally draining basins.

Macrostrat suggests that Pliocene lakes existed elsewhere in the western USA, likely within modern terminally draining basins (see the Data Repository). Proxy evidence from vegetation, glaciers, speleothems, and soils for the LGM suggests mostly drier-than-modern conditions approaching the ice sheet to the north, with some dry conditions east and northeast of the GB (Oster et al., 2015). Conversely, mid-Pliocene wet conditions appear to have extended farther east than in the LGM (Fig. 1), consistent with proposed "El Niño-like" climatological conditions involving a south-shifted Pacific 
storm track and increased precipitation (Molnar and Cane 2007; Winnick et al. 2013). Interpretation of wetter or drier conditions from vegetation records is complicated by the effect of changing atmospheric $p \mathrm{CO}_{2}$ (Prentice et al., 2011; Scheff et al., 2017). Pollen records that indicate drier conditions during the LGM (wetter in the Pliocene) may, in part, be responding to lower (higher) atmospheric $p \mathrm{CO}_{2}$ ( 180 versus $\left.400 \mathrm{ppm}\right)$.

Regardless, the distribution of wetter and drier pollen records supports the inferred spatial changes in hydroclimate from terminally draining lakes in the LGM and mid-Pliocene.

\subsection{Hydrologic Modeling}

To better understand the role of temperature and precipitation in driving patterns of lake size distributions, we analyze how lake area cumulative distribution functions (CDFs) respond to changes in temperature (via EL, Ep , and krun) and precipitation (Fig. 2A). We vary temperature and precipitation, and assume the modern median Budyko scaling parameter $(\omega=2.6$; Greve et al., 2015). Precipitation changes result in an increasing or decreasing proportion of larger basin area- normalized lake areas with increasing or decreasing precipitation. Changes due to temperature are smaller in magnitude than those of precipitation, with decreasing or increasing temperatures causing increasing or decreasing occurrence of large basin area-normalized lake areas. In Figure $2 \mathrm{C}$, we contour median $(\mathrm{CDF}=0.5)$ normalized lake area to changes in precipitation and temperature. Assuming temperature estimates from other proxies for the western USA (Matsubara and Howard, 2009), we find that a majority of LGM lake levels are explained by moderate to large increases in precipitation (shaded blue IQR with precipitation factors of $\sim 0.75-1.5$ of modern; Matsubara and Howard, 2009; Ibarra et al., 
2014) accompanied by small decreases in evaporation. Further, decreased evaporative demand due to decreased temperature is of moderate importance for LGM lake areas when the distribution is adjusted to account for the observation that LGM stillstands were lower than the observed maximum highstands in the northern GB (Fig. DR3 in the Data Repository). In contrast, increased mid-Pliocene temperatures (Dowsett et al., 1994; Molnar and Cane, 2007) and the attendant increase in evaporative demand necessitate precipitation increases (Fig. 2C) to explain the distribution of lake areas, particularly when the southern GB is analyzed independently (shaded orange with IQR precipitation factor $>1$; Fig. 2D). Further, because the mid-Pliocene data have been derived primarily from basinal sedimentary deposits, which may have experienced subsequent erosion or burial, our distribution of mid-Pliocene areas may be an underestimate in precipitation increases.

Climate models and our proxy compilations demonstrate that LGM and midPliocene precipitation and temperature changed in spatially heterogeneous ways, even in the sign of precipitation (cf. Molnar and Cane, 2007; Oster et al., 2015). For example, during the LGM, western USA precipitation exhibited a pronounced southwest-northeast dipole (Oster et al., 2015; Lora et al., 2017). When terminally draining basins in the southern portion of the GB are analyzed independently, large increases in precipitation $(1.3 \times$ to $1.6 \times)$ are required to drive LGM lake levels because temperature decreased less than further-inland terminally draining basins (Fig. 2D). Further, within the southern GB domain, the distribution of midPliocene lakes (Fig. 1B) requires large precipitation increases $(1.6 \times$ to $2.0 \times)$ (Fig. 2D). 
Our sensitivity analyses do not account for spatially variable anomalies. Therefore, we carry out similar calculations using climate model output (Fig. 2B). There is significant spread in the forward-modeled lake area anomalies. Notably, some LGM models have CDFs similar to the ensemble average CDF for the mid-Pliocene, and a comparison of these results to the distribution of lake areas in Figure 2B shows agreement between the range of observations and the climate model output for both periods. However, because the region of interest is averaged over both terminally draining and open basins, and as the PMIP3 and PlioMIP climate model simulations do not yet parameterize permanent lakes in their boundary conditions (cf. Pound et al., 2014), the climate model distributions in Figure 2B show more heavily tailed distributions than the range of observations.

\subsection{Implications}

Hydroclimate in the western USA responded nonlinearly to past climatic forcings. Increased precipitation with reduced evaporative demand resulted in wetter conditions during colder-thanpreindustrial periods. Further, increased moisture convergence may have been a mechanism for wetter conditions during warmer-than-preindustrial periods. Consequently, the interglacial western USA appears to represent a local aridity maximum that is transitional between two different wet states, resulting in the fewest and smallest lakes compared to geologically recent colder and warmer periods. Thus, past climatic change did not result in unidirectional changes in the regional water balance; rather, the interplay between thermodynamic and dynamic effects results in a more complex, nonlinear response. The mechanism of increased moisture convergence during the mid- 
Pliocene is beyond the scope of this study. However, the existence of background El Niño-like conditions, driven by reduced meridional and zonal sea-surface temperature gradients (Burls and Fedorov, 2017), may have strengthened southwesterly moisture delivery (Molnar and Cane, 2007; Winnick et al., 2013; Haywood et al., 2013), resulting in greater wintertime precipitation that fed the southwest USA lakes. While the direct applicability of mid-Pliocene conditions to future warming scenarios remains unclear (Burls and Fedorov, 2017), our results suggest that if future warming results in similar El Niño-like tropical Pacific conditions, aridity may decrease in the western USA.

Our analysis demonstrates how differences in regional atmospheric moisture divergence and convergence, along with regional water and energy balances (e.g., Seager et al., 2014; Putnam and Broecker, 2017), are recorded by lake deposits. Future work to better constrain lake and terminally draining basin areas for underconstrained geologic time slices will provide new constraints on the terrestrial hydroclimate response to climatic change

\subsection{Acknowledgements}

We thank Alan Carroll and three anonymous reviewers for thorough reviews. We thank P.J. Dennedy-Frank, K. Maher, T.J. Kukla, and A.J. Ritch. We acknowledge the climate modeling groups for making output available, and the Program for Climate Model Diagnosis and Intercomparison (PCMDI) and A. Haywood for output distribution. This work was supported by National Science Foundation grant EAR-1450357 to Chamberlain. 


\subsection{References}

Barth, C., Boyle, D.P., Hatchett, B.J., Bassett, S.D., Garner, C.B., and Adams, K.D., 2016, Late Pleistocene climate inferences from a water balance model of Jakes Valley, Nevada (USA): Journal of Paleolimnology, v. 56, p. 109-122, https://doi.org/10.1007/s10933-016-9897-z.

Benson, L.V., Currey, D.R., Dorn, R.I., Lajoie, K.R., Oviatt, C.G., Robinson, S.W., Smith, G.I., and Stine, S., 1990, Chronology of expansion and contraction of four great Basin lake systems during the past 35,000 years: Palaeogeography, Palaeoclimatology, Palaeoecology, v. 78, p. 241-286, https://doi.org/10.1016/0031-0182(90)90217-U.

Braconnot, P., Harrison, S.P., Kageyama, M., Bartlein, P.J., Masson-Delmotte, V., AbeOuchi, A., Otto-Bliesner, B., and Zhao, Y., 2012, Evaluation of climate models using palaeoclimatic data: Nature Climate Change, v. 2, p. 417-424, https://doi.org/10.1038/nclimate1456.

Broecker, W., 2010, Long-term water prospects in the Western United States: Journal of Climate, v. 23, p. 6669-6683, https://doi.org/10.1175/2010JCLI3780.1.

Burls, N.J., and Fedorov, A.V., 2017, Wetter subtropics in a warmer world: Contrasting past and future hydrological cycles: Proceedings of the National Academy of Sciences of the United States of America, v. 114, p. 12888-12893, https://doi.org/10.1073/pnas.1703421114.

Carroll, A.R., and Bohacs, K.M., 1999, Stratigraphic classification of ancient lakes: Balancing tectonic and climatic controls: Geology, v. 27, p. 99-102, https://doi.org/10.1130/0091-7613(1999)027<0099:SCOALB>2.3.CO;2. 
Dowsett, H., Thompson, R., Barron, J., Cronin, T., Fleming, F., Ishman, S., Poore, R., Willard, D., and Holtz, T., Jr., 1994, Joint investigations of the Middle Pliocene climate I: PRISM paleoenvironmental reconstructions: Global and Planetary Change, v. 9, p. 169-195, https://doi.org/10.1016/0921-8181(94)90015-9.

Greve, P., Gudmundsson, L., Orlowsky, B., and Seneviratne, S.I., 2015, Introducing a probabilistic Budyko framework: Geophysical Research Letters, v. 42, p. 22612269, https://doi.org/10.1002/2015GL063449.

Haywood, A.M., et al., 2013, Large-scale features of Pliocene climate: results from the Pliocene Model Intercomparison Project: Climate of the Past, v. 9, p. 191-209, https://doi.org/10.5194/cp-9-191-2013.

Hudson, A.M., and Quade, J., 2013, Long-term east-west asymmetry in monsoon rainfall on the Tibetan Plateau: Geology, v. 41, p. 351-354, https://doi.org/10.1130/G33837.1.

Ibarra, D.E., Egger, A.E., Weaver, K.L., Harris, C.R., and Maher, K., 2014, Rise and fall of late Pleistocene pluvial lakes in response to reduced evaporation and precipitation: Evidence from Lake Surprise, California: Geological Society of America Bulletin, v. 126, p. 1387-1415, https://doi.org/10.1130/B31014.1.

Lora, J.M., Mitchell, J.L., Risi, C., and Tripati, A.E., 2017, North Pacific atmospheric rivers and their influence on western North America at the Last Glacial Maximum: Geophysical Research Letters, v. 44, p. 1051-1059, https://doi.org/10.1002/2016GL071541.

Matsubara, Y., and Howard, A.D., 2009, A spatially explicit model of runoff, evaporation, and lake extent: Application to modern and late Pleistocene lakes in 
the Great Basin region, western United States: Water Resources Research, v. 45, W06425, https://doi.org/10.1029/2007WR005953.

Mifflin, M.D., and Wheat, M.M., 1979, Pluvial Lakes and Estimated Pluvial Climates of Nevada: Carson City, Nevada, Nevada Bureau of Mines and Geology Bulletin, v. $95,57 \mathrm{p}$.

Molnar, P., and Cane, M.A., 2007, Early Pliocene (pre-Ice Age) El Niño-like global climate: Which El Niño?: Geosphere, v. 3, p. 337-365, https://doi.org/10.1130/GES00103.1.

Oster, J.L., Ibarra, D.E., Winnick, M.J., and Maher, K., 2015, Steering of westerly storms over western North America at the Last Glacial Maximum: Nature Geoscience, v. 8, p. 201-205, https://doi.org/10.1038/ngeo2365.

Pound, M.J., Tindall, J., Pickering, S.J., Haywood, A.M., Dowsett, H.J., and Salzmann, U., 2014, Late Pliocene lakes and soils: A global data set for the analysis of climate feedbacks in a warmer world: Climate of the Past, v. 10, p. 167-180, https://doi.org/10.5194/cp-10-167-2014.

Prentice, I.C., Harrison, S.P., and Bartlein, P.J., 2011, Global vegetation and terrestrial carbon cycle changes after the last ice age: The New Phytologist, v. 189, p. 988998, https://doi.org/10.1111/j.1469-8137.2010.03620.x.

Putnam, A.E., and Broecker, W.S., 2017, Human-induced changes in the distribution of rainfall: Science Advances, v. 3, p. e1600871, https://doi.org/10.1126/sciadv.1600871.

Reheis, M.C., Adams, K.D., Oviatt, C.G., and Bacon, S.N., 2014, Pluvial lakes in the Great Basin of the western United States-A view from the outcrop: Quaternary 
Science Reviews, v. 97, p. 33-57, https://doi.org/10.1016/j.quascirev.2014.04.012.

Roderick, M.L., Sun, F., Lim, W.H., and Farquhar, G.D., 2014, A general framework for understanding the response of the water cycle to global warming over land and ocean: Hydrology and Earth System Sciences, v. 18, p. 1575-1589, https://doi.org/10.5194/hess-18-1575-2014.

Scheff, J., Seager, R., Liu, H.B., and Coats, S., 2017, Are glacials dry? Consequences for paleoclimatology and for greenhouse warming: Journal of Climate, v. 30, p. 6593-6609, https://doi.org/10.1175/JCLI-D-16-0854.1.

Seager, R., Neelin, D., Simpson, I., Liu, H., Henderson, N., Shaw, T., Kushnir, Y., Ting, M., and Cook, B., 2014, Dynamical and thermodynamical causes of large-scale changes in the hydrological cycle over North America in response to global warming: Journal of Climate, v. 27, p. 7921-7948, https://doi.org/10.1175/JCLID-14-00153.1.

Winnick, M.J., Welker, J.M., and Chamberlain, C.P., 2013, Stable isotopic evidence of El Niño-like atmospheric circulation in the Pliocene western United States: Climate of the Past, v. 9, p. 903-912, https://doi.org/10.5194/cp-9-903-2013. 


\subsection{Figures}

Figure 1. Maps of lakes and hydroclimate-sensitive proxies, western United States. A:

Last Glacial Maximum (LGM) lake extents. B: Mid-Pliocene lake locations, from Pound et al. (2014) and from Macrostrat platform. Mid-Pliocene and LGM proxy networks are coded as indicating wetter, drier, or no change relative to modern. Dashed boxes denote analysis domains.

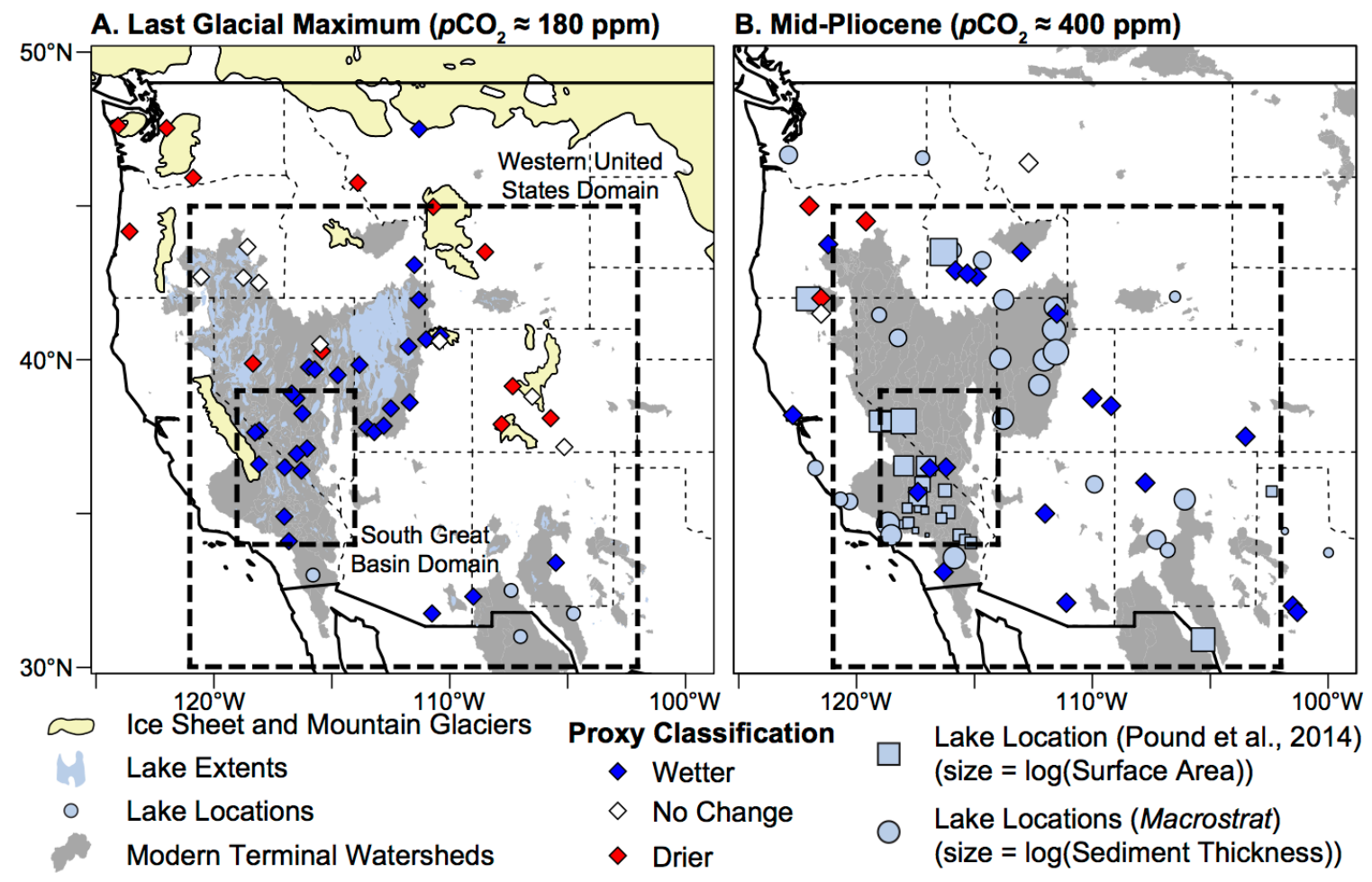


Figure 2 (next page). Climatic forcing and lake area changes, western United States. A: Scaling of modern climate distributions (cumulative distribution functions, CDFs) to linear changes in precipitation and temperature. Bold line is modern. B: Basin areanormalized lake area using climate model simulations relative to modern for western United States domain. C: Median basin area-normalized lake area (CDF $=0.5$ from panel A) contoured for changes in precipitation and temperature for the western United States. Shaded regions are interquartile range (IQR) with thick median lines of observed lake areas and range of temperature change estimates relative to modern. D: Same as C, for southern Great basin domain. LGM-Last Glacial Maximum; $A_{L}$ - lake area; $A_{B}$ terminal basin area; max.-maximum. 


\section{B. Observations and Climate Models}

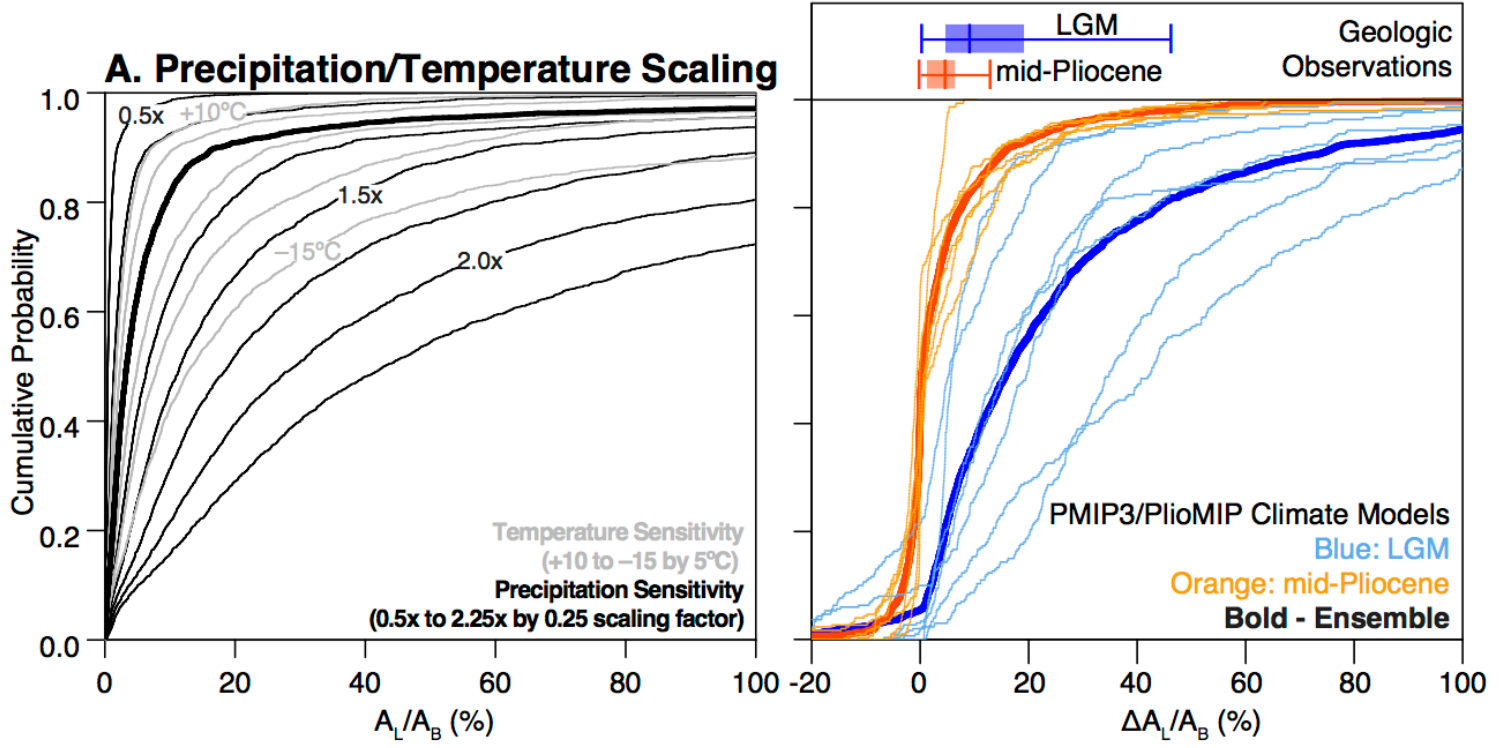

\section{Western United States Domain}

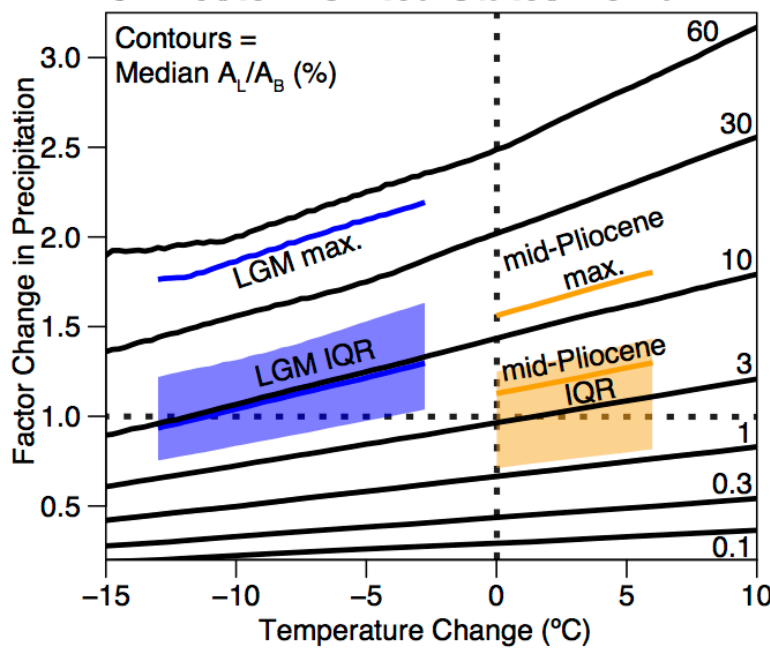

\section{South Great Basin Domain}

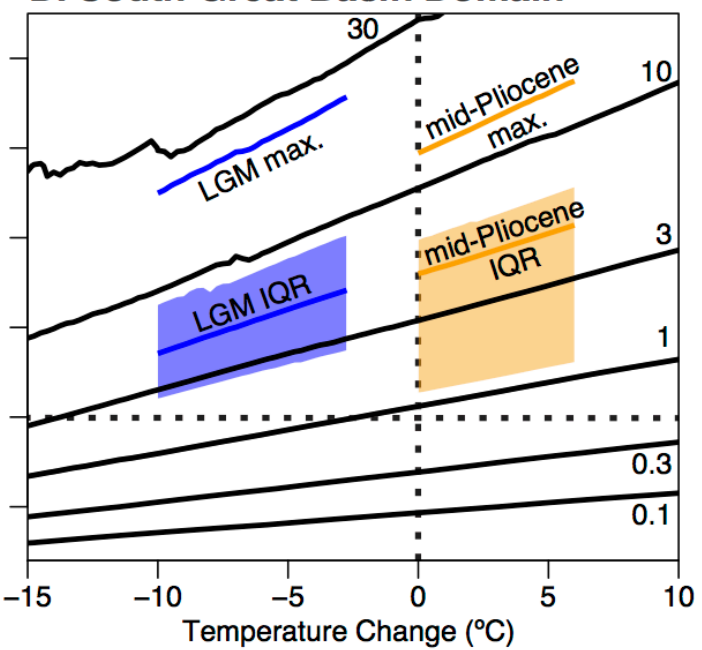




\section{CHAPTER 3}

\section{Concentration-discharge relationships of monolithologic catchments and global rivers}

\section{Chapter Introduction}

Quantifying the functional relationships between river discharge and dissolved weathering products places key constraints on our understanding of the coupling between weathering processes and climate. In this chapter I present two published mansucripts where I analyzed the concentration-discharge relationships of weathering products from geologically heterogenous global rivers as well as smaller monolithologic catchments, which serve as lithological end-members representing basalt, granite, and carbonate. Concentration-discharge relationships are modeled with power-law and solute production equations to characterize the roles of weathering efficiency and thermodynamic limits to solute concentrations in controlling integrated solute fluxes. Weathering efficiency is quantified using Damköhler coefficients and power-law exponents, which describes the resistance of solute concentrations to dilution at high runoff. We find that Damköhler coefficient values derived for basaltic catchments are a factor of 2 to 6 higher than granitic catchments, accounting for a majority of the difference in increased areanormalized fluxes from mafic (basaltic) lithologies. In doing so we show that weatherability is runoff-dependent and increases with increasing runoff. For $\mathrm{HCO}_{3}{ }^{-}$and $\mathrm{SiO}_{2}$ (aq) fluxes, for modern global runoff, the derived mean basalt/granite weatherability is $2.2(1.3-3.7,2 \sigma)$ and $1.7(1.6-2.1,2 \sigma)$, respectively. Using a mix-lithology dataset 
from global rivers we also demonstrate an inverse relationship between the power-law exponent and the Damköhler coefficient, which both increase and asymptote as catchments exhibit increasing chemostatic behavior. These two studies, focusing on monolithologic catchments (3.1; Ibarra et al., 2016, Geochemica et Cosmochemica Acta) and global rivers (3.2; Ibarra et al., 2017, Acta Geochemica) demonstrate the utility of long term monitoring networks providing discharge-resolved concentration datasets to quantify global weathering fluxes and the processes that control them. 


\subsection{Differential weathering of basaltic and granitic catchments from concentration-discharge relationships}

Daniel E. Ibarra ${ }^{\mathrm{a}}$, Jeremy K. Caves ${ }^{\mathrm{a}}$, Seulgi Moon ${ }^{\mathrm{b}}$, Dana L. Thomas ${ }^{\mathrm{c}}$, Jens Hartmann ${ }^{\mathrm{d}}$, C. Page Chamberlain ${ }^{\mathrm{a}}$, and Kate Maher ${ }^{\mathrm{c}}$

${ }^{a}$ Department of Earth System Science, Stanford University, 473 Via Ortega, Rm. 140, Stanford, CA 94305-4216, USA

${ }^{\mathrm{b}}$ Department of Earth, Planetary, and Space Sciences, University of California, Los Angeles, 595 Charles Young Dr. East, Los Angeles, CA 90095, USA

${ }^{\mathrm{c}}$ Department of Geological Sciences, Stanford University, 450 Serra Mall, Building 320, Stanford, CA 94305-2115, USA

${ }^{\mathrm{d}}$ Institute for Geology, Center for Earth System Research and Sustainability, Universität Hamburg, Geomatikum, 20146 Hamburg, Germany

Reproduced with permission from Ibarra, D.E., Caves, J.K., Moon, S., Thomas, D.L., Hartmann, J., Chamberlain, C.P., Maher, K., Geochimica et Cosmochimica Acta. Copyright 2016, Elsevier

Licensed under the Creative Commons Attribution-NonCommercial 3.0 http://creativecommons.org/licenses/by-nc/3.0 


\section{Abstract}

A negative feedback between silicate weathering rates and climate is hypothesized to play a central role in moderating atmospheric $\mathrm{CO}_{2}$ concentrations on geologic timescales. However, uncertainty regarding the processes that regulate the operation of the negative feedback limits our ability to interpret past variations in the ocean-atmosphere carbon cycle. In particular, the mechanisms that determine the flux of weathered material for a given climatic state are still poorly understood. Here, we quantify the processes that determine catchment-scale solute fluxes for two lithologic end-members — basalt and granite — by applying a recently developed solute production model that links weathering fluxes to both discharge and the reactivity of the weathering material. We evaluate the model against long-term monitoring of concentrationdischarge relationships from basaltic and granitic catchments to determine the parameters associated with solute production in each catchment. Higher weathering rates in basaltic catchments relative to granitic catchments are driven by differing responses to increases in runoff, with basaltic catchments showing less dilution with increasing runoff. In addition, results from the solute production model suggest that thermodynamic constraints on weathering reactions could explain higher concentrations in basaltic catchments at lower runoff compared to granitic catchments. To understand how the response to changing discharge controls weathering fluxes under different climatic states, we define basalt/granite weatherability as the ratio of the basalt catchment flux to the granite catchment flux. This weatherability is runoff-dependent and increases with increasing runoff. For $\mathrm{HCO}_{3}{ }^{-}$and $\mathrm{SiO}_{2}$ (aq) fluxes, for modern global runoff, the derived mean basalt/granite weatherability is $2.2(1.3-3.7,2 \sigma)$ and $1.7(1.6-2.1,2 \sigma)$, respectively. 
Although we cannot determine the array of individual processes resulting in differences among catchments, the relative differences in certain model parameters that represent catchment-scale weathering fluxes of granitic and basaltic lithologies are robust. Our approach provides a mechanism that links runoff with the distribution of global sub-aerial silicate lithologies to understand how the basalt/granite weatherability of the Earth's surface may have varied on geologic timescales. The relationships between basalt/granite weatherability and runoff derived in this study could be used to parameterize the silicate weathering negative feedback to model past changes in $p \mathrm{CO}_{2}$.

Keywords: Silicate weathering; Solute fluxes; Geologic carbon cycle; Feedbacks

\subsubsection{Introduction}

Global silicate weathering rates are thought to be modulated by the geographic distribution and areal extent of rock type, growth and decay of mountain ranges, the nature of biological activity, and the intensity of the hydrologic cycle (Berner, 1991; Kump and Arthur, 1997; Gibbs et al., 1999; Hartmann et al., 2009; Pagani et al., 2009; Banwart et al., 2009; Beerling et al., 2012; Kent and Muttoni, 2013; Maher and Chamberlain, 2014; Froelich and Misra, 2014). Understanding the factors that control global silicate weathering rates is fundamental to constraining the evolution of the Earth's carbon cycle over geologic timescales (Urey, 1952; Sagan and Mullen, 1972; Walker et al., 1981; Berner et al., 1983; Volk, 1987; Berner, 1991, 2006a; Caldeira and Kasting, 1992; Caldeira, 1992, 1995; Kasting, 1993; Berner and Caldeira, 1997; Gibbs et al., 1999; Kump et al., 2000; Berner and Kothavala, 2001). 
One challenge for reconstructing past weathering rates is the considerable variability in the reactivity of the Earth's surface. For example, basaltic catchments weather faster than other silicates and account for approximately $20-35 \%$ of the modern global silicate weathering and $\mathrm{CO} 2$ consumption flux, while occupying less than $5 \%$ of sub-aerial continental area (Gíslason et al., 1996, 2009; Louvat and Allègre, 1997; Dessert et al., 2001, 2003, 2009; von Blanckenburg et al., 2004; Rad et al., 2007; Hartmann et al., 2009; Schopka et al., 2011; Gaillardet et al., 2011a; Schopka and Derry, 2012; Moon et al., 2014; Balagizi et al., 2015). The higher weathering fluxes associated with basalt weathering have been explained by the high intrinsic reactivity of basaltic mafic mineral assemblages (Oelkers and Gíslason, 2001; Dessert et al., 2003; Gíslason and Oelkers, 2003), increased porosity in the basalt weathering zone (Navarre-Sitchler et al., 2009, 2013; 2015; Sak et al., 2010, Gleeson et al., 2011), and the importance of hydrologic fluctuations that moderate the water table depth and total stream discharge (Amiotte-Suchet and Probst, 1993; Bluth and Kump, 1994; Eiriksdottir et al., 2013, 2015; Balagizi et al., 2015; Dessert et al., 2015; Liu et al., 2015). Given the importance of basaltic weathering to total global solute fluxes, recent modeling studies that reconstruct weathering fluxes over the Cenozoic suggest that the weathering of mafic terrains may have been critically important in controlling past levels of atmospheric $\mathrm{CO} 2(\mathrm{pCO} 2)(\mathrm{Li}$ and Elderfield, 2013; Kent and Muttoni, 2013; Molnar and Cronin, 2015; Jagoutz et al., 2016). However, scaling modern observations of weathering fluxes from catchments to both large spatial and temporal scales (e.g., Wallmann, 2001; Lefebvre et al., 2013; Li and Elderfield, 2013; Kent and Muttoni, 2008, 2013; Mills et al., 2014a; Li et al., 2016; Jagoutz et al., 2016; Cox et al., 2016) remains a challenge due to the lack of 
phenomenological modeling frameworks that predict weathering fluxes at both catchment and global scales under different climate states.

To reconstruct changes in the geologic past, weathering fluxes are typically parameterized using modern solute flux data to derive a "weathering rate law." These empirical laws are derived by fitting modern weathering rates to variables such as lithology, runoff, topographic slope, and temperature (Amiotte-Suchet and Probst, 1993; Bluth and Kump, 1994; White and Blum, 1995; Gaillardet et al., 1999; Dessert et al., 2001, 2003; Dupré et al., 2003; Navarre-Sitchler and Thyne, 2007; Hartmann et al., 2010, 2014a) and are often assumed to follow the form of either an exponential Arrhenius equation or power law (Velbel, 1993; White et al., 1999a; Gíslason and Oelkers, 2003; Carroll and Knauss, 2005; Gíslason et al., 2009; Eiriksdottir et al., 2013; Li and Long, 2014; Moon et al., 2014; Torres et al., 2015; Li et al., 2016). However, as discharge increases, solute concentrations decrease due to dilution, which results in an apparent plateau in weathering fluxes even as runoff increases (Godsey et al., 2009; Maher, 2011; Eiriksdottir et al., 2013; Maher and Chamberlain, 2014). Close examination of the catchment-scale weathering data on which these empirical weathering laws are derived (e.g., Bluth and Kump, 1994; Godsey et al., 2009; Gíslason et al., 2009; Clow and Mast, 2010; Maher, 2011; Eiriksdottir et al., 2013) demonstrates that the functional forms of the weathering rate laws (i.e., exponential Arrhenius or power-law) do not accurately reflect the decrease in concentration due to dilution with increasing runoff observed for individual catchments. Thus, existing frameworks do not capture the potential for weathering fluxes to plateau as runoff increases. Furthermore, if different lithologies 
exhibit variable responses to changes in runoff, global weathering fluxes may show a complex behavior depending on the time-varying areal distribution of rock types.

Maher and Chamberlain (2014) recently developed a process-based solute production framework that links weathering fluxes to both runoff and the reactivity of the weathering zone. Given that this modeling approach contains both thermodynamic and kinetic constraints, as well as physical processes that govern the travel time of water through the subsurface, the solute production model could provide a useful alternative approach for parameterizing weathering fluxes because it allows for fluxes to plateau at sufficiently high runoff. However, this model has only been evaluated against single concentration-discharge pair values (i.e., time-averaged, flux-averaged, or singlesamples) for global rivers (Maher and Chamberlain, 2014; von Blanckenburg et al., 2015) and long-term monitoring of $\mathrm{SiO}_{2}(\mathrm{aq})$ concentration-discharge patterns from a few small silicate bedrock catchments (Maher, 2011), and has not been systematically compared to rivers across gradients in lithology, climate, erosion rate, or basin size. As a consequence, it remains unclear whether such an approach could describe the variability in reactivity and hydrologic processes associated with individual catchments. Here, to isolate lithologic controls, we evaluate the ability of the solute production equations to capture patterns in concentration-discharge relationships exhibited by long-term monitoring of basaltic and granitic catchments (Fig. 1). In addition, we consider the extent to which concentration-discharge relationships can elucidate the differences in reactivity and composition that lead to large differences in area-normalized weathering fluxes between basaltic and granitic catchments. 
By comparing basaltic and granitic catchments, we quantify patterns in observed concentration-discharge relationships for the two major silicate end-member lithologies responsible for terrestrial silicate weathering (Bluth and Kump, 1994; White and Blum, 1995; Kump and Arthur, 1997; Kump et al., 2000; Dessert et al., 2001; Berner, 2006b, 2008). We focus our analysis on two important parameters: (1) the degree to which solute fluxes from individual catchments resist dilution at high runoff and (2) the maximum solute concentrations. These two parameters determine the efficiency with which a catchment produces solute. We find that weathering fluxes from basaltic catchments are both more resistant to dilution at high runoff and have a greater maximum solute concentration, implying that basaltic catchments are more efficient at producing solute for a given climate. We further use these two parameters to show how the basalt catchment flux normalized to the granite catchment flux - the basalt/granite weatherability ratio — changes with runoff.

Earth surface weatherability is often treated as a tunable parameter in biogeochemical models (e.g., Kump and Arthur, 1997; Gibbs et al., 1999; Berner, 2006a, 2008; Mills et al., 2014a) because it determines the degree of coupling between climate and weathering. In turn, this coupling is a measure of the strength of the negative feedback between climate/atmospheric $p \mathrm{CO}_{2}$ and silicate weathering. A weak coupling implies that weathering fluxes change little in response to changes in climate, whereas a strong coupling suggests that weathering responds rapidly to small changes in climate (West, 2012; Maher and Chamberlain, 2014; Goll et al., 2014; Caves et al., 2016). Our work demonstrates that weatherability cannot necessarily be treated as a constant, even over the short timescales that characterize rapid climate change in the geologic record. 
Using these results, we propose a framework for linking basalt/granite weatherability to understand the behavior of the silicate weathering feedback over Earth history.

\subsubsection{Background}

Quantifying differences in concentration-discharge relationships among catchments of different lithologies may improve models for how weathering fluxes respond to changes at the Earth surface. We use a modeling framework outlined below that starts with the Damköhler number $(D a)$, a dimensionless number that is the ratio of the fluid travel time $\left(T_{f}[\mathrm{yr}]\right)$ to the time required to reach equilibrium $\left(T_{e q}[\mathrm{yr}]\right)$ (Johnson and DePaolo, 1994; Steefel and Maher, 2009; Maher, 2010; Maher and Chamberlain, 2014; Li et al., 2014):

$$
D a=\frac{T_{f}}{T_{e q}}=\frac{R_{n} L \phi}{q C_{\max }}
$$

where $q[\mathrm{~m} / \mathrm{yr}]$ is the flow rate (specific discharge), $C_{\max }[\mu \mathrm{mol} / \mathrm{L}]$ is the maximum solute concentration, $R_{n}[\mu \mathrm{mol} / \mathrm{L} / \mathrm{yr}]$ is the net mineral dissolution rate, and $L[\mathrm{~m}]$ is the flowpath length, which is multiplied by $\phi$ (the effective porosity) to give the reactive flowpath length $L \phi$. A large Damköhler number $(D a>1)$ implies that reaction rates outpace advection such that local equilibrium within the weathering zone controls the solute concentrations (Sverdrup and Warfvinge, 1988; Steefel and Maher, 2009; Maher, 2010, 2011; Siirila and Maxwell, 2012; Maher and Chamberlain, 2014; Maher and Druhan, 2014; Li et al., 2014). Although the $D a$ approach is widely used in reactive transport because it incorporates the balance between physical and chemical processes, the Damköhler number is non-unique when attempting to understand the importance of climatic versus lithologic controls on weathering, because changes in $D a$ can be driven 
by changes in travel time $\left(T_{f}\right)$ or equilibrium time $\left(T_{e q}\right)$, where the latter is set by the ratio between maximum solute concentrations and net dissolution rates $\left(T_{e q}=C_{\max } / R_{n}\right)$. For example, two catchments may have the same $D a$, but very different $T_{f}$ or $T_{e q}$, meaning their response to changes in runoff (i.e., flow rate) will be very different (Fig. 2a). Thus, runoff can be factored out of $D a$ to derive the Damköhler coefficient $(D w[\mathrm{~m} / \mathrm{yr}]=D a \times$ $\left.q=L \phi / T_{e q}\right)$, which describes the reactivity of the material in the weathering zone over a given length scale, and modifies the relationship between concentration and discharge. The implication for concentration-discharge relationships is that $D w$ values describe the relative rate of increase in solute concentration for a given flowpath length. Thus, increased $D w$ values can result from either higher reaction rates or long flow paths (Maher and Chamberlain, 2014). Systems with high $D w$ values exhibit less dilution with increasing runoff compared to catchments with lower $D w$ values (Fig. 2a).

In this study, we focus on lithologic controls on $D w$. We do not specifically evaluate the effect of erosion rates or differences in climate on $D w$, although we do evaluate for relationships between $D w$ and temperature. Previous work with this solute production model has demonstrated that rapidly eroding mountain belts tend to have higher $D w$ values (Maher and Chamberlain, 2014). Accordingly, we expect the intralithology $D w$ distributions to be partially driven by these other factors. Given that the Dw value of a catchment reflects the ratio of the reactive flowpath length $(\mathrm{L} \phi)$ to the equilibrium time (Teq), both of which may be impacted by erosion or climate, we thus emphasize how further stream measurements and upslope analyses might aid in deconvolving the derived concentration-discharge parameters presented below. 


\section{Solute production framework}

Data from individual catchments display a range of solute concentrations $(C$ $[\mu \mathrm{mol} / \mathrm{L}])$ as a function of discharge $\left(Q\left[\mathrm{~m}^{3} / \mathrm{yr}\right]\right)($ i.e. $C-Q$ relationships $)$. The patterns in $C-Q$ relationships that emerge in response to fluctuations in discharge are thought to indicate the processes that control the weathering flux. Thus, such patterns may inform the response of weathering rates to changes in the local climate (Godsey et al., 2009). Here, specific discharge or runoff $(q[\mathrm{~m} / \mathrm{yr}])$ is defined as the instantaneous discharge $(Q$ $\left.\left[\mathrm{m}^{3} / \mathrm{yr}\right]\right)$ divided by the catchment area $(A[\mathrm{~m} 2])$, and $C[\mu \mathrm{mol} / \mathrm{L}]$ is the solute concentration (Fig. 1b). Below and for the remainder of the paper, we primarily discuss concentration-runoff $(C-q)$ relationships because area normalization allows for direct comparison between catchments whose areal extents may differ by many orders of magnitude.

Maher and Chamberlain (2014) derived a framework for relating solute $(C$ $[\mu \mathrm{mol} / \mathrm{L}])$ production to runoff $(q[\mathrm{~m} / \mathrm{yr}])$ :

$$
C=\frac{C_{0}}{1+D w / q}+C_{\max } \frac{D w / q}{1+D w / q}
$$

where $D w[\mathrm{~m} / \mathrm{yr}]$ is the Damköhler coefficient, $C_{0}$ is the initial solute concentration, and $C_{\max }$ is the maximum solute concentration, which may be associated with a "thermodynamic limit" imposed by approach to equilibrium with the primary and/or secondary mineral assemblages. Previous work with this solute production model (Maher and Chamberlain, 2014; von Blanckenburg et al., 2015) included a scaling factor (7.39) multiplied by the $D w$ coefficient that emerged from comparison between 1-dimensional reactive transport simulations and the analytical solution above (cf. Maher and Chamberlain, 2014). In the current work, we exclude the scaling factor from the analysis 
since we make no comparison to reactive transport simulations and account for the scaling factor when comparing to previous results from von Blanckenburg et al. (2015) and Maher and Chamberlain (2014). Here, $C_{0}$ is the initial solute concentration, derived from atmospheric deposition and/or hydrothermal or deep groundwater inputs that mix with water in the weathering zone or the river and are independent of discharge. For most catchments, Eq. (2) can be simplified if $C_{0}$ is assumed to be zero (Maher and Chamberlain, 2014):

$$
C=C_{\max } \frac{D w / q}{1+D w / q}
$$

Observations of constant concentrations with increasing discharge (i.e., "chemostatic" behavior) have demonstrated that $C_{\max }$ can vary among catchments (Godsey et al., 2009; Maher, 2011). The purpose of the $C-q$ analysis carried out in this study is to derive $C_{\max }$ and $D w$ values for individual basaltic and granitic catchments, and determine trends between these two sample groups. $D w$ values derived from concentration-runoff data between catchments of comparable lithology allow for a direct, area-independent comparison of the efficiency of solute generation. At a given runoff, catchments with larger $D w$ values are more efficient at generating solute and hence more likely to approach the $C_{\max }$ concentration. For example, Fig. 2a demonstrates schematically how, for a given $C_{\max }$, a higher $D w$ results in a higher $\mathrm{SiO}_{2}(\mathrm{aq})$ concentration at a given runoff (yellow point $(D w=0.15)$ vs. green point $(D w=1.5))$. Here, we use $\mathrm{SiO}_{2}(\mathrm{aq})$ to demonstrate these key concepts because it is a neutral species and closely tracks primary mineral silicate weathering (e.g., feldspar to a secondary clay mineral $)$ although we do consider and analyze other major ions $\left(\mathrm{HCO}_{3}{ }^{-}, \mathrm{Ca}^{2+}, \mathrm{Mg}^{2+}\right.$ and $\mathrm{Na}^{+}$) and measurements of chemical weathering in this paper. 
The runoff value where dilution effects are observed varies by element (e.g., $\mathrm{SiO}_{2}$ (aq) dilution occurs at runoff values higher than for $\mathrm{HCO}_{3}^{-}$; Kump et al., 2000; Godsey et al., 2009; Moon et al., 2014). Dilution curves have been previously derived empirically assuming a power law relationship $\left(C=a Q^{b}\right.$, where $a$ and $b$ are constants; Pokrovsky et al., 2005; Godsey et al., 2009; Moon et al., 2014). Chemostatic behavior has been traditionally defined as occurring when the power law exponent $(b)$ approaches zero (e.g., Godsey et al., 2009; Moon et al., 2014; Torres et al., 2015). Previous work has demonstrated the importance of quantifying and understanding the mechanisms behind chemostatic concentrations of different elements observed in rivers for different lithologies and, most importantly, the extent to which maximum concentrations are associated with a thermodynamic limitation (White et al., 1996; Clow and Mast, 2010; Maher, 2011; Maher and Chamberlain, 2014; Maher and Druhan, 2014).

Finally, the equations presented above assume an idealized exponential transit time distribution of discharge, and thus concentrations represent the flux-weighted average concentration recorded by streams (cf. Małoszewski and Zuber, 1982; McGuire et al., 2005; McGuire and McDonnell, 2006; Steefel and Maher, 2009; Maher, 2011; Zapata-Rios et al., 2015), although observations and modeling of transit time distributions are complex and demonstrate fractal behavior (cf. Kirchner et al., 2000; Scher et al., 2002; Kollet and Maxwell, 2008; Kirchner and Neal, 2013; Maxwell et al., 2016). In our analysis we derive $D w$ values, which represent the balance of mean transit time to mean reaction rate to take into account permeability and flowpath heterogeneity (Maher, 2011; Maher and Druhan, 2014; Maher and Chamberlain, 2014; Li et al., 2014; Torres et al., 2015). 


\section{Catchment weathering potential}

From Eq. (3), the area normalized weathering flux ( $W[\mathrm{t} / \mathrm{km} 2 / \mathrm{yr}])$ is obtained by multiplying the concentration $(C)$ by the $\operatorname{runoff}(q)$ :

$$
W=q C_{\max } \frac{D w / q}{1+D w / q}
$$

and converting to mass using the appropriate atomic or molecular weight $(\mathrm{g} / \mathrm{mol})$ of the solute of interest. At higher runoff, solute fluxes from a given catchment or river basin plateau due to increased dilution, defining a maximum weathering flux (Wmax in Fig. 2b). Higher $D w$ and $C_{\max }$ values result in a higher $W_{\max }$ value (the value as $q$ approaches infinity; i.e., $\left.W_{\max }=D w \times C_{\max }\right)$. For a given mean observed solute flux $\left(W_{o b s}\right)$, we can calculate the possible maximum increase in the weathering flux and the absolute weathering potential $(\triangle W P[\mathrm{t} / \mathrm{km} 2 / \mathrm{yr}])$ of a catchment, which is the difference between the $W_{\max }$ and the $W_{o b s}$ :

$$
\Delta W P=W_{\max }-W_{o b s}
$$

To compare between catchments of different Dw values, this maximum weathering flux is expressed as the normalized weathering potential $\left(W P_{\text {norm }}[\%]\right)$ :

$$
W P_{\text {norm }}=\left(\frac{\Delta W P}{W_{\max }}\right) \cdot 100
$$

As shown schematically in Fig. $2 \mathrm{~b}$, for a given $D w$ and $C_{\max }$, the weathering potential for a chemostatic catchment (blue point) is higher than for a catchment located on the dilution curve (green and red points). Additionally, for a given runoff and $C_{\max }$, catchments with a higher $D w$ have a higher weathering potential (green point where $D w=$ $1.5 \mathrm{~m} / \mathrm{yr}$ and $W P_{\text {norm }}=93.3 \%$ ) than catchments with a lower Dw (yellow point where Dw 
$=0.15 \mathrm{~m} / \mathrm{yr}$ and $W P_{\text {norm }}=59.6 \%$ ). The utility of this new metric is that it incorporates both Dw and Cmax. Thus, we account for lithology-dependent variations and distributions in $C_{\max }$ values (e.g., Dessert et al., 2003; Dupré et al., 2003) when evaluating catchment weathering efficiency.

For catchments where $C_{0}$ is non-zero due to contributions from atmospheric deposition (e.g., soluble dust deposition or sea spray) or hydrothermal or deep groundwater inputs, Eq. (2) should be used to determine the catchment Dw. However, to represent only the silicate-weathering contribution to the solute flux, $C_{0}$ is subtracted from the dataset. Fig. 3 demonstrates how, within this solute production framework, there is no $W_{\max }$ when $C_{0}$ is non-zero because at high runoff the first term in Eq. (2) dominates, increasing the total solute flux proportional to increasing runoff. Therefore to calculate $D_{w}$ and $C_{\max }$ values, and the resultant $W_{\max }$ values, we correct the flux vs. runoff relationships (as shown schematically in Fig. 3).

\subsubsection{Methods}

\section{Data Sources}

The concentration-runoff datasets considered in this study were compiled from locations where several years ( $>2$ years) of data, comprising at least 20 solute concentration measurements, have been collected (Fig. 1a). Riverine solute data were compiled from $(1)$ small $(<10,000 \mathrm{~km} 2)$ basaltic and granitic catchments from the U.S. Geological Survey National Water Information System (USGS NWIS) and used in three previous studies (Bluth and Kump, 1994; Dessert et al., 2003; Godsey et al., 2009); (2) basaltic catchments with sufficient concentration-discharge data from Iceland 
(Eiriksdottir et al., 2013, 2015), and; (3) additional basaltic and granitic catchments ( $>90 \%$ single-lithology bedrock) identified from the Global River Chemsitry Database (GlorRiCh) using the Global Lithologic Map (GLiM) lithology maps (Hartmann and Moosdorf, 2012; Hartmann et al., 2014b). Our dataset is restricted to sites with the paired runoff and solute data needed to constrain the weathering of primary silicate minerals to secondary minerals and to quantify the resulting solutes, total dissolved solids, and cation-equivalent $\left(\mathrm{SiO}_{2}(\mathrm{aq}), \mathrm{Mg}^{2+}, \mathrm{Ca}^{2+}, \mathrm{K}^{+}, \mathrm{Na}^{+}\right.$and $\mathrm{HCO}_{3}{ }^{-}$) (e.g., Gaillardet et al., 1999; Dessert et al., 2003; Bouchez and Gaillardet, 2014). As noted by previous workers, it is difficult to fit statistically significant concentration-discharge relationships to datasets displaying minimal discharge variations (Godsey et al., 2009; Moon et al., 2014). Thus, we exclude catchment data showing minimal variations; of these, most were from catchments without sufficient temporal or seasonally representative coverage. In total, our compilation includes data from 44 basalt catchments, and 27 granite catchments (Table A1). In addition, we separate some of the basalt and granite catchments into subgroups based on region (Iceland, Hawaii, Sierra Nevada, and the Pacific Northwest; Fig. 1, Table A1).

The analysis presented here utilizes some of the longest time-series available for studying riverine dissolved loads (e.g., Godsey et al., 2009; Maher, 2011; Eiriksdottir et al., 2013, 2015; Torres et al., 2015; Moquet et al., 2015), primarily from the USGS NWIS database. We are still limited by both the lack of spatial coverage of these long timeseries datasets and by a lack of sampling at extreme runoff values (e.g., Dessert et al., 2015). However, our datasets allow to examine the influence of high runoff variabilityparticularly at extreme values and to accurately estimate $C_{\max }$ and $C_{0}$ values. To assess 
whether using individual $C-q$ pairs biases the dataset toward rare, extreme runoff values, or temporal sampling biases, we also evaluate our dataset by calculating flux-weighted average concentrations for each catchment and deriving $D w$ values from single concentration-runoff pairs (e.g., von Blanckenburg et al., 2015), assuming different Cmax values for each sample group (basalt and granite).

\section{Quantifying catchment-scale weathering efficiency from concentration-runof} relationship fitting

In order to quantify catchment-scale weathering efficiency, we first separate chemostatic and non-chemostatic catchments. For chemostatic catchments, we mathematically define with a power law b-value indistinguishable from 0 (within $95 \%, p$ $>0.05$ ) (Godsey et al., 2009). Most of these catchments still likely fit the modeling framework employed in this study, but lack a sufficient number of concentrationdischarge measurements at high runoff necessary to demonstrate dilution. For these catchments, we report $C_{\max }$ values as the median (and median absolute deviation) of all observed concentrations and do not quantify $D w$ values. For non-chemostatic catchments, we quantify catchment-specific $D w$ values using the paired concentration-runoff data and equations 1 and/or 2 . We apply a non-linear least squares fitting to derive $D w$ and $C_{\max }$ values using the Gauss-Newton algorithm ('nls2' R package, Grothendieck, 2013) similar to the Newton methods employed by Godsey et al. (2009) and Moon et al. (2014) for power law fits. Finally, we calculate these fits for a variety of dissolved species, including $\mathrm{SiO}_{2}(\mathrm{aq}), \mathrm{HCO}_{3}^{-}$(alkalinity), $\mathrm{Mg}^{2+}, \mathrm{Ca}^{2+}, \mathrm{Na}_{*}\left(\mathrm{Cl}\right.$-corrected $\mathrm{Na}^{+} ; \mathrm{Na}^{*}=\mathrm{Na}^{+}-$ 
$\mathrm{Cl}$; cf. Moon et al., 2014), for cation-equivalent $\left(2 \mathrm{Mg}^{2+}+2 \mathrm{Ca}^{2+}+\mathrm{K}^{+}+\mathrm{Na}^{+}[\mu \mathrm{eq} / \mathrm{L}]\right)$, and for total dissolved solids (TDS; $\mathrm{Mg}^{2+}+\mathrm{Ca}^{2+}+\mathrm{K}^{+}+\mathrm{Na}^{+}+\mathrm{SiO}_{2}(\mathrm{aq})[\mathrm{mg} / \mathrm{L}]$ ).

In Appendix B, we provide associated example code for fitting concentrationrunoff relationships using the Maher and Chamberlain (2014) modeling framework. The Gauss-Newton method minimizes the sum of squares of the errors between the model prediction and input dataset. The advantage of this method is that because $\mathrm{C} 0$ and $\mathrm{Cmax}$ are unknown, we can simultaneously solve for all three required parameters given sufficient sample size ( $>20$ paired data points). We only report concentration-runoff relationships that are statistically significant at $95 \%$ ( $p$-value $<0.05$ for all three parameters). If $C_{0}$ cannot be assumed to be zero (based on $p$-value $>0.05$ for fitted Eq. (1) $C_{0}$ value), we correct for atmospheric, spring, and/or hydrothermal inputs by subtracting the calculated $C_{0}$ value from the concentration-runoff relationship as shown schematically in Fig. 3. TDS $[\mathrm{mg} / \mathrm{L}]$ derived from the weathering of silicate rocks, which is a measure of total silicate chemical denudation, is calculated by weighting the concentrations by the molar mass of each major cation and $\mathrm{SiO}_{2}$ (e.g., Bouchez and Gaillardet, 2014) and correcting the concentration-runoff relationship for $C_{0}$. We also similarly calculate and correct concentration-runoff relationships for cation-equivalent (e.g., Gaillardet et al., 2011b), which is the charge-weighted concentration of positively charged cations $\left(\mathrm{Mg}^{2+}, \mathrm{Ca}^{2+}, \mathrm{K}^{+}\right.$, and $\left.\mathrm{Na}^{+}\right)$and compare them to the $\mathrm{HCO}_{3}{ }^{-}$results.

We calculate the absolute weathering potential $(\Delta \mathrm{WP})$ and normalized weathering potential ( $\left.W P_{\text {norm }}\right)$ using Eqs. (5) and (6). The observed weathering flux, $W_{o b s}$, is determined using Eq. (4) where $q$ is the median of the runoff distribution, with the range of weathering fluxes calculated for each catchment using the maximum and minimum 
observed runoff values that are paired to solute concentrations. The maximum weathering flux, $W_{\max }$, is determined as the product of $C_{\max }$ and $D w$.

In addition to deriving $D w$ values from fitting concentration-runoff relationships from all available data, we also derive $D w$ values using single concentration-runoff pairs for each catchment. Maher and Chamberlain (2014) noted the lack of long-term monitoring available to fully constrain mechanisms driving the distribution of weathering efficiency ( $D w$ values) in modern systems. Previous work using this solute production framework took the approach of assuming $C_{\max }$ values for global river datasets to derive flux-weighted $D w$ values from single concentration-runoff pairs (von Blanckenburg et al., 2015), assuming that time-averaging of discharge and concentrations in existing global river datasets were accurate (e.g., Gaillardet et al., 1999; Moon et al., 2014; Goldsmith et al., 2015). The advantage of using the single flux-averaged concentration-runoff pair for this analysis is that hysteresis (on storm event or seasonal timescales; e.g., Chanat et al., 2002; Moquet et al., 2015) is accounted for, rather than resulting in greater uncertainty around the solute production parameters derived from the concentration-runoff relationship fit (see above for fitting methods). However, recent work has shown, using an inverse modeling and bootstrapping approaches, that estimates of fluxes using datasets result in overestimation of global weathering fluxes (Moon et al., 2014, see their Fig. 8). Thus, we pair flux-weighted concentrations using all available data with average runoff values from each catchment. For each sample group, we calculate Cmax as the 95th percentile (e.g., Dixon and von Blanckenburg, 2012; Maher and Chamberlain, 2014; von Blanckenburg et al., 2015). Assuming $C_{0}$ is zero, Eq. (3) is solved for flux-weighted $D w$ 
values. The results from the single concentration-runoff pairs are compared to those derived by fitting concentration-runoff relationships.

\section{Statistics of sample groups}

We report and illustrate the variability of $C_{\max }, C_{0^{-}}$-corrected $C_{\max }, D w$, and $W_{\max }$ values for each sample group of basalt and granitic catchments in Table and Figures. We use box and whisker plots with mean, median, interquartile range (IQR) and 95\% confidence intervals. Summary statistics are necessary because (1) distributions in $D w$ and $C_{\max }$ are not normally distributed (typically positively skewed) within sample groups (Maher and Chamberlain, 2014), and the distribution in q observed within each catchment also tends to be non-normal; and (2) the rational forms of Eqs. (1) and (2) result in asymmetric propagated errors (cf. discussion in von Blanckenburg et al., 2015) when calculating $W_{\max }$ from derived values of $C_{\max }$ and $D w$. It is notable that although we only include catchment fits with statistically significant $D w, C_{\max }$, and $C_{0}$ parameters $(95 \%, p>0.05)$, the estimated uncertainty for each parameter can vary by an order of magnitude or more depending on the goodness of fit and absolute values. Uncertainty in $C_{0}$ is propagated in quadrature when correcting the $C_{\max }$ values of concentration-runoff relationships for individual catchments.

Linear regressions between mean weathering temperature and the derived parameters $(C \max$ and $D w)$ are illustrated for significant $(p$-value $<0.05)$ relationships only. We report coefficients of correlation, and slopes between Cmax and temperature. The mean water temperature of the collected samples used to derive the concentrationrunoff fits was selected to represent the mean weathering temperature of each catchment. 


\section{Saturation indices}

To evaluate thermodynamic controls on $C_{\max }$, we calculate the saturation index according to the ion activity product $(I A P)$ and the equilibrium constant $K$ (i.e., $\log (I A P / K))$ for calcium and sodium feldspar end-members and key secondary minerals. When $\log (I A P / K)=0$, the fluid is in equilibrium with the mineral. When $\log (I A P / K)<0$, the fluid is undersaturated relative to the mineral, and when $\log (I A P / K)>0$, the fluid is supersaturated relative to the mineral. Saturation index calculations were performed in Geochemist's Workbench (Bethke and Yeakel, 2015) using the Thermoddem database (version: 1lv12; Blanc et al., 2012; Marty et al., 2015) at the temperature of sample collection. Approximately $25 \%$ of the data considered in this study includes aluminum concentration data required for the speciation and saturation index calculations.

Potassium feldspar saturation index calculations were not included due to a lack of potassium solute data $(<8 \%$ of data). We include all available samples with $\mathrm{pH}$ and aluminum concentrations $(n=1,952)$ from the USGS NWIS database from basaltic and granitic catchments as well as from the Icelandic basaltic catchments (Eiriksdottir et al., 2013, 2015).

\subsubsection{Results}

\section{Concentration-discharge relationships}

Concentration-runoff $(C-q)$ fits for all catchments in our compilation are illustrated in Fig. 4 and reported in Tables A2-A8. Many statistically significant $C-q$ relationships for $\mathrm{HCO}_{3}^{-}(51 \%, \mathrm{n}=24), \mathrm{Ca}^{2+}(50 \%, \mathrm{n}=24)$, and $\mathrm{Mg}^{2+}(40 \%, \mathrm{n}=18)$ (and 
by extension TDS and cation-equivalent) required $C_{0}$ corrections (Tables A3-A8). In contrast, proportionally fewer $\mathrm{SiO}_{2}(\mathrm{aq})(28 \%, \mathrm{n}=12)$ and $\mathrm{Na}^{*}(20 \%, \mathrm{n}=8)$ statistically significant relationships required a $C_{0}$ correction (Table A2). For the $\mathrm{SiO}_{2}$ (aq) $C-q$ relationships, this likely reflects the fact that $\mathrm{SiO}_{2}(\mathrm{aq})$ is a primary recorder of silicate weathering (White and Blum, 1995; Waldbauer and Chamberlain, 2005; Maher and Chamberlain, 2014) with minimal $C_{0}$ contributions (Maher, 2011). Statistically significant $C_{0}$ values $\left(C_{0}>0\right)$ for $\mathrm{SiO}_{2}(\mathrm{aq})$ and $\mathrm{Na}^{*}$ (Tables $\mathrm{A} 2$ and A5) proportionally account for less of the uncorrected $C_{\max }$ values relative to $\mathrm{Ca}^{2+}, \mathrm{Mg}^{2+}$ and $\mathrm{HCO}_{3}{ }^{-}$(Tables A3, A4 and A6; see also Fig. 4). Because we are interested in analyzing the weathering zone component of the solute load, in particular apparent controls on $W_{\max }$ (e.g., Dixon and von Blanckenburg, 2012; Maher and Chamberlain, 2014), we focus below on the $C_{0^{-}}$ corrected $C-q$ fits illustrated in Fig. 5. In addition, Fig. 6 illustrates the derivation of the flux-weighted $D w$ values reported in Table A9 for single $C-q$ pairs for each catchment, assuming sample group $C_{\max }$ values (95th percentiles) derived by calculating fluxweighted average concentrations for each catchment.

\section{Chemostatic concentration $\left(C_{\max }\right)$}

The distribution of $C_{\max }$ values demonstrates that the net weathering stoichiometry of the primary lithology plays a first order control on setting $C_{\max }$ (Fig. 5). To the right of each panel in Fig. 5 shows distribution of the $C_{\max }$ summary statistics for each group (Table 1). Also annotated for each dissolved species is the ratio of the mean basalt $C_{\max }$ to the mean granite $C_{\max }$. 
Based on a comparison of Dessert et al. (2003) and Gaillardet et al. (1999) datasets, Maher and Chamberlain (2014) estimated that basaltic $C_{\max }$ values are approximately 1.5 times greater than $C_{\max }$ values of large rivers, assuming similar $D w$ distributions (discussed below). The results presented in Fig. 5 (and Table 1) suggest that this estimate was of the correct magnitude and varies depending on the dissolved species considered. The mean $C \max$ value for basaltic catchment $\mathrm{SiO}_{2}(\mathrm{aq})$ is 1.6 times higher than that of granite (324 vs. $209 \mu \mathrm{mol} / \mathrm{L}$; Table 1), similar to the values derived for $\mathrm{Na}^{*}$ (1.6), $\mathrm{HCO}_{3}{ }^{-}(1.3)$, TDS (1.8), and cation-equivalent (1.8). The difference in $C_{\max }$ suggested by the $\mathrm{SiO}_{2}(\mathrm{aq})$ values is bracketed by $\mathrm{Ca}^{2+}(1.2)$ and $\mathrm{Mg}^{2+}(2.1)$, reflecting the mafic (i.e., Mg-rich) nature of basaltic bedrock and the net stoichiometry of the weathering reactions (discussed in detail below), or the secondary mineral assemblage (e.g., Bouchez and Gaillardet, 2014).

The $\mathrm{SiO}_{2}$ (aq) $C_{\max }$ values for both basalt $(324 \mu \mathrm{mol} / \mathrm{L})$ and granite $(209 \mu \mathrm{mol} / \mathrm{L})$ catchments are lower than the $C_{\max }$ value originally suggested by Maher and Chamberlain (2014), who used the 95th percentile of annually averaged datasets (Gaillardet et al., 1999) to infer a large river $\mathrm{SiO}_{2}(\mathrm{aq}) C_{\max }$ of $375 \mu \mathrm{mol} / \mathrm{L}$. A population of annually averaged concentration data biases the apparent Cmax values toward higher values because observations of lower concentrations at high runoff are sparse (cf. Godsey et al., 2009; Moon et al., 2014; von Blanckenburg et al., 2015; Dessert et al., 2015). Similarly, by calculating flux-weighted average concentrations for all catchments and deriving $C_{\max }$ values (using the 95th percentile; Table A9; Fig. 6) for each sample group, we find $C_{\max }$ values that are higher than those derived using the concentration-discharge relationships. However, based upon the flux-weighted concentrations, the apparent $\mathrm{SiO}_{2}(\mathrm{aq}) C_{\max }$ value 
for basalt is 1.3 times that of granite $(455 \mu \mathrm{mol} / \mathrm{L}$ vs. $353 \mu \mathrm{mol} / \mathrm{L}$; Table 1$)$, which is of a similar magnitude to the mean $C_{\max }$ difference derived using the individual river concentration-discharge relationships. Importantly, this suggests that both methods produce comparable weatherability estimates at low runoff (discussed further below). Differences in Cmax values between basalt and granite catchments of approximately a 1.3 to 1.9 factor remain for $\mathrm{HCO}_{3}^{-}$(1.7), TDS (1.4), and cation-equivalent (1.7) using the flux-weighted concentrations (Table 1). The spread observed in basalt and granite catchments (Fig. 5) $C_{\max }$ values may be due to variations in soil $p \mathrm{CO}_{2}$, bedrock age, temperature, effects of subsurface structure on flow regime, and additional geomorphic properties (Godsey et al., 2009; Clow and Mast, 2010; Maher, 2011; Moon et al., 2014; Torres et al., 2015).

The effect of temperature (Table A1) on Cmax is assessed in Fig. 7. We find that only $C_{\max }$ values for $\mathrm{SiO}_{2}(\mathrm{aq})$ and $\mathrm{Na}^{*}$ (granite only) have statistically significant ( $p$ values $<0.05$ ) positive relationships with average water (i.e., weathering) temperature, with low coefficients of determination $\left(\mathrm{r}^{2}<0.4\right)$. The positive slopes of the temperature$C_{\max }\left(C_{0^{-}}\right.$-corrected $\left.C_{\max }\right)$ relationship are reported in Fig. 7 and suggest a weak, but statistically significant temperature control for $\mathrm{SiO}_{2}(\mathrm{aq})$ and $\mathrm{Na}^{*}$ only. These trends are consistent with observations that dissolution rates increase with increasing temperature following Arrhenius-type relationships (e.g., Oelkers and Gíslason, 2001; Gíslason and Oelkers, 2003; Eiriksdottir et al., 2013; Li et al., 2016). Since solute fluxes are driven by runoff (Eiriksdottir et al., 2013), these results emphasize the importance of evaluating and considering concentration-discharge behavior in weathering flux datasets and compilations (e.g., Moon et al., 2014). Runoff and temperature are inherently positively 
correlated in most datasets covering large ranges in latitudinal settings, such as those used to derive Arrhenius-type weathering relationships (e.g., Dessert et al., 2003; Li et al., 2016).

Lastly, we acknowledge that the $C_{\max }$ values from this analysis may not be directly applied to heterogeneous (non-monolithologic) catchments or global rivers (e.g., Gaillardet et al., 1999; Maher and Chamberlain, 2014; Moon et al., 2014) due to the same factors listed above and different proportions of silicate weathering. Further work with databases combining the areal extent of silicate bedrock with large river solute data including water temperature data (e.g., Moon et al., 2007; 2009; Jansen et al., 2010; Moosdorf et al., 2011; Hartmann and Moosdorf, 2011, 2012; Hartmann et al., 2014b) will allow for direct comparison between the apparent contribution (via inverse methods) to the dissolved load chemistry by the silicate lithologies and bedrock-based lithologic distributions within catchments.

\section{Saturation indices of primary and secondary minerals}

The trends between granitic and basaltic catchments in the Cmax distributions (Fig. 5) may be controlled by the thermodynamics and the net stoichiometry of the primary silicate minerals (i.e., feldspars, olivine, and pyroxene) weathering to secondary minerals and generating solute (e.g., Schott et al., 2009; Navarre-Sitchler et al., 2013; Bouchez and Gaillardet, 2014). We propose that the dissolution of primary minerals and the approach to chemical equilibrium with secondary mineral assemblages formed in the weathering zone (e.g., Maher et al., 2009; Maher, 2010; Clow and Mast, 2010, 2011;

Maher and Chamberlain, 2014; Li et al., 2014; Maher and Druhan, 2014) controls solute 
concentration and $C_{\max }$ values for specific catchments. At present, few aluminum concentration data and/or bed-load X-ray diffraction data exist to determine the specific secondary minerals driving variations in Cmax between lithologic groups and under different climatic conditions.

Here, we use aluminum concentration data as available for the catchments analyzed in this study to derive saturation indices of primary and secondary minerals. Cmax values should reflect concentrations during base flow (i.e., low runoff), and the assumption that equilibrium with secondary phases is achieved given long flow paths (Maher, 2010, 2011). We also consider idealized end-member compositions whereas primary mineral compositions and assemblages can be highly variable, especially in catchments with hydrothermally altered bedrock. In addition, these speciation and saturation index calculations may be impacted by $\mathrm{CO}_{2}$ evasion in the stream channel (e.g., Wallin et al., 2011; Lauerwald et al., 2015), emphasizing the need for upslope monitoring of soil and groundwater solute chemistry (e.g., Kim et al., 2014) to determine controls on $C_{\max }$ values for individual catchments.

In Fig. 8, we compare histograms of basalt and granite saturation indices for feldspar end-members, typical secondary weathering aluminosilicate minerals (halloysite, gibbsite, imogolite, smectites ( $\mathrm{Ca}, \mathrm{Na}$ and $\mathrm{Mg}$ end-members) and kaolinite), amorphous silica, and calcite. We separately show the chemostatic catchments as solid bars in Fig. 8 . The histograms indicate that most samples are undersaturated with respect to endmember feldspars (albite and anorthite), amorphous silica and calcite, as well as for olivine and pyroxene minerals (not shown), in agreement with previous work (e.g., Bluth and Kump, 1994; Gíslason et al., 1996; Stefánsson and Gíslason, 2001; Stefánsson et al., 
2001; Oelkers and Gíslason, 2001; Jacobson et al., 2003; Eiriksdottir et al., 2013, 2015).

Chemostatic basalt catchments are most undersaturated with respect to feldspars compared to granitic catchments (discussed further below). This apparent higher degree of undersaturation observed for primary minerals (see feldspars in Fig. 8) in chemostatic catchments may suggest hydrologic thresholds on Cmax concentrations (Chanat et al., 2002; Eiriksdottir et al., 2013) as saturation state with respect to primary minerals tends to decrease with increasing discharge. Given this undersaturation with respect to primary minerals, the departure from equilibrium with respect to primary phases (feldspars (Fig. 8), as well as olivine and pyroxenes (not shown)), could be a factor in determining $C_{\max }$ concentrations, especially in granitic catchments. Despite this, as shown below, incorporation of elements into and equilibrium with secondary phases likely plays a controlling role on Cmax concentrations.

Importantly, all samples are oversaturated with respect to the clay minerals (halloysite, imogolite, smectites, and kaolinite) and gibbsite. This saturation with respect to metastable alluminosilicate secondary clays is expected and has been observed in both stream/river waters (e.g., Gíslason and Eugster, 1987; Bluth and Kump, 1994; Stefánsson and Gíslason, 2001; Eiriksdottir et al., 2013) and soils (Maher et al., 2009; White et al., 2009; Kim et al., 2014). Of the clay minerals, samples from both chemostatic and nonchemostatic catchments are closer to saturation $(\log (I A P / K=0)$ with halloysite (and imogolite), and highly supersaturated with respect to kaolinite and the smectite endmembers. Since halloysite and imogolite are thought to be metastable precursors (Stefánsson and Gíslason, 2001; Maher et al., 2009; White et al., 2009; Kim et al., 2014) and are closer to equilibrium compared to kaolinite or smectite (Fig. 8), this may justify 
the use of halloysite (or imogolite) in reaction path reactive transport modeling instead of kaolinite or smectite (e.g., Maher, 2011). Field observations demonstrate that multiple different secondary clay minerals co-exist in typical weathering profiles (e.g., White et al., 2009; Maher et al., 2009). In Fig. 9, we illustrate activity diagrams of the $\mathrm{Ca}-\mathrm{Na}$ and $\mathrm{Ca}-\mathrm{Mg}$ systems with kaolinite and smectite stability fields (for different assumed $\mathrm{SiO}_{2}$ (aq) activities and the appropriate smectite end-members). We plot all of the basalt and granite data with available $\mathrm{pH}$ and sufficient solute data (anions, cations and $\mathrm{SiO}_{2}(\mathrm{aq})$ ) for speciation. The data for basalts and granites plot between the phase boundaries (Fig. 9), confirming previous work suggesting possible equilibrium between the more stable secondary phases of kaolinite and smectite (e.g., Bluth and Kump, 1994; Kump et al., 2000).

For feldspars, amorphous silica, and calcite, chemostatic basalt catchments are further from saturation compared to non-chemostatic catchments (filled red bars in histograms of Fig. 8). Whereas primary feldspars are not expected to be stable at surface temperatures, undersaturation of amorphous silica, and calcite is surprising given the high reactive surface areas of basaltic systems (Eiriksdottir et al., 2013). This may result from several factors, including the possibility that rapid weathering of basaltic catchments has reduced the amount of primary mineral (the reactant) in the weathering zone. In addition, some samples, mostly chemostatic granitic catchments, are near saturation with respect to calcite. This is not unexpected because trace calcite in granitic bedrock is commonly observed, as is new calcite precipitation in many seasonally arid/semi-arid granitic weathering systems (e.g., Wang et al., 1996; Amundson et al., 1996; Blum et al., 1998; 
White et al., 1999b; Hartmann and Moosdorf, 2011; Kim et al., 2014; Jacobson et al., 2015).

Cumulatively, these observations corroborate observations of the mineral assemblages in weathering profiles from silicate dominated systems (e.g., Eberl, 1984; Steefel and Van Cappellen, 1990; White et al., 1999a, 2009; Maher et al., 2009) and suggest that solute concentrations are influenced by the thermodynamic potential for primary mineral dissolution and secondary mineral precipitation - the stoichiometry of which consequently may determine the catchment $C_{\max }$ values for various solutes (Maher, 2011; Maher and Chamberlain, 2014). The nature of this analysis is preliminary given limited available datasets. Future acquisition of accurate aluminum concentration and $\mathrm{pH}$ data (e.g., Eiriksdottir et al., 2013, 2015) is vital for speciation calculations of solute chemistry measurements in this manner and for informing further reaction path modeling of soil zone weathering (e.g., Maher, 2011).

\section{Comparison of Damköhler coefficients}

The Damköhler coefficient $(D w)$ provides a metric to extract the resistance to dilution from the concentration-discharge relationship (Maher, 2011; Maher and Chamberlain, 2014). Higher Dw values would correspond to catchments that start to show dilution at higher discharge values, similar to more negative $b$-values in power-law $C-Q$ relationships (e.g., Godsey et al., 2009; Moon et al., 2014; Torres et al., 2015) (Fig. 2a). Due to different thermodynamic (i.e., dissolution/precipitation) processes and stoichiometric constraints associated with Cmax, along with kinetic effects at increasing runoff, $D w$ values should differ among elements. $D w$ values capture both the physical 
length scale setting fluid residence times and the reactivity of the weathering reactions. Thus, $D w$ values have been linked to erosion rates, which determine the abundance of fresh minerals at the surface and hence the reactivity (Maher and Chamberlain, 2014). Increased erosion rates remove highly weathered material from the weathering zone, exposing new material at the surface and increasing reactive surface areas (e.g., Waldbauer and Chamberlain, 2005; West, 2012). Erosion may further alter the topography and drainage structure, resulting in different porosity and permeability distributions. Thus, the observed intra-lithology spread in Dw distributions may be driven by these variations in flow path porosity/permeability (e.g., White et al., 1996, 1999a, 2001, 2005, 2009, Jacobson et al., 2002; Maher et al., 2009; Navarre-Sitchler et al., 2009, 2011, 2013, 2015; Sak et al., 2010; Ryu et al., 2011; Parry et al., 2015) and/or erosion rates (e.g., Chamberlain et al., 2005; Waldbauer and Chamberlain, 2005; Hren et al., 2007; Porder et al., 2007; Eiriksdottir et al., 2008; Moon et al., 2011; West, 2012; Torres et al., 2015; Lee et al., 2015). Finally, on seasonal timescales ion-exchange on clay minerals or organic matter surfaces can serve as a temporary reservoir (Sverdrup and Warfvinge, 1988; White and Blum, 1995; Chorover and Sposito, 1995; Chorover et al., 2007; Clow and Mast, 2010; Andrews et al., 2016) and decouple the fluid residence times from the solute residence times, although for this study, we limit our dataset to sites with sufficient temporal coverage to negate seasonal biases.

In Fig. 10, we show cross-plots of $D w$ values for different solutes of individual catchments (for statistically significant $C-q$ relationships only). Plotted above and to the right are $D w$ distributions for each sample group as derived in Fig. 5. These results demonstrate that among all solutes the distribution of Dw values is positively skewed. 
Observation of skewed distributions using the annually averaged Gaillardet et al. (1999) $\mathrm{SiO}_{2}(\mathrm{aq})$ data is consistent with previous work by Maher and Chamberlain (2014) and von Blanckenburg et al. (2015). However, because these studies used a $C_{\max }$ value of 375 $\mu \mathrm{mol} / \mathrm{L}$ for all catchments and used annually averaged datasets (see above), these studies underestimate absolute $D w$ values. Consequently, we find for basalt and granite catchments mean $\mathrm{SiO}_{2}$ (aq) $D w$ values of $3.47 \mathrm{~m} / \mathrm{yr}$ and $1.49 \mathrm{~m} / \mathrm{yr}$, respectively (Table 1), compared to $0.21 \mathrm{~m} / \mathrm{yr}$ for large rivers (cf. von Blanckenburg et al., 2015, their Table S6 corrected for the scaling factor). An additional, possible reason for this discrepancy may be that large rivers may not be merely a representation of mixing (and dilution) from small catchments for $\mathrm{SiO}_{2}(\mathrm{aq})$. Instead, processes in flood plains and modern dams/lakes may provide temporary storage (i.e., buffering the concentration) and/or sequestration (through biological sedimentation) of $\mathrm{SiO}_{2}$ (aq) (Admiraal et al., 1990; Dürr et al., 2011; Hartmann et al., 2011; Lupker et al., 2012; Bouchez et al., 2012; Lauerwald et al., 2013; Maavara et al., 2014). Further, changes in anthropogenic nutrient inputs (Hartmann et al., 2007) can cause $\mathrm{SiO}_{2}$ (aq) levels to vary with time when considering longer term as well as seasonal trends (Hartmann et al., 2011). Future longitudinal sampling campaigns along major rivers that integrate smaller silicate catchments may help explain this potential discrepancy (see Amazon River compilations by Bouchez et al., 2014; Torres et al., 2015; Moquet et al., 2015).

The cross-plots in Fig. 10 demonstrate that resistance to dilution is not uniform among solutes for a given catchment or within sample groups. The $\mathrm{C}-\mathrm{q}$ relationships for $\mathrm{SiO}_{2}(\mathrm{aq})$ for both basalts and granites are characterized by higher Dw values for some catchments compared to the base cations $\left(\mathrm{Mg}^{2+}, \mathrm{Ca}^{2+}\right.$, and $\left.\mathrm{Na}^{*}\right)$ and $\mathrm{HCO}_{3}{ }^{-}$(Figs. 5 and 
10a-d). This potential bias appears to be greatest among basaltic catchments (red basalt catchments in the lower right of Fig. 10a-d). However, a majority of catchments are within a factor of two of each other when comparing $\mathrm{SiO}_{2}(\mathrm{aq})$-derived $\mathrm{Dw}$ values to other solutes (diagonal dashed lines in Fig. 10). The result that some catchments demonstrate higher $\mathrm{SiO}_{2}$ (aq) $D w$ values is consistent with power-law b-values from Moon et al. (2014) for large rivers, which had a median $\mathrm{SiO}_{2}$ (aq) value of -0.06 , compared to median values of -0.12 to -0.24 for other solute species (cations and $\mathrm{HCO}_{3}{ }^{-}$). Godsey et al. (2009) and Torres et al. (2015) also observed $\mathrm{SiO}_{2}$ (aq) relationships typically closer to chemostatic values ( $b$-values approaching $\sim 0$ ).

Across all concentration-discharge fits, basaltic catchments typically have greater Dw values. Mean Dw values of basaltic catchments are two to five times higher than granitic catchments (Table 1). However, observed Dw values for $\mathrm{Mg}^{2+}$ and $\mathrm{Ca}^{2+}$ are similar, despite large differences in the $\mathrm{Mg}^{2+}$ and $\mathrm{Ca}^{2+} C_{\max }$ values between basalts and granites (shown above) (Fig. 10g), suggesting similar behavior of these cations during primary mineral dissolution and secondary mineral precipitation, and dilution processes, despite differences in absolute values of $C_{\max }$ driven by the net stoichiometry of the weathering reactions. In addition, cation-equivalent and $\mathrm{HCO}_{3}{ }^{-}$, which may be influenced differently by ion exchange processes, have consistently similar $D w$ values, with only 8 of 37 catchments having $D w$ values that differ by more than a factor of two (Fig. 10f). Finally, we also analyzed the relationship between $D w$ and temperature. We find no statistically significant $(\mathrm{p}<0.05)$ correlations for any solutes between $D w$ and the average weathering temperature, shown as scatterplots in Fig. 11. 


\section{Weathering potential}

The results above demonstrate that basalt catchments, with higher $D w$ and $C_{\max }$ values than granite catchments, have a greater absolute capacity to increase weathering rates with increased runoff (i.e., larger $\Delta W P$ ). This implies that increases in runoff result in much larger absolute increases in weathering fluxes in basaltic catchments (Fig. 2b). The absolute departure of catchment weathering fluxes from a theoretical maximum (i.e., $\left.\Delta W P=W_{\max }-W_{o b s}\right)$ is dependent on the derived $D w$ and $C_{\max }$ values, which combine to set $W_{\max }$, and on the runoff distribution, which sets Wobs. Using $\mathrm{SiO}_{2}(\mathrm{aq})$ and $\mathrm{HCO}_{3}{ }^{-}$ catchment fits, we show in Fig. 12 that basaltic catchments have a higher $\Delta W P$ relative to granitic catchments (y-axis). Basalts have higher and more positively skewed $D w$ and higher $C_{\max }$ distributions, resulting in higher $W_{\max }$ values (Fig. 12; Table 1), implying that both stoichiometric and thermodynamic effects and resistance to dilution result in a greater weathering potential for basalts. At equivalent runoff distributions, this results in basaltic catchments having a higher normalized weathering potential $\left(W P_{\text {norm }}\right)$ due to higher $W_{\max }$ values than those in granitic catchments. Monitored basalt catchments included in this dataset are typically associated with higher $D w$ values, but also higher runoff distributions (Fig. 1) due to their proximity to coastal environments and potential for orographic effects (Bluth and Kump, 1994; Dessert et al., 2001, 2003; Hartmann et al., 2009; Gaillardet et al., 2011b; Maher and Chamberlain, 2014). Despite these effects, the fact that basaltic WPnorm values remain high at higher runoff illustrates the high reactivity of basalt catchments (Fig. 12).

These results imply that resistance to dilution at increasing runoff (higher $D w$ ) and stoichiometric considerations (higher $C_{\max }$ ) are lithology-dependent. Given that $C_{\max }$ 
values between basalts and granites vary by $<2$ orders of magnitude and $D w$ values vary by 4-5 orders of magnitude (Figs. 5 and 10), the differences in observed ( $\left.W_{o b s}\right)$ and maximum weathering $\left(W_{\max }\right)$ fluxes from basalt catchments are primarily driven by differences in $D w$. Although this dataset includes substantial variations in runoff, bedrock age, temperatures, and vegetation types within basalt and granite catchments, systematic testing of these two silicate lithology end-members under identical conditions is not yet possible (cf. Navarre-Sitchler and Brantley, 2007; Berner, 2008; Maher and Chamberlain, 2014). In Fig. 13a and b, we show the distribution of Wmax values derived from the $C-q$ fits (Fig. 5) for $\mathrm{SiO}_{2}$ (aq) and $\mathrm{HCO}_{3}{ }^{-}$. The mean basalt $\mathrm{SiO}_{2}$ (aq) Wmax is 3.6 times higher than for granites, whereas the mean basalt $\mathrm{HCO}_{3}{ }^{-} W_{\max }$ is 8.5 times higher than for granites (Table 1). These large differences in the $\mathrm{SiO}_{2}(\mathrm{aq})$ and $\mathrm{HCO}_{3}{ }^{-}$Wmax values are driven by differences in $D w$ values, which are 2.3 and 6.7 times greater, respectively, rather than $C_{\max }$ concentrations, which are only 1.6 and 1.3 times greater, respectively (Table 1). Saturation state histograms shown in Fig. 8 demonstrate that basaltic catchments are closer to equilibrium (more oversaturated) with some secondary minerals

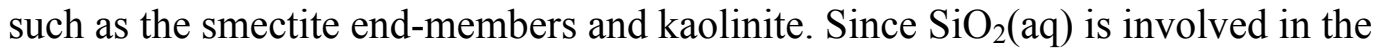
dissolution of primary minerals and the precipitation and dissolution of secondary minerals (i.e., secondary phase buffering), this may result in more $\mathrm{SiO}_{2}(\mathrm{aq})$ removal relative to $\mathrm{HCO}_{3}{ }^{-}$in basaltic catchments compared to granitic catchments, driving the lower $\mathrm{SiO}_{2}(\mathrm{aq}) D w$ differences between catchment types.

If the $W_{\max }$ value is set by both thermodynamic and dilution effects at high runoff, this may provide a mechanism to explain lithologic differences in "maximum" fluxes or weathering speed-limits observed across silicate catchments (Dixon and von 
Blanckenburg, 2012) (Fig. 13). However, for catchments that display near-chemostatic behavior, thermodynamic constraints $\left(C_{\max }\right)$ will control the chemical fluxes.

Furthermore, there are very few datasets with concentration measurements at very high runoff, resulting in a large degree of uncertainty in the averaged $W_{\max }$ values for both sample groups presented in Fig. 13. Acquisition of new datasets that include storm event concentration-discharge pairs, such as recently published dataset by Dessert et al. (2015) from Guadeloupe, will provide further constraints on extrapolated $W_{\max }$ values.

\subsubsection{Discussion}

\section{Runoff dependence of weatherability}

The utility of the analysis presented in this paper is to derive the distribution of $D w$ and $C_{\max }$ values of the silicate end-member lithologies. Unlike previous parameterizations of weathering laws (e.g., Dessert et al., 2003), we use paired discharge and solute concentration measurements for individual catchments - rather than annually averaged datasets - to parameterize lithology-specific $D w$ and $C_{\max }$ values. Although we did not analyze a globally comprehensive dataset of basaltic and granitic catchments, the first-order lithological trends are robust. Our results demonstrate that higher weathering rates in basaltic catchments relative to granites are driven by differing responses to increases in runoff, with basaltic catchments showing less dilution with increasing runoff (higher average $D w$ ). Further, the results suggest that thermodynamic constraints on weathering reactions, reflected in chemostatic concentrations $\left(C_{\max }\right)$ could explain higher concentrations in basaltic catchments at lower runoff compared to granitic catchments. For the remainder of the discussion, we primarily discuss the mean values derived from 
the analysis of $\mathrm{SiO}_{2}(\mathrm{aq})$ and $\mathrm{HCO}_{3}{ }^{-}$concentration-runoff fits, and the $2 \sigma$ uncertainty of these estimates is also reported.

We illustrate the annual modern global and regional runoff distributions in Fig. 14 by area-weighting the Dai and Trenberth (2002) global river discharge dataset. Comparison of basalt and granite datasets within our solute production framework directly quantifies the relative weatherability between the two major end-member silicate lithologies responsible for terrestrial silicate weathering (Bluth and Kump, 1994; White and Blum, 1995; Kump and Arthur, 1997; Horton et al., 1999; Kump et al., 2000; Dessert et al., 2001; Berner, 2006b, 2008; Navarre-Sitchler et al., 2015). We demonstrate how the relative weatherability, the ratio between the basalt and granite fluxes, varies spatially along the latitudes based on global runoff distribution (Fig. 14d). These results suggest that the relative weatherability is runoff-dependent, which likely varies through geologic time depending on the area and location of granite vs. more reactive basalt, continental configuration, and spatial changes in the runoff distribution.

Modern weathering observations have defined the range of expected basalt/granite weatherability values, in some cases attempting to control for climate and other influences (i.e., bedrock age, slope etc.; Horton et al., 1999; Hartmann, 2009; Hartmann et al., 2010; Hartmann and Moosdorf, 2011). Flux-runoff relationships derived by Bluth and Kump (1994), also plotted in Fig. 13, suggest basalt/granite weatherability of 1.5 (cf. Bluth and Kump, 1994, see Table 4; Kump et al., 2000), with slight variations with changing runoff. Similarly, synthesis of weathering fluxes from Japan suggests that the average basalt/granite weatherability is 1.67 , ranging from $\sim 1$ to $\sim 6$, corresponding to steep and flat slopes respectively (cf. Hartmann, 2009; Hartmann et al., 
2010; Hartmann and Moosdorf, 2011). By investigating proximal catchments with the same runoff distributions, Horton et al. (1999) suggested an andesite/granite weatherability of $\sim 1.5$ to 5 .

In contrast, carbon cycle models have generally assumed invariant basalt/granite weatherability through time. For example, using data from Dessert et al. (2001), Berner (2006b) estimated that volcanic (basaltic) silicate weathering is $\sim 5$ times that of plutonic (granitic), with bounds of 2 to 10, as included into GEOCARBSULF (e.g., Royer et al., 2014). Subsequent sensitivity analysis of GEOCARBSULF indicated that the lower bound of $\sim 2$ is likely more realistic considering requirements for seawater composition and reconstructions of $p \mathrm{CO}_{2}$ during the Mesozoic (Berner, 2008). Notably, the average flux-runoff curves from this analysis (solid red and blue lines in Fig. 13a,b) diverge from the Bluth and Kump (1994) relationships (dashed lines) at high runoff due to the mathematical formulation of the relationships (power-law vs. rational). Given that at an individual catchment scale, plateaus in weathering fluxes do occur at high runoff (e.g., Maher, 2011; Torres et al., 2015), the mathematical formulation of the solute production model employed here appears to capture both chemostatic and dilution processes adequately. As shown in Fig. 14a for $\mathrm{HCO}_{3}{ }^{-}$fluxes, because the modern global runoff distribution primarily lies between the end-members set by Wmax and Cmax, the derived weatherability is 2.2 at global mean runoff.

Higher area-normalized weathering rates and maximum limits on weathering fluxes for basaltic catchments, relative to granites (Fig. 13a,b), are primarily driven by higher $D w$ values and also higher $C_{\max }$ (see Results). Thus, depending on the underlying runoff distribution, weatherability is set by both $C_{\max }$ and $W_{\max }$ (Fig. 14a). For example, at 
modern global mean runoff values of $0.344 \mathrm{~m} / \mathrm{yr}(0.117-0.409,2 \sigma)$, basalt/granite weatherability is $2.2(1.3-3.7,2 \sigma)$ for $\mathrm{HCO}_{3}{ }^{-}$fluxes and $1.7(1.6-2.1,2 \sigma)$ for $\mathrm{SiO}_{2}(\mathrm{aq})$ fluxes (see red horizontal line in Fig. 9d). This difference is driven by a higher extrapolated weatherability (from derived Wmax values) using $\mathrm{HCO} 3-$ fluxes at high runoff. Notably, these calculations agree with basalt/granite weatherability calculated using the flux-weighted Dw values derived using the single $C-q$ pairs (Fig. 6). That method suggests a global mean runoff basalt/granite weatherability is $2.3(1.7-3.6,2 \sigma)$ for $\mathrm{HCO}_{3}{ }^{-}$fluxes and $1.7(1.3-2.4,2 \sigma)$ for $\mathrm{SiO}_{2}$ (aq) fluxes (Table 1).

Under this framework end-member plateaus occur at both runoff extremes. At low runoff, weatherability is only set by the difference in chemostatic concentrations $\left(C_{\max }\right)$ shown in Fig. 5. The mean $\mathrm{SiO}_{2}(\mathrm{aq})$ and $\mathrm{HCO}_{3}{ }^{-}$basalt/granite weatherability at low runoff (approximately $\mathrm{q}<10-2 \mathrm{~m} / \mathrm{yr}$ ) is 1.6 and 1.3, respectively (Table 1, Figs. 5 and 14a). In contrast, apparent mean $W_{\max }$ values suggest basalt/granite weatherability of 8.5 for $\mathrm{HCO}_{3}{ }^{-}$and 3.6 for $\mathrm{SiO}_{2}(\mathrm{aq}$ ) at very high runoff (approximately $>30 \mathrm{~m} / \mathrm{yr}$; Table 1, Fig. 14a). The higher basalt/granite weatherability at high runoff for $\mathrm{HCO}_{3}{ }^{-}$is primarily driven by the 6.7-fold difference between average basalt vs. granite Dw values, compared to a lesser 2.3-fold difference derived from $\mathrm{SiO}_{2}$ (aq) fluxes (Table 1). This inference of runoff-dependent basalt/granite weatherability presented in Fig. 14 implies that future carbon cycle modeling, in addition to influences of temperature (Li et al., 2016), should not necessarily assume invariant basalt/granite weatherability through time. 


\section{Dw, weatherability, and a variable silicate weathering feedback}

Above, we demonstrate that the weatherability of the surface of the Earth is runoff-dependent under our modeling framework, with modern mean runoff primarily spanning the transition in weatherability between thermodynamic and kinetic limitations. To describe the functional form of the silicate weathering negative feedback, previous work has parameterized global terrestrial weatherability (Kump and Arthur, 1997) with adjustable parameters that relate the silicate weathering flux to climate, usually pCO2 and runoff (e.g., Berner, 2006a, 2008; Zeebe, 2012; Royer et al., 2014; Mills et al., 2014b). These adjustable parameters determine the total weathering flux according to the strength of the silicate weathering negative feedback and the dependence on atmospheric $p \mathrm{CO}_{2}$ and/or climate. Often, in 0-D models, global weathering fluxes (Fsil) are parameterized as proportional to climate through $p \mathrm{CO}_{2}$; for example: $F$ sil $=k \times\left[p \mathrm{CO}_{2}\right]^{n}$ (Uchikawa and Zeebe, 2008; Zeebe, 2012; Mills et al., 2014b), where $\mathrm{k}$ is the weathering time constant and $\mathrm{n}$ encapsulates a non-linear response to climate. Together, $k$ and $n$ modify the strength of the weathering feedback (Schwartzman and Volk, 1989; Mills et al., 2014a; Caves et al., 2016). Globally, although weathering fluxes are determined by runoff because weatherability is modified by the overlying runoff distribution (Fig. 14), the strength of the feedback (the $k$ and $n$ terms) is also dependent on runoff. To relate the weatherability framework developed here to global feedback parameters (calibrated values of $\mathrm{k}$ and $\mathrm{n}$ ) requires knowledge of both the time-varying spatial distribution of silicate lithologies and changes in runoff patterns set by changes in atmospheric circulation and continental configuration. Assuming that increases in global runoff are positively correlated with increasing $p \mathrm{CO}_{2}$ (Otto-Bliesner, 1995; Gibbs et al., 1999; 
Pierrehumbert, 2002; Manabe et al., 2004), our solute production framework provides a quantitative method to parameterize formulations of the negative feedback in both $0-\mathrm{D}$ carbon cycle models and spatially explicit weathering models. Thus, the strength of the negative feedback is set by the interaction between the $D w$ values of silicate bedrock catchments and the spatial runoff distribution.

Given changes in continental configuration, eruptions of large igneous provinces, and changes in tectonic uplift, global $D w$ distributions must be non-stationary through geologic time. We propose here that a variable silicate weathering feedback may be driven by shifts in the $D w$ distribution of silicate catchments globally. Further, atmospheric circulation drives large variations in runoff across the Earth's surface today (Fig. 14c); thus, changes in climate that affect this circulation will vary the spatial pattern of runoff, further altering the strength of the negative feedback.

To demonstrate how the spatial distribution of lithology and runoff interact to determine basalt/granite weatherability, we plot in Fig. 14c, $d$ the modern weatherability as a function of latitude. We calculate this for modern basalt catchments using the modern latitudinal runoff distribution from Dai and Trenberth (2002) (see Fig. 14 caption for details). In this figure, because runoff substantially varies latitudinally (Fig. 14c), weatherability also varies latitudinally and displays large, 50\% variability. Over geologic timescales, if the proportion of basalt relative to granite changes (black lines Fig. 14d), weatherability must also change, with the largest changes occurring in the tropics due to high runoff. Thus, for example, the eruption of a large igneous province in the tropics should have a much larger effect on global weathering than a similarly sized eruption in subsiding portions of Hadley cells (Kent and Muttoni, 2008, 2013). Similarly, 
changes in climate that alter the distribution of runoff (such as Hadley cell expansion, shifting mid-latitude westerlies, etc.) would also produce changes in weatherability without necessarily a change in the areal distribution of lithologies. This view of weatherability contrasts with that presented in Fig. 14a. Here, we derive weatherability for global average runoff, which—due to energetic constraints (Pierrehumbert, 2002)— cannot change dramatically. Thus, 0 -D models of weathering are potentially limited in their ability to capture large changes in weatherability due to changes in the spatial distribution of runoff and/or lithology, even if global averages remain constant.

Changes in global basalt/granite weatherability due to variations in runoff and in the distribution of bedrock silicate lithologies indicate that weatherability can change on both short and very long timescales (Fig. 14d). For example, basalt/granite weatherability increases at higher runoff; therefore, rapid climate change during greenhouse climates, such as in the early Eocene or Cretaceous, may cause pronounced changes in weatherability as runoff intensity and distribution changes (Fig. 14a). Thus, across a carbon-cycle perturbation such as the PETM-which witnessed large-scale changes in hydrology and runoff (Bolle and Adatte, 2001; Bowen et al., 2004; Pagani et al., 2006; Foreman et al., 2012) against a background greenhouse climate state-weatherability cannot be assumed constant. An increase in weatherability would tend to shorten the duration of the carbon cycle perturbation. Across such perturbations, globally averaged runoff may change, though likely not substantially (cf. Pierrehumbert, 2002; Manabe et al., 2004). However, if the spatial distribution of runoff changes dramatically (e.g., Pagani et al., 2006; Tipple et al., 2011; Foreman et al., 2012), this would drive larger 
changes in the basalt/granite weatherability relative to changes expected based solely on globally-averaged runoff.

Similarly, on longer timescales, as continental configuration and climate change, the spatial interactions between these two effects will affect weatherability and, hence, the strength of the negative feedback. These effects are likely to be greater than those caused by changes in the global average runoff given that spatially runoff varies substantially. Indeed, previous studies have suggested that changes in global silicate weathering fluxes could be driven by the interaction of continental configuration and sea level with the overlying runoff distribution, as determined by atmospheric circulation, over both short $\left(10^{3}-10^{5} \mathrm{yr}\right)$ and long $\left(>10^{6} \mathrm{yr}\right)$ timescales (e.g., Gibbs and Kump, 1994; Gibbs et al., 1999; Ludwig et al., 1999; Munhoven, 2002; Donnadieu et al., 2004; Goddéris et al., 2008; Kent and Muttoni, 2008; Le Hir et al., 2009; Mills et al., 2011, 2013; Jagoutz et al., 2016).

The spatial sensitivity of the weathering feedback points to the importance of further development of spatially explicit weathering models coupled to or driven by global climate models (e.g., Munhoven, 2002; Goddéris et al., 2008; Lefebvre et al., 2013; Goll et al., 2014; von Blanckenburg et al., 2015) that will allow us to better quantify how the interaction between lithologic exposure, tectonic processes, configuration of continents, and climate sets the strength of the silicate weathering feedback through time. Though we have focused here on the role of lithology in determining the efficiency of silicate weathering, exposure of more rapidly eroding areas (e.g., higher Dw values) due to tectonic uplift (e.g., Waldbauer and Chamberlain, 2005; von Blanckenburg, 2005; West et al., 2005; Hilley et al., 2010; Norton and von 
Blanckenburg, 2010; West, 2012) may also provide a mechanism for varying the strength of the silicate weathering feedback (Maher and Chamberlain, 2014; Caves et al., 2016).

Because the weatherability of the Earth's surface can vary through geologic time, paleogeographic and paleotopographic reconstructions are intrinsically important for placing bounds on the strength of the silicate weathering feedback. Constraining the strength of the silicate weathering feedback through time will require the use of paleoclimate model simulations to determine past runoff distributions under changing continental configurations (e.g.Gibbs et al., 1999; Munhoven, 2002; Goddéris et al., 2008; von Blanckenburg et al., 2015), in combination with: (1) reconstructing the interaction of large orogenic belts with climate (e.g., Montgomery et al., 2001; Rowley and Currie, 2006; Mulch and Chamberlain, 2006; DeCelles et al., 2007; Garzione et al., 2008; Mix et al., 2011, 2016; Caves et al., 2014, 2015), (2) the inferred erosion rates of orogenic belts (e.g., Drever and Zobrist, 1992; Willett, 1999; Kirchner et al., 2001; Hilley et al., 2010; Willenbring and von Blanckenburg, 2010; Moon et al., 2011; Moore et al., 2013; Willett et al., 2014; Lee et al., 2015), (3) the spatial distribution and evolution of shielding soils (e.g., Taylor and Blum, 1995; Chamberlain et al., 2005; Porder et al., 2007; Goddéris et al., 2008; Kent and Muttoni, 2013; Hartmann et al., 2014a; Minasny et al., 2015; St. Clair et al., 2015), (4) the interaction of climate and erosional processes on basin evolution to determine reactive flow path length and subsurface permability (e.g., Rempe and Dietrich, 2014; St. Clair et al., 2015), and (5) the areal extent and spatial configuration of rapidly eroding areas (e.g., Bluth and Kump, 1991; Gibbs et al., 1999; Kent and Muttoni, 2008; 2013; Molnar and Cronin, 2015; Jagoutz et al., 2016; Cox et al., 2016) through geologic time. 


\subsubsection{Conclusions}

We have shown using modern concentration-runoff relationships how hydrologic and lithologic controls combine to set weathering fluxes from catchments by applying the process-based model of Maher and Chamberlain (2014) to assess the weathering efficiency of individual catchments of the two silicate end-member lithologies, granites and basalts. Although our analysis is limited to the Northern Hemisphere and primarily mid-latitude North America, the dataset shows first-order trends in weathering efficiency and lithological controls. We find that the relative weatherability of basalt compared to granites is runoff dependent due to both the plateaus in weathering fluxes caused by dilution of solutes at high runoff and the thermodynamic controls at lower runoff. As a consequence, the weatherability of basalt relative to granites has likely not been constant over geologic time — as runoff and lithologic exposure changes spatially—and is perhaps not constant even on shorter timescales. In addition, when more directly comparable modern data becomes available, weatherability can be assessed under constant climate, soil age, and vegetation parameters using the framework presented in this paper. Finally, if the differences in bedrock weatherability can be extrapolated to the geologic past as presented here, then determining the global distribution and geographic configuration of lithologies, in addition to the interaction of topography with atmospheric circulation changes, will be essential in constraining the variable strength of the silicate weathering negative feedback and its role in controlling past atmospheric $p \mathrm{CO}_{2}$. 


\subsubsection{Acknowledgements}

We thank Julien Bouchez, Lee Kump and an anonymous reviewer for thorough and constructive reviews, and Associate Editor Anthony Dosseto for handling our manuscript. We thank Friedhelm von Blanckenburg, Jennifer L. Druhan, Kimberly V. Lau, and Matthew J. Winnick for stimulating comments and discussions, and Clayton Magill for assistance with Fig. 1b. We thank the USGS NWIS for making solute concentration and discharge data available. All data used in this study can be downloaded using the station numbers provided in Table A1. The raw datasets are available from the corresponding author on request. Example R code used for calculating $C-q$ relationships is provided in Appendix B. Daniel E. Ibarra is partially supported by a Stanford EDGESTEM Fellowship. Jeremy K. Caves is supported by a NSF Graduate Research Fellowship (Grant DGE-1147470) and a Stanford Graduate Fellowship. This work was funded by NSF Grant EAR-1254156 to Kate Maher. 


\subsubsection{References}

Admiraal W., Breugem P., Jacobs D. M. L. H. A. and De Ruyter Van Steveninck E. D. (1990) Fixation of dissolved silicate and sedimentation of biogenic silicate in the lower river Rhine during diatom blooms. Biogeochemistry 9, 175-185.

Amiotte-Suchet P. A. and Probst J.-L. (1993) $\mathrm{CO}_{2}$ flux consumed by chemicalweathering of continents-influences of drainage and lithology. C. R. Acad. Sci. Ser. II 317, 615-622.

Amundson R., Chadwick O., Kendall C., Wang Y. and DeNiro M. (1996) Isotopic evidence for shifts in atmospheric circulation patterns during the late Quaternary in mid-North America. Geology 24, 23-26.

Andrews M. G., Jacobson A. D., Lehn G. O., Horton T. W. and Craw D. (2016) Radiogenic and stable Sr isotope ratios $\left({ }^{87} \mathrm{Sr} /{ }^{86} \mathrm{Sr}, \delta^{88} /{ }^{86} \mathrm{Sr}\right)$ as tracers of riverine cation sources and biogeochemical cycling in the Milford Sound region of Fiordland, New Zealand. Geochim. Cosmochim. Acta 173, 284-303.

Banwart S. A., Berg A. and Beerling D. J. (2009) Process-based modeling of silicate mineral weathering responses to increasing atmospheric $\mathrm{CO}_{2}$ and climate change. Global Biogeochem. Cycles 23, GB4013.

Balagizi C. M., Darchambeau F., Bouillon S., Yalire M. M., Lambert T. and Borges A. V. (2015) River geochemistry, chemical weathering, and atmospheric $\mathrm{CO}_{2}$ consumption rates in the Virunga Volcanic Province (East Africa). Geochem. Geophys. Geosyst. 16, 2637-2660.

Beerling D. J., Taylor L. L., Bradshaw C. D. C., Lunt D. J., Valdes P. J., Banwart S. A., Pagani M. and Leake J. R. (2012) Ecosystem $\mathrm{CO}_{2}$ starvation and terrestrial 
silicate weathering: mechanisms and global-scale quantification during the late Miocene. J. Ecol. 100, 31-41.

Bethke C. M. and Yeakel S. (2015) The Geochemist's Workbench 10.0: Reference Manual. Aqueous Solutions, LLC, Champaign, IL, pp. 1-446.

Berner R. A. (1991) A model for atmospheric $\mathrm{CO}_{2}$ over Phanero- zoic time. Am. J. Sci. $291,339-376$.

Berner R. A. (2006a) GEOCARBSULF: a combined model for Phanerozoic atmospheric $\mathrm{O}_{2}$ and $\mathrm{CO}_{2}$. Geochim. Cosmochim. Acta 70, 5653-5664.

Berner R. A. (2006b) Inclusion of the weathering of volcanic rocks in the GEOCARBSULF model. Am. J. Sci. 306, 295-302.

Berner R. A. (2008) Addendum to "Inclusion of the Weathering of Volcanic Rocks in the GEOCARBSULF Model” (R.A. Berner, 2006, V. 306, p. 295-302). Am. J. Sci. 308, 100-103.

Berner R. A. and Caldeira K. (1997) The need for mass balance and feedback in the geochemical carbon cycle. Geology 25, 955.

Berner R. A. and Kothavala Z. (2001) Geocarb III: a revised model of atmospheric $\mathrm{CO}_{2}$ over Phanerozoic time. Am. J. Sci. 301, 182-204.

Berner R. A., Lasaga A. C. and Garrels R. M. (1983) The carbonate-silicate geochemical cycle and its effect on atmo- spheric carbon dioxide over the past 100 million years. Am. J. Sci. 283, 641-683.

Blanc P., Lassin A., Piantone P., Azaroual M., Jacquemet N., Fabbri A. and Gaucher E. C. (2012) Thermoddem: a geochemical database focused on low temperature water/rock interactions and waste materials. Appl. Geochem. 27, 2107-2116. 
Blum J. D., Gazis C. A., Jacobson A. D. and Chamberlain C. P. (1998) Carbonate versus silicate weathering in the Raikhot watershed within the High Himalayan Crystalline Series. Geology 26, 411-414.

Bluth G. J. S. and Kump L. R. (1994) Lithologic and climatologic controls of river chemistry. Geochim. Cosmochim. Acta 58, 2341-2359.

Bluth G. J. S. and Kump L. R. (1991) Phanerozoic paleogeology. Am. J. Sci. 291, 284308.

Bolle M. P. and Adatte T. (2001) Palaeocene-early Eocene climatic evolution in the Tethyan realm: clay mineral evidence. Clay Miner. 36, 249-261.

Bouchez J. and Gaillardet J. (2014) How accurate are rivers as gauges of chemical denudation of the Earth surface? Geology 42, 171-174.

Bouchez J., Gaillardet J., Lupker M., Louvat P., France-Lanord C., Maurice L., Armijos E. and Moquet J. S. (2012) Flood- plains of large rivers: weathering reactors or simple silos? Chem. Geol. 332-333, 166-184.

Bouchez J., Gaillardet J. and Blanckenburg von F. (2014) Weathering intensity in lowland river basins: from the Andes to the amazon mouth. Proc. Earth Planet. Sci. 10, 280-286.

Bowen G. J., Beerling D. J., Koch P. L., Zachos J. C. and Quattlebaum T. (2004) A humid climate state during the Palaeocene/Eocene thermal maximum. Nature 432, 495-499.

Caldeira K. (1992) Enhanced Cenozoic chemical weathering and the subduction of pelagic carbonate. Nature $357,578-581$. 
Caldeira K. (1995) Long-term control of atmospheric carbon dioxide: low-temperature seafloor alteration or terrestrial silicate-rock weathering? Am. J. Sci. 295, 10771114.

Caldeira K. and Kasting J. F. (1992) The life span of the biosphere revisited. Nature 360, $721-723$.

Carroll S. A. and Knauss K. G. (2005) Dependence of labradorite dissolution kinetics on $\mathrm{CO}_{2}(\mathrm{aq}), \mathrm{Al}(\mathrm{aq})$, and temperature. Chem. Geol. 217, 213-225.

Caves J. K., Sjostrom D. J., Mix H. T., Winnick M. J. and Chamberlain C. P. (2014) Aridification of Central Asia and uplift of the Altai and Hangay mountains, Mongolia: stable isotope evidence. Am. J. Sci. 314, 1171-1201.

Caves J. K., Winnick M. J., Graham S. A., Sjostrom D. J., Mulch A. and Chamberlain C. P. (2015) Role of the westerlies in Central Asia climate over the Cenozoic. Earth Planet. Sci. Lett. 428, 33-43.

Caves J. K., Jost A. B., Lau K. V. and Maher K. (2016) Cenozoic carbon cycle imbalances and a variable weathering feedback. Earth Planet. Sci. Lett. 450, 152163.

Chamberlain C. P., Waldbauer J. R. and Jacobson A. D. (2005) Strontium, hydrothermal systems and steady-state chemical weathering in active mountain belts. Earth Planet. Sci. Lett. 238, 351-366.

Chanat J. G., Rice K. C. and Hornberger G. M. (2002) Consistency of patterns in concentration-discharge plots. Water Resour. Res. 38, 1147.

Chorover J. and Sposito G. (1995) Surface charge characteristics of kaolinitic tropical soils. Geochim. Cosmochim. Acta 59, 875-884. 
Chorover J., Kretzschmar R., Garcia-Pichel F. and Sparks D. L. (2007) Soil biogeochemical processes within the critical zone. Elements 3, 321-326.

Clow D. W. and Mast M. A. (2010) Mechanisms for chemostatic behavior in catchments: implications for $\mathrm{CO}_{2}$ consumption by mineral weathering. Chem. Geol. 269, 4051.

Cox G. M., Halverson G. P., Stevenson R. K., Vokaty M., Poirier A., Kunzmann M., Li Z. X., Denyszyn S. W., Strauss J. V. and Macdonald F. A. (2016) Continental flood basalt weathering as a trigger for Neoproterozoic Snowball Earth. Earth Planet. Sci. Lett. 446, 89-99.

Dai A. and Trenberth K. E. (2002) Estimates of freshwater discharge from continents: latitudinal and seasonal variations. J. Hydrometeorol. 3, 660-687.

DeCelles P. G., Quade J., Kapp P., Fan M., Dettman D. L. and Ding L. (2007) High and dry in central Tibet during the Late Oligocene. Earth Planet. Sci. Lett. 253, 389401.

Dessert C., Dupré B., François L. M., Schott J., Gaillardet J., Chakrapani G. and Bajpai S. (2001) Erosion of Deccan Traps determined by river geochemistry: impact on the global climate and the ${ }^{87} \mathrm{Sr} /{ }^{86} \mathrm{Sr}$ ratio of seawater. Earth Planet. Sci. Lett. 188, 459-474.

Dessert C., Dupré B., Gaillardet J., François L. M. and Allègre C. J. (2003) Basalt weathering laws and the impact of basalt weathering on the global carbon cycle. Chem. Geol. 202, 257-273.

Dessert C., Gaillardet J., Dupré B., Schott J. and Pokrovsky O. S. (2009) Fluxes of highversus low-temperature water-rock interactions in aerial volcanic areas: example 
from the Kam- chatka Peninsula, Russia. Geochim. Cosmochim. Acta 73, 148169.

Dessert C., Lajeunesse E., Lloret E., Clergue C., Crispi O., Gorge C. and Quidelleur X. (2015) Controls on chemical weathering on a mountainous volcanic tropical island: Guadeloupe (French West Indies). Geochim. Cosmochim. Acta 171, 216237.

Dixon J. L. and von Blanckenburg F. (2012) Soils as pacemakers and limiters of global silicate weathering. C.R. Geosci. 344, 597- 609.

Donnadieu Y., Goddéris Y., Ramstein G., Nédélec A. and Meert J. (2004) A “'snowball Earth" climate triggered by continental break-up through changes in runoff. Nature 428, 303-306.

Drever J. I. and Zobrist J. (1992) Chemical weathering of silicate rocks as a function of elevation in the southern Swiss Alps. Geochim. Cosmochim. Acta 56, 3209-3216.

Dupré B., Dessert C., Oliva P., Goddéris Y., Viers J., François L., Millot R. and Gaillardet J. (2003) Rivers, chemical weathering and Earth's climate. C.R. Geosci. 335, 1141-1160.

Dürr H. H., Meybeck M., Hartmann J., Laruelle G. G. and Roubeix V. (2011) Global spatial distribution of natural riverine silica inputs to the coastal zone. Biogeosciences 8, 597-620.

Eberl D. D. (1984) Clay mineral formation and transformation in rocks and soil. Philos. Trans. R. Soc. Lond. A 311, 241-257. 
Eiriksdottir E. S., Louvat P., Gislason S. R., Óskarsson N. and Hardardóttir J. (2008) Temporal variation of chemical and mechanical weathering in NE Iceland: evaluation of a steady- state model of erosion. Earth Planet. Sci. Lett. 272, 78-88.

Eiriksdottir E. S., Gíslason S. R. and Oelkers E. H. (2013) Does temperature or runoff control the feedback between chemical denudation and climate? Insights from NE Iceland. Geochim. Cosmochim. Acta 107, 65-81.

Eiriksdottir E. S., Gislason S. R. and Oelkers E. H. (2015) Direct evidence of the feedback between climate and nutrient, major, and trace element transport to the oceans. Geochim. Cosmochim. Acta 166, 249-266.

Foreman B. Z., Heller P. L. and Clementz M. T. (2012) Fluvial response to abrupt global warming at the Palaeocene/Eocene boundary. Nature 491, 92-95.

Froelich F. and Misra S. (2014) Was the late Paleocene-early Eocene hot because Earth was flat? An ocean lithium isotope view of mountain building, continental weathering, carbon dioxide, and Earth's Cenozoic climate. Oceanography 27, $36-$ 49.

Gaillardet J., Dupré B., Louvat P. and Allegre C. J. (1999) Global silicate weathering and $\mathrm{CO}_{2}$ consumption rates deduced from the chemistry of large rivers. Chem. Geol. $159,3-30$.

Gaillardet J., Louvat P. and Lajeunesse E. (2011a) Rivers from volcanic island arcs: the subduction weathering factory. Appl. Geochem. 26, S350-S353.

Gaillardet J., Rad S., Rivé K., Louvat P., Gorge C., Allègre C. J. and Lajeunesse E. (2011b) Orography-driven chemical denuda- tion in the Lesser Antilles: evidence 
for a new feed-back mechanism stabilizing atmospheric $\mathrm{CO}_{2}$. Am. J. Sci. 311, $851-894$.

Garzione C. N., Hoke G. D., Libarkin J. C., Withers S., MacFadden B., Eiler J., Ghosh P. and Mulch A. (2008) Rise of the Andes. Science 320, 1304-1307.

Gibbs M. T. and Kump L. R. (1994) Global chemical erosion during the Last Glacial Maximum and the present: sensitivity to changes in lithology and hydrology. Paleoceanography 9, 529-543.

Gibbs M. T., Bluth G. J. S., Fawcett P. J. and Kump L. R. (1999) Global chemical erosion over the last $250 \mathrm{MY}$ : variations due to changes in paleogeography, paleoclimate, and paleogeology. Am. J. Sci. 299, 611-651.

Gíslason S. R. and Eugster H. P. (1987) Meteoric water-basalt interactions. II: a field study in N.E. Iceland. Geochim. Cosmochim. Acta 51, 2841-2855.

Gíslason S. R. and Oelkers E. H. (2003) Mechanism, rates, and consequences of basaltic glass dissolution: II. An experimental study of the dissolution rates of basaltic glass as a function of $\mathrm{pH}$ and temperature. Geochim. Cosmochim. Acta 67, 38173832.

Gíslason S. D. S. R., Arnórsson S. and Ármannsson H. (1996) Chemical weathering of basalt in Southwest Iceland: effects of runoff, age of rocks and vegetative/glacial cover. Am. J. Sci. 296, 837-907.

Gíslason S. R., Oelkers E. H., Eiriksdottir E. S., Kardjilov M. I., Gisladottir G., Sigfusson B., Snorrason A., Elefsen S., Hardar- dottir J., Torssander P. and Oskarsson N. (2009) Direct evidence of the feedback between climate and weathering. Earth Planet. Sci. Lett. 277, 213-222. 
Gleeson T., Smith L., Moosdorf N., Hartmann J., Dürr H. H., Manning A. H., van Beek L. P. H. and Jellinek A. M. (2011) Mapping permeability over the surface of the Earth. Geophys. Res. Lett. 38, L02401.

Goddéris Y., Donnadieu Y., Tombozafy M. and Dessert C. (2008) Shield effect on continental weathering: implication for climatic evolution of the Earth at the geological timescale. Geoderma 145, 439-448.

Godsey S. E., Kirchner J. W. and Clow D. W. (2009) Concentration-discharge relationships reflect chemostatic characteristics of US catchments. Hydrol. Process 23, 1844-1864.

Goldsmith S. T., Harmon R. S., Lyons W. B., Harmon B. A., Ogden F. L. and Gardner C. B. (2015) Evaluation of controls on silicate weathering in tropical mountainous rivers: insights from the Isthmus of Panama. Geology 43, 563-566.

Goll D. S., Moosdorf N., Hartmann J. and Brovkin V. (2014) Climate-driven changes in chemical weathering and associated phosphorus release since 1850: implications for the land carbon balance. Geophys. Res. Lett. 41, 3553-3558.

Grothendieck G. (2013) nls2: non-linear regression with brute force. R package version 0.2 .

Hartmann J. (2009) Bicarbonate-fluxes and $\mathrm{CO}_{2}$-consumption by chemical weathering on the Japanese Archipelago — application of a multi-lithological model framework. Chem. Geol. 265, 237-271.

Hartmann J. and Moosdorf N. (2011) Chemical weathering rates of silicate-dominated lithological classes and associated liber- ation rates of phosphorus on the Japanese Archipelago - implications for global scale analysis. Chem. Geol. 287, 125- 157. 
Hartmann J. and Moosdorf N. (2012) The new global lithological map database GLiM: a representation of rock properties at the Earth surface. Geochem. Geophys. Geosyst. 13.

Hartmann J., Jansen N., Kempe S. and Dürr H. H. (2007) Geochemistry of the river Rhine and the upper Danube: recent trends and lithological influences on baselines. J. Environ. Sci. Sustain. Soc. 1, 39-46.

Hartmann J., Jansen N., Dürr H. H., Kempe S. and Köhler P. (2009) Global CO ${ }_{2-}$ consumption by chemical weathering: what is the contribution of highly active weathering regions? Global Planet. Change 69, 185-194.

Hartmann J., Jansen N., Dürr H. H., Harashima A., Okubo K. and Kempe S. (2010) Predicting riverine dissolved silica fluxes to coastal zones from a hyperactive region and analysis of their first-order controls. Int. J. Earth Sci. 99, 207-230.

Hartmann J., Levy J. and Kempe S. (2011) Increasing dissolved silica trends in the Rhine River: an effect of recovery from high P loads? Limnology 12, 63-73.

Hartmann J., Moosdorf N., Lauerwald R., Hinderer M. and West A. J. (2014a) Global chemical weathering and associated P- release - the role of lithology, temperature and soil properties. Chem. Geol. 363, 145-163.

Hartmann J., Lauerwald R. and Moosdorf N. (2014b) A brief overview of the GLObal RIver chemistry database, GLORICH. Proc. Earth Planet. Sci. 10, 23-27.

Hilley G. E., Chamberlain C. P., Moon S., Porder S. and Willett S. D. (2010) Competition between erosion and reaction kinetics in controlling silicateweathering rates. Earth Planet. Sci. Lett. 293, 191-199. 
Horton T. W., Chamberlain C. P., Fantle M. and Blum J. D. (1999) Chemical weathering and lithologic controls of water chemistry in a high-elevation river system: Clark's Fork of the Yellowstone river, Wyoming and Montana. Water Resour. Res. 35, 1643-1655.

Hren M. T., Hilley G. E. and Chamberlain C. P. (2007) The relationship between tectonic uplift and chemical weathering rates in the Washington Cascades: field measurements and model predictions. Am. J. Sci. 307, 1041-1063.

Jacobson A. D., Blum J. D., Chamberlain C. P., Poage M. A. and Sloan V. F. (2002) $\mathrm{Ca} / \mathrm{Sr}$ and $\mathrm{Sr}$ isotope systematics of a Himalayan glacial chronosequence: carbonate versus silicate weathering rates as a function of landscape surface age. Geochim. Cosmochim. Acta 66, 13-27.

Jacobson A. D., Blum J. D., Chamberlain C. P., Craw D. and Koons P. O. (2003) Climatic and tectonic controls on chemical weathering in the New Zealand Southern Alps. Geochim. Cosmochim. Acta 67, 29-46.

Jacobson A. D., Grace Andrews. M., Lehn G. O. and Holmden C. (2015) Silicate versus carbonate weathering in Iceland: new insights from Ca isotopes. Earth Planet. Sci. Lett. 416, 132-142.

Jagoutz O., Macdonald F. A. and Royden L. (2016) Low-latitude arc-continent collision as a driver for global cooling. Proc. Natl. Acad. Sci. U.S.A. 113, 4935-4940.

Jansen N., Hartmann J., Lauerwald R., Dürr H. H., Kempe S., Loos S. and Middelkoop H. (2010) Dissolved silica mobiliza- tion in the conterminous USA. Chem. Geol. 270, 90-109. 
Johnson T. M. and DePaolo D. J. (1994) Interpretation of isotopic data in groundwaterrock systems: model development and application to Sr isotope data from Yucca Mountain. Water Resour. Res. 30, 1571-1587.

Kasting J. F. (1993) Earth's early atmosphere. Science 259, 920- 926.

Kent D. V. and Muttoni G. (2008) Equatorial convergence of India and early Cenozoic climate trends. Proc. Natl. Acad. Sci. U.S.A. 105, 16065-16070.

Kent D. V. and Muttoni G. (2013) Modulation of Late Cretaceous and Cenozoic climate by variable drawdown of atmospheric $\mathrm{pCO} 2$ from weathering of basaltic provinces on continents drifting through the equatorial humid belt. Clim. Past 9, $525-546$.

Kim H., Bishop J. K. B., Dietrich W. E. and Fung I. Y. (2014) Process dominance shift in solute chemistry as revealed by long- term high-frequency water chemistry observations of ground- water flowing through weathered argillite underlying a steep forested hillslope. Geochim. Cosmochim. Acta 140, 1-19.

Kirchner J. W. and Neal C. (2013) Universal fractal scaling in stream chemistry and its implications for solute transport and water quality trend detection. Proc. Natl. Acad. Sci. U.S.A. 110, 12213-12218.

Kirchner J., Feng X. and Neal C. (2000) Fractal stream chemistry and its implications for contaminant transport in catchments. Nature 403, 524-527.

Kirchner J. W., Finkel R. C., Riebe C. S., Granger D. E., Clayton J. L., King J. G. and Megahan W. F. (2001) Mountain erosion over 10 yr, 10 k.y., and 10 m.y. time scales. Geology 29, 591- 594. 
Kollet S. J. and Maxwell R. M. (2008) Demonstrating fractal scaling of baseflow residence time distributions using a fully- coupled groundwater and land surface model. Geophys. Res. Lett. 35, L07402.

Kump L. R. and Arthur M. A. (1997) Global chemical erosion during the Cenozoic: weatherability balances the budgets. In Tectonic Uplift and Climate Change. Springer US, Boston, MA, pp. 399-426.

Kump L. R., Brantley S. L. and Arthur M. A. (2000) Chemical weathering, atmospheric CO2, and climate. Annu. Rev. Earth Planet. Sci. 28, 611-667.

Lauerwald R., Hartmann J., Moosdorf N., Dürr H. H. and Kempe S. (2013) Retention of dissolved silica within the fluvial system of the conterminous USA. Biogeochemistry 112, 637-659.

Lauerwald R., Laruelle G. G., Hartmann J., Ciais P. and Regnier P. A. (2015) Spatial patterns in $\mathrm{CO} 2$ evasion from the global river network. Global Biogeochem. Cycles.

Le Hir G., Donnadieu Y., Goddéris Y., Pierrehumbert R. T., Halverson G. P., Macouin M., Nédélec A. and Ramstein G. (2009) The snowball Earth aftermath: exploring the limits of continental weathering processes. Earth Planet. Sci. Lett. 277, 453463.

Lee C.-T. A., Thurner S., Paterson S. and Cao W. (2015) The rise and fall of continental arcs: interplays between magmatism, uplift, weathering, and climate. Earth Planet. Sci. Lett. 425, 105-119. 
Lefebvre V., Donnadieu Y., Goddéris Y., Fluteau F. and Hubert- Théou L. (2013) Was the Antarctic glaciation delayed by a high degassing rate during the early Cenozoic? Earth Planet. Sci. Lett. 371-372, 203-211.

Li D. D., Jacobson A. D. and McInerney D. J. (2014) A reactive- transport model for examining tectonic and climatic controls on chemical weathering and atmospheric CO2 consumption in granitic regolith. Chem. Geol. 365, 30-42.

Li G. and Long X. (2014) Weathering of Chinese basaltic fields. Proc. Earth Planet. Sci. $10,69-72$.

Li G. and Elderfield H. (2013) Evolution of carbon cycle over the past 100 million years. Geochim. Cosmochim. Acta 103, 11-25.

Li G., Hartmann J., Derry L. A., West A. J., You C.-F., Long X., Zhan T., Li L., Li G., Qiu W., Li T., Liu L., Chen Y., Ji J., Zhao L. and Chen J. (2016) Temperature dependence of basalt weathering. Earth Planet. Sci. Lett. 443, 59-69.

Liu X.-M., Wanner C., Rudnick R. L. and McDonough W. F. (2015) Processes controlling $\delta^{7} \mathrm{Li}$ in rivers illuminated by study of streams and groundwaters draining basalts. Earth Planet. Sci. Lett. 409, 212-224.

Louvat P. and Allègre C. J. (1997) Present denudation rates on the island of Réunion determined by river geochemistry: basalt weathering and mass budget between chemical and mechanical erosions. Geochim. Cosmochim. Acta 61, 3645-3669.

Ludwig W., Amiotte-Suchet P. and Probst J.-L. (1999) Enhanced chemical weathering of rocks during the last glacial maximum: a sink for atmospheric $\mathrm{CO}_{2}$ ? Chem. Geol. $159,147-161$. 
Lupker M., France-Lanord C., Galy V., Lavé J., Gaillardet J., Gajurel A. P., Guilmette C., Rahman M., Singh S. K. and Sinha R. (2012) Predominant floodplain over mountain weath- ering of Himalayan sediments (Ganga basin). Geochim. Cosmochim. Acta 84, 410-432.

Maavara T., Du rrr H. H. and Van Cappellen P. (2014) Worldwide retention of nutrient silicon by river damming: from sparse data set to global estimate. Global Biogeochem. Cycles 28, 842-855.

Maher K. (2010) The dependence of chemical weathering rates on fluid residence time. Earth Planet. Sci. Lett. 294, 101-110.

Maher K. (2011) The role of fluid residence time and topographic scales in determining chemical fluxes from landscapes. Earth Planet. Sci. Lett. 312, 48-58.

Maher K. and Chamberlain C. P. (2014) Hydrologic regulation of chemical weathering and the geologic. Science 343, 1502-1504.

Maher K. and Druhan J. (2014) Relationships between the transit time of water and the fluxes of weathered elements through the critical zone. Proc. Earth Planet. Sci. 10, $16-22$.

Maher K., Steefel C. I., White A. F. and Stonestrom D. A. (2009) The role of reaction affinity and secondary minerals in regulating chemical weathering rates at the Santa Cruz Soil Chronosequence, California. Geochim. Cosmochim. Acta 73, 2804-2831.

Małoszewski P. and Zuber A. (1982) Determining the turnover time of groundwater systems with the aid of environmental tracers. J. Hydrol. 57, 207-231. 
Manabe S., Wetherald R. T., Milly P. C. D., Delworth T. L. and Stouffer R. J. (2004) Century-scale change in water availability: CO2-quadrupling experiment. Clim. Change 64, 59-76.

Marty N. C. M., Bildstein O., Blanc P., Claret F., Cochepin B., Gaucher E. C., Jacques D., Lartigue J. E., Liu S., Mayer K. U., Meeussen J. C. L., Munier I., Pointeau I., Su D. and Steefel C. I. (2015) Benchmarks for multicomponent reactive transport across a cement/clay interface. Comput. Geosci. 19, 635-653.

Maxwell R. M., Condon L. E., Kollet S. J., Maher K., Haggerty R. and Forrester M. M. (2016) The imprint of climate and geology on the residence times of groundwater. Geophys. Res. Lett. 43, 701-708.

McGuire K. J. and McDonnell J. J. (2006) A review and evaluation of catchment transit time modeling. J. Hydrol. 330, 543-563.

McGuire K. J., McDonnell J. J., Weiler M., Kendall C., McGlynn B. L., Welker J. M. and Seibert J. (2005) The role of topography on catchment-scale water residence time. Water Resour. Res. 41.

Mills B., Daines S. J. and Lenton T. M. (2014a) Changing tectonic controls on the longterm carbon cycle from Mesozoic to present. Geochem. Geophys. Geosyst. 15, $4866-4884$.

Mills B., Lenton T. M. and Watson A. J. (2014b) Proterozoic oxygen rise linked to shifting balance between seafloor and terrestrial weathering. Proc. Natl. Acad. Sci. U.S.A. 111, 9073- 9078. 
Mills B., Watson A. J., Goldblatt C., Boyle R. and Lenton T. M. (2011) Timing of Neoproterozoic glaciations linked to trans- port-limited global weathering. Nat. Geosci. 4, 861-864.

Minasny B., Finke P., Stockmann U., Vanwalleghem T. and McBratney A. B. (2015) Resolving the integral connection between pedogenesis and landscape evolution. Earth-Sci. Rev. 150, 102-120.

Mix H. T., Mulch A., Kent-Corson M. L. and Chamberlain C. P. (2011) Cenozoic migration of topography in the North American Cordillera. Geology 39, 87-90.

Mix H. T., Ibarra D. E., Mulch A., Graham S. A. and Chamberlain C. P. (2016) A hot and high Eocene Sierra Nevada. Bull. Geol. Soc. Am. 128, 531-542.

Molnar P. and Cronin T. W. (2015) Growth of the Maritime Continent and its possible contribution to recurring Ice Ages. Paleoceanography 30, 196-225.

Montgomery D. R., Balco G. and Willett S. D. (2001) Climate, tectonics, and the morphology of the Andes. Geology 29, 579- 582.

Moon S., Huh Y., Qin J. and van Pho N. (2007) Chemical weathering in the Hong (Red) River basin: rates of silicate weathering and their controlling factors. Geochim. Cosmochim. Acta 71, 1411-1430.

Moon S., Huh Y. and Zaitsev A. (2009) Hydrochemistry of the Amur River: weathering in a Northern Temperate Basin. Aquat. Geochem. 15, 497-527.

Moon S., Chamberlain C. P., Blisniuk K., Levine N., Rood D. H. and Hilley G. E. (2011) Climatic control of denudation in the deglaciated landscape of the Washington Cascades. Nat. Geosci. 4, 469-473. 
Moon S., Chamberlain C. P. and Hilley G. E. (2014) New estimates of silicate weathering rates and their uncertainties in global rivers. Geochim. Cosmochim. Acta 134, $257-274$.

Moore J., Jacobson A. D., Holmden C. and Craw D. (2013) Tracking the relationship between mountain uplift, silicate weathering, and long-term $\mathrm{CO}_{2}$ consumption with Ca isotopes: Southern Alps, New Zealand. Chem. Geol. 341, 110-127.

Moosdorf N., Hartmann J., Lauerwald R., Hagedorn B. and Kempe S. (2011) Atmospheric $\mathrm{CO}_{2}$ consumption by chemical weathering in North America. Geochim. Cosmochim. Acta 75, 7829-7854.

Moquet J.-S., Guyot J.-L., Crave A., Viers J., Filizola N., Martinez J.-M., Oliveira T. C., Sa' nchez L. S. H., Lagane C., Casimiro W. S. L., Noriega L. and Pombosa R. (2015) Amazon River dissolved load: temporal dynamics and annual budget from the Andes to the ocean. Environ. Sci. Pollut. Res., 1-25.

Mulch A. and Chamberlain C. P. (2006) Earth science: the rise and growth of Tibet. Nature 439, 670-671.

Munhoven G. (2002) Glacial-Interglacial changes of continental weathering: estimates of the related $\mathrm{CO} 2$ and $\mathrm{HCO} 3$ flux variations and their uncertainties. Global Planet. Change 33, 155-176.

Navarre-Sitchler A. and Brantley S. (2007) Basalt weathering across scales. Earth Planet. Sci. Lett. 261, 321-334.

Navarre-Sitchler A. and Thyne G. (2007) Effects of carbon dioxide on mineral weathering rates at earth surface conditions. Chem. Geol. 243, 53-63. 
Navarre-Sitchler A., Steefel C. I., Yang L., Tomutsa L. and Brantley S. L. (2009) Evolution of porosity and diffusivity associated with chemical weathering of a basalt clast. J. Geophys. Res. 114, F02016.

Navarre-Sitchler A., Steefel C. I., Sak P. B. and Brantley S. L. (2011) A reactivetransport model for weathering rind forma- tion on basalt. Geochim. Cosmochim. Acta $75,7644-7667$.

Navarre-Sitchler A. K., Cole D. R., Rother G., Jin L., Buss H. L. and Brantley S. L. (2013) Porosity and surface area evolution during weathering of two igneous rocks. Geochim. Cosmochim. Acta 109, 400-413.

Navarre-Sitchler A., Brantley S. L. and Rother G. (2015) How porosity increases during incipient weathering of crystalline silicate rocks. Rev. Mineral. Geochem. 80, $331-354$.

Norton K. P. and von Blanckenburg F. (2010) Silicate weathering of soil-mantled slopes in an active Alpine landscape. Geochim. Cosmochim. Acta 74, 5243-5258.

Oelkers E.H. and Gíslason S.R. (2001)Themechanism,ratesand consequences of basaltic glass dissolution: I. An experimental study of the dissolution rates of basaltic glass as a function of aqueous $\mathrm{Al}, \mathrm{Si}$ and oxalic acid concentration at $25 \mathrm{C}$ and $\mathrm{pH}$ $=3$ and 11. Geochim. Cosmochim. Acta 65, 3671-3681.

Otto-Bliesner B. L. (1995) Continental drift, runoff, and weathering feedbacks: implications from climate model experiments. J. Geophys. Res. 100, 1153711548.

Pagani M., Pedentchouk N., Huber M., Sluijs A., Schouten S., Brinkhuis H., Damsté J.S.S. and Dickens G.R. Expedition 302 Scientists (2006) Arctic hydrology during 
global warming at the Palaeocene/Eocene thermal maximum. Nature 442, 671675.

Pagani M., Caldeira K., Berner R. and Beerling D. J. (2009) The role of terrestrial plants in limiting atmospheric $\mathrm{CO}_{2}$ decline over the past 24 million years. Nature 460 , $85-88$.

Parry S. A., Hodson M. E., Kemp S. J. and Oelkers E. H. (2015) The surface area and reactivity of granitic soils: I. Dissolution rates of primary minerals as a function of depth and age deduced from field observations. Geoderma 237-238, 21-35.

Pierrehumbert R. T. (2002) The hydrologic cycle in deep-time climate problems. Nature 419, 191-198.

Pokrovsky O. S., Schott J., Kudryavtzev D. I. and Dupré B. (2005) Basalt weathering in Central Siberia under permafrost condi- tions. Geochim. Cosmochim. Acta 69, $5659-5680$.

Porder S., Vitousek P. M., Chadwick O. A., Chamberlain C. P. and Hilley G. E. (2007) Uplift, erosion, and phosphorus limitation in terrestrial ecosystems. Ecosystems $10,159-171$.

Rad S. D., Allegre C. J. and Louvat P. (2007) Hidden erosion on volcanic islands. Earth Planet. Sci. Lett. 262, 109-124.

Rempe D. M. and Dietrich W. E. (2014) A bottom-up control on fresh-bedrock topography under landscapes. Proc. Natl. Acad. Sci. U.S.A. 111, 6576-6581.

Rowley D. B. and Currie B. S. (2006) Palaeo-altimetry of the late Eocene to Miocene Lunpola basin, central Tibet. Nature 439, 677-681. 
Royer D. L., Donnadieu Y., Park J., Kowalczyk J. and Goddéris Y. (2014) Error analysis of $\mathrm{CO}_{2}$ and $\mathrm{O}_{2}$ estimates from the long- term geochemical model GEOCARBSULF. Am. J. Sci. 314, 1259-1283.

Ryu J.-S., Jacobson A. D., Holmden C., Lundstrom C. and Zhang Z. (2011) The major ion, $\delta^{44} /{ }^{40} \mathrm{Ca}, \delta^{44} /{ }^{42} \mathrm{Ca}$, and $\delta^{26 / 24} \mathrm{Mg}$ geochemistry of granite weathering at $\mathrm{pH}=1$ and $\mathrm{T}=25 \mathrm{C}$ : power-law processes and the relative reactivity of minerals. Geochim. Cosmochim. Acta 75, 6004-6026.

Sagan C. and Mullen G. (1972) Earth and Mars: evolution of atmospheres and surface temperatures. Science 177, 52-56.

Sak P. B., Navarre-Sitchler A. K., Miller C. E., Daniel C. C., Gaillardet J., Buss H. L., Lebedeva M. I. and Brantley S. L. (2010) Controls on rind thickness on basaltic andesite clasts weathering in Guadeloupe. Chem. Geol. 276, 129-143.

Scher H., Margolin G., Metzler R., Klafter J. and Berkowitz B. (2002) The dynamical foundation of fractal stream chemistry: the origin of extremely long retention times. Geophys. Res. Lett. 29, 1061.

Schopka H. H. and Derry L. A. (2012) Chemical weathering fluxes from volcanic islands and the importance of groundwater: the Hawaiian example. Earth Planet. Sci. Lett. 339-340, 67-78.

Schopka H. H., Derry L. A. and Arcilla C. A. (2011) Chemical weathering, river geochemistry and atmospheric carbon fluxes from volcanic and ultramafic regions on Luzon Island, the Philippines. Geochim. Cosmochim. Acta 75, 978-1002. 
Schott J., Pokrovsky O. S. and Oelkers E. H. (2009) The link between mineral dissolution/precipitation kinetics and solution chemistry. Rev. Mineral. Geochem. $70,207-258$.

Schwartzman D. W. and Volk T. (1989) Biotic enhancement of weathering and the habitability of Earth. Nature 340, 457-460. Siirila E. R. and Maxwell R. M. (2012) Evaluating effective reaction rates of kinetically driven solutes in largescale, statistically anisotropic media: human health risk implications. Water Resour. Res. 48, W04527.

St. Clair J., Moon S., Holbrook W. S., Perron J. T., Riebe C. S., Martel S. J., Carr B., Harman C., Singha K. and Richter D. D. (2015) Geophysical imaging reveals topographic stress control of bedrock weathering. Science 350, 534-538.

Steefel C. I. and Van Cappellen P. (1990) A new kinetic approach to modeling waterrock interaction: the role of nucleation, precursors, and Ostwald ripening. Geochim. Cosmochim. Acta 54, 2657-2677.

Steefel C. I. and Maher K. (2009) Fluid-rock interaction: a reactive transport approach. Rev. Mineral. Geochem. 70, 485-532.

Stefánsson A. and Gíslason S. R. (2001) Chemical weathering of basalts, southwest Iceland: effect of rock crystallinity and secondary minerals on chemical fluxes to the ocean. Am. J. Sci. 301, 513-556.

Stefánsson A., Gíslason S. R. and Arnórsson S. (2001) Dissolution of primary minerals in natural waters II. Mineral saturation state. Chem. Geol. 172, 251-276. 
Sverdrup H. and Warfvinge P. (1988) Weathering of primary silicate minerals in the natural soil environment in relation to a chemical weathering model. Water Air Soil Pollut. 38, 387-408.

Taylor A. and Blum J. D. (1995) Relation between soil age and silicate weathering rates determined from the chemical evolution of a glacial chronosequence. Geology 23, 979-982.

Tipple B. J., Pagani M., Krishnan S., Dirghangi S. S., Galeotti S., Agnini C., Giusberti L. and Rio D. (2011) Coupled high- resolution marine and terrestrial records of carbon and hydro- logic cycles variations during the Paleocene-Eocene Thermal Maximum (PETM). Earth Planet. Sci. Lett. 311, 82-92.

Torres M. A., West A. J. and Clark K. E. (2015) Geomorphic regime modulates hydrologic control of chemical weathering in the Andes-Amazon. Geochim. Cosmochim. Acta 166, 105-128.

Uchikawa J. and Zeebe R. E. (2008) Influence of terrestrial weathering on ocean acidification and the next glacial inception. Geophys. Res. Lett. 35, L23608.

Urey H. C. (1952) On the early chemical history of the earth and the origin of life. Proc. Natl. Acad. Sci. U.S.A. 38, 351-363.

Velbel M. A. (1993) Constancy of silicate-mineral weathering-rate ratios between natural and experimental weathering: implica- tions for hydrologic control of differences in absolute rates. Chem. Geol. 105, 89-99.

Volk T. (1987) Feedbacks between weathering and atmospheric CO2 over the last 100 million years. Am. J. Sci. 287, 763-779. 
von Blanckenburg F. (2005) The control mechanisms of erosion and weathering at basin scale from cosmogenic nuclides in river sediment. Earth Planet. Sci. Lett. 237, $462-479$.

von Blanckenburg F., Hewawasam T. and Kubik P. W. (2004) Cosmogenic nuclide evidence for low weathering and denuda- tion in the wet, tropical highlands of Sri Lanka. J. Geophys. Res. 109, F03008.

von Blanckenburg F., Bouchez J., Ibarra D. E. and Maher K. (2015) Stable runoff and weathering fluxes into the oceans over Quaternary climate cycles. Nat. Geosci. 8, $538-542$.

Waldbauer J. R. and Chamberlain C. P. (2005) Influence of uplift, weathering, and base cation supply on past and future $\mathrm{CO}_{2}$ levels. In A History of Atmospheric $\mathrm{CO}_{2}$ and Its Effects on Plants, Animals, and Ecosystems Ecological Studies. Springer New York, New York, pp. 166-184.

Walker J. C. G., Hays P. B. and Kasting J. F. (1981) A negative feedback mechanism for the long-term stabilization of Earth's surface temperature. J. Geophys. Res. 86, 9776-9782.

Wallin M. B., Öquist M. G., Buffam I., Billett M. F., Nisell J. and Bishop K. H. (2011) Spatiotemporal variability of the gas transfer coefficient $\left(\mathrm{KCO}_{2}\right)$ in boreal streams: implications for large scale estimates of $\mathrm{CO}_{2}$ evasion. Global Biogeochem. Cycles 25, GB3025.

Wallmann K. (2001) Controls on the Cretaceous and Cenozoic evolution of seawater composition, atmospheric $\mathrm{CO}_{2}$ and climate. Geochim. Cosmochim. Acta 65, $3005-3025$. 
Wang Y., McDonald E., Amundson R., McFadden L. and Chadwick O. (1996) An isotopic study of soils in chronological sequences of alluvial deposits, Providence Mountains, California. Bull. Geol. Soc. Am. 108, 379-391.

West A. J. (2012) Thickness of the chemical weathering zone and implications for erosional and climatic drivers of weathering and for carbon-cycle feedbacks. Geology 40, 811-814.

West A. J., Galy A. and Bickle M. (2005) Tectonic and climatic controls on silicate weathering. Earth Planet. Sci. Lett. 235, 211-228.

White A. F. and Blum A. E. (1995) Effects of climate on chemical weathering in watersheds. Geochim. Cosmochim. Acta 59, 1729- 1747.

White A. F., Blum A. E., Schulz M. S., Bullen T. D., Harden J. W. and Peterson M. L. (1996) Chemical weathering rates of a soil chronosequence on granitic alluvium: I. Quantification of mineralogical and surface area changes and calculation of primary silicate reaction rates. Geochim. Cosmochim. Acta 60, 2533-2550.

White A. F., Blum A. E., Bullen T. D., Vivit D. V., Schulz M. and Fitzpatrick J. (1999a) The effect of temperature on experimental and natural chemical weathering rates of granitoid rocks. Geochim. Cosmochim. Acta 63, 3277-3291.

White A. F., Bullen T. D., Vivit D. V., Schulz M. S. and Clow D. W. (1999b) The role of disseminated calcite in the chemical weathering of granitoid rocks. Geochim. Cosmochim. Acta 63, 1939-1953.

White A. F., Bullen T. D., Schulz M. S., Blum A. E., Huntington T. G. and Peters N. E. (2001) Differential rates of feldspar weathering in granitic regoliths. Geochim. Cosmochim. Acta 65, 847-869. 
White A. F., Schulz M. S., Lowenstern J. B., Vivit D. V. and Bullen T. D. (2005) The ubiquitous nature of accessory calcite in granitoid rocks: implications for weathering, solute evolution, and petrogenesis. Geochim. Cosmochim. Acta 69, 1455-1471.

White A. F., Schulz M. S., Stonestrom D. A., Vivit D. V., Fitzpatrick J., Bullen T. D., Maher K. and Blum A. E. (2009) Chemical weathering of a marine terrace chronosequence, Santa Cruz, California. Part II: solute profiles, gradients and the comparisons of contemporary and long-term weathering rates. Geochim. Cosmochim. Acta 73, 2769-2803.

Willenbring J. K. and von Blanckenburg F. (2010) Long-term stability of global erosion rates and weathering during late- Cenozoic cooling. Nature 465, 211-214.

Willett S. D. (1999) Orogeny and orography: the effects of erosion on the structure of mountain belts. J. Geophys. Res. 104, 28957- 28981.

Willett S. D., McCoy S. W., Taylor Perron. J., Goren L. and Chen C. Y. (2014) Dynamic reorganization of River Basins. Science 343, 1248765-1248765.

Zapata-Rios X., McIntosh J., Rademacher L., Troch P. A., Brooks P. D., Rasmussen C. and Chorover J. (2015) Climatic and landscape controls on water transit times and silicate mineral weathering in the critical zone. Water Resour. Res. 51, 60366051.

Zeebe R. E. (2012) LOSCAR: long-term Ocean-atmosphere- Sediment CArbon cycle Reservoir Model v2.0.4. Geosci. Model Develop. 5, 149-166. 


\subsubsection{Tables}

The following table is included in the appended excel workbook

"Ibarra_Chapter3_Tables.xlsx" and was published with the original publication (Ibarra et al., 2016).

Table 1. Summary statistics for concentration-runoff fits and flux-weighted data 


\subsubsection{Figures}

Figure 1. Location of datasets and conceptual model for concentration-runoff processes.

(a) Map of catchments included in this analysis. For overlapping sites the numbers are listed by group (e.g., 10×) (see Table A1). PNW - Pacific Northwest, SN - Sierra

Nevada. (b) Catchment-scale conceptual model used to illustrate fluxes shown in Eqs. (2) and (3), and the framework presented in Fig. 2. In this study we only analyze concentration-runoff relationships of end-member silicate catchments. Analysis of concentration-runoff relationships of large rivers by Maher and Chamberlain (2014) and von Blanckenburg et al. (2015) was carried out on datasets from heterogenous, mixlithology datasets (e.g., Gaillardet et al., 1999; Moon et al., 2014).

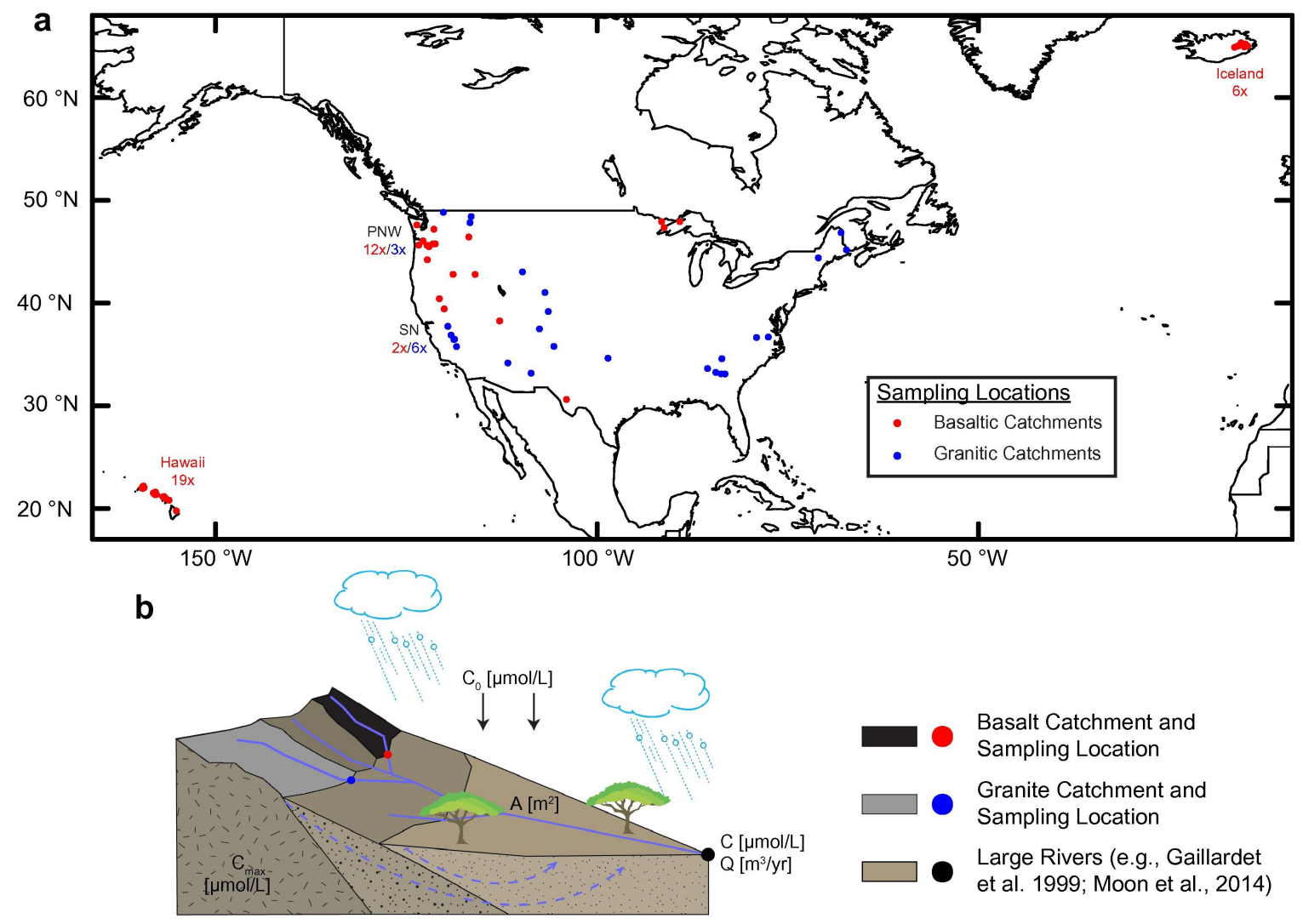


Figure 2 (next page). Framework for evaluating catchment solute production. (a) $\mathrm{SiO} 2(\mathrm{aq})$ concentration as a function of runoff (Eq. (3)). Illustrated catchments types are from Maher (2011). Constant Damköhler numbers $(D a)$ are denoted as horizontal dashed lines of constant concentration. Note log-scale runoff axis. (b) $\mathrm{SiO}_{2}$ (aq) fluxes as a function of runoff and illustration of weathering potential (WP) (Eqs. (4)-(6)). Weathering potential is expressed in percent $\left(W P_{\text {norm }}[\%]\right)$. Note that both axes are on logscales. 
a

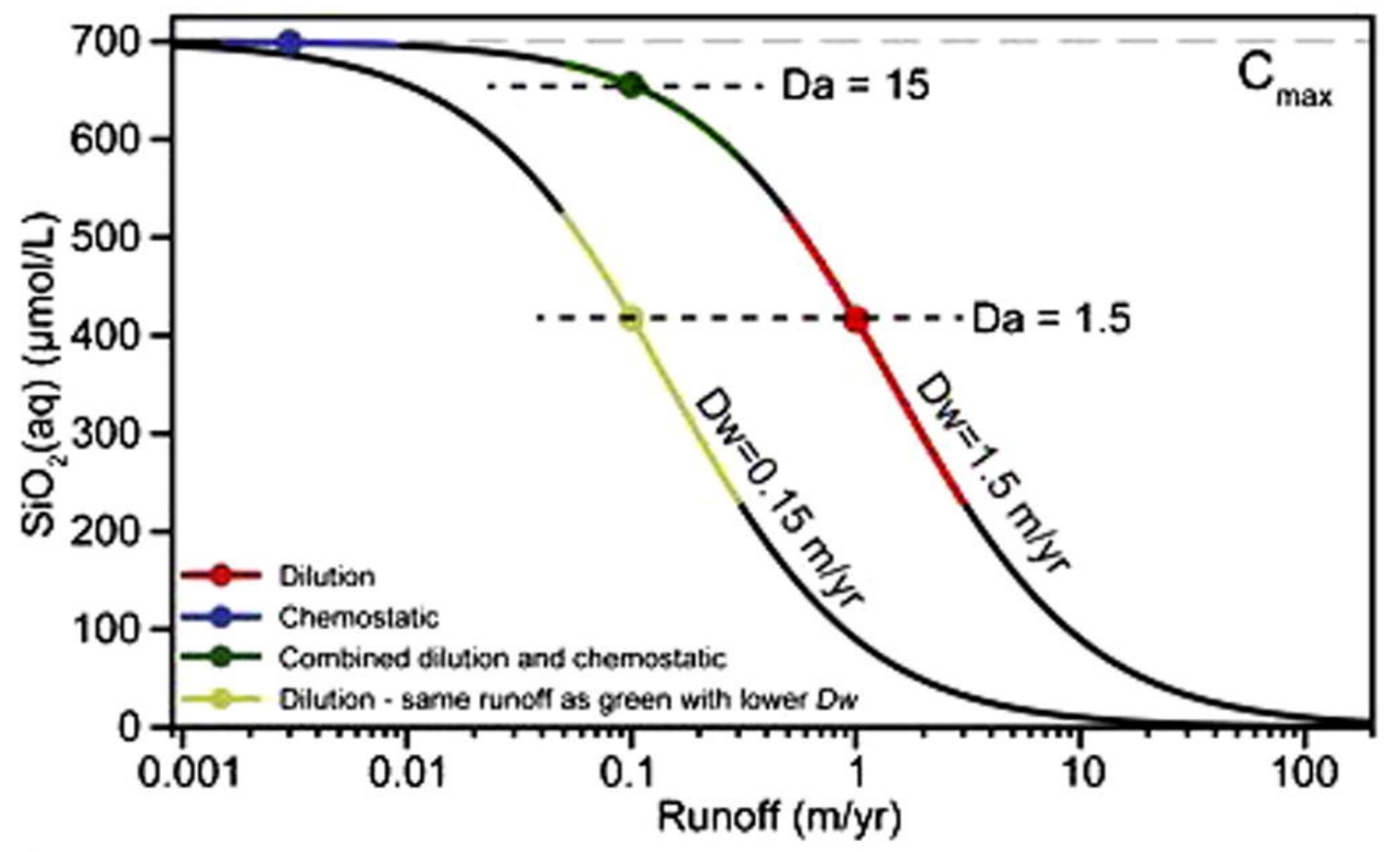

b

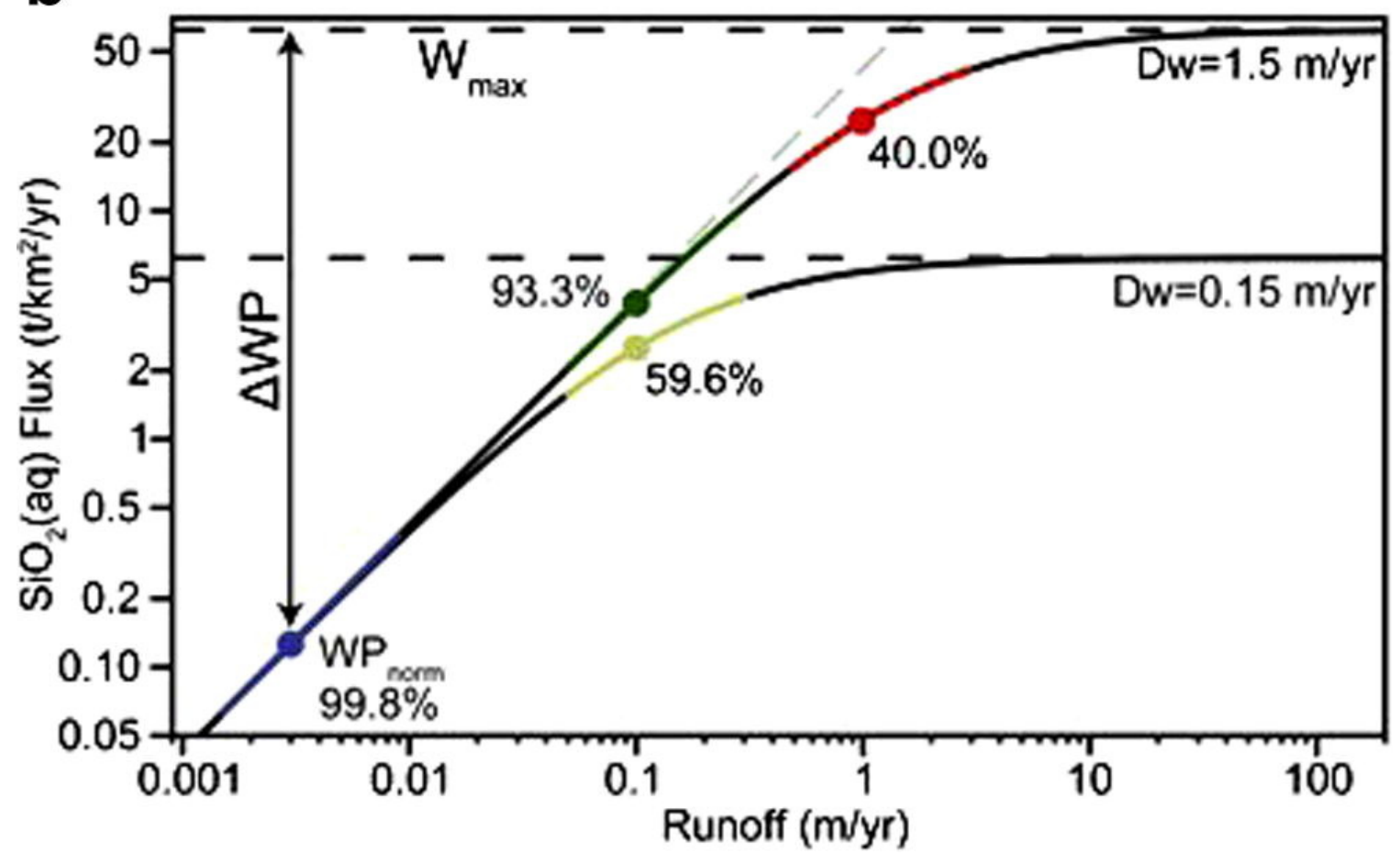


Figure 3 (next page). Illustrative correction of concentration-runoff relationship for nonzero $\mathrm{C}_{0}$ within the solute production framework; solid lines are a hypothetical observed concentration-runoff relationship and the dashed lines are the silicate weathering component only. Log-scale axes are as in Fig. 2. (a) $\mathrm{SiO}_{2}$ (aq) concentration as a function of runoff (Eqs. (2) and (3)). Values of Cmax and $\mathrm{C} 0$ are annotated. (b) $\mathrm{SiO}_{2}$ (aq) fluxes as a function of runoff showing that the correction for $C_{0}$ contributions results in a plateau of the weathering flux $\left(W_{\max }\right)$. Chemostatic portions of the curve are annotated. 

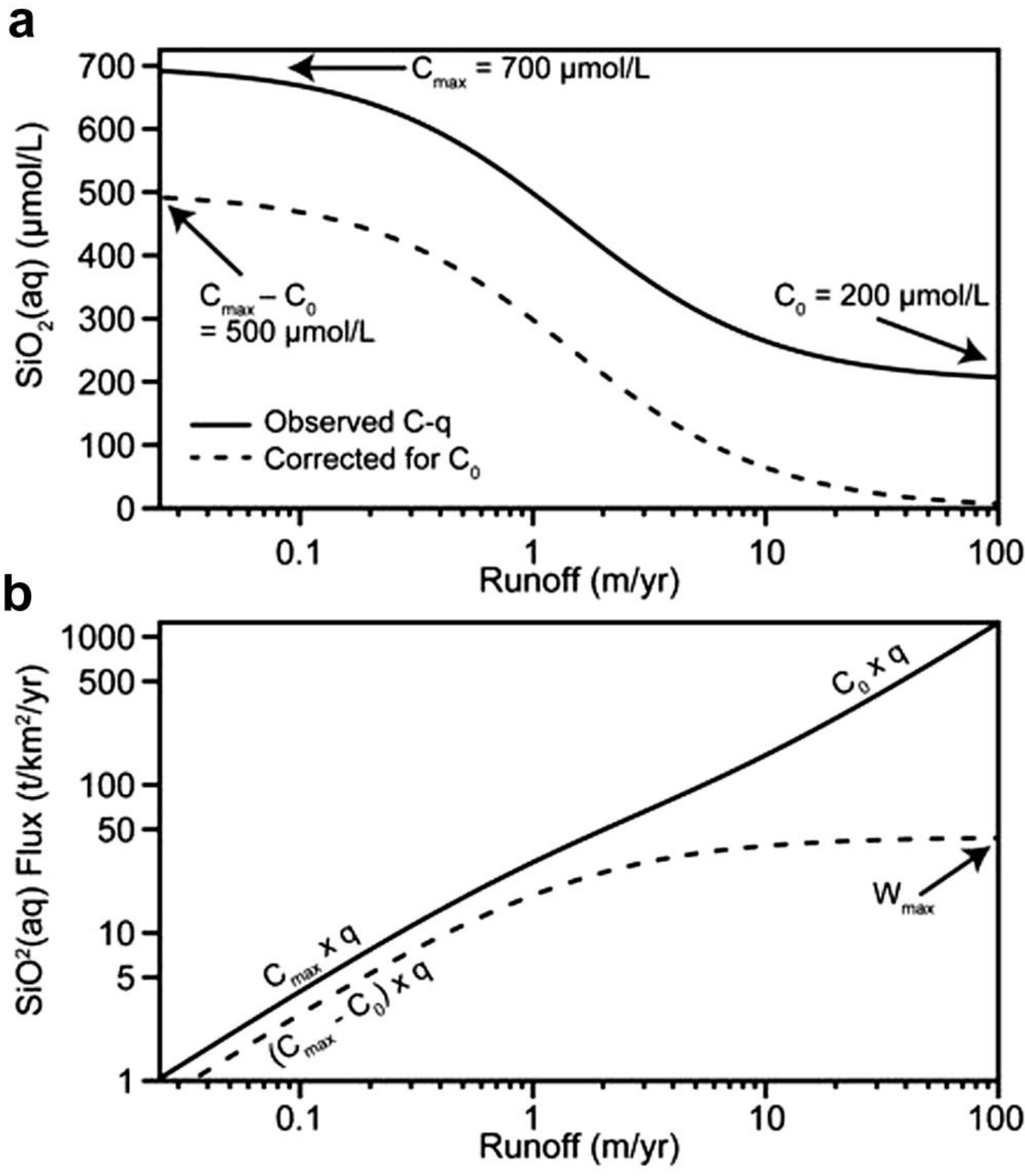
Figure 4 (next page). Concentration-runoff fits for catchments; plotted as concentration as a function of runoff (Eqs. (1) and (2)) for (a) $\mathrm{SiO}_{2}(\mathrm{aq})(\mu \mathrm{mol} / \mathrm{L})$, (b) $\mathrm{Mg}^{2+}(\mu \mathrm{mol} / \mathrm{L})$, (c) $\mathrm{Ca}^{2+}(\mu \mathrm{mol} / \mathrm{L}),(\mathrm{d}) \mathrm{Na}^{*}(\mu \mathrm{mol} / \mathrm{L}),(\mathrm{e}) \mathrm{HCO}_{3}{ }^{-}(\mu \mathrm{mol} / \mathrm{L})$, (f) cation-equivalent $(\mu \mathrm{eq} / \mathrm{L})$, and $(\mathrm{g})$ total dissolved solids $(\mathrm{mg} / \mathrm{L})$. The median sampled runoff is denoted by dots (diamonds for chemostatic catchments and circles for catchments demonstrating dilution) and lines are plotted for the full range of paired runoff and solute observations from each catchment. Note that both axes are log-scaled. 

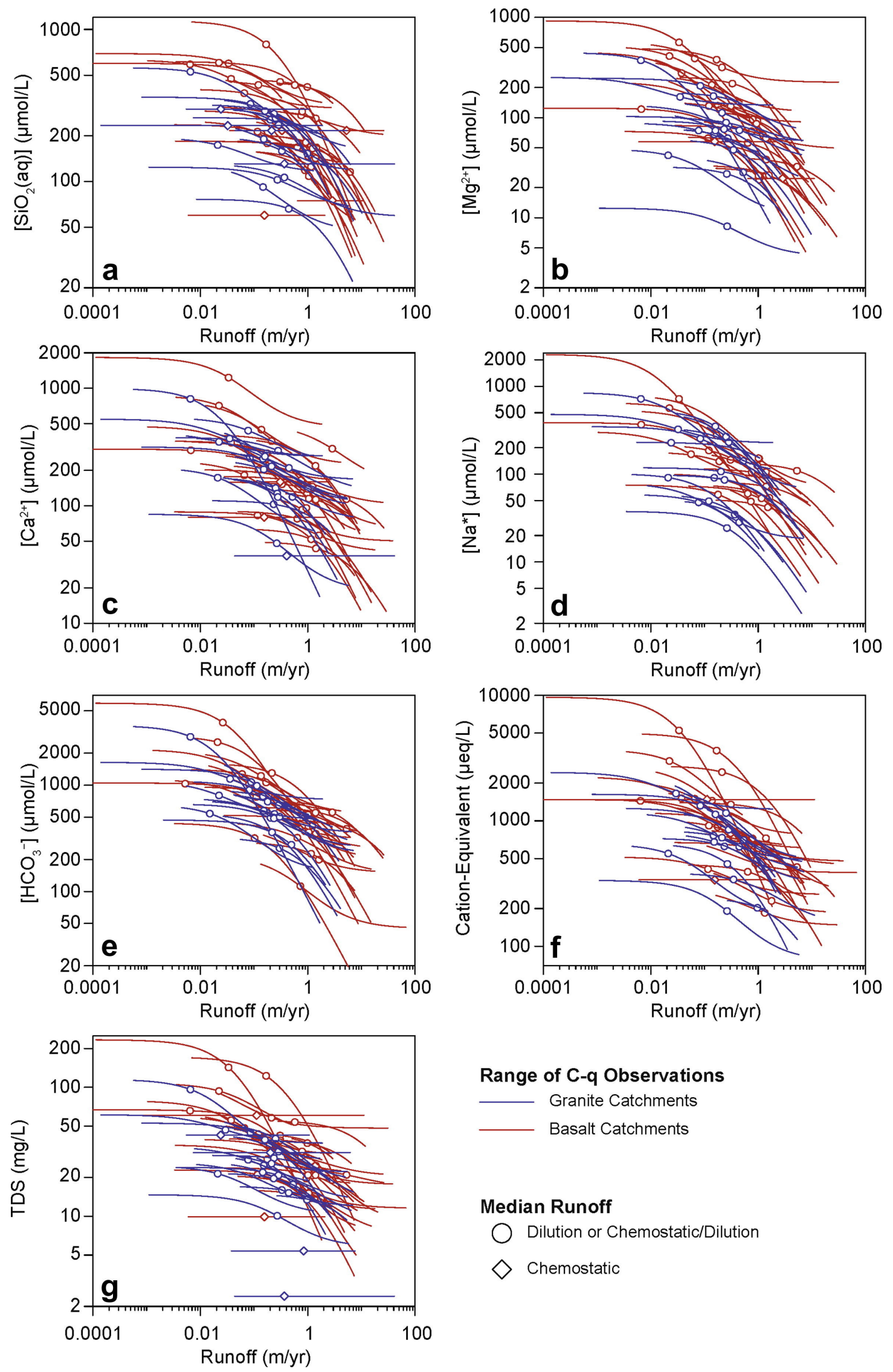

Range of C-q Observations

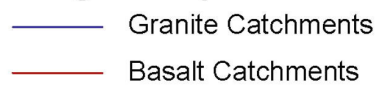

Median Runoff

Dilution or Chemostatic/Dilution

$\diamond$ Chemostatic 
Figure 5 (next page). $C_{0}$-corrected concentration-runoff fits and $C_{\max }$ distributions. Concentration-runoff fits are displayed as in Fig. 4, corrected for C0 (as demonstrated in Fig. 2) for (a) $\mathrm{SiO}_{2}(\mathrm{aq})(\mu \mathrm{mol} / \mathrm{L}),(\mathrm{b}) \mathrm{Mg}^{2+}$ ( $\left.\mu \mathrm{mol} / \mathrm{L}\right)$, (c) $\mathrm{Ca}^{2+}(\mu \mathrm{mol} / \mathrm{L})$, (d) $\mathrm{Na}^{*}$ ( $\mu \mathrm{mol} / \mathrm{L}),(\mathrm{e}) \mathrm{HCO}_{3}{ }^{-}(\mu \mathrm{mol} / \mathrm{L}),(\mathrm{f})$ cation-equivalent $(\mu \mathrm{eq} / \mathrm{L})$, and $(\mathrm{g})$ total dissolved solid $(\mathrm{mg} / \mathrm{L}) . C_{\max }$ distributions are displayed with summary statistics (mean (diamonds), median, interquartile range (IQR) and 95\% range) color coded by catchment type (granite or basalt). Also shown (e.g., 1.50×) is a comparison of the mean basalt $C_{\max }$ to the mean granite $C_{\text {max }}$ value. 

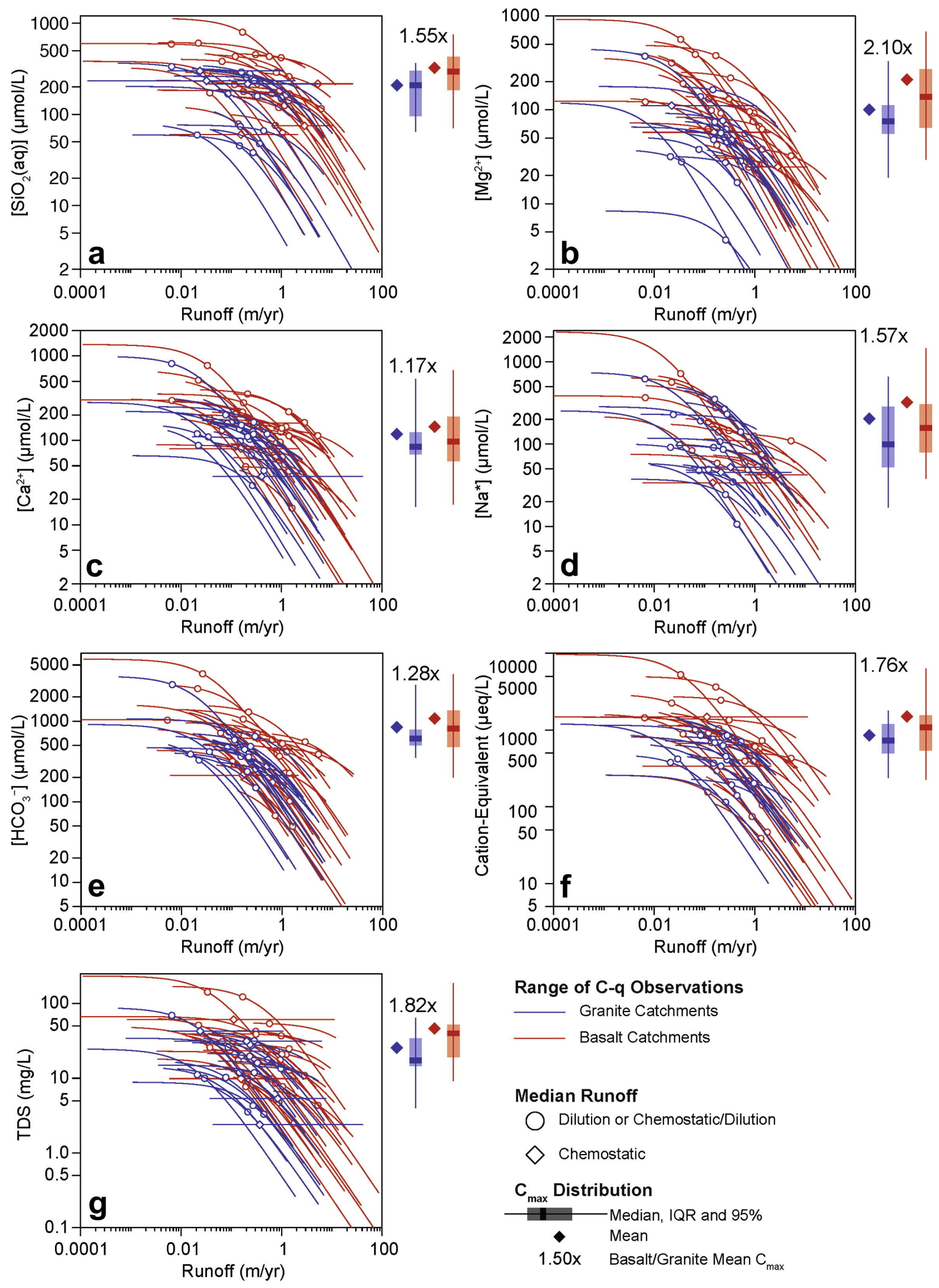

Range of C-q Observations

- Granite Catchments

Basalt Catchments

Median Runoff

Dilution or Chemostatic/Dilution

$\diamond$ Chemostatic

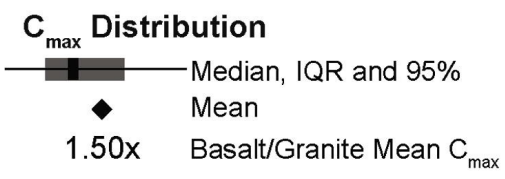


Figure 6 (next page). Flux-weighted concentration pairs. Fluxed weighted concentration-runoff relationships. Each point represents a single catchment. $C_{\max }$ values, denoted in square brackets, are determined from the 95 th percentile of concentrations for each catchment type (granite or basalt) following Maher and Chamberlain (2014) (see their Fig. S3 and Table S1). Dw values contoured here, and reported in Table A9, assume the 95th percentile $C_{\max }$ value. 

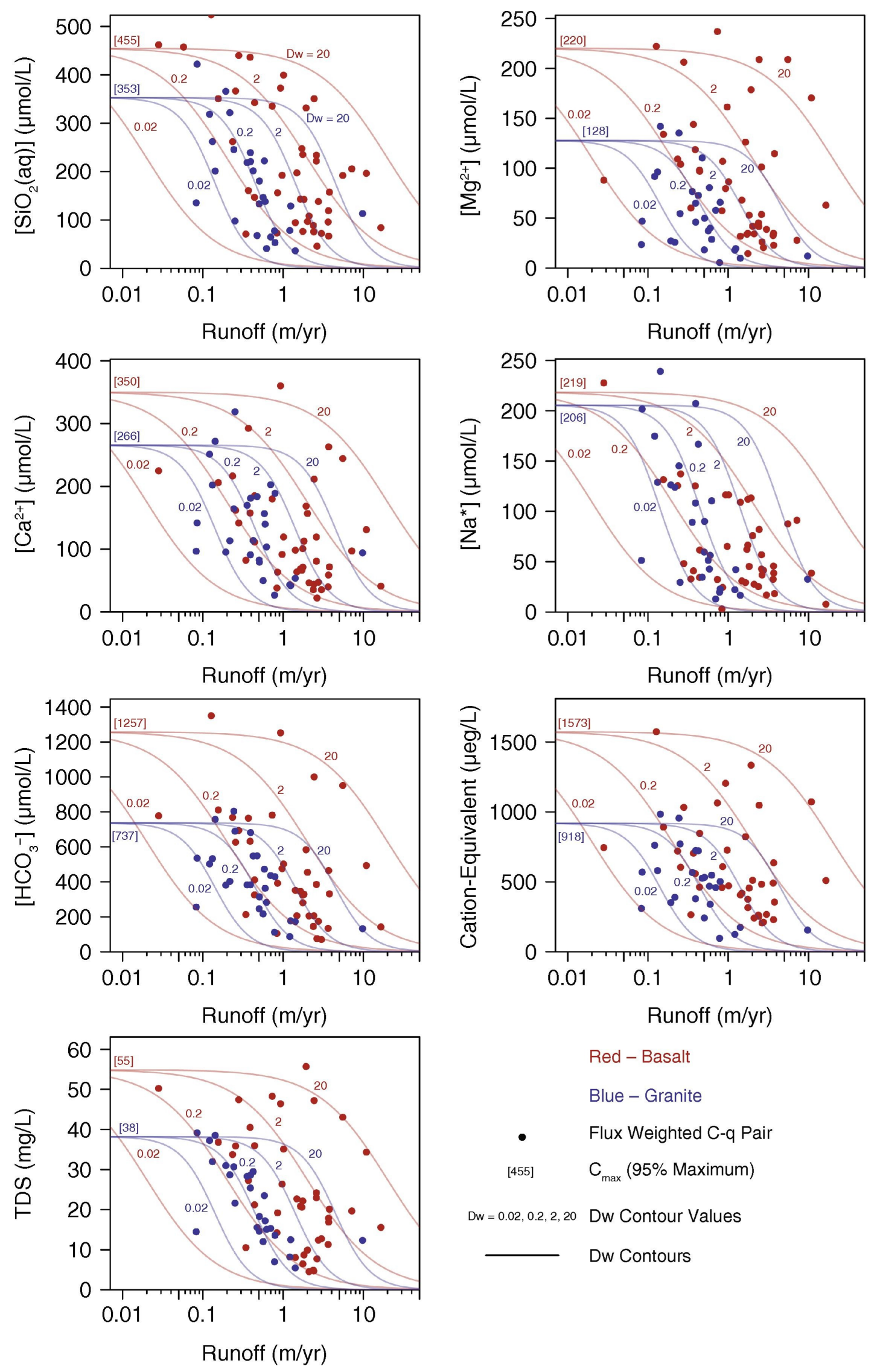

Dw $=0.02,0.2,2,20 \quad$ Dw Contour Values

Dw Contours 
Figure 7 (next page). Concentration-runoff derived maximum concentration $\left(C_{\max }\right)$ vs. water temperature. Scatter plots of average water temperature vs. concentration-runoff derived $C_{\max }$ values $\left(C_{0}\right.$-corrected $C_{\max }$ values) for (a) $\mathrm{SiO}_{2}$ (aq) $(\mu \mathrm{mol} / \mathrm{L}),(\mathrm{b}) \mathrm{Mg}^{2+}$ ( $\mu \mathrm{mol} / \mathrm{L}),(\mathrm{c}) \mathrm{Ca}^{2+}(\mu \mathrm{mol} / \mathrm{L}),(\mathrm{d}) \mathrm{Na}^{*}(\mu \mathrm{mol} / \mathrm{L}),(\mathrm{e}) \mathrm{HCO}_{3}{ }^{-}$( $\left.\mu \mathrm{mol} / \mathrm{L}\right)$, (f) cation-equivalent $(\mu \mathrm{eq} / \mathrm{L})$, and $(\mathrm{g})$ total dissolved solid $(\mathrm{mg} / \mathrm{L})$. Temperature is the average of the water temperature during sample collection, not the air temperature. Cmax errors (reported in Tables A2-A8) are $1 \sigma$. For clarity temperature errors are not included, but are reported in Table A1. Linear regressions are individually calculated for each sample group (basalts and granites), using the Cmax and temperature population statistics (mean and errors). Only statistically significant regressions are illustrated and reported ( $p$-value $<0.05$ ). The temperature-concentration relationships $(\mathrm{dC} / \mathrm{dT})$ are reported for the statistically significant regressions and $95 \%$ confidence intervals are shaded. 

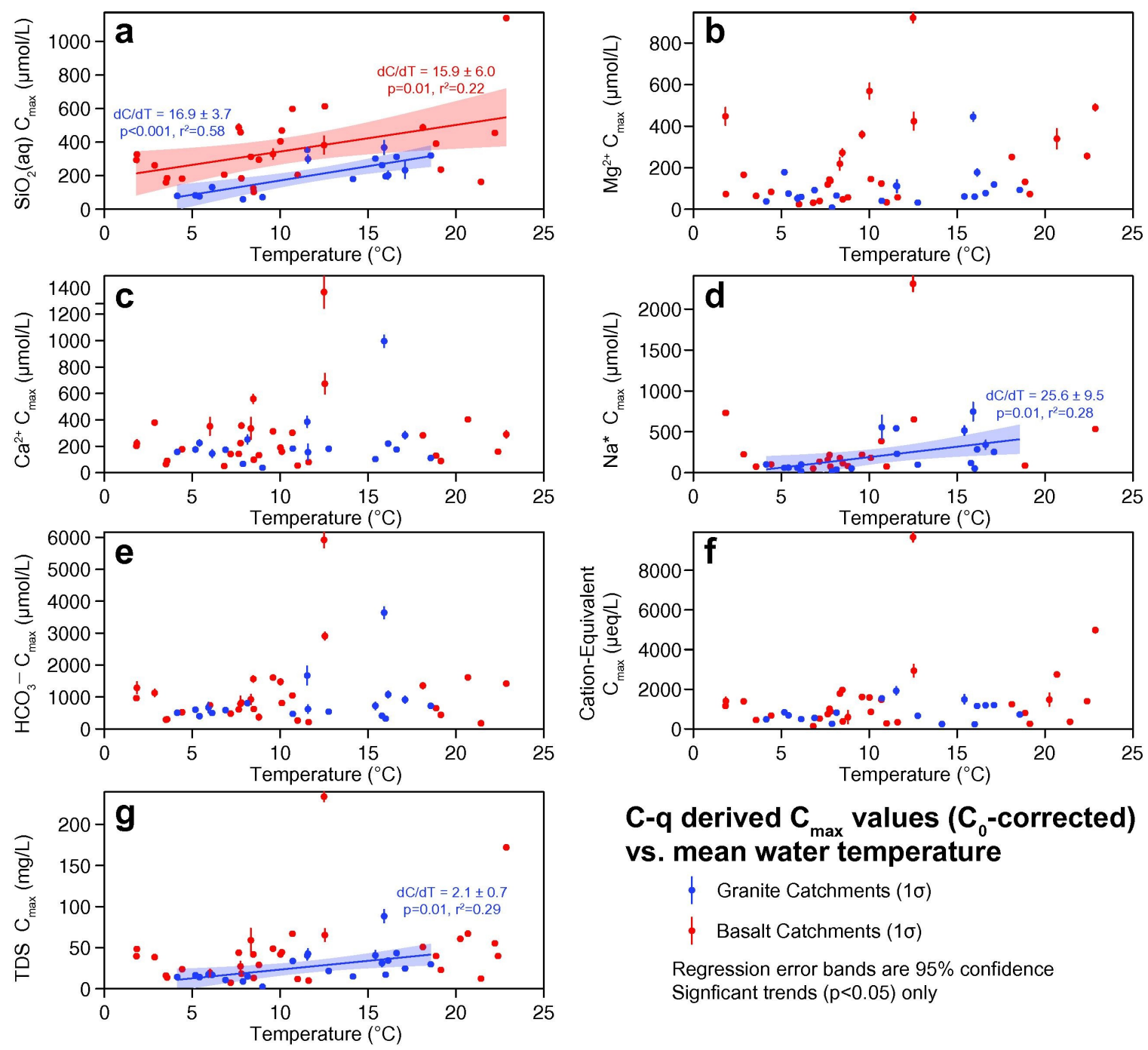

\section{C-q derived $\mathbf{C}_{\max }$ values ( $\mathbf{C}_{0}$-corrected)} vs. mean water temperature

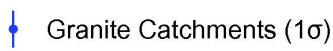

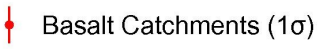

Regression error bands are $95 \%$ confidence

Signficant trends $(p<0.05)$ only 
Figure 8 (next page). Histograms of saturation indices (i.e., $\log (I A P / K))$ for select primary and secondary minerals. Saturation index calculations carried out in Geochemist's Workbench (Bethke and Yeakel, 2015) using the Thermoddem database (version: 1lv12; Blanc et al., 2012; Marty et al., 2015). Here we include all available samples with aluminum concentrations $(n=1952)$ from the USGS NWIS database from basaltic and granitic catchments as well as from the Icelandic catchments (Eiriksdottir et al., 2013, 2015). Data from chemostatic catchments are highlighted as solid bars. For smectite we use the end-member half reactions for $\mathrm{Na}, \mathrm{Ca}$ and $\mathrm{Mg}$ (Smectite- $\mathrm{Na}=$ $\mathrm{Na}_{0.34} \mathrm{Al}_{2.34} \mathrm{Si}_{3.66} \mathrm{O}_{10}(\mathrm{OH})_{2} ;$ Smectite-Ca $=\mathrm{Ca}_{0.17} \mathrm{Al}_{2.34} \mathrm{Si}_{3.66} \mathrm{O}_{10}(\mathrm{OH})_{2} ;$ Smectite-Mg $=$ $\left.\mathrm{Mg}_{0.17} \mathrm{Al}_{2.34} \mathrm{Si}_{3.66} \mathrm{O}_{10}(\mathrm{OH})_{2}\right)$. The "Albite (High)" histogram uses thermodynamic data for the highly disordered albite end-member more typically found in basalts ( $c f$. Stefánsson et al., 2001). 

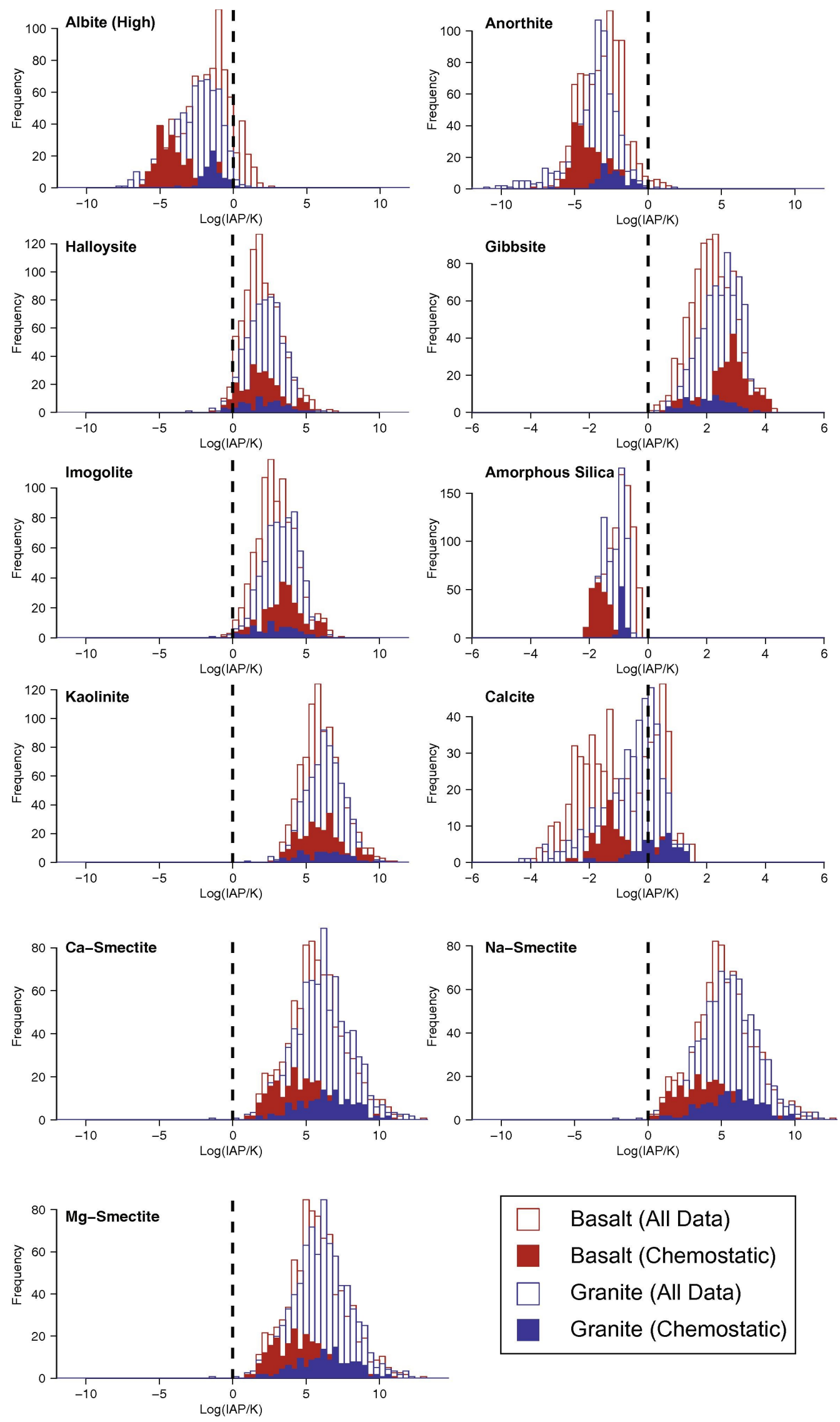

Basalt (All Data)

Basalt (Chemostatic)

Granite (All Data)

Granite (Chemostatic) 
Figure 9. Activity diagrams of the smectite-kaolinite system for $\mathrm{Ca}-\mathrm{Mg}$ and $\mathrm{Ca}-\mathrm{Na}$.

Following Bluth and Kump (1994) activity diagrams were constructed assuming that log $\left[\mathrm{SiO}_{2}(\mathrm{aq})\right]=10-3$ to $10-3.7$ and temperature $=15^{\circ} \mathrm{C}$. Brackets denote activity. All available data from the USGS NWIS database from basaltic and granitic catchments as well as from the Icelandic catchments (Eiriksdottir et al., 2013, 2015) were speciated using Geochemist's Workbench (Bethke and Yeakel, 2015) using the Thermoddem database (version: 1lv12; Blanc et al., 2012; Marty et al., 2015) to calculate log $\left[\mathrm{Ca}^{2+}\right] /\left[\mathrm{H}^{+}\right] 2(\mathrm{n}=7853), \log \left[\mathrm{Na}^{+}\right] /\left[\mathrm{H}^{+}\right](\mathrm{n}=8031)$, and $\log \left[\mathrm{Mg}^{2+}\right] /\left[\mathrm{H}^{+}\right] 2(\mathrm{n}=7835)$.
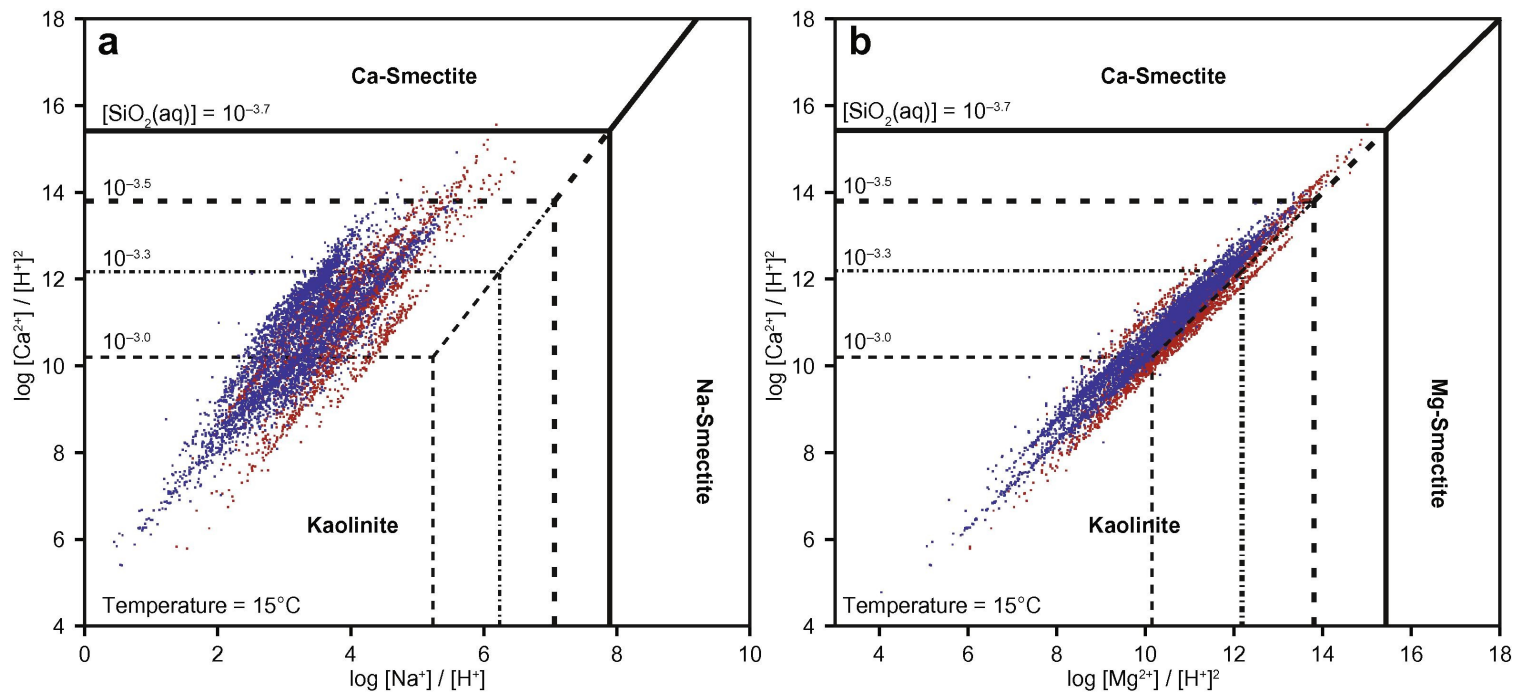
Figure 10 (next page). Concentration-runoff derived Damköhler coefficient $(D w)$ crossplots. Comparison of concentration-runoff derived $D w$ values for basalts (red) and granites (blue) derived using different solutes. Diagonal solid lines are the 1:1 line, and the parallel dashed lines are a factor of two envelope $(2 \times$ and $0.5 \times$ the $1: 1$ line). Note both axis scales are equivalent and are log-scaled. $D w$ distributions are displayed with summary statistics (mean (diamonds), median, interquartile range (IQR) and 95\% range) color coded by catchment type (granite or basalt). Plots compare (a) $\mathrm{SiO}_{2}(\mathrm{aq}) \mathrm{vs} . \mathrm{Mg}^{2+}$, (b) $\mathrm{SiO}_{2}$ (aq) vs. $\mathrm{Ca}^{2+}$, (c) $\mathrm{SiO}_{2}$ (aq) vs. $\mathrm{HCO}_{3}^{-}$, (d) $\mathrm{SiO}_{2}$ (aq) vs. $\mathrm{Na}^{+}$, (e) $\mathrm{SiO}_{2}$ (aq) vs. TDS, (f) cation-equivalent vs. $\mathrm{HCO}_{3}{ }^{-}$, and (g) $\mathrm{Mg}^{2+}$ vs. $\mathrm{Ca}^{2+}$. 

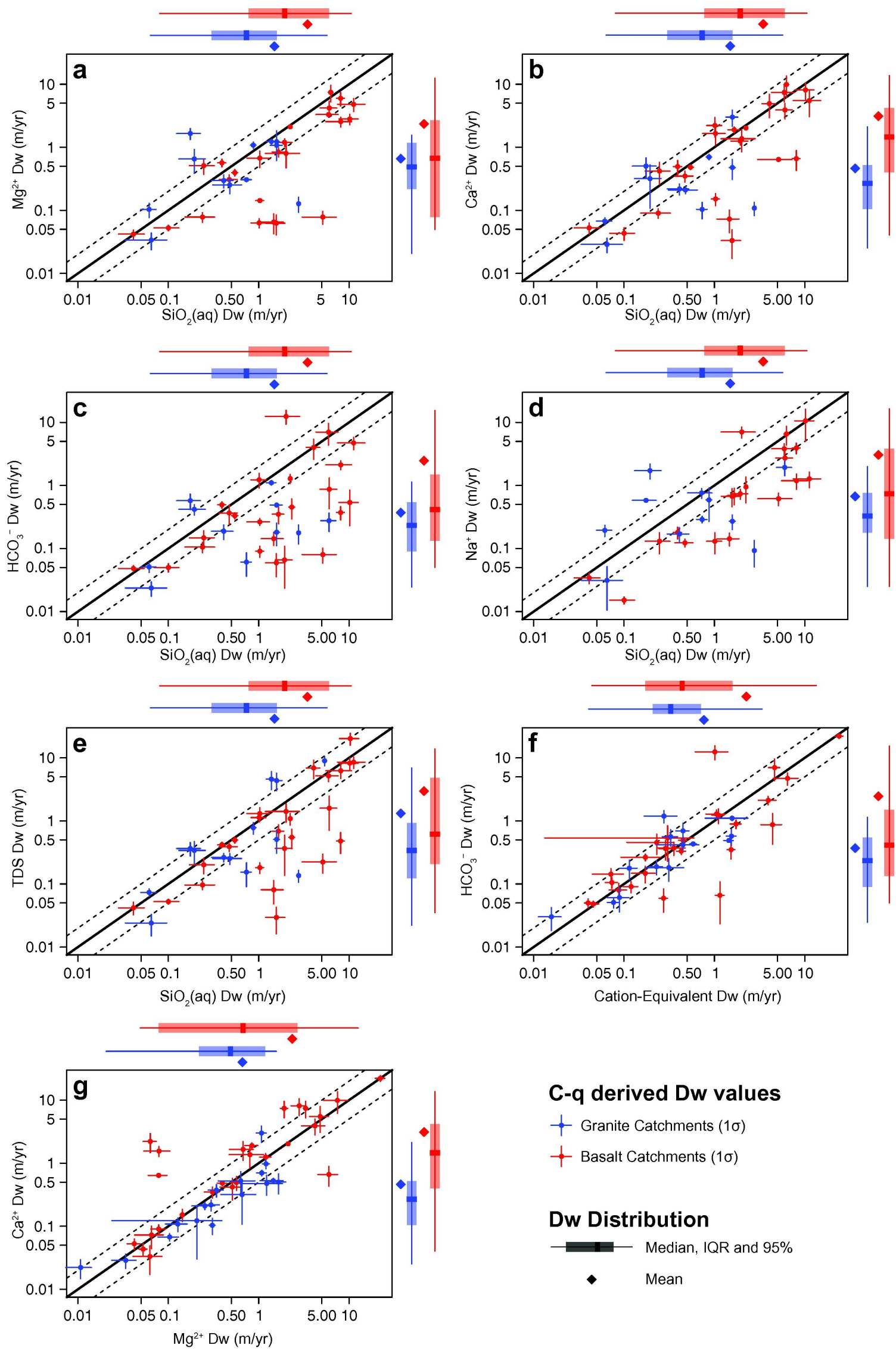

\section{C-q derived Dw values

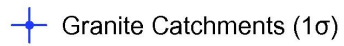 \\ $\uparrow$ Basalt Catchments $(1 \sigma)$}

\section{Dw Distribution}

$\longrightarrow$ Median, IQR and 95\% 
Figure 11. Concentration-runoff derived Damköhler coefficients $(D w)$ vs. water temperature. Scatter plots of average water temperature vs. concentration-runoff derived Dw values for (a) $\mathrm{SiO}_{2}$ (aq), (b) $\mathrm{Mg}^{2+}$, (c) $\mathrm{Ca}^{2+}$, (d) $\mathrm{Na}^{*}$, (e) $\mathrm{HCO}_{3}{ }^{-}$, (f) cation-equivalent, and (g) total dissolved solid. As in Fig. 9, temperature errors are not included but are reported in Table A1. No statistically significant regressions $(p$-value $<0.05)$ exist between $D w$ and temperature in this dataset.
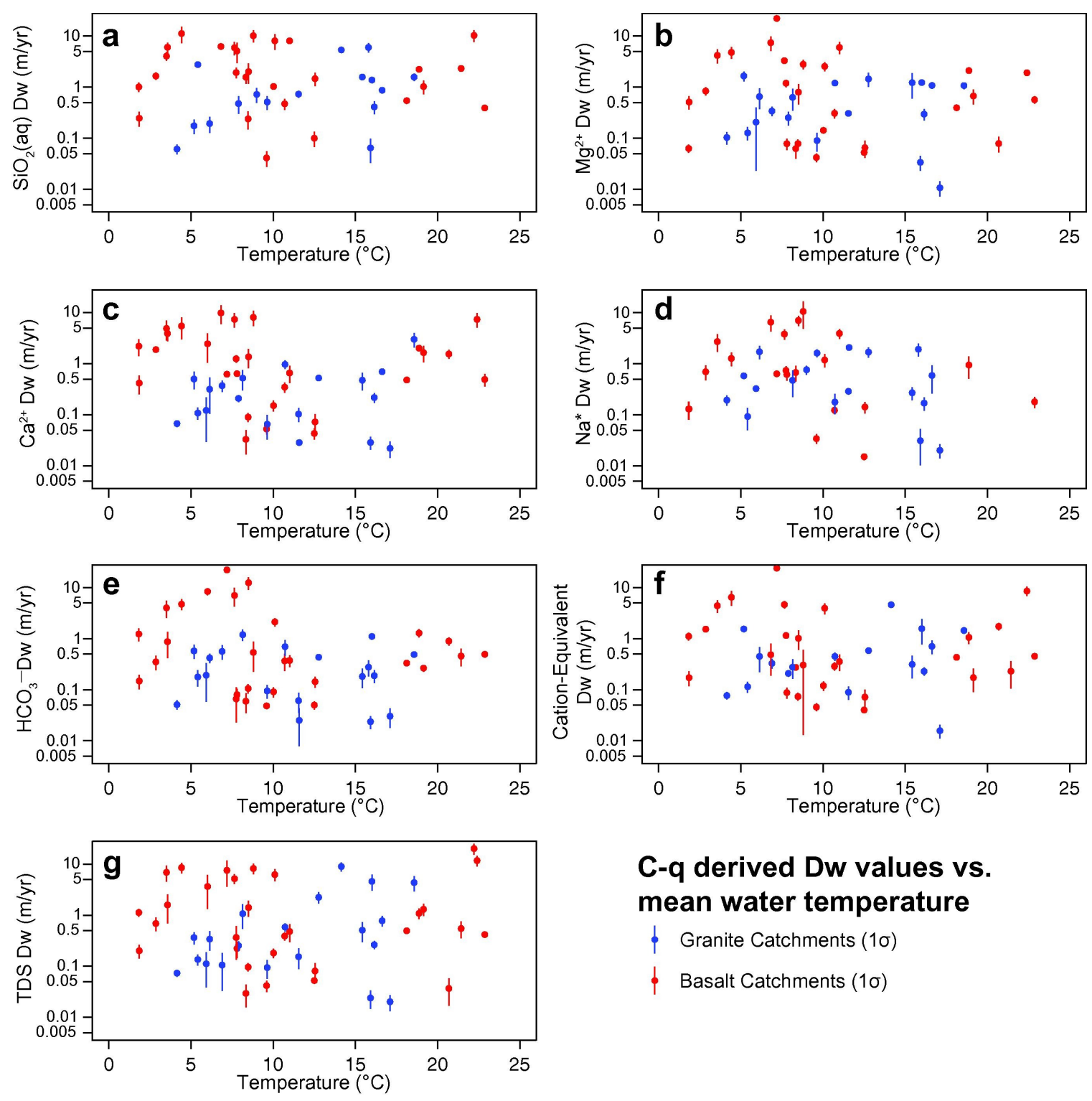

\section{C-q derived Dw values vs. mean water temperature}

$\downarrow$ Granite Catchments (10)

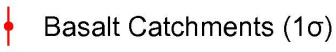


Figure 12. Weathering potential. Maximum weathering potential $(\Delta W P)$ vs. the median normalized weathering potential $\left(W P_{\text {norm }}\right)$ for basalts (red) and granites (blue) derived for (a) $\mathrm{SiO}_{2}$ (aq) and (b) $\mathrm{HCO}_{3}{ }^{-}$. Note the log-scale for $\Delta W P$ (y-axis). Error bars for $\Delta W P$ are the minimum and maximum range of observations. Error on $W P_{\text {norm }}$ are not shown for clarity but can be calculated using the minimum and maximum runoff values given in Tables A2 and A6. Linear regressions with confidence intervals are individually illustrated for each sample group (basalts and granites).
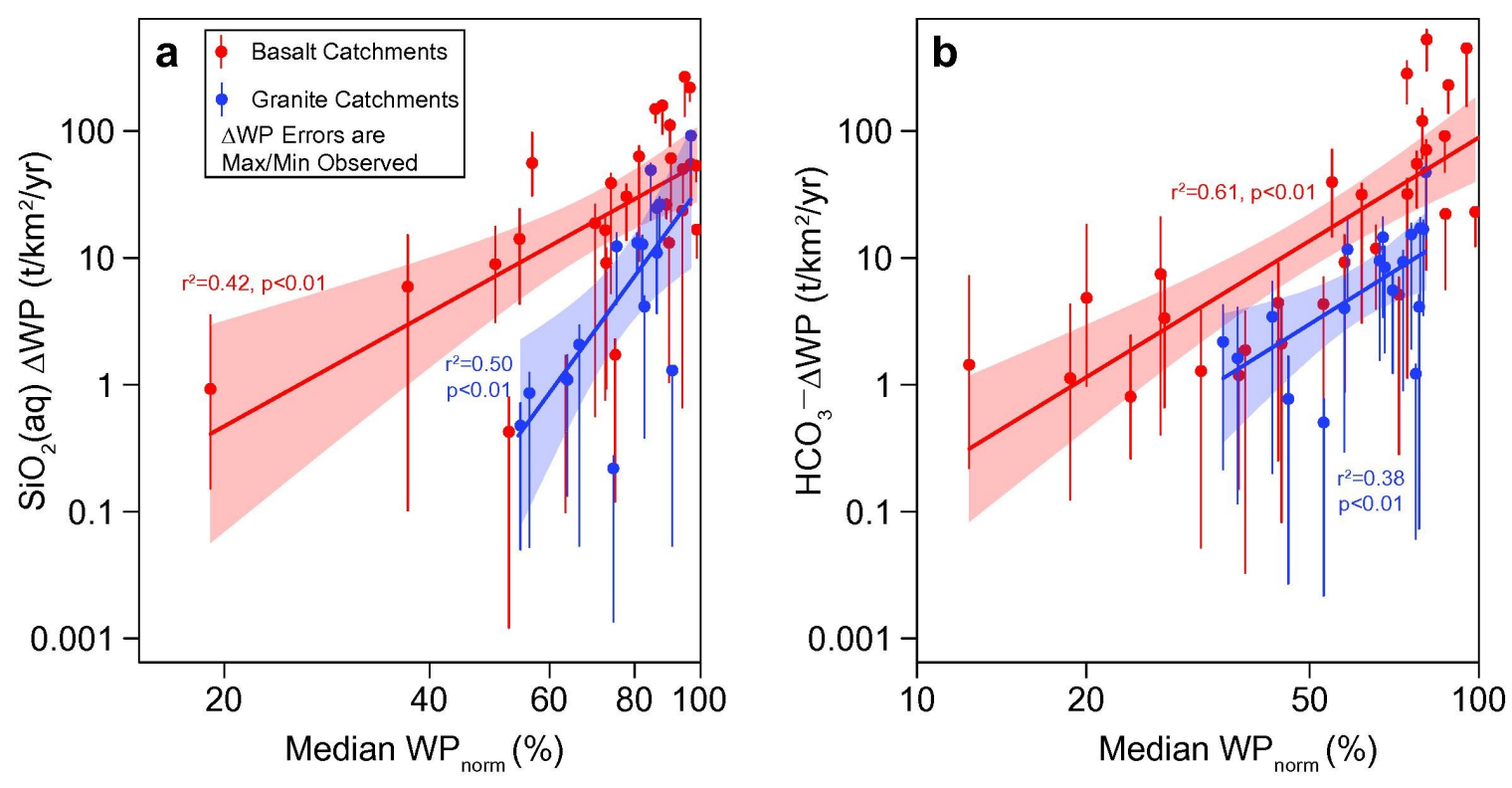
Figure 13 (next page). $\mathrm{SiO}_{2}(\mathrm{aq})$ and $\mathrm{HCO} 3-$ fluxes. (a) $\mathrm{SiO}_{2}(\mathrm{aq})$ fluxes $\left(\mathrm{t} / \mathrm{km}^{2} / \mathrm{yr}\right)$ and (b) $\mathrm{HCO}_{3}{ }^{-}$fluxes $\left(\mathrm{t} / \mathrm{km}^{2} / \mathrm{yr}\right)$. Note both axes are log-scales. Heavy plotted lines are the mean fluxes (granite-blue; basalt-red) based on the $C_{\max }$ and $D w$ distributions (Fig. 5, Table 1) derived from the granite (thin lighter blue) and basalt (thin lighter red) catchments (see text). $W_{\max }$ distributions are displayed with summary statistics (mean (diamonds), median, interquartile range (IQR) and 95\% range) color coded by catchment type (granite or basalt). Previously derived flux-runoff relationships by Bluth and Kump (1994) are also plotted for reference. 

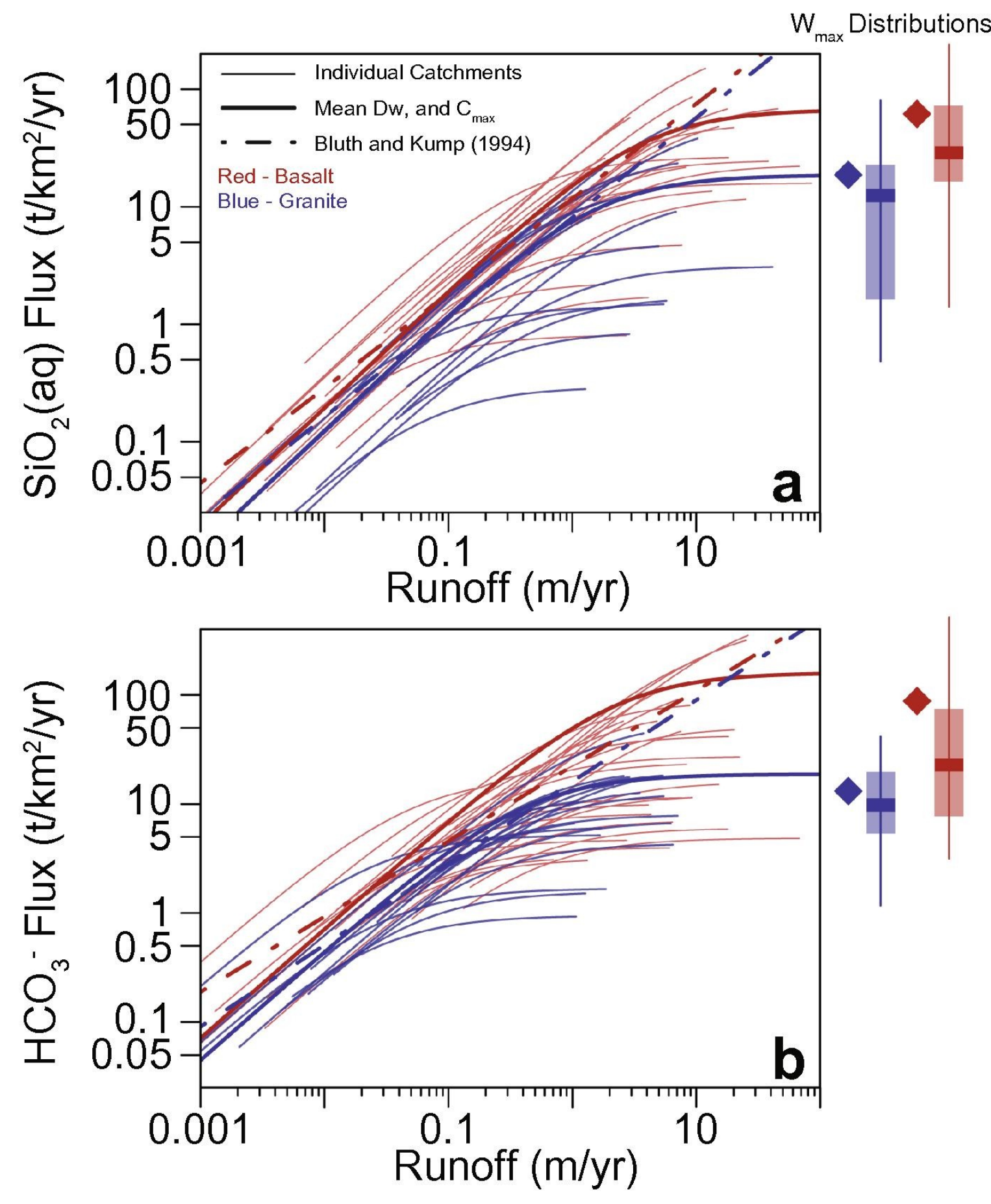
Figure 14 (next page). Weatherability of basalt vs. granite catchments. (a) Basalt/granite weatherability, calculated from the average area-normalized basalt/granitic fluxes derived from the average $C_{\max }$ and $D w$ values (Table 1, Fig. 9a,b) for $\mathrm{SiO}_{2}(\mathrm{aq})$ (thick black line), and $\mathrm{HCO}_{3}{ }^{-}$(thick gray line) as a function of runoff. Errors associated with the parameters used to calculate the weatherability curves are reported in Table 1. Global average runoff (thick red horizontal line) is calculated from Dai and Trenberth (2002) (panel c) with an uncertainty band assuming a 10\% increase/decrease in runoff for a doubling of global pCO2 (based on Manabe et al., 2004) up to a five times doubling. (b) Range of weatherability from previous studies (Horton et al., 1999; Berner, 2006b, 2008; Hartmann, 2009; Hartmann et al., 2010; Hartmann and Moosdorf, 2011). (c) Areaweighted global river runoff distribution (mean and $95 \%$ range) binned by latitude $\left(3^{\circ}\right.$ bins) derived from the volumetric discharge and variance of observations from the 200 largest rivers reported by Dai and Trenberth (2002). Calculated by area-weighting and combining the binned northern and southern hemisphere runoff averages. (d) Mean basalt/granite $\mathrm{SiO}_{2}(\mathrm{aq})$ weatherability (mean and 95\% range) vs. latitude (binned at $3^{\circ}$ latitude bands) based on the modern runoff distribution. Calculated by area-weighting the binned northern and southern hemisphere runoff averages (panel c) and multiplying by the $\mathrm{SiO}_{2}(\mathrm{aq})$ runoff-dependent weatherability relationship (panel b) assuming $100 \%$ basalt proportion relative to granites. 

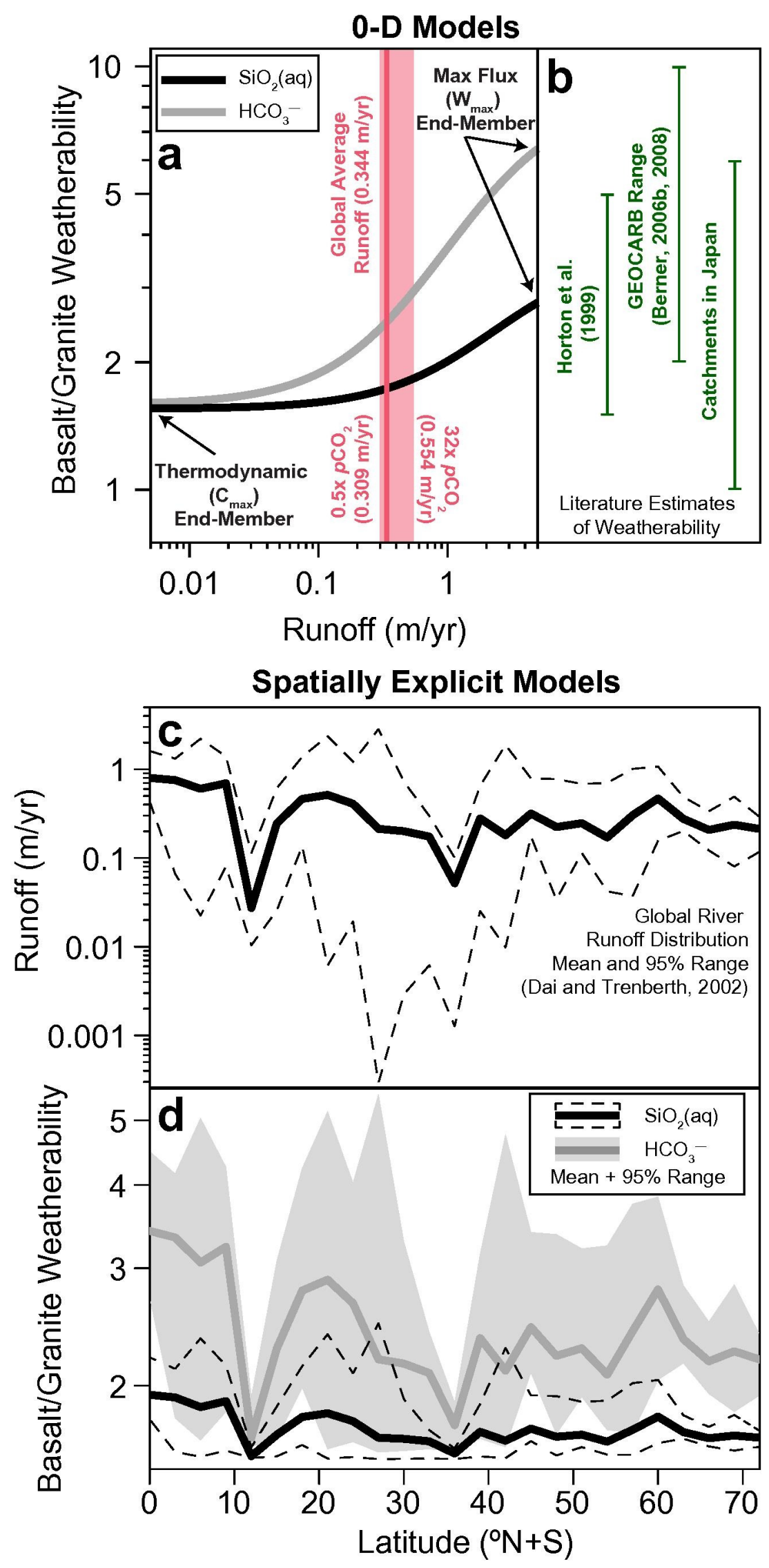


\subsection{Concentration-discharge patterns of weathering prodcuts from global rivers}

Daniel E. Ibarra ${ }^{1}$, Seulgi Moon ${ }^{2}$, Jeremy K. Caves ${ }^{3}$, C. Page Chamberlain ${ }^{1}$, Kate Maher ${ }^{4}$

${ }^{1}$ Earth System Science, Stanford University, Stanford, CA 94305-4216, USA

${ }^{2}$ Earth, Planetary, and Space Sciences, University of California, Los Angeles, CA 900951567, USA

${ }^{3}$ Earth Science, ETH Zurich, 8092 Zürich, Switzerland

${ }^{4}$ Geological Sciences, Stanford University, Stanford, CA 94305-2115, USA

Reproduced with permission from Ibarra, D.E., Moon, S., Caves, J.K., Chamberlain, C.P., Maher, K., Acta Geochimica. Copyright 2017, Springer.

Licensed under the Creative Commons Attribution-NonCommercial 3.0 http://creativecommons.org/licenses/by-nc/3.0 


\begin{abstract}
Quantifying the functional relationships relating river discharge and weathering products places key constraints on the negative feedback between silicate weathering and climate. In this study we analyze the concentration-discharge relationships of weathering products from global rivers using previously compiled time-series datasets for concentrations and discharge from global rivers. To analyze the nature of the covariation between specific discharge and concentrations, we use both a power law equation and a recently developed solute production equation. The solute production equation allows us to quantify weathering efficiency, or the resistance to dilution at high runoff, via the Damköhler coefficient. These results are also compared to those derived using average concentration-discharge pairs. Both the power law exponent and the Damköhler coefficient increase and asymptote as catchments exhibit increasingly chemostatic behavior, resulting in an inverse relationship between the two parameters. We also show that using the distribution of average concentration-discharge pairs from global rivers, rather than fitting concentration-discharge relationships for each individual river, underestimates global median weathering efficiency by up to a factor of $\sim 10$. This study demonstrates the utility of long time-series sampling of global rivers to elucidate controlling processes needed to quantify patterns in global silicate weathering rates.
\end{abstract}

Keywords: Concentration-discharge, Rivers, Silicate weathering, Solutes 


\subsubsection{Introduction}

Silicate weathering is hypothesized to impose a variable negative feedback on the evolution of Earth's carbon cycle over geologic time (François and Walker, 1992; Kump and Arthur, 1997; Caves et al., 2016). Thus, understanding the functional relationships that couple climate and weathering is critical to modeling how atmospheric $\mathrm{CO}_{2}$ has varied in the past (Kump et al., 2000; Maher and Chamberlain, 2014; Caves et al., 2016). In this study, we compare two such functional relationships relating the covariation of discharge and weathering products using a recently compiled time-series comprising 43 global rivers (Moon et al., 2014). We fit concentration-discharge (C-q) relationships using both a power-law equation (e.g., Bluth and Kump, 1994; Godsey et al., 2009; Moon et al., 2014; Torres et al., 2015) and a solute production model (Maher, 2011; Maher and Chamberlain, 2014; Ibarra et al., 2016).

\subsubsection{Framework and Methods}

The C-q datasets considered in this study is a dataset of 43 large rivers with 3,843 measurements [United Nations Environment Programme (UNEP) - Global Environment Monitoring System (GEMS/Water) supplemented by the Environmental Research Observatory (HYBAM)] compiled by Moon et al. (2014). Our dataset is restricted to sites with the paired runoff and solute concentration $(C)$ data needed to constrain the weathering of primary silicate minerals to secondary minerals $\left[\mathrm{SiO}_{2}(\mathrm{aq}), \mathrm{Mg}^{2+}, \mathrm{Ca}^{2+}\right.$, $\mathrm{Na}^{+}, \mathrm{Cl}^{-}$, and $\left.\mathrm{HCO}_{3}{ }^{-}\right] . \mathrm{Na}^{*}$ is equal to $\mathrm{Na}^{+}-\mathrm{Cl}^{-}$following Moon et al. (2014). All discharge data are normalized by watershed area to calculate changes in specific discharge or runoff $(q,[\mathrm{~m} / \mathrm{yr}])$, which allows for direct area-normalized quantification of 
solute production over orders-of-magnitude differences in discharge. We also compare our weathering efficiency results to the average $C-q$ pair data from Moon et al. (2014) (their Table 2) and Gaillardet et al. (1999) (their Table 1).

We briefly describe the equations used to fit the data and the numerical GaussNewton method used for fitting the $C-q$ relationships. Many studies of modern weathering use power-law relationships (PLM hereafter) between concentration and runoff or discharge (e.g., Bluth and Kump, 1994; Godsey et al., 2009; Moon et al., 2014; Torres et al., 2015). Following previous work, we use the form:

$$
C=a q^{b}
$$

where $C$ is the solute concentration $[\mu \mathrm{mol} / \mathrm{L}], q$ is the paired instantaneous runoff, and $a$ and $b$ are the fitted parameters. For weathering solutes, $b$ is typically less than 1 , resulting in a convex-up dilution relationship (decreasing concentration with increasing runoff). Numerous models have been proposed to explain the observation that power-law relationships are observed across an array of catchments (cf. Godsey et al., 2009; Torres et al., 2015).

The process-based solute production equation (SPM hereafter) for $C$ - $q$ derived by Maher and Chamberlain (2014) relates concentration $(C)$ to specific discharge (runoff) $(q)$ :

$$
C=\frac{C_{0}}{1+D w / q}+C_{\max } \frac{D w / q}{1+D w / q}
$$

where $D w[\mathrm{~m} / \mathrm{yr}]$ is the Damköhler coefficient, $C_{0}$ is the initial solute concentration, and $C_{\max }$ is the maximum theoretical solute concentration, thought to be set by equilibrium among the primary and secondary mineral assemblages (Maher, 2010, 2011). A higher $D w$ value reflects more efficient generation of solutes and a system more resistant to 
dilution (Maher and Chamberlain, 2014). $C_{0}$ is the initial solute concentration, derived from atmospheric deposition and/or hydrothermal or deep groundwater inputs and is independent of discharge. Equation 2 can be simplified if $C_{0}$ can be assumed to be zero (Maher and Chamberlain, 2014):

$$
C=C_{\max } \frac{D w / q}{1+D w / q}
$$

From equations (2) and (3), the fitted $C-q$ relationships parameters from long-term monitoring are $D w, C_{\max }$ and $C_{0}$.

Following our previous work (Ibarra et al., 2016), we only report $C$ - $q$ relationships with statistically significant parameter fits $(\mathrm{p}<0.05)$ and $>20 C-q$ pairs/river (Table S1). To fit both the PLM (equation 1) and the SPM (equations 2 and 3) we apply a non-linear least squares method to derive the fitted parameter values using a GaussNewton algorithm ['nls2' R package; Grothendieck (2013)]. If the $b$-value derived using equation 1 is insignificant $(b=0)$ the $C$ - $q$ relationships is assumed to be chemostatic (e.g., Godsey et al., 2009), and we do not fit the SPM. We fit equation 2 for the SPM and use equation 3 if the $C_{0}$ value derived from equation is statistically insignificant or less than zero $\left(\mathrm{C}_{0} \leq 0\right)$. Finally, we calculate $D w$ values, denoted hereafter as $D w_{\text {avg }}$, using average $C-q$ pair datasets (Moon et al., 2014; Gaillardet et al., 1999) for each individual river by rearranging equation (3) and assuming $C_{\max }$ values as the $95^{\text {th }}$ percentile for each weathering solute following methods used in von Blanckenburg et al. (2015) and Ibarra et al. (2016). Note that in Ibarra et al. (2016) the discharge-weighted mean concentrations were used, rather than arithmetic mean concentrations as used in von Blanckenburg et al. (2015), although the results presented below are not influenced by this assumption. 


\subsubsection{Results and Discussion}

Here we report the results of fitting $C-q$ relationships using time-series data, and compare these results to those derived from average $C-q$ pairs (Table S1; Figure 2). Following this, we directly compare $C-q$ fit dilution parameters, SPM $D w$ values with PLM $b$-values.

\section{Distributions of fitted dilution parameters}

The distributions reported in Table S1 are comparable in magnitude and range to those derived for small granite catchments in Ibarra et al. (2016). Further, the distribution in $b$-values and magnitude of higher $b$-values for $\mathrm{SiO}_{2}(\mathrm{aq})$ corroborates the results of Moon et al. (2014) using this same dataset, and demonstrates a much wider range of $b$-values observed for global rivers here compared to the 59 small US catchments analyzed in Godsey et al. (2009). Slopes of the PLM fits were mostly negative, indicating dilution, with some $b$-values near zero. $\mathrm{SiO}_{2}(\mathrm{aq})$ displayed $b$-values close to chemostatic with the corresponding highest $D w$ values. $\mathrm{Na}^{*}$ displayed the lowest $b$-values, however $\mathrm{HCO}_{3}{ }^{-}$displayed the lowest $D w$ values.

Comparison of $D w$ values derived here to those using average $C-q$ pairs $\left(D w_{\text {avg }}\right)$ is substantially different. We find that the median $D w$, when considering all solutes evaluated, is 6.2 times greater using the $C-q$ fits than using average $C-q$ pairs for the Gaillardet et al. (1999) dataset, and 9.8 times greater for the Moon et al. (2014) average dataset (Figure 2B). This appears to be because averaging the concentrations (Figure 1) results in $C-q$ pair values lower (in concentration and runoff) than the SPM fit, giving a 
lower $D w_{\text {avg }}$ value. In Figure 2A, we show that this is the case for a majority of catchments (all but 3 catchments with significant fits), and can results in a bias up to 100 fold in some cases. An additional bias is that this method assumes a global $C_{\max }$ value for each solute rather than variable $C_{\max }$ values for each individual river, which likely change with soil $p \mathrm{CO}_{2}$, lithology, and other geomorphic and catchment properties ( $c f$. Maher, 2011; Ibarra et al., 2016).

\section{Relationship between $b$ values and Damkohler coefficients}

In Figure 2C, we cross plot all $C-q$ fit-derived Damköhler coefficients $(D w)$ with power law $b$-values. We find that both parameters increase as $b$-values asymptote to chemostatic values (note that $\mathrm{Dw}$ values cannot be calculated for chemostatic catchments). This asymptotic behavior suggests that the form of equation 3 , when equated to equation 1, results in an inversely proportional relationship. Broadly this relationship would take the form $b=-k / D w$, where, based on the data, the constant of proportionality $(k)$, is less than 1 among the data presented here (grey contours in Figure 2C). As $b$-values approach complete dilution ( $b=-1$, note that we found no $b$-values less than -0.7) the relationship with $D w$ follows $k$ value contours of 0.1 to 0.3 .

This analysis demonstrates the fundamental difference between fitting the PLM compared to the SPM derived by Maher and Chamberlain (2014). A dilution relationship with a $b$-value between -1 and 0 is exclusively convex up in $C-q$ space (dashed grey lines in Figure 1); however, because of the lack of further fitted parameters when fitting a power law relationship there is no turnover and plateau at lower runoff (e.g., Figure 1A). In contrast, the functional form of the SPM allows for both a convex down relationship at 
low runoff and a convex up relationship at high dilution. This difference in the form of these relationships results in increasing spread among the dilution parameters ( $b$-values and $D w$ values) closer to chemostatic behavior (Figure 2C). This may be due to different carbonate vs. silicate weathering contributions (e.g., Moon et al., 2014) and/or seasonal mixing from different sources (e.g., Torres et al., 2017) during baseflow compared to peak flow regimes.

\subsubsection{Conclusion}

This study provides the first comparison between process-based modeling framework derived by Maher and Chamberlain (2014) and the traditionally used powerlaw relationship. We propose an inversely proportional relationship between the solute production dilution parameter and power-law $b$-values that converge at near chemostatic relationships. In addition, we demonstrate that using average C-q pairs results in an underestimate in the SPM dilution parameter $(D w)$. These results demonstrate the value and necessity for time-series sampling of global rivers to better constrain the functional relationships that couple weathering rates and climate.

\subsubsection{Acknowledgements}

Daniel E. Ibarra is partially supported by a Stanford EDGE-STEM Fellowship. This work was initiated under NSF EAR-1254156 to Kate Maher and was also supported by the California Alliance Research Exchange NSF HRD-1306595 to C. Page Chamberlain. 


\subsubsection{References}

Bluth GJS, Kump LR (1994) Lithologic and climatologic controls of river chemistry. Geochim Cosmochim Acta 58:2341-2359

Caves JK, Jost AB, Lau KV, Maher K (2016) Cenozoic carbon cycle imbalances and a variable weathering feedback. Earth Planet Sci Lett 450:152-163

François LM, Walker JC (1992) Modelling the Phanerozoic carbon cycle and climate: constraints from the ${ }^{87} \mathrm{Sr} /{ }^{86} \mathrm{Sr}$ isotopic ratio of seawater. Am J Sci 292:81-135

Gaillardet J, Dupré B, Louvat P, Allegre CJ (1999) Global silicate weathering and $\mathrm{CO}_{2}$ consumption rates deduced from the chemistry of large rivers. Chem Geol 159:330

Godsey SE, Kirchner JW, Clow DW (2009) Concentration-discharge relationships reflect chemostatic characteristics of US catchments. Hydrol Process 23:18441864

Grothendieck G (2013) nls2: non-linear regression with brute force. R package version 0.2. https://CRAN.R-project.org/package=nls2

Ibarra DE, Caves JK, Moon S et al (2016) Differential weathering of basaltic and granitic catchments from concentration-discharge relationships. Geochim Cosmochim Acta 190:265-293

Kump LR, Arthur MA (1997) Global chemical erosion during the cenozoic: weatherability balances the budgets. Tectonic uplift and climate change. Springer, Boston, pp 399-426

Kump LR, Brantley SL, Arthur MA (2000) Chemical weathering, atmospheric $\mathrm{CO}_{2}$, and climate. Annu Rev Earth Planet Sci 28:611-667 
Maher K (2010) The dependence of chemical weathering rates on fluid residence time. Earth Planet Sci Lett 294:101-110

Maher K (2011) The role of fluid residence time and topographic scales in determining chemical fluxes from landscapes. Earth Planet Sci Lett 312:48-58

Maher K, Chamberlain CP (2014) Hydrologic regulation of chemical weathering and the geologic. Science 343:1502-1504

Moon S, Chamberlain CP, Hilley GE (2014) New estimates of silicate weathering rates and their uncertainties in global rivers. Geochim Cosmochim Acta 134:257-274

Torres MA, West AJ, Clark KE (2015) Geomorphic regime modulates hydrologic control of chemical weathering in the Andes-Amazon. Geochim Cosmochim Acta $166: 105-128$

Torres MA, Baronas JJ, Clarke KE, Feakins SJ, West AJ (2017) Mixing as a driver of temporal variations in river hydrochemistry. Part 1: insights from conservative traces in the Andes-Amazon transition. Water Resour Res 53:3102-3119

von Blanckenburg F, Bouchez J, Ibarra DE, Maher K (2015) Stable runoff and weathering fluxes into the oceans over Quaternary climate cycles. Nat Geosci $8: 538-542$ 


\subsubsection{Figures}

Figure 1. Example $C-q$ fits for two global rivers. (A) $\mathrm{HCO}_{3}{ }^{-}$vs. runoff from the Narmada River. (B) $\mathrm{Ca}^{2+}$ vs. runoff from the Pechora River. Solid lines are the SPM fits and dashed lines are the PLM fits. Large grey dots are the mean runoff and dischargeweighted mean concentration.
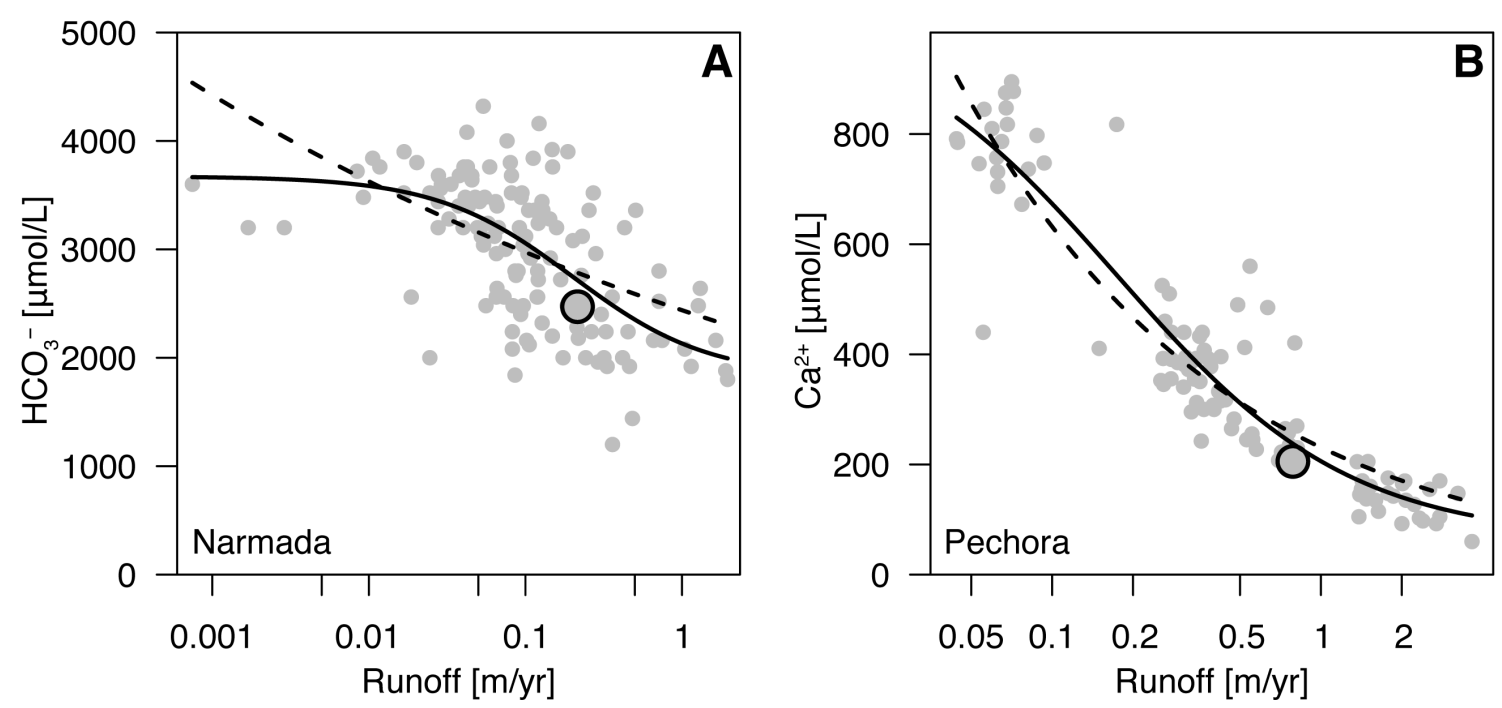
Figure 2 (next page). (A) $D w_{\text {avg }}$ values compared to $D w$ values (Figure 1) using the dataset from Moon et al. (2014). Both axes are log-scale. Grey lines indicate factor of 10 and 100 envelopes around the 1:1 line (bold). Errors are the standard error of the

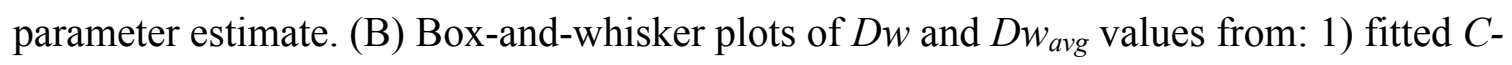
$q$ relationships (Figure 1); 2) average C-q pairs from Moon et al. (2014); and 3) average $C-q$ pairs from Gaillardet et al. (1999). Thick grey lines are the median value for each dataset (see text for values). (C) $D w$ values versus power law $b$-values. Errors are the standard error of the parameter estimates. Grey contours are for a general inversely proportional relationship $b=k /-D w$ for different scaling values of $k$. (D) Same as (B) for power law $b$-values using only fitted $C-q$ relationships. 

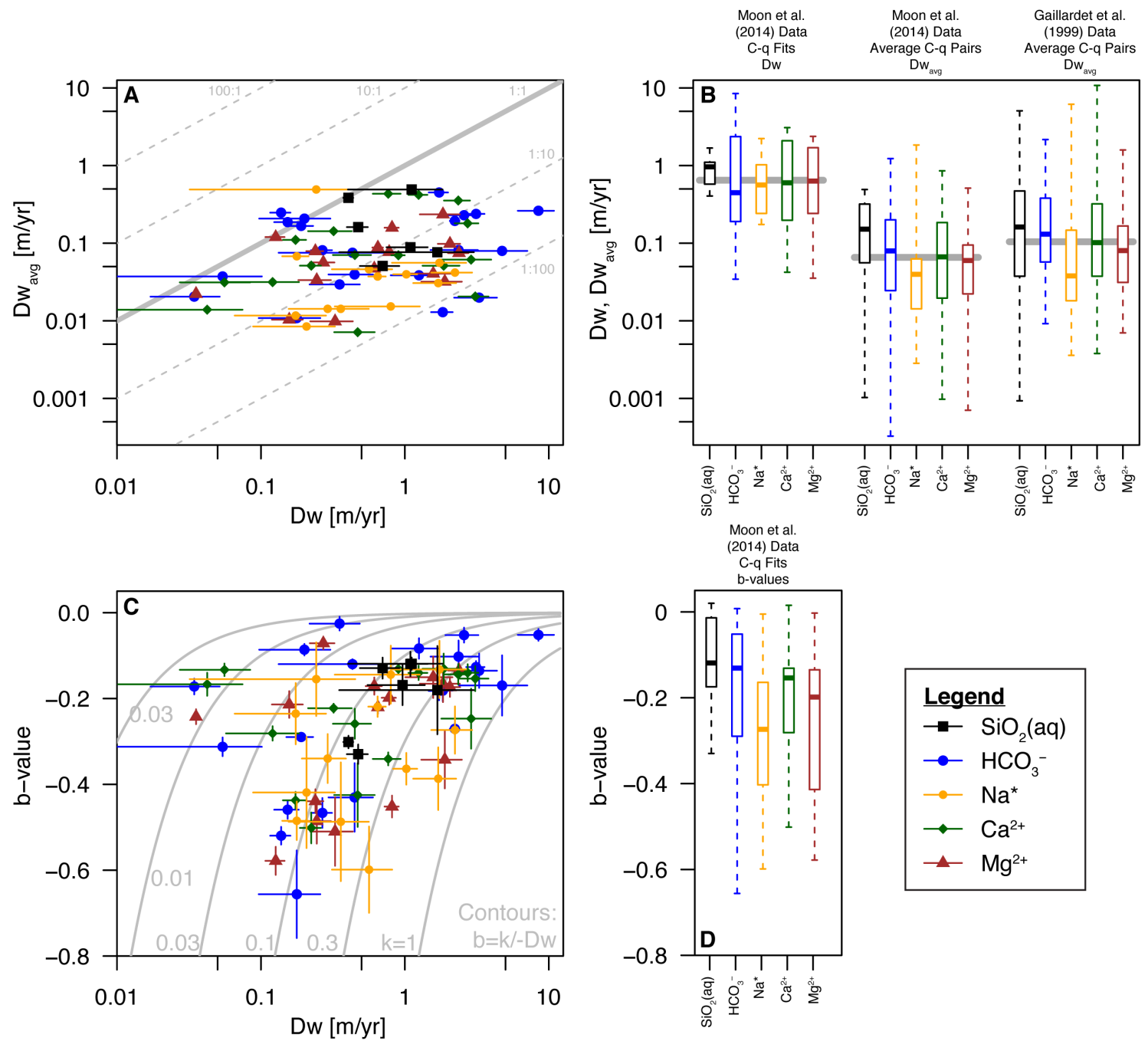


\section{APPENDICES}

\section{APPENDIX A}

\section{Supplemental Figures for Chapter 1}

Figure A1 (next page). Schematic of HyBIM model structure. The model structure uses a matrix inversion to solve a system of three equations $\left(x=\mathbf{A}^{-1} b\right)$ implemented at each time step to calculate changes in lake volume (from the combined evaporation and inputs) and basin average air temperature. After smoothing and interpolating to an even time series, the input dataset (time series of $\delta^{18} \mathrm{O}, \mathrm{Mg} / \mathrm{Ca}$ and $\mathrm{Sr} / \mathrm{Ca}$ from biogenic carbonate), given a set of adjustable input parameters (right side of the fig.; table 1), is first placed in lake water composition $\left(\delta^{18} \mathrm{O},[\mathrm{Mg}]\right.$ and $[\mathrm{Sr}]$ Lake Water $)$. The first derivative of the lake water time series is inputted as the b vector at each time step $\left(\mathrm{d}\left(\delta^{18} \mathrm{O}\right), \mathrm{d}[\mathrm{Mg}]\right.$ and $\left.\mathrm{d}[\mathrm{Sr}]\right)$. The partial derivatives that make up the $\mathbf{A}$ matrix are substituted at each time step using mixing equations and evaporation equations (eqs 5 to 9 for $\mathrm{F}_{\text {evap }}$ and $\mathrm{F}_{\text {input }}$ derivatives), or estimated for temperature (the $\mathrm{T}$ derivatives) based on the geographic location (see text for details). For each Monte Carlo iteration the model produces a time series of the x solution vector. To provide summary statistics after combining the evaporation and lake input variables to calculate changes in volume we calculate the median and 95\% range (as in figs. 3 and 4). 
Input Dataset

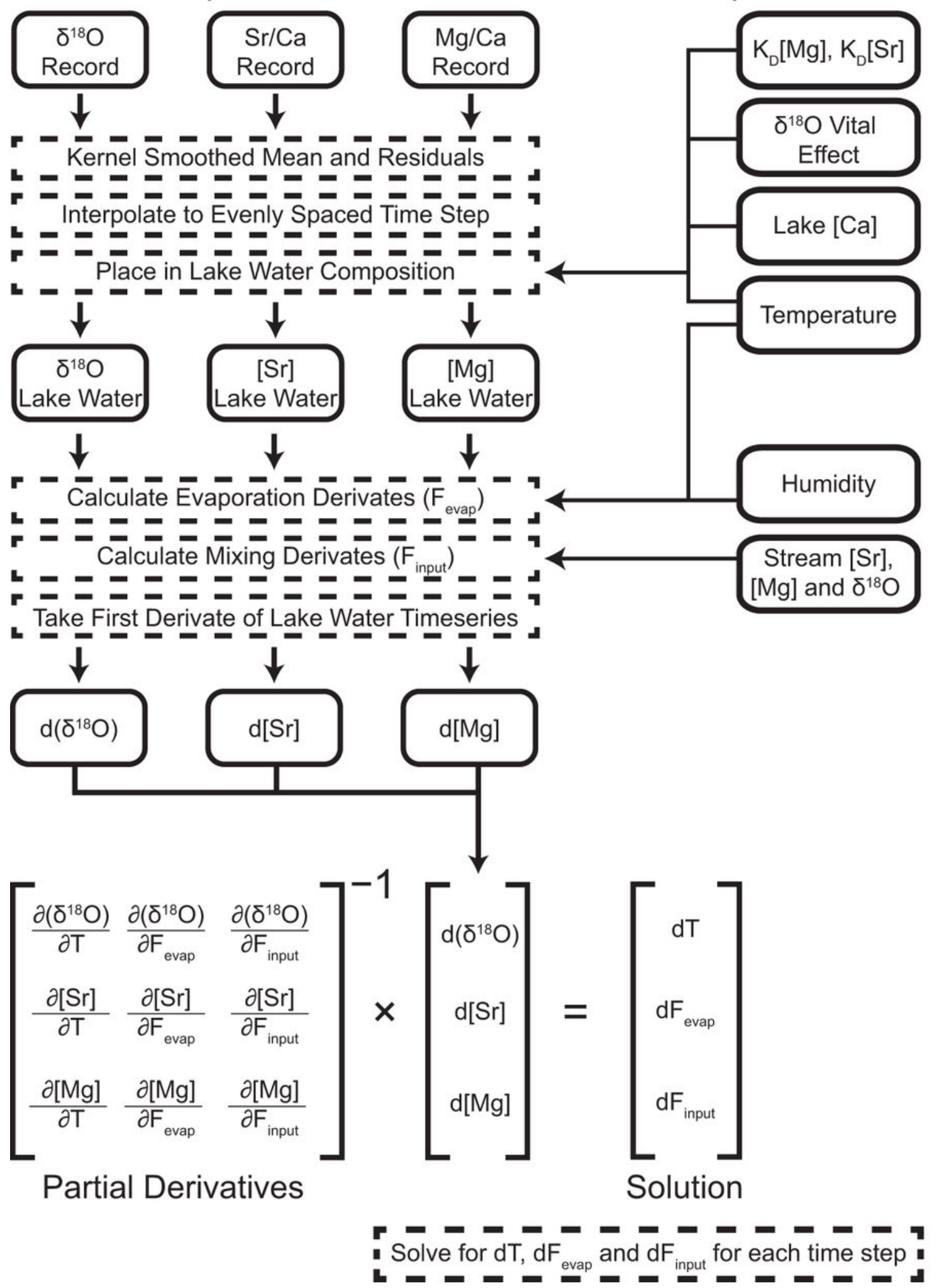


Figure A2. Annual weighted precipitation $\delta^{18} \mathrm{O}$ and mean annual temperature from the Global Network in Precipitation Data (GNIP) as compiled by the Stable Water Isotope Intercomparison Group (SWING). Following Rozanski and other (1993) we calculate slope of the temperature vs. weighted precipitation $\delta^{18} \mathrm{O}$ for the mid and high latitude ( $>$ $23^{\circ}$ ) sites (gray), and tropics (black). We only use the empirical regression (slope and uncertainty) for the tropics in modeling of Lake Miragoane temperature changes. For the Songliao Basin we use the original regression of Rozanski and others (1993) of $0.58 \% /{ }^{\circ} \mathrm{C}$.

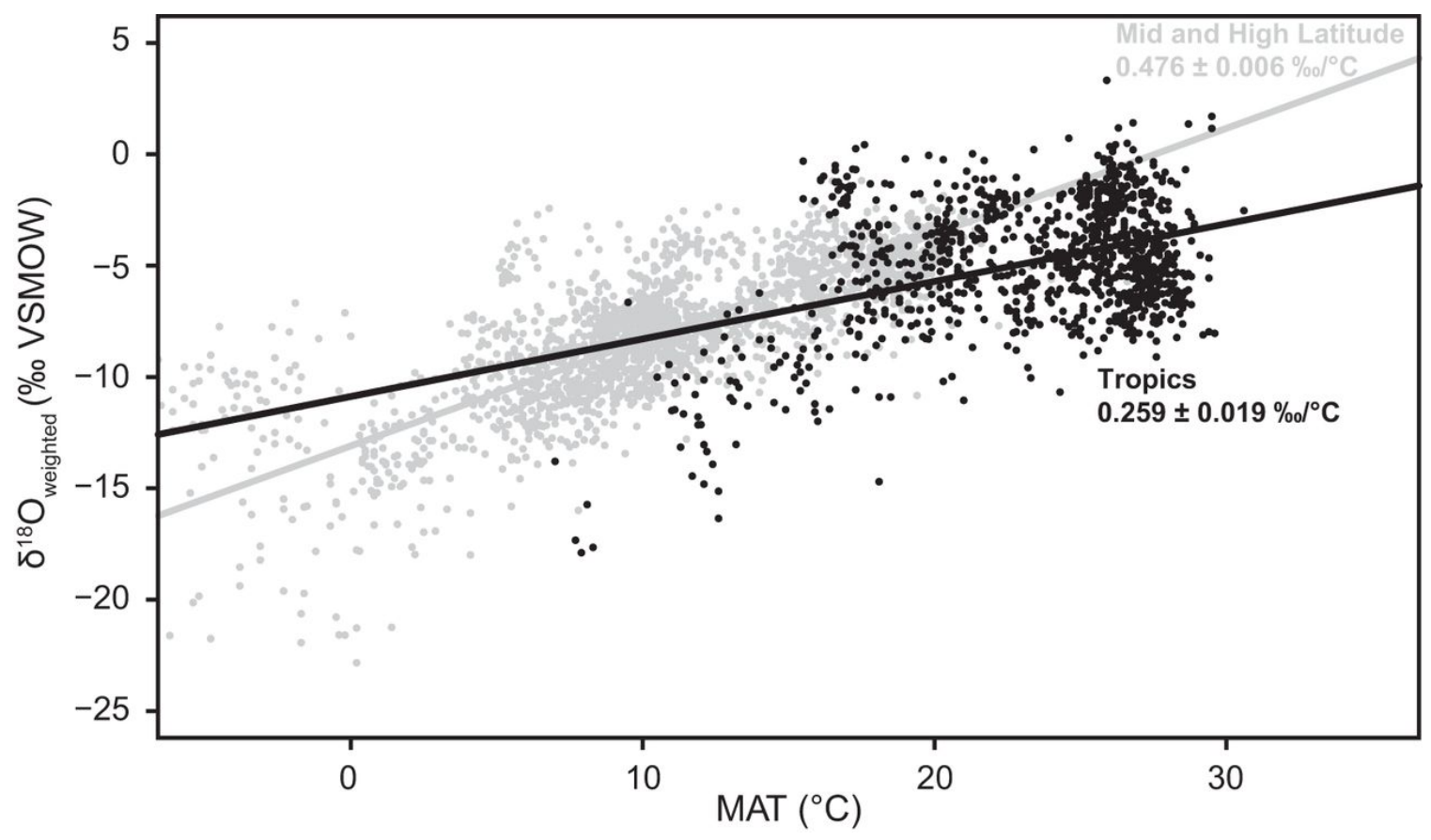




\section{APPENDIX B \\ Supplemental Text, Figures and Tables for Chapter 2}

Date Repository Contents:

- Scaling of potential evapotranspiration with surface temperature

- Processing of climate model output and NARR dataset

- Dataset Treatment

- $\quad$ Figures DR1-DR3

- Links to databases used for this study

- Tables DR1-DR5

- DR References

\section{Scaling of potential evapotranspiration with surface temperature}

We use climate model experiments to estimate how net surface radiation $\left(\mathrm{R}_{\mathrm{N}}\right)$ and potential evapotranspiration $\left(\mathrm{E}_{\mathrm{p}}\right)$ scale with temperature (Equation 4$)$. To do so we sum the radiation fluxes (Equation 4$)$ to obtain the annual net surface radiation $\left(\mathrm{R}_{\mathrm{N}}\right)$ and calculate average annual temperature for all land grid cells in our domain of interest (30$\left.45^{\circ} \mathrm{N}, 102-121^{\circ} \mathrm{W}\right)$. We then calculate domain average temperature and $\mathrm{R}_{\mathrm{N}}$ anomalies for the LGM and Pliocene using the PMIP3 and PlioMIP output (Table DR5) relative to the preindustrial control experiments (see next section). We also include 25 CMIP5 climate models using 30-year averages from the historical (1976-2005) and RCP 8.5 (2070-2099) simulations (where the historical period is taken as the control point). The $\mathrm{R}_{\mathrm{N}}$ anomalies are calculated as a percentage change relative to the control. 
The potential evapotranspiration calculated from the net surface radiation scales with surface temperature at a rate of $1.6 \% / \mathrm{K}$ (Figure DR1). For this study we use the netradiation formulation of potential evapotranspiration (Roderick et al., 2014) and thus use the scaling factor of $1.6 \% / \mathrm{K}$ for the NARR sensitivity analyses. This regional result derived using the CMIP5, PMIP3 and PlioMIP models is similar to previous work using CMIP3 and CMIP5 models which suggest empirical scalings of $\mathrm{R}_{\mathrm{N}}$ to temperature of $\sim 0.9$ to $1.5 \% / \mathrm{K}$ (Milly and Dunne, 2016; Scheff and Frierson, 2014; Roderick et al., 2014; 2015).

\section{Processing of climate model output and NARR dataset}

To carry out our lake area modeling (Equations 2 and 3), we use monthly average output from the North American Regional Reanalysis (NARR) (Mesinger et al., 2006), the Paleoclimate Model Intercomparison Project 3 (PMIP3) ensemble and the Pliocene Model Intercomparison Project (PlioMIP) ensemble (Braconnot et al., 2012; Haywood et al., 2011; 2013). PlioMIP conducted two distinct simulations; we choose to use Experiment 2, which is the full ocean-atmosphere climate model simulations of the midPliocene ( $c f$. Haywood et al., 2013), making them more directly comparable to the LGM model output from PMIP3. We only use the archived energy and precipitation fields for forward modeling lake area distributions (Equation 2), and follow Roderick et al. (2014) by also using evapotranspiration (ET) fields to derive estimates of the regional $\omega$ parameters used in the Budyko equation (Equation 3). The models used in this study (Table DR4) are a subset of the PMIP3 and PlioMIP ensembles that included all of the necessary surface energy and water flux variables necessary to carry out our calculations. 
Because of different model resolutions we re-grid all model data prior to further analysis using the 'fields' package in R (Nycha et al. 2016).

We use the methods outlined by Roderick et al. (2014) and process the NARR and climate model output by calculating the annual sum of potential evapotranspiration $\left(E_{p}\right)$ as the liquid water equivalent of the net irradiance (Equation 4 in main text). Further, annually summed precipitation (P) and evapotranspiration were tabulated from monthly averages. We use all of the land-grid cells where ET does not exceed P annually to fit the Budyko relationship (Equation 3 in main text) using the 'nls2' package in $\mathrm{R}$ (Grothendieck, 2013). The derived $\omega$ values are reported in Table DR5. The median change in $\mathrm{E}_{\mathrm{p}} / \mathrm{P}$ vs. ET/P for all grid cells in the domain for each model is shown in Figure DR2 with the mean $\omega$ value over all models contoured. We plot the median change of $\mathrm{E}_{\mathrm{p}} / \mathrm{P}$ vs. ET/P, rather than mean changes, for each individual model because the spatial distributions of $\mathrm{E}_{\mathrm{p}}, \mathrm{P}$ and $\mathrm{ET}$ are skewed in the modeling domain of interest. To avoid potential biases in absolute precipitation amount simulated by different models, we plot the anomaly relative to the pre-industrial control simulation in the predicted lake surface area change in Figure 2B rather than the absolute value. Further, since our objective is to model trends and lake area distributions, we determine $\mathrm{E}_{\mathrm{L}}$ using the Priestley-Taylor equation (Priestley, 1959; Priestley and Taylor, 1972; Sumner and Jacobs, 2005):

$$
L E=\alpha \frac{\Delta}{\Delta+\gamma} \boldsymbol{R}_{N}
$$

(DR1) 
where $\mathrm{LE}$ is the latent heat flux that is related to lake evaporation $\left(\mathrm{E}_{\mathrm{L}}\right.$ in equation 3 in the main text) by the latent heat of vaporization, $\alpha=1.25$ is an empirically determined dimensionless correction, $\Delta$ is the slope of the saturation vapor-pressure curve, which is temperature dependent, $\gamma$ is the psychometric constant, which is elevation dependent, and $\mathrm{R}_{\mathrm{N}}$ is the net downward radiation at the surface (see equation 4). Use of more complex evaporation equations would require additional parameters that are difficult to estimate or measure in the past (e.g., Linacre, 1977).

To carry out the NARR sensitivity analyses (Figure 2A, 2C, 2D and DR3), we scale precipitation linearly using a scaling factor as described in the main text. Temperature is scaled linearly to scale $\mathrm{R}_{\mathrm{N}}$ (equation 4 ) by $1.6 \% / \mathrm{K}$ (see previous section). Further, because we use the Priestley-Taylor equation (Priestley, 1959; Priestley and Taylor, 1972; Sumner and Jacobs, 2005) to approximate lake evaporation ( $\mathrm{E}_{\mathrm{L}}$ in equation 2 in the main text) changes in temperature change the slope $(\Delta)$ of the saturation vaporpressure curve. For the NARR sensitivity analyses, we use the US catchment median value of $\omega=2.6$ (Greve et al., 2015). If we were to use a lower $\omega$ value (see for example PMIP3/PlioMIP control simulations in Table DR5), as suggested by maps of modern catchment derived $\omega$ values in Greve et al. (2015), the effect of decreasing evaporative demand on increasing LGM lake levels would be greater, suggesting lower precipitation scaling factors (Figure 2C and 2D). Conversely, the increase in precipitation needed to drive Pliocene lake areas would be lower, but greater than pre-industrial. However, a majority of the models suggest a decrease in $\omega$ for the LGM but not the Pliocene (Table DR5). 


\section{Dataset Treatment}

LGM Normalized Lake Areas. LGM lake areas were compiled from the tables and maps of the sources listed in Table DR1 (Allen, 2005; Reheis, 1999; Orme, 2008; Grayson, 2011; Natural Earth database; Soller et al., 2009; Williams and Bedinger, 1984; Mifflin and Wheat, 1979). We assume no major watershed boundary and basin configuration changes since the LGM. We paired the lake areas in ArcGIS 10.0 with the LGM lake areas with modern watershed boundaries from the HydroSHEDS, HydroBASINS, and HydroLAKES (Lehner et al., 2008; Lehner and Grill, 2013; Messager et al., 2016) databases (http://www.hydrosheds.org/). Further assumptions were:

- Average normalized areas were calculated across all available estimates (rightmost column of Table DR1).

- For Figure DR3 northern Great Basin lakes $\left(>39^{\circ} \mathrm{N}\right)$ areas were reduced by $50 \%$, based on work from smaller lakes such as Lake Surprise (Ibarra et al., 2014), Lake Franklin (Munroe and Laabs, 2013), and a review by Reheis et al. (2014).

Mid-Pliocene Normalized Lake Areas. Lake areas were only derived from the compilation in Pound et al. (2014). We only paired lakes in the compilation from Pound et al. (2014) to modern drainage basins (Table DR3) if the following criteria were met:

- It was clear that the lake was terminal based on the lacustrine sedimentology, topography and drainage network (cf. Table 2 in Pound et al. (2014)). 
- The lake area did not span multiple modern watersheds over large drainage divides nor did it appear to be influenced by large tectonic drainage reconfigurations (cf. Adam et al., 1990; Thompson, 1992; Reheis et al., 2002; Knott et al., 2008; Phillips, 2008; Pound et al., 2014).

Given that extension in the Basin and Range has been ongoing since the Miocene (e.g., Colgan et al., 2006), it is likely that the many terminal basins created by Basin and Range faulting were filled by lakes during wet intervals such as the mid-Pliocene. Since the Pound et al. (2014) dataset is primarily derived from basinal sedimentary deposits, which may have undergone unquantifiable erosion or burial since Pliocene deposition the $A_{L} / A_{B}$ calculations may be underestimates which would necessitate even larger increases in precipitation relative to present day during the mid-Pliocene. However, if additional extension has occurred since the Pliocene these estimates may be overestimates. Examples of lakes in Table DR 3 from the Pound et al. (2014) compilation for which normalized lake areas were not calculated include Tule Lake (Adam et al., 1990), which has evidence for a sill indicating that the lake overflowed into the Klamath River basin (cf. Figure 1 of Adam et al., (1990)), and Glenn's Ferry (Smith, 1981; Thompson, 1992), due to possible drainage to the southwest (Thompson, 1992).

Macrostrat lacustrine data are only used as supporting evidence plotted on Figure 1B. The Macrostrat database does not provide individual lakes, rather the database contains aggregates of stratigraphic datasets grouped into polygons of differing areas. However, given the relatively high resolution of the Macrostrat polygons the distribution of mid-Pliocene lacustrine sediments suggests that many areas of modern terminally draining basins had lakes during the mid-Pliocene (Fig. 1B). 
The calculation of lake area, $A_{L}$ represents the maximum expansion of lakes in a given basin during the time intervals of interest. A complication for both the LGM and mid-Pliocene lake areas is the "Manly Group", which contain multiple higher elevation fill and spill sub-basins that eventually flowed to Lake Manly (Death Valley). For ease of analysis we choose to group these sub-basins into one large terminal basin (see Table DR1 and DR3) although this treatment may result in an underestimate in $A_{L} / A_{B}$. Similarly, Lake Lahontan and Lake Bonneville integrated multiple sub-basins but were fully connected at their highstand elevations (Reheis et al., 2014). As such, we combined areas for all sub-basins in the Lahontan and Bonneville watersheds in Table DR1.

Temperature Estimates. Independent estimates of temperature changes (relative to modern) (x-axis of Figures 2C, 2D and DR3) are as follows:

- Figure 2C we plot the full range of temperature estimates for the LGM (-13 to $2.75^{\circ} \mathrm{C}\left(\right.$ median $\left.=-7.5^{\circ} \mathrm{C}\right)$ based on tables in: Matsubara and Howard, 2008; Grayson, 2011).

- In Figure 2D depressions are observed to be less depressed in this region than further inland. Thus, we plot a reduced range of temperature estimates for the LGM ( -10 to $-2.75^{\circ} \mathrm{C}$ based on tables in: Matsubara and Howard, 2008; Grayson, 2011).

- For Figures 2C and 2D we plot the full range of temperature estimates for the mid-Pliocene $\left(0\right.$ to $+6^{\circ} \mathrm{C}$ based on tables in: Dowsett et al., 1994; Molnar and Cane, 2007) 
Figure DR1. Empirical scaling of potential evapotranspiration with surface temperature based on PMIP3, PlioMIP and CMIP5 simulations (see DR text above).

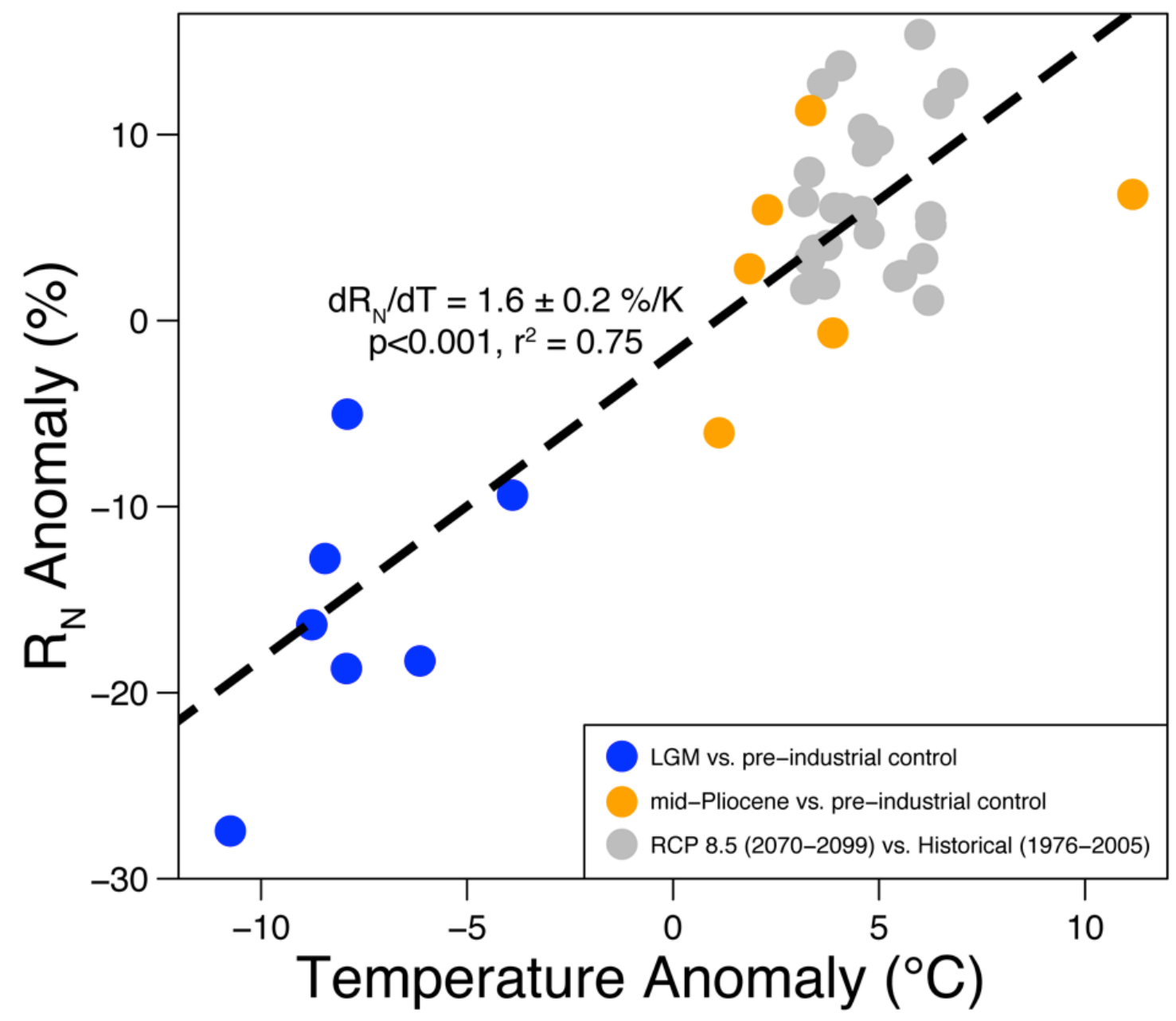


Figure DR2. A: Budyko framework - median changes in $\mathrm{E}_{\mathrm{p}} / \mathrm{P}$ vs. ET/P calculated from LGM climate model simulations. Dashed lines connect simulations from the same models. Colored curves and symbols are the LGM simulations. Solid lines are the ensemble averages (Table DR5). See climate model processing methods for more details. B: Same as A for mid-Pliocene simulations.

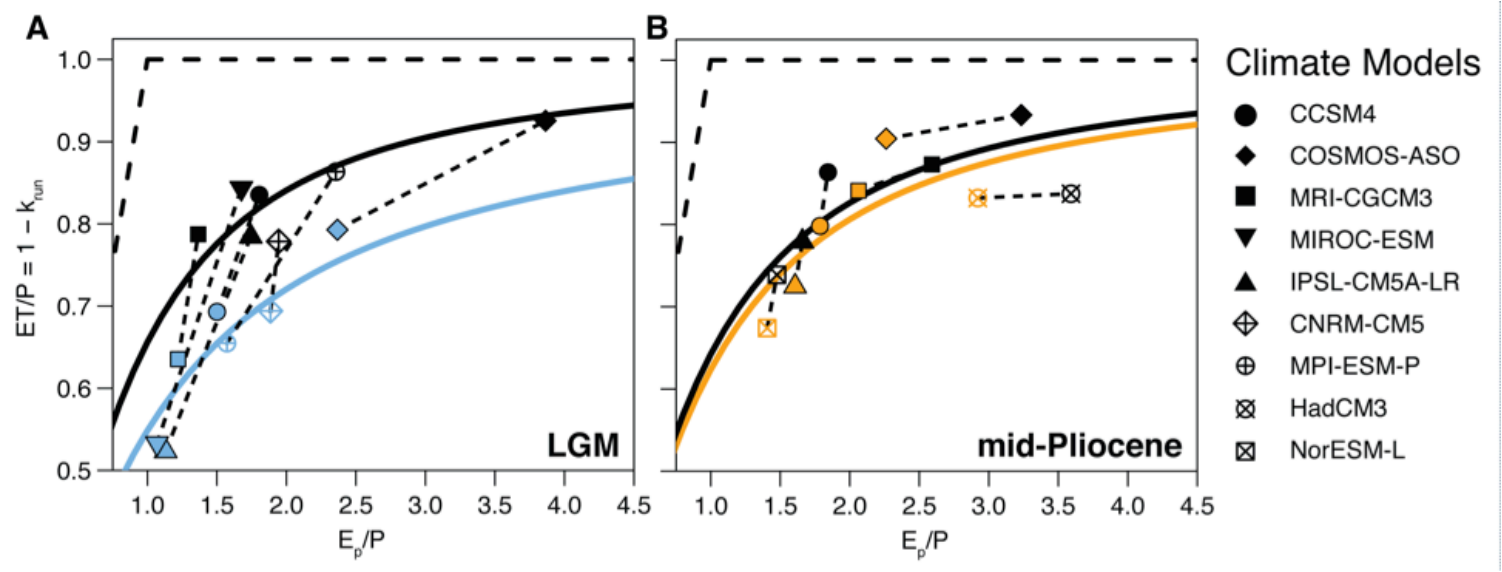


Figure DR3 (next page). Effect of adjusting northern Great Basin lake areas. Median calculated lake level from NARR data (black lines) and original LGM distributions (blue shading and lines) are the same as Figure 2C. Shown in red is the adjusted distribution of LGM lake areas (see Table DR1) assuming 50\% smaller lakes in the northern Great Basin (lakes north of $39^{\circ} \mathrm{N}$ ). Many lakes in the northern Great Basin stood at prominent but lower stillstands during the LGM than the post-LGM highstands (Munroe and Laabs, 2013; Ibarra et al., 2014; Reheis et al., 2014). As in Figure 2B we plot the full range of temperature estimates for the $\operatorname{LGM}\left(-13\right.$ to $-2.75^{\circ} \mathrm{C}\left(\right.$ median $\left.=-7.5^{\circ} \mathrm{C}\right)$ based on tables in: Matsubara and Howard, 2008; Grayson, 2011). 


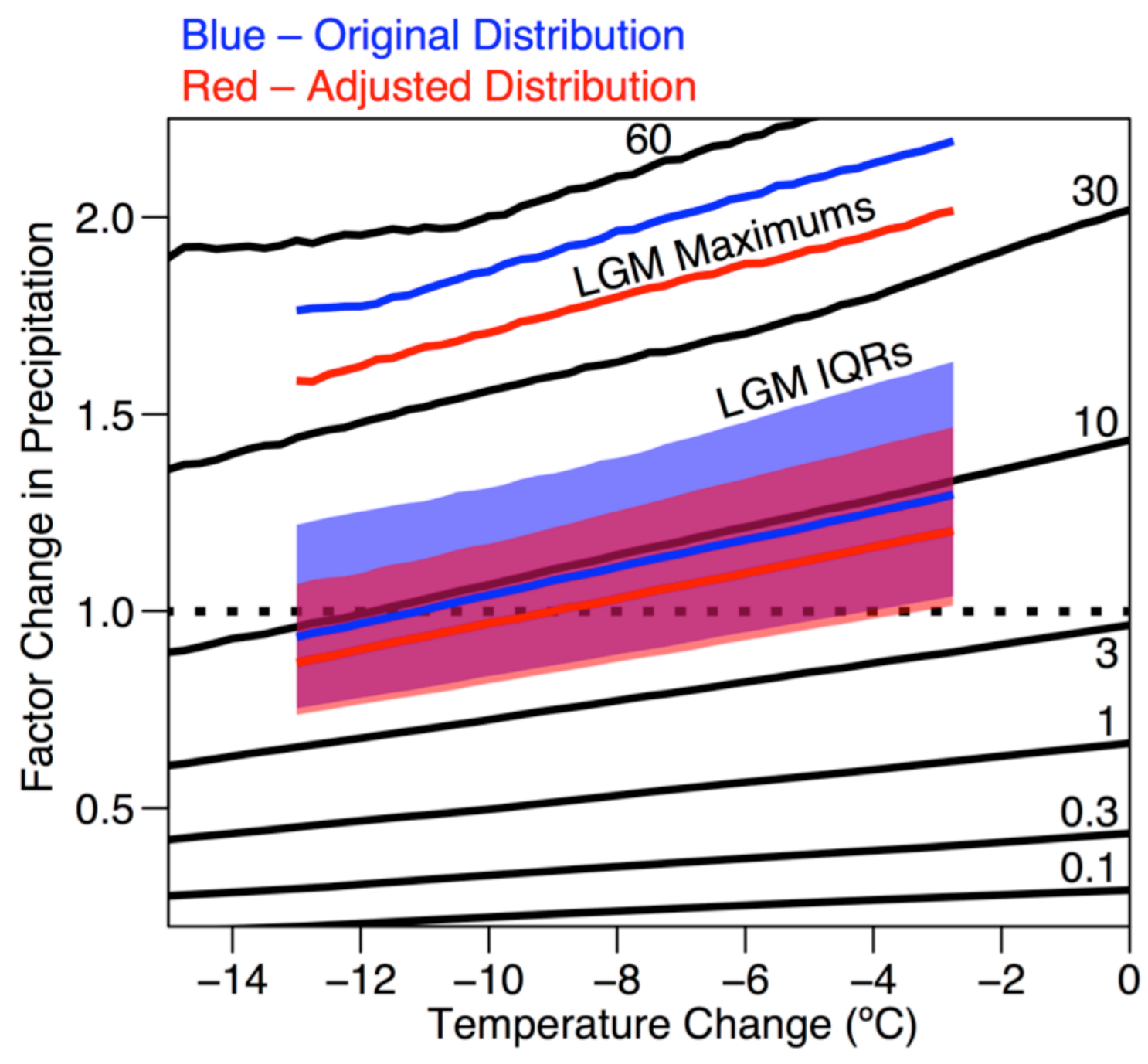




\section{Links to online databases for geospatial and climate data used for this study}

- HydroSHEDS/HydroBASINS/HydroLAKES (Lehner et al., 2008; Lehner and Grill, 2013; Messager et al., 2016): http://www.hydrosheds.org/

- Natural Earth pluvial lakes database: http://www.naturalearthdata.com/downloads/10m-physical-vectors/10m-lakes/

- Macrostrat database: https://macrostrat.org/

- "Extent of Pleistocene Lakes in the Western Great Basin", by Reheis (1999): https://geo-nsdi.er.usgs.gov/metadata/map-mf/2323/metadata.faq.html

- "Map Database for Surficial Materials in the Coterminous United States", by Soller et al. (2009): https://pubs.usgs.gov/ds/425/

- NCEP North American Regional Reanalysis (NARR): https://www.esrl.noaa.gov/psd/data/gridded/data.narr.html

- Paleoclimate Modelling Intercomparison Project 3 (PMIP3): https://pmip3.1sce.ipsl.fr/

- PlioMIP1 output was distributed by Alan Haywood, Aislin Dolan, Daniel Hill and Steven Pickering (personal communication, 2016) 
Table DR1 (next page) - Compilation of late Pleistocene ( $\sim$ LGM) lake areas and modern watershed areas. All areas are in km ${ }^{2}$. References: (1) HydroSHEDS/HydroBASINS/HydroLAKES (Lehner et al., 2008; Lehner and Grill, 2013; Messager et al., 2016), (2) Allen (2005), (3) Reheis (1999), (4) Orme (2008), (5) Grayson (2011), (6) Natural Earth database, (7) Soller et al. (2009), (8) Williams and Bedinger (1984), (9) Mifflin and Wheat (1979). Average normalized areas are calculated using the HydroBASINS (Lehner and Grill, 2013) basin areas and stream networks with all available lake area estimates (columns 2b, 3a, 4-9). Agreement of lake areas between publications is $<5 \%$ for most basins. Allen (2005) basin areas (column 2a) are for comparison only. Reheis (1999) maximum lake areas (column 3b) are not used as they represent post-LGM highstand areas or pre-MIS 2 highstands. Latitude and longitude values are for reference only and correspond to the centroid for each terminal basin. Soller et al. (2009), Reheis (1999) and the Natural Earth pluvial lakes database are mapped in Figure 1A. Adjusted normalized distributions (shown used in Figure DR3) assumes that LGM lake areas were $\sim 50 \%$ maximum highstands for watersheds north of $39^{\circ} \mathrm{N}$ (polygon centroid's location) to account for post-LGM highstands observed in the northern Great Basin (Munroe and Laabs, 2013; Ibarra et al., 2014; Reheis et al., 2014). Unnamed basins were assigned numbers: UN-GB\# - Unnamed-Great Basin; UN-SW\# - Unnamed-Southwest. 


\begin{tabular}{|c|c|c|c|c|c|c|c|c|c|c|c|c|c|c|}
\hline $\begin{array}{l}\text { Lake } \\
\text { Name } \\
\end{array}$ & Latitude & Longitude & $\begin{array}{c}\text { Basin } \\
\text { Area (1) } \\
\end{array}$ & $\begin{array}{c}\text { Basin } \\
\text { Area } \\
\text { (2a) } \\
\end{array}$ & $\begin{array}{l}\text { Lake } \\
\text { Area } \\
(2 b) \\
\end{array}$ & $\begin{array}{c}\text { Lake } \\
\text { Area } \\
(3 a)\end{array}$ & $\begin{array}{c}\text { Maximum } \\
\text { Lake } \\
\text { Area (3b) }\end{array}$ & $\begin{array}{c}\text { Lake } \\
\text { Area (4) }\end{array}$ & $\begin{array}{c}\text { Lake } \\
\text { Area (5) } \\
\end{array}$ & $\begin{array}{c}\text { Lake } \\
\text { Area (6) } \\
\end{array}$ & $\begin{array}{c}\text { Lake } \\
\text { Area (7) } \\
\end{array}$ & $\begin{array}{c}\text { Lake } \\
\text { Area (8) } \\
\end{array}$ & $\begin{array}{c}\text { Lake } \\
\text { Area (9) }\end{array}$ & $\begin{array}{c}\text { Average } \\
\text { Normalized } \\
\text { Area }(\%)\end{array}$ \\
\hline Acme & 38.55 & -118.32 & 351.45 & & & & & & & 7.40 & & & & 2.10 \\
\hline Alford & 42.18 & -118.68 & 7031.36 & & & 1153.62 & & 1270.00 & 1269.10 & 947.19 & & 1217.30 & & 16.66 \\
\hline Alkali & 43.04 & -120.06 & 1375.20 & & & & & 550.00 & 590.52 & 565.90 & & & & 41.36 \\
\hline Animas & 32.29 & -108.85 & 5607.00 & 5670.00 & 374.00 & & & & & & 313.38 & & & 5.59 \\
\hline Antelope & 39.85 & -114.31 & 874.68 & & & 140.15 & & & 124.32 & 127.12 & & 124.32 & 124.32 & 14.64 \\
\hline Bonneville & 40.18 & -112.67 & 134131.13 & & & & & 51700.00 & 51864.55 & 51956.71 & & 51644.40 & 51644.40 & 38.59 \\
\hline $\begin{array}{l}\text { Bonnie } \\
\text { Claire }\end{array}$ & 37.33 & -117.11 & 3526.21 & & & & & & & 142.63 & & & & 4.04 \\
\hline Bristol & 37.96 & -114.76 & 2334.47 & & & & & & 90.65 & 77.33 & & 90.65 & & 3.69 \\
\hline Buffalo & 40.50 & -117.32 & 1284.38 & & & 66.55 & & & 199.43 & 195.25 & & 199.43 & & 12.86 \\
\hline Cactus Flat & 38.13 & -116.80 & 6100.73 & & & & & 344.47 & & 374.97 & & & & 5.90 \\
\hline Cahuilla & 33.00 & -115.80 & 20050.8 & & & & & & & & & 7769.97 & & 38.75 \\
\hline Carpenter & 38.51 & -114.57 & 1432.29 & & & 121.93 & & & 347.06 & 358.10 & & 347.06 & 347.06 & 21.24 \\
\hline Catlow & 42.52 & -119.20 & 4850.63 & & & & & 900.00 & 898.73 & 905.54 & & 1152.55 & & 19.88 \\
\hline Cave & 38.57 & -114.85 & 930.13 & & & 121.29 & & & 178.71 & 180.27 & & 178.71 & 178.71 & 18.01 \\
\hline Cedar & 37.62 & -113.17 & 374.57 & & & & & & & 18.55 & & & & 4.95 \\
\hline Chewaucan & 42.68 & -120.51 & 3385.35 & & & & & 1200.00 & 1243.20 & 1194.08 & & 1243.20 & & 36.04 \\
\hline Chochise & 32.15 & -109.84 & 4357.00 & & & & & & & & 545.79 & 621.60 & & 13.40 \\
\hline Clayton & 37.71 & -117.60 & 1437.76 & & & & & & & 85.14 & & & & 5.92 \\
\hline Clover & 40.85 & -114.83 & 2665.56 & & & 743.21 & 1094.25 & 890.00 & 890.96 & 913.81 & & 911.68 & 911.68 & 32.90 \\
\hline Cloverdale & 31.36 & -108.85 & 467.80 & 460.00 & 102.00 & & & & & & 82.52 & 77.70 & & 17.12 \\
\hline Coal & 38.00 & -115.41 & 2487.57 & & & & & & 178.71 & 188.33 & & 178.71 & 178.71 & 7.28 \\
\hline Colombus & 37.79 & -118.00 & 3532.12 & & & 141.45 & & & 139.86 & 365.10 & & 204.61 & 204.61 & 5.98 \\
\hline Coyote & 42.38 & -118.19 & 1789.45 & & & 317.39 & & & & 125.90 & & & & 12.39 \\
\hline Cuddeback & 35.31 & -117.47 & 555.31 & & & & & & & & & 90.65 & & 16.32 \\
\hline $\begin{array}{l}\text { Deep } \\
\text { Spring }\end{array}$ & 37.36 & -118.08 & 519.42 & & & & & & 44.03 & 25.33 & & 44.03 & & 7.28 \\
\hline Delamar & 37.44 & -114.87 & 926.74 & & & & & & & 26.49 & & & & 2.86 \\
\hline Desatoya & 39.29 & -117.57 & 1490.65 & & & 397.51 & & & 435.12 & 442.13 & & 435.12 & 435.12 & 28.78 \\
\hline Diamond & 39.40 & $\begin{array}{l}-116.38 \\
\end{array}$ & 8018.15 & & & 1021.21 & 2283.22 & 760.00 & 758.87 & 1023.04 & & 1015.28 & & 11.42 \\
\hline Dixie & 39.80 & -117.84 & 5410.24 & & & 798.63 & 2394.69 & 1090.00 & 1090.39 & 721.47 & & 714.84 & 766.64 & 15.96 \\
\hline Eagle & 40.64 & -120.89 & 1123.78 & & & 126.84 & & & 160.58 & 145.49 & & & & 12.84 \\
\hline Edwards & 39.58 & -117.69 & 1078.89 & & & 287.10 & & & 264.18 & 266.36 & & 264.18 & 264.18 & 24.95 \\
\hline Encino & 34.60 & -105.60 & 644.20 & 620.00 & 96.00 & & & & & & 56.77 & 310.80 & & 28.53 \\
\hline Estancia & 34.67 & -105.96 & 5733.70 & 5050.00 & 1125.00 & & & & & & 1084.76 & 2330.99 & & 29.79 \\
\hline Fort Rock & 43.28 & -120.89 & 6403.89 & & & & & & 1945.08 & 1564.66 & & 2343.94 & & 30.47 \\
\hline Franklin & 40.37 & -115.23 & 3345.89 & & & 947.49 & & 1220.00 & 1219.89 & 1248.19 & & 1250.97 & 1250.97 & 35.55 \\
\hline Fred & 39.77 & $\begin{array}{l}-119.82 \\
\end{array}$ & 47.73 & & & & & & & 7.90 & & & & 16.56 \\
\hline Frenchman & 36.85 & -115.96 & 1180.75 & & & & & & & 20.05 & & & & 1.70 \\
\hline Gabbs & 38.85 & -118.09 & 3319.81 & & & & & & & 312.43 & & & & 9.41 \\
\hline
\end{tabular}




\begin{tabular}{|c|c|c|c|c|c|c|c|c|c|c|c|c|c|c|}
\hline Gale & 39.83 & -115.09 & 1912.71 & & & 168.82 & & & 411.81 & 431.64 & & 411.81 & & 18.61 \\
\hline Garfield & 38.36 & -118.32 & 246.58 & & & & & & 7.77 & 17.47 & & 7.77 & 8.55 & 4.21 \\
\hline Gilbert & 39.84 & -116.71 & 1540.94 & & & 392.61 & & 540.00 & 538.72 & 398.62 & & 401.45 & & 29.48 \\
\hline Gold Flat & 37.50 & -116.50 & 1791.85 & & & & & & 67.34 & 66.76 & & 67.34 & 67.34 & 3.75 \\
\hline Goldfield & 37.85 & -117.29 & 826.72 & & & & & & & 17.75 & & & & 2.15 \\
\hline Goodsight & 32.50 & -107.33 & 532.20 & 590.00 & 65.00 & & & & & & & 38.85 & & 7.30 \\
\hline $\begin{array}{l}\text { Granite } \\
\text { Springs }\end{array}$ & 40.25 & -118.89 & 2518.64 & & & & & & 103.60 & 109.41 & & 103.60 & 103.60 & 4.17 \\
\hline Groom & 37.31 & -115.86 & 1717.34 & & & & & & 93.24 & 74.32 & & 93.24 & & 5.06 \\
\hline Groom & 37.23 & -115.41 & 2575.13 & & & & & & & 133.60 & & 93.24 & & 4.40 \\
\hline Guano & 42.00 & -119.48 & 2124.41 & & & & & & & 172.02 & & & & 8.10 \\
\hline Harper & 35.06 & -117.33 & 1871.58 & & & & & & & & & 139.86 & & 7.47 \\
\hline High Rock & 42.02 & -119.16 & 194.06 & & & & & & & 13.95 & & 31.08 & & 11.60 \\
\hline Hubbs & 39.76 & -115.37 & 1666.22 & & & 532.16 & 619.98 & 530.00 & 530.95 & 521.93 & & 505.05 & 505.05 & 31.26 \\
\hline Huntoon & 38.11 & -118.58 & 318.05 & & & & & & & 5.39 & & & & 1.69 \\
\hline $\begin{array}{l}\text { Indian } \\
\text { Springs }\end{array}$ & 36.68 & -115.73 & 1719.03 & & & & & & & 168.33 & & & & 9.79 \\
\hline Jakes & 39.30 & -115.27 & 1102.26 & & & 213.14 & & & 163.17 & 155.12 & & 163.17 & 163.17 & 15.56 \\
\hline Kawich & 37.49 & -116.22 & 947.41 & & & & & & 56.98 & 49.12 & & 56.98 & 56.98 & 5.81 \\
\hline Kumiva & 40.43 & -119.12 & 853.07 & & & & & & 38.85 & 45.10 & & 38.85 & 38.85 & 4.74 \\
\hline Labou & 39.23 & -118.27 & 790.86 & & & 35.64 & & & 51.80 & 50.69 & & 51.80 & 51.80 & 6.11 \\
\hline Lahontan & 40.36 & -118.09 & 105613.36 & & & 21906.48 & 30917.97 & 22300.00 & 22004.56 & 23368.63 & & 21859.52 & 23478.78 & 21.29 \\
\hline Laughton & 39.68 & -119.97 & 81.36 & & & & & & 18.13 & 10.87 & & 18.13 & & 19.31 \\
\hline Lemmon & 39.67 & -119.87 & 247.58 & & & & & & 33.67 & 37.94 & & 33.67 & 33.67 & 14.03 \\
\hline Little Fish & 38.84 & -116.42 & 1055.41 & & & & & & & 12.67 & & & & 1.20 \\
\hline $\begin{array}{l}\text { Lunar } \\
\text { Crater } \\
\end{array}$ & 38.66 & -115.98 & 1291.56 & & & & & & & 16.17 & & & & 1.25 \\
\hline Luning & 38.46 & -118.10 & 637.12 & & & & & & & 30.56 & & & & 4.80 \\
\hline Macy & 41.97 & -119.66 & 76.41 & & & & & & & 20.35 & & 23.31 & & 28.57 \\
\hline Madeline & 40.89 & -120.38 & 2167.64 & & & & & 780.00 & 777.00 & 763.23 & & 777.00 & & 35.72 \\
\hline Malheur & 43.44 & -119.11 & 13083.89 & & & & & 2380.00 & 2380.20 & 2432.95 & & 2460.49 & & 18.45 \\
\hline $\begin{array}{l}\text { Manly } \\
\text { Group }\end{array}$ & 36.20 & -117.16 & 51541.38 & & & & & & 4169.88 & 5004.85 & & & & 8.90 \\
\hline Maxey & 38.76 & -114.42 & 1370.13 & & & 210.87 & & & 209.79 & 211.83 & & 209.79 & 209.79 & 15.36 \\
\hline Meinzer & 41.59 & -119.73 & 1870.75 & & & 923.61 & & 920.00 & 919.45 & 992.93 & & 890.96 & 890.96 & 49.34 \\
\hline $\begin{array}{l}\text { Monte } \\
\text { Cristo }\end{array}$ & 38.34 & -117.80 & 720.59 & & & & & & & 14.26 & & & & 1.98 \\
\hline Mormon & 36.84 & -115.40 & 973.54 & & & & & & & 70.35 & & & & 7.23 \\
\hline Newark & 39.38 & -115.82 & 3604.16 & & & 816.84 & 986.44 & 930.00 & 795.13 & 805.90 & & 782.18 & 782.18 & 22.72 \\
\hline Otero & 32.86 & -106.36 & 9556.70 & 12600.00 & 745.00 & & & & & & 409.94 & 466.20 & & 4.58 \\
\hline Pahrump & 36.05 & -115.81 & 3748.99 & & & & & & & 657.73 & & & & 17.54 \\
\hline Papoose & 37.08 & -115.81 & 256.83 & & & & & & & 27.20 & & & & 10.59 \\
\hline Penoyer & 37.74 & -115.79 & 1819.15 & & & & & & & 59.39 & & & & 3.26 \\
\hline Pine & 38.45 & -113.74 & 1898.09 & & & & 922.41 & & 106.19 & 116.43 & & & & 5.86 \\
\hline
\end{tabular}




\begin{tabular}{|c|c|c|c|c|c|c|c|c|c|c|c|c|c|}
\hline Pinos Wells & 34.46 & -105.60 & 589.90 & 560.00 & 82.00 & & & & & 49.11 & 207.20 & & 21.72 \\
\hline Playas & 31.86 & -108.57 & 1135.60 & 1120.00 & 49.00 & & & & & 16.72 & 259.00 & & 12.14 \\
\hline Railroad & 38.65 & -115.67 & 5518.75 & & & 864.43 & 1360.00 & 1359.74 & 980.86 & & 971.25 & 971.25 & 19.65 \\
\hline Reveille & 38.22 & -116.22 & 4346.40 & & & 146.20 & & 106.19 & 103.75 & & 106.19 & 106.19 & 2.62 \\
\hline Rhodes & 38.25 & -118.11 & 520.42 & & & & & 33.67 & 29.66 & & 33.67 & 33.67 & 6.28 \\
\hline Sacramento & 32.46 & -105.66 & 1397.40 & 780.00 & 86.00 & & & & & & & & 6.15 \\
\hline Saline & 36.78 & -117.78 & 1928.51 & & & & & & 83.93 & & & & 4.35 \\
\hline $\begin{array}{l}\text { San } \\
\text { Agustin }\end{array}$ & 33.85 & -108.15 & 3046.90 & 3880.00 & 786.00 & & & & & 513.47 & 1129.24 & & 26.96 \\
\hline Snyder & 38.84 & -116.07 & 163.65 & & & & & & 38.98 & & & & 23.82 \\
\hline Spring & 39.45 & -114.47 & 2949.98 & & & 617.85 & 870.00 & 870.24 & 640.32 & & 603.47 & 603.47 & 23.76 \\
\hline Stonewall & 37.63 & -116.94 & 938.60 & & & & & & 49.80 & & & & 5.31 \\
\hline Surprise & 41.35 & -119.98 & 3840.91 & & & 1477.95 & 1310.00 & 1310.53 & 1475.66 & & 1471.11 & 1484.84 & 37.01 \\
\hline Teel & 38.13 & -118.37 & 810.54 & & & & & & 42.30 & & & & 5.22 \\
\hline Thompson & 34.92 & -118.02 & 9115.90 & & & & 950.00 & 950.53 & & & 556.85 & & 8.99 \\
\hline Toiyabe & 39.10 & -117.02 & 3411.50 & & & 421.96 & 650.00 & 650.09 & 573.98 & & 525.77 & 525.77 & 16.35 \\
\hline Tonopah & 38.42 & -117.51 & 5294.27 & & & 277.56 & & 233.10 & 264.91 & & 233.10 & 233.10 & 4.69 \\
\hline Trinity & 33.55 & -106.56 & 4524.50 & 4240.00 & 207.00 & & & & & 134.57 & 199.43 & & 3.69 \\
\hline UN-GB1 & 35.76 & -116.83 & 43.73 & & & & & & 3.73 & & & & 8.53 \\
\hline UN -GB2 & 35.70 & -116.77 & 360.86 & & & & & & 2.72 & & & & 0.75 \\
\hline UN -GB3 & 37.14 & -117.22 & 249.07 & & & & & & 4.34 & & & & 1.74 \\
\hline UN-GB4 & 37.17 & -117.83 & 1540.52 & & & & & & 6.55 & & & & 0.43 \\
\hline UN-GB5 & 36.76 & -117.53 & 162.92 & & & & & & 6.25 & & & & 3.84 \\
\hline UN-GB6 & 35.55 & -116.69 & 402.92 & & & & & & 4.78 & & & & 1.19 \\
\hline UN-GB7 & 35.44 & -113.80 & 3674.90 & & & & & & & 300.82 & & & 8.19 \\
\hline UN-SW1 & 34.14 & $\begin{array}{l}-107.61 \\
\end{array}$ & 882.90 & & & & & & & 49.73 & & & 5.63 \\
\hline UN-SW10 & 33.47 & -102.49 & 936.20 & & & & & & & 20.46 & & & 2.19 \\
\hline UN-SW11 & 33.76 & -102.52 & 702.40 & & & & & & & 54.71 & & & 7.79 \\
\hline UN-SW12 & 33.98 & -102.55 & 200.50 & & & & & & & 19.16 & & & 9.56 \\
\hline UN-SW13 & 33.89 & -102.98 & 1653.40 & & & & & & & 51.41 & & & 3.11 \\
\hline UN-SW14 & 33.68 & -103.68 & 82.80 & & & & & & & 15.54 & & & 18.77 \\
\hline UN-SW15 & 34.85 & -103.99 & 49.30 & & & & & & & 14.32 & & & 29.05 \\
\hline UN-SW2 & 31.77 & -102.88 & 2437.20 & & & & & & & 19.49 & & & 0.80 \\
\hline UN-SW3 & 31.50 & -102.67 & 340.80 & & & & & & & 15.02 & & & 4.41 \\
\hline UN-SW4 & 31.47 & -102.52 & 696.00 & & & & & & & 17.44 & & & 2.51 \\
\hline UN-SW5 & 31.68 & -101.88 & 202.60 & & & & & & & 14.15 & & & 6.99 \\
\hline UN-SW6 & 32.39 & -102.66 & 103.70 & & & & & & & 32.83 & & & 31.66 \\
\hline UN-SW7 & 32.91 & -102.29 & 421.70 & & & & & & & 35.39 & & & 8.39 \\
\hline UN-SW8 & 33.13 & 223.12 & 222.00 & & & & & & & 47.14 & & & 21.23 \\
\hline UN-SW9 & 33.44 & -102.07 & 688.90 & & & & & & & 19.94 & & & 2.89 \\
\hline Waring & 40.00 & -114.65 & 8566.76 & & & 1375.87 & 2520.00 & 1331.25 & 1686.23 & & 1401.18 & 1401.18 & 18.90 \\
\hline Warner & 42.40 & -119.90 & 4804.82 & & & 1331.27 & 1250.00 & 1250.97 & 1202.50 & & 1307.94 & & 26.40 \\
\hline Yahoo & 39.47 & -116.09 & 44.62 & & & & & 5.18 & 6.97 & & 5.18 & 5.18 & 12.61 \\
\hline Yucca & 37.09 & -116.08 & 777.53 & & & & & & 12.39 & & & & 1.59 \\
\hline
\end{tabular}




\begin{tabular}{|c|c|}
\hline \multicolumn{2}{|c|}{$\begin{array}{c}\text { Normalized Area (\%) } \\
\text { Distribution }\end{array}$} \\
\hline Median & 9.20 \\
\hline Q1 & 4.62 \\
\hline Q3 & 19.17 \\
\hline Max & 49.34 \\
\hline \multicolumn{2}{|c|}{$\begin{array}{l}\text { Adjusted Normalized Are } \\
\text { (\%) Distribution }\end{array}$} \\
\hline Median & 7.30 \\
\hline Q1 & 4.32 \\
\hline Q3 & 13.62 \\
\hline Max & 38.75 \\
\hline \multicolumn{2}{|c|}{$\begin{array}{c}\text { South Great Basin (\%) } \\
\text { Distribution }\end{array}$} \\
\hline Median & 5.06 \\
\hline Q1 & 2.62 \\
\hline Q3 & 8.53 \\
\hline Max & 23.82 \\
\hline
\end{tabular}


Table DR2 -Area of modern lakes $\left(>\mathbf{1} \mathbf{k m}^{2}\right)$ found in terminal watersheds. Data derived from the

HydroSHEDS/HydroLAKES/HydroBASINS database (Lehner et al., 2008; Lehner and Grill, 2013; Messager et al., 2016) intended to represent maximum possible sizes by including seasonal playa lakes.

\begin{tabular}{|c|c|c|c|c|}
\hline $\begin{array}{l}\text { Lake } \\
\text { Name }\end{array}$ & $\begin{array}{c}\text { Basin } \\
\text { Area }\end{array}$ & $\begin{array}{c}\text { Total } \\
\text { Lake Area }\end{array}$ & $\begin{array}{c}\text { Normalized } \\
\text { Area (\%) }\end{array}$ & Notes \\
\hline Alkali & 1375.20 & 14.97 & 1.09 & 3 unnamed seasonal playa lakes \\
\hline Alvord & 7031.36 & 5.49 & 0.08 & Seasonal playa lake \\
\hline Bonneville & 134131.13 & 8923.51 & 6.65 & Maximum size: Great Salt Lake, Bonneville Salt Flats, Bear Lake and other playa lakes \\
\hline Chewaucan & 3385.35 & 285.86 & 8.44 & Lake Abert and Summer Lake \\
\hline Clover & 2665.56 & 5.13 & 0.19 & Playa Lake \\
\hline Fort Rock & 6403.89 & 8.24 & 0.13 & Seasonal playa Lake \\
\hline Franklin & 3345.89 & 13.17 & 0.39 & 3 playa/marsh lakes \\
\hline Lahontan & 105613.36 & 954.70 & 0.90 & Pyramid and Walker Lakes (historic areas) plus playa lakes \\
\hline Malheur & 13083.89 & 422.28 & 3.23 & 2 playa lakes \\
\hline $\begin{array}{l}\text { Manly } \\
\text { Group }\end{array}$ & 51541.38 & 238.52 & 0.46 & $\begin{array}{l}\text { Includes area of Mono Lake (Pleistocene Lake Russell) and seasonal playa lakes in all following } \\
\text { sub-basins: Owens, Searles, Panamint, Manly }\end{array}$ \\
\hline Meinzer & 1870.75 & 56.33 & 3.01 & Numerous small seasonal playa lakes \\
\hline Spring & 2949.98 & 4.07 & 0.14 & Playa lake \\
\hline Surprise & 3840.91 & 255.13 & 6.64 & 3 seasonal playa lakes \\
\hline Warner & 4804.82 & 130.15 & 2.71 & Numerous small seasonal playa lakes \\
\hline & & \multicolumn{2}{|c|}{$\begin{array}{c}\text { Area Normalized (\%) } \\
\text { Distribution }\end{array}$} & \\
\hline & & Median & 1.00 & \\
\hline & & IQR1 & 0.24 & \\
\hline & & IQR3 & 3.17 & \\
\hline & & Max & 8.44 & \\
\hline
\end{tabular}


Table DR3 - Compilation of mid-Pliocene (early Piacenzian, 2.9 to 3.3 Ma) lake deposits. P2014 - Pound et al. (2014). We consider all continuous formations that span the Piacenzian in Macrostrat. Pliocene lake areas are only paired to basin areas when it is clear that the lake was terminal, does not span multiple modern watersheds over large drainage divides, and have not been greatly influenced by tectonic drainage reconfiguration.

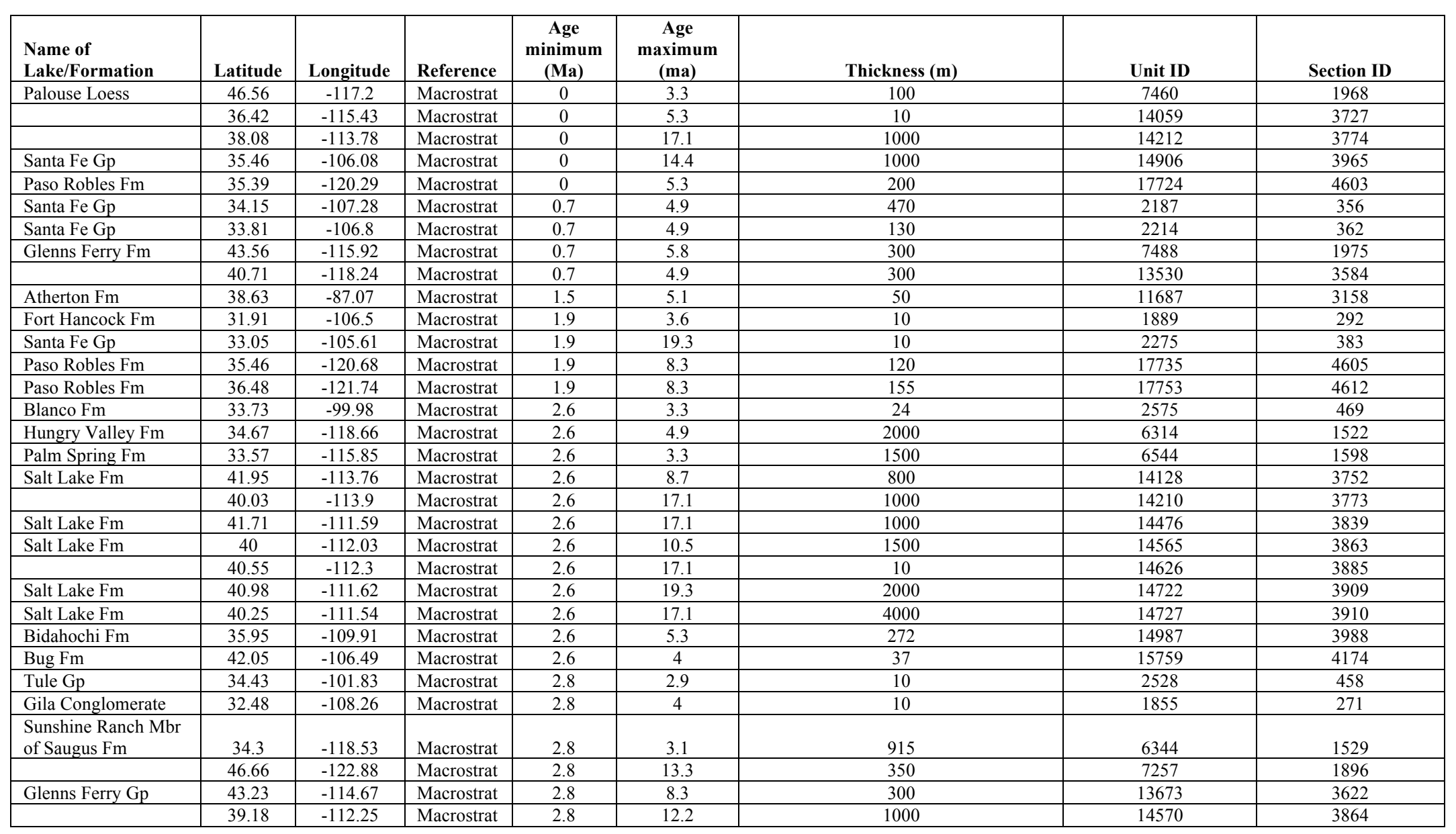




\begin{tabular}{|c|c|c|c|c|c|c|c|c|c|}
\hline Thousand Creek Beds & 41.46 & -119.04 & Macrostrat & 2.9 & 8.3 & & 13454 & & 3543 \\
\hline $\begin{array}{l}\text { Name of } \\
\text { Lake/Formation }\end{array}$ & Latitude & Longitude & Reference & $\begin{array}{c}\text { Basin } \\
\text { Area } \\
\left(\mathrm{km}^{2}\right)\end{array}$ & Basin Area Notes & $\begin{array}{c}\text { Outcrop or } \\
\text { Lake Area } \\
\left(\mathbf{k m}^{2}\right)\end{array}$ & $\begin{array}{l}\text { Normalized } \\
\text { Area }(\%)\end{array}$ & $\begin{array}{c}\text { Age } \\
\text { minimum } \\
\text { (Ma) }\end{array}$ & $\underset{\substack{\text { Age } \\
\text { maximum }}}{(\mathbf{m a})}$ \\
\hline Tule Lake & 41.98 & -122.05 & P2014 & & Not terminal? & 6291.45 & & 2.6 & 3 \\
\hline $\begin{array}{l}\text { Rhodes-Clayton-Fish } \\
\text { Valleys, NV }\end{array}$ & 38.00 & -118.00 & P2014 & & Watershed unclear & 10800 & & 2.6 & 3.4 \\
\hline Owens Lake & 36.55 & -118.00 & P2014 & & Larger Manly Basin & 1500 & & 2 & 3 \\
\hline Lake Manly & 36.55 & -117.05 & P2014 & & Larger Manly Basin & 1300 & & 2 & 3 \\
\hline Panamint Lake & 35.95 & -117.20 & P2014 & & Larger Manly Basin & 276 & & 2 & 3 \\
\hline China-Scarles Lake & 35.55 & -117.40 & P2014 & & Larger Manly Basin & 800 & & 2 & 3 \\
\hline Kochn Lake_1 & 35.18 & -117.85 & P2014 & & Larger Manly Basin & 40 & & 2 & 3 \\
\hline Kochn Lake 2 & 35.15 & -117.40 & P2014 & & Larger Manly Basin & 12.5 & & 2 & 3 \\
\hline Kochn Lake 3 & 35.10 & -117.10 & P2014 & & Larger Manly Basin & 16 & & 2 & 3 \\
\hline Lake Russell & 38.00 & -119.00 & P2014 & & $\begin{array}{l}\text { Mono and Lake Russell listed } \\
\text { separately by P2014 }\end{array}$ & 2800 & & 2 & 2.8 \\
\hline Mono Lake & 38.00 & -118.55 & P2014 & & $\begin{array}{l}\text { Mono and Lake Russell listed } \\
\text { separately by P2014 }\end{array}$ & 1125 & & 2 & 3 \\
\hline $\begin{array}{l}\text { All Manly Basin with } \\
\text { Lake Russell Area }\end{array}$ & & & P2014 & 51541 & & 6744.5 & 13.09 & & \\
\hline Harper 2 & 34.65 & -117.90 & P2014 & & Watershed unclear & 4 & & 2 & 3 \\
\hline Harper 3 & 34.70 & -117.80 & P2014 & 750 & Assumed separate from Harper 4 & 60 & 8.00 & 2 & 3 \\
\hline Harper 4 & 34.45 & -117.50 & P2014 & 1027 & Assumed separate from Harper 3 & 10 & 0.97 & 2 & 3 \\
\hline South_Mojave & 34.30 & -117.00 & P2014 & 11237 & & 4 & 0.04 & $\frac{2}{2}$ & 3 \\
\hline Lake Tecopa & 35.75 & -116.25 & P2014 & 14129 & & 112 & 0.79 & 2 & 3 \\
\hline Lake Mojave & 35.05 & -116.10 & P2014 & 8219 & $\begin{array}{l}\text { Assume that Mojave separate from } \\
\text { Manly group during Pliocene }\end{array}$ & 120 & 1.46 & 2 & 3 \\
\hline Lake Manix & 34.85 & -116.40 & P2014 & 1041 & $\begin{array}{l}\text { Assume that Manix separate from } \\
\text { Manly group during Pliocene }\end{array}$ & 50 & 4.80 & 2 & 3 \\
\hline Bristol Lake & 34.30 & -115.65 & P2014 & 1285 & & 84 & 6.54 & 2 & 3 \\
\hline Cadiz Lake & 34.15 & -115.40 & P2014 & 967 & & 55 & 5.69 & 2 & 3 \\
\hline Danby Lake & 34.05 & -115.15 & P2014 & 1120 & & 72 & 6.43 & 2 & 3 \\
\hline Rita Blanca & 35.72 & -102.39 & P2014 & 1738 & & 54.39 & 3.13 & 3 & 3.6 \\
\hline Hueco Bolson, TX & 30.90 & -105.30 & P2014 & & Not terminal? & 5780 & & 1.8 & 4.8 \\
\hline & & & & & & \multicolumn{2}{|c|}{$\begin{array}{c}\text { Normalized Area (\%) } \\
\text { Distribution }\end{array}$} & & \\
\hline & & & & & & Median & 4.80 & & \\
\hline & & & & & & Q1 & 1.22 & & \\
\hline & & & & & & Q3 & 6.48 & & \\
\hline
\end{tabular}


Table DR4 - Climate models used in this study.

\begin{tabular}{|c|c|c|c|}
\hline Model & $\begin{array}{l}\text { Organization, } \\
\text { Country }\end{array}$ & $\begin{array}{l}\text { Atmospheric } \\
\text { Resolution } \\
\text { (\#lat x lon x levels) }\end{array}$ & References \\
\hline \multicolumn{4}{|c|}{ PMIP3 LGM Ensemble } \\
\hline CNRM-CM5 & $\begin{array}{l}\text { CNRM-CERFACS, } \\
\text { France }\end{array}$ & $256 \times 128 \times$ L31 & $\begin{array}{l}\text { Voldoire et al. } \\
\text { (2013) }\end{array}$ \\
\hline COSMOS-ASO & $\begin{array}{l}\text { Freie Universität } \\
\text { Berlin, Germany }\end{array}$ & $96 \times 48$ x L19 & Zhou et al. (2014) \\
\hline CCSM4 & $\begin{array}{l}\text { National Center for } \\
\text { Atmospheric } \\
\text { Research, USA }\end{array}$ & $288 \times 192$ x L26 & $\begin{array}{l}\text { Gent et al. (2011); } \\
\text { Brady et al. (2013) }\end{array}$ \\
\hline MRI-CGCM3 & $\begin{array}{l}\text { Meteorological } \\
\text { Research Institute, } \\
\text { Japan }\end{array}$ & $320 \times 160 \times$ L48 & $\begin{array}{l}\text { Yukimoto et al. } \\
\text { (2012) }\end{array}$ \\
\hline IPSL-CM5A-L & $\begin{array}{l}\text { Institute Pierre } \\
\text { Simon Laplace, } \\
\text { France }\end{array}$ & $96 \times 95 \times$ x L39 & $\begin{array}{l}\text { Kageyama et al. } \\
\text { (2013); Dufresne et } \\
\text { al. (2013) }\end{array}$ \\
\hline MPI-ESM-P & $\begin{array}{l}\text { Max Planck Institute } \\
\text { for Meteorology, } \\
\text { Germany }\end{array}$ & $196 \times 98 \times$ x47 & \\
\hline MIROC-ESM & $\begin{array}{l}\text { Model for } \\
\text { Interdisciplinary } \\
\text { Research on } \\
\text { Climate, Japan }\end{array}$ & $128 \times 64$ x L80 & $\begin{array}{l}\text { Sueyoshi et al. } \\
\text { (2013) }\end{array}$ \\
\hline \multicolumn{4}{|c|}{ PlioMIP (Experiment 2) Ensemble } \\
\hline CCSM4 & $\begin{array}{l}\text { National Center for } \\
\text { Atmospheric } \\
\text { Research, USA }\end{array}$ & $288 \times 192 \times$ L 26 & $\begin{array}{l}\text { Rosenbloom et al. } \\
\text { (2013) }\end{array}$ \\
\hline MRI-CGCM 2.3 & $\begin{array}{l}\text { Meteorological } \\
\text { Research Institute } \\
\text { and University of } \\
\text { Tsukuba, Japan }\end{array}$ & $128 \times 64$ x L30 & $\begin{array}{l}\text { Kamae and Ueda } \\
\text { (2012) }\end{array}$ \\
\hline NorESM-L & $\begin{array}{l}\text { Bjerknes Centre for } \\
\text { Climate Research, } \\
\text { Norway }\end{array}$ & $96 \times 48 \times$ x 26 & $\begin{array}{l}\text { Zhang and Yan } \\
\text { (2012); Zhang et al. } \\
\text { (2012) }\end{array}$ \\
\hline HadCM3 & $\begin{array}{l}\text { Hadley Centre for } \\
\text { Climate Prediction } \\
\text { and Research/Met } \\
\text { Office, UK }\end{array}$ & $96 \times 73 \times$ L19 & Bragg et al. (2012) \\
\hline IPSL-CM5A & $\begin{array}{l}\text { Institute Pierre } \\
\text { Simon Laplace, } \\
\text { France }\end{array}$ & 96x95 x L39 & $\begin{array}{l}\text { Contoux et al. } \\
\text { (2012) }\end{array}$ \\
\hline COSMOS & $\begin{array}{l}\text { Alfred Wegener } \\
\text { Institute, Germany }\end{array}$ & $96 \times 48 \times$ L 19 & $\begin{array}{l}\text { Stepanek and } \\
\text { Lohmann (2012) }\end{array}$ \\
\hline
\end{tabular}


Table DR5 - Regional fitted Budyko parameters

\begin{tabular}{lcc}
\hline Model & LGM $\boldsymbol{\omega}$ value & PI Control $\boldsymbol{\omega}$ value \\
\hline CNRM-CM5 & 1.82 & 2.08 \\
COSMOS-ASO & 1.98 & 2.30 \\
CCSM4 & 1.98 & 2.44 \\
MRI-CGCM3 & 1.97 & 2.57 \\
IPSL-CM5A-L & 1.69 & 2.21 \\
MPI-ESM-P & 1.82 & 2.31 \\
MIROC-ESM & 1.76 & 2.60 \\
\hline & Pliocene $\boldsymbol{\omega}$ value & PI Control $\boldsymbol{\omega}$ value \\
CCSM4 & 2.25 & 2.60 \\
MRI-CGCM 2.3 & 2.31 & 2.27 \\
NorESM-L & 1.98 & 2.18 \\
HadCM3 & 1.99 & 1.90 \\
IPSL-CM5A & 2.04 & 2.24 \\
COSMOS & 2.64 & 2.51 \\
\hline
\end{tabular}




\section{Data Repository References}

Adam, D.P., Bradbury, J.P., Rieck, H.J. and Sarna-Wojcicki, A.M., 1990, Environmental changes in the Tule Lake Basin, Siskiyou and Modoc Counties, California, from 3 to 2 Million years before present, USGS Bulletin 1933, $13 \mathrm{p}$.

Allen, B.D., 2005, Ice age lakes in New Mexico: New Mexico's ice ages New Mexico Museum of Natural History and Science Bulletin, no. 28, p. 107-114.

Braconnot, P., Harrison, S.P., Kageyama, M., Bartlein, P.J., Masson-Delmotte, V., Abe-

Ouchi, A., Otto-Bliesner, B., and Zhao, Y., 2012, Evaluation of climate models using palaeoclimatic data: Nature Climate Change, v. 2, no. 6, p. 417-424.

Brady, E.C., Otto Bliesner, B.L., Kay, J.E., and Rosenbloom, N., 2013, Sensitivity to Glacial Forcing in the CCSM4: Journal of Climate, v. 26, no. 6, p. 1901-1925.

Bony, S., and Emanuel, K. A., 2001, A parameterization of the cloudiness associated with cumulus convection; evaluation using TOGA COARE data: Journal of the Atmospheric Sciences, v. 51, no. 21, p. 3158-3183

Bragg, F.J., Lunt, D.J., and Haywood, A.M., 2012, Mid-Pliocene climate modelled using the UK Hadley Centre Model: PlioMIP Experiments 1 and 2: Geoscientific Model Development, v. 5, no. 5, p. 1109-1125.

Colgan, J.P., Dumitru, T.A., McWilliams, M., Miller, E.L., 2006, Timing of Cenozoic volcanism and Basin and Range extension in northwestern Nevada: New constraints from the northern Pine Forest Range: Bulletin of the Geological Society of America, v. 118, no. 1-2, p. 126-139.

Contoux, C., Ramstein, G., and Jost, A., 2012, Modelling the mid-Pliocene Warm Period climate with the IPSL coupled model and its atmospheric component LMDZ5A: 
Geoscientific Model Development, v. 5, no. 3, p. 903-917.

Dufresne, J.L., Foujols, M.A., Denvil, S., Caubel, A., Marti, O., Aumont, O., Balkanski, Y., Bekki, S., Bellenger, H., Benshila, R., Bony, S., Bopp, L., Braconnot, P., Brockmann, P., et al., 2013, Climate change projections using the IPSL-CM5 Earth System Model: from CMIP3 to CMIP5: Climate dynamics, v. 40, no. 9-10, p. $2123-2165$.

Gent, P., Gent, P.R., Danabasoglu, G., Donner, L.J., Holland, M.M., Hunke, E.C., Jayne, S.R., Lawrence, D.M., Neale, R.B., Rasch, P.J., Vertenstein, M., Worley, P.H., Yang, Z.-L., and Zhang, M., 2011, The community climate system model version 4: Journal of Climate, v. 24, no. 19, p. 4973-4991.

Gillespie, A., 2014, Land Surface Emissivity, in Njoku, E.G., ed., Encyclopedia of Remote Sensing: Springer Science+Business Media New York, v. XXV, p. 303311

Grayson, D., 2011, The Great Basin: a natural prehistory: University of California Press, $432 \mathrm{p}$.

Haywood, A., Dowsett, H., and Otto-Bliesner, B., 2011, Pliocene Model Intercomparison Project (PlioMIP): experimental design and boundary conditions (experiment 2): Geoscientific Model Development, v. 4, p. 571-577. Haywood, A.M., Hill, D.J., Dolan, A.M., Otto-Bliesner, B.L., Bragg, F., Chan, W.-L., Chandler, M.A., Contoux, C., Dowsett, H.J., Jost, A., Kamae, Y., Lohmann, G., Lunt, D.J., Abe-Ouchi, A., Pickering, S.J., Ramstein, G., Rosenbloom, N.A., Salzmann, U., Sohl, L., Stepanek, C., Ueda, H., Yan, Q., and Zhang, Z., 2013, Largescale features of Pliocene climate: results from the Pliocene Model Intercomparison 
Project: Climate of the Past, v. 9, p. 191-209.

Ibarra, D.E., Egger, A.E., Weaver, K.L., Harris, C.R., and Maher, K., 2014, Rise and fall of late Pleistocene pluvial lakes in response to reduced evaporation and precipitation: Evidence from Lake Surprise, California: Bulletin of the Geological Society of America, v. 126, no. 11-12, p. 1387-1415.

Kageyama, M., Braconnot, P., Bopp, L., Caubel, A., Foujols, M.-A., Guilyardi, E., Khodri, M., Lloyd, J., Lombard, F., Mariotti, V., Marti, O., Roy, T., and Woillez, M.-N., 2013, Mid-Holocene and Last Glacial Maximum climate simulations with the IPSL model_-part I: comparing IPSL_CM5A to IPSL_CM4: Climate dynamics, v. 40, no. 9-10, p. 2447-2468.

Kamae, Y., and Ueda, H., 2012, Mid-Pliocene global climate simulation with MRICGCM2.3: set-up and initial results of PlioMIP Experiments 1 and 2: Geoscientific Model Development, v. 5, no. 3, p. 793-808.

Knott, J.R., Machette, M.N., Klinger, R.E., Sarna-Wojcicki, A.M., Liddicoat, J.C., Tinsley III, J.C., David, B.T., Ebbs, V.M., 2008, Reconstructing late Pliocene to middle Pleistocene Death Valley lakes and river systems as a test of Pupfish (Cyprinodontidae) dispersal hypotheses: The Geological Society of America Special Paper v. 439, p. 1-26.

Koster, R.D., Fekete, B.M., Huffman, G.J., and Stackhouse, P.W., 2006, Revisiting a hydrological analysis framework with International Satellite Land Surface Climatology Project Initiative 2 rainfall, net radiation, and runoff fields: Journal of Geophysical Research, v. 111, no. 22, p. D22S05.

Lehner, B., and Grill, G., 2013, Global river hydrography and network routing: baseline 
data and new approaches to study the world\&apos;s large river systems (H.

Habersack, D. Walling, \& D. Haspel, Eds.): Hydrological Processes, v. 27, no. 15, p. 2171-2186.

Lehner, B., Verdin, K., and Jarvis, A., 2008, New Global Hydrography Derived From Spaceborne Elevation Data: Eos, Transactions American Geophysical Union, v. 89 , no. 10 , p. $93-94$.

Linacre, E.T., 1977, A simple formula for estimating evaporation rates in various climates, using temperature data alone: Agricultural meteorology, v. 18, no. 6, p. $409-424$.

Messager, M.L., Lehner, B., Grill, G., Nedeva, I., and Schmitt, O., 2016, Estimating the volume and age of water stored in global lakes using a geo-statistical approach.: Nature Communications, v. 7, p. 13603.

Mifflin, M.D., and Wheat, M.M., 1979, Mifflin: Pluvial Lakes and Estimated Pluvial Climates of Nevada: Nevada Bureau of Mines and Geology Bulletin no. 94, 57 p. Milly, P.C.D., and Dunne, K.A., 2016, Potential evapotranspiration and continental drying: Nature Climate Change, v. 6, p. 946-949.

Morcrette, J.-J., 1991, Radiation and cloud radiative properties in the European Centre for Medium Range Weather Forecasts forecasting system: Journal of Geophysical Research: Atmospheres, v. 96, no. D5, p. 9121-9132

Munroe, J.S., and Laabs, B.J.C., 2013, Latest Pleistocene history of pluvial Lake Franklin, northeastern Nevada, USA: Geological Society of America Bulletin, v. 125 , no. $3-4$, p. $322-342$.

Orme, A.R., 2008, Pleistocene pluvial lakes of the American West: a short history of 
research: Geological Society, London, Special Publications, v. 301, no. 1, p. 5178.

Phillips, F.M., 2008, Geological and hydrological history of the paleo-Owens River drainage since the late Miocene: The Geological Society of America Special Paper v. 439, p. 115-150.

Reheis, M.C., 1999, Extent of Pleistocene lakes in the western Great Basin: U.S. Geological Survey Miscellaneous Field Studies Map MF-2323, scale 1:800,000, 1 sheet.

Reheis, M.C., Sarna-Wojcicki, A.M., Reynolds, R.L., Repenning, C.A., Mifflin, M.D., 2002, Pliocene to middle Pleistocene lakes in the Western Great Basin: Ages and connections, in Hershler, R., Madsen, D.B., Currey, D.R., eds., Great basin aquatic systems history. Smithsonian Institution Press, Washington D.C., p. 53108.

Reheis, M.C., Adams, K.D., Oviatt, C.G., and Bacon, S.N., 2014, Pluvial lakes in the Great Basin of the western United States-a view from the outcrop: Quaternary Science Reviews, v. 97, p. 33-57.

Roderick, M.L., Sun, F., Lim, W.H., and Farquhar, G.D., 2014, A general framework for understanding the response of the water cycle to global warming over land and ocean: Hydrology and Earth System Sciences, v. 18, no. 5, p. 1575-1589.

Roderick, M.L., Greve, P., Farquhar, G.D., 2015, On the assessment of aridity with changes in atmospheric $\mathrm{CO}_{2}$ : Water Resources Research, v. 51, no. 7, p. 54505463.

Rosenbloom, N.A., Otto-Bliesner, B.L., Brady, E.C., and Lawrence, P.J., 2012, 
Simulating the mid-Pliocene Warm Period with the CCSM4 model: Geoscientific Model Development Discussions, v. 5, p. 4269-4303.

Scheff, J., and Frierson, D. M. W., 2014, Scaling Potential Evapotranspiration with Greenhouse Warming: Journal of Climate, v. 27, no. 4, p. 1539-1558

Smith, G.R., 1981, Late Cenozoic Freshwater Fishes of North America: Annual Review of Ecology and Systematics, v. 12, p. 163-193.

Soller, D.R., Reheis, M.C., Garrity, C.P., and Van Sistine, D.R., 2009, Map database for surficial materials in the conterminous United States: U.S. Geological Survey Data Series 425, scale 1: 5,000,000.

Stepanek, C., and Lohmann, G., 2012, Modelling mid-Pliocene climate with COSMOS: Geoscientific Model Development, v. 5, no. 5, p. 1221-1243.

Sueyoshi, T., Ohgaito, R., Yamamoto, A., Chikamoto, M.O., Hajima, T., Okajima, H., Yoshimori, M., Abe, M., O'ishi, R., Saito, F., Watanabe, S., Kawamiya, M., and Abe-Ouchi, A., 2013, Set-up of the PMIP3 paleoclimate experiments conducted using an Earth system model, MIROC-ESM: Geoscientific Model Development, v. 6 , no. 3 , p. $819-836$.

Thompson, R.S., 1992, Palynological data from a 989-FT (301-M) core of Pliocene and Early Pleistocene sediments from Bruneau, Idaho, U.S. Geological Survey Open File Report 92-713, 28 p.

Voldoire, A., Sanchez-Gomez, E., Mélia, D.S.Y., Decharme, B., Cassou, C., Sénési, S., Valcke, S., Beau, I., Alias, A., Chevallier, M., Déqué, M., Deshayes, J., Douville, H., Fernandez, E., et al., 2013, The CNRM-CM5.1 global climate model: description and basic evaluation: Climate dynamics, v. 40, no. 9-10, p. 2091- 
2121.

Williams, T.R., and Bedinger, M.S., 1984, Selected geologic and hydrologic characteristics of the Basin and Range Province, western United States; Pleistocene lakes and marshes: IMAP 1522-D, scale 1:2,500,000, 1 sheet.

Yukimoto, S., Adachi, Y., Hosaka, M., Sakami, T., Yoshimura, H., Hirabara, M., Tanaka, T.Y., Shindo, E., Tsujino, H., Deushi, M., Mizuta, R., Yabu, S., Obata, A., Nakano, H., et al., 2012, A New Global Climate Model of the Meteorological Research Institute: MRI-CGCM3-Model Description and Basic Performance: Journal of the Meteorological Society of Japan, v. 90A, no. 0, p. 23-64.

Zhang, Z., and Yan, Q., 2012, Pre-industrial and mid-Pliocene simulations with NorESM-L: AGCM simulations: Geoscientific Model Development, v. 5, no. 4, p. $1033-1043$.

Zhang, Z.S., Nisancioglu, K., Bentsen, M., Tjiputra, J., Bethke, I., Yan, Q., Risebrobakken, B., Andersson, C., and Jansen, E., 2012, Pre-industrial and midPliocene simulations with NorESM-L: Geoscientific Model Development, v. 5, no. 2 , p. $523-533$.

Zhou, T., Chen, X., Dong, L., Wu, B., Man, W., Zhang, L., Lin, R., Yao, J., Song, F., and Zhao, C., 2014, Chinese contribution to CMIP5: An overview of five Chinese models' performances: Journal of Meteorological Research, v. 28, no. 4, p. 481509. 


\section{APPENDIX C \\ Supplemental Tables for Chapter 3}

The following tables are included in the appended excel file

"Ibarra_Chapter3_Tables.xlsx" and have been published as supplementary files with the original publications (Ibarra et al., 2016; Ibarra et al., 2017).

Chapter 3.1 (Ibarra et al., 2016, Geochemica et Cosmochimica Acta)

Table A1. Summary of compiled datasets

Table A2. $\mathrm{SiO}_{2}$ (aq) concentration-runoff results

Table A3. $\mathrm{Mg}^{2+}$ concentration-runoff results

Table A4. $\mathrm{Ca}^{2+}$ concentration-runoff results

Table A5. Na* concentration-runoff results

Table A6. $\mathrm{HCO}_{3}{ }^{-}$concentration-runoff results

Table A7. Catio-equivalent concentration-runoff results

Table A8. TDS concentration-runoff results

Table A9. Flux weighted concentrations and $D w$ values

Chapter 3.2 (Ibarra et al., 2017, Acta Geochemica)

Table S1. Average concentraiton-runoff pair and full concentration-runoff fitted parameters. 